
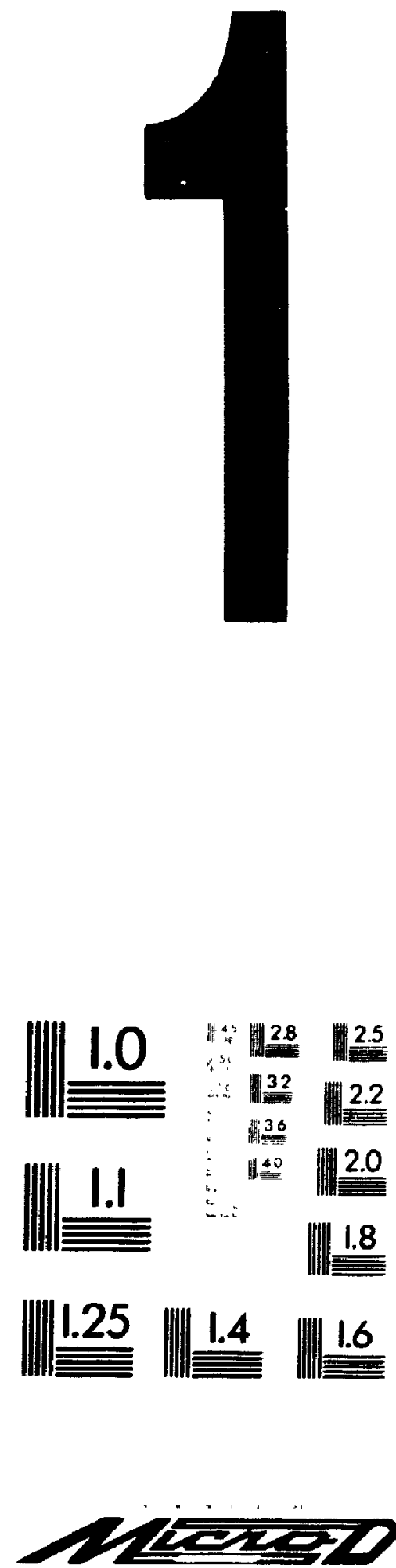
National Library

of Canada

Canadian Theses Service

Ottawa, Canada

KIA ONA
Bibliotheque nationale

du Canada

Service des thèses canadiennes

\section{NOTICE}

The quality of this microform is heavily dependent upon the quality of the original thesis submitted for microlilming. Every effort has been made to ensure the highest quality of reproduction possible.

If pages are missing. contact the university which granted the degree.

Some pages may have indistinct print especially if the original pages were typed with a poor typewriter ribbon or if the university sent us an inferior pholocopy.

Reproduction in full or in part of this microform is governed by the Canadian Copyright Act, R.S.C. 1970, C. C-30, and subsequent amendments.

\begin{abstract}
AVIS
La qualité de cette microforme dépend grandement de la qualité de la thèse soumise au microfilmage. Nous avons tout fait pour assurer une qualité supérieure de reproduc tion.

S'il manque des pages, veuillez communiquer avec l'université qui à conféré le grade.

La qualité d'impression de certaines pages peut lasser à désirer, surtout si les pages originales ont élé dactylogra. phiées à laide d'un nuban usé ou si liuniversité nous a fail parvenir une photocopie de qualité inférieure.
\end{abstract}

La reproduction, méme partielle, de cette microforme est soumise a la Loi canadienne sur le droit dauteur. SHC 1970, c. C-30, et ses amendements subséquents 


\title{
GEOLOGY, GEOCHEMISTRY, AGE AND TECTONIC SETTING Of THE GORE-Gambella PLUTONic ROCKS, WESTERN ETHIOPIA
}

\author{
by \\ Teklewold Ayalew Alemayehu, B.Sc., M.Sc. \\ A thesis submitted to \\ the Faculty of Graduate Studies and Research \\ in partial fulfilment of \\ the requirements for the degree of \\ Doctor of Philosophy \\ Department of Earth Sciences \\ Carleton University \\ Ottawa, Ontario \\ December, 1988
}

copyright

1988, Teklewold Ayalew Alemayehu 
The author has granted an irrevocable nonexclusive licence allowing the National Libr..'y of Canada to reproduce, loan, distribute or sell copies of his/her thesis by any means and in any form or format, making this thesis available to interested persons.

The author retains ownership of the copyright in his/her thesis. Neititer the thesis nor substantial extracts from it may be printed or otherwise reproduced without his/her permission.
L'auteur a accordé une licence irrévocable et non exclusive permettant à la Bibliothèque nationale du Canada de reproduire, preter, distribuer ou vendre des copies de sa thèse de quelque manière et sous quelque forme que ce soit pour mettre des exemplaires de cette thèse à la disposition des personnes intéressées.

L'auteur conserve la propriété du droit d'auteur qui protège sa thèse. Ni la thèse ni des extraits substantiels de celle-ci ne doivent être imprimés ou autrement reproduits sans son autorisation.

$$
\text { ISBN } \quad 0-315-51137-0
$$


The undersigned hereby recommend to

The Faculty of Graduate Studies and Research

acceptance of the thesis, Geology, Geochemistry, Age and Tectonic setting

of the Gore-Gambella plutonic rocks, Western Ethiopia, submitted by

Teklewold Ayalew Alemaychu, B.Sc., M.Sc.

in partial fulfilment of the requirements

for the degree of Doctor of Philosophy

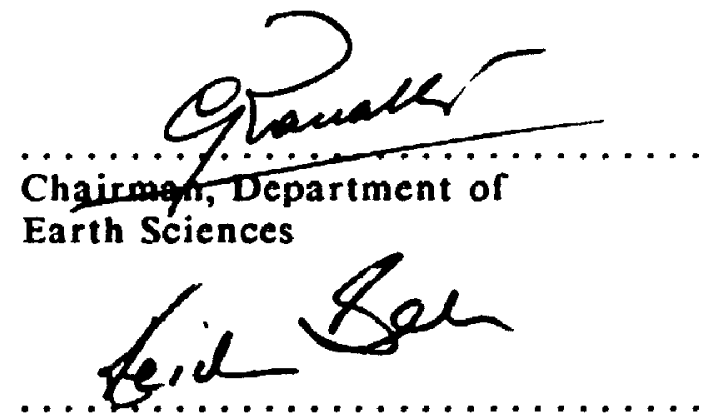

Thesis Supervisor

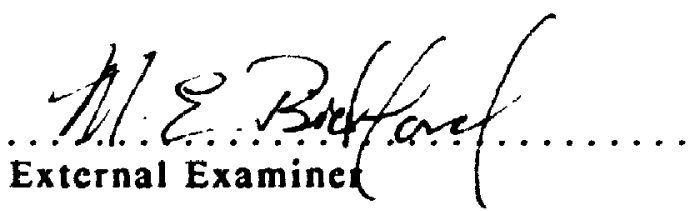




\begin{abstract}
In a transect across the Birbir and Baro domains of western Ethiopia, distinct granitoid suites are recognized on the basis of their field relations, petrology, chemical features and age. The Baro Domain consists of migmatitic, upper amphibolite facies gneisses and meta-leucogranites. The Birbir Domain consists of lower amphibolite facies rocks with abundant intrusive and meta-intrusive rocks of mafic and intermediate composition. A ductile, transcurrent fault system, the Birbir Shear Zone, traverses the Birbir Domain. Kinematic indicators such as disrupted dykes and sills within the shear zone suggest major dextral movement which was succeded by sinistral movement during its final stage. The pre- to syn-kinematic intrusives within the Birbir Domain are metamorphosed and mylonitized to variable degrees. Geochemical and isotopic data from carly plutunic units in the Birbir Domain reflect are-type igneous activity; late- to postkinematic plutons are more alkalic and of intraplate character.

$\mathrm{U}-\mathrm{Pb}$ zircon and $\mathrm{Rb}-\mathrm{Sr}$ whole-rock isochron dates show plutonic activity between 830 and $540 \mathrm{Ma}$. A whole-rock Rb-Sr date of $760 \mathrm{Ma}$ from a pre- to syn-kinematic pluton coincides with the age of low-grade metamorphism of arc-related rocks of the Red Sea Hills of NE Africa and the Jeddah terranc of Arabia. A U-Pb zircon age of $783 \mathrm{Ma}$ was obtained from leucogranite shects of the Baro Domain, considered to be the products of anatexis. A $635 \mathrm{Ma}$ whole-rock, Rb-Sr date is considered to be a time of isotopic equilibration probably associated with major transcurrent movement. A U-Pb lower
\end{abstract}


intercept date of $582 \mathrm{Ma}$ from the Baro leucogranite represents metamorphic overgrowth and coincides with the estimated time of amphibolite facies metamorphism in the Mozambiquian rocks of NW Kenya. Late- to post-kinematic intrusions at 570 and $550 \mathrm{Ma}$ place a minimum age limit on deformation and metamorphism.

The Birbir Domain is a southward extension of the Pan-African crust of NE Africa and Arabia. The Birbir shear zone indicates a tectonically active continental margin along which magmatic arc rocks were accreted. The Baro Domain is interpreted as a reactivated pre- Pan-African continental margin linked to the Mozambique Belt of east Africa. A subduction model, involving closure of an ocean basin, is proposed for the evolution of rocks of the Birbir Domain. In a new synthesis, the Precambrian rocks of Ethiopia are divided into pre- Pan-African and Pan-African assemblages subdivided into nine major lithostructural units. 


\section{Acknowledgements}

I am grateful to my supervisor Dr. Keith Bell for advice, encouragement and patient review of several drafts of this thesis. I also wish to thank him for making available the use of the isotope laboratory and for financial support during the final preparation of the thesis. Dr. John Marshall Mocre. co-ordinator for the Gore-Gambella Geotraverse Project, has been instrumental in all aspects of the project, particularly in reviewing and making helpful suggestions at all stages. This study would not have been possible without his continued support and enthusiasm. I feel deeply indebted to Dr. Randy Parrish of the Geological Survey of Canada who performed the U-Pb zircon analyses and made valuable criticism of the interpretation of the data. I am grateful to Dr. Calvin Pride for his moral support throughout this study. Discussions in and out of the field with Drs. Ralph Kretz, Bill Fyson and Simun Hanmer were especially beneficial.

Laboratory facilities and staff support were provided by Carleton University and the Geological Survey of Canada. I would like to extend my deepest gratitude to all faculty and students of the Ottawa - Carleton Geoscience Centre (OCGC) for their hospitality and partnership during my stay. I would like to sing:= out Charlie Roots, Kian Fadaic, Leo Nadeau, Richard Taylor, Andre Lalonde and Tony Fowler with all of whom I shared îruitful discussions.

Field and logistical support were obtained through Addis Abeba University (AAU) and the Ethiopian Institute of Geological Surveys (EIGS). Dr. Getanch Assefa co-ordinated the Ethiopian working team during the early part of the Project. Mapping was carried out by a large team comprising 
members of AAU, EIGS and OCGC. I would like to thank the entire Geotraverse crew, and most of all Alemu Shiferaw, Amenti Abraham, Begashaw Wolde, Bekele Abcbe, John Morgan, Mengesha Teferra, Mengist Teklay, Pat Allen, Samuel Gichile and Tom Garagan for their enthusiasm and competence during the mapping operation. Some photos were kindly provided by J.M. Moore.

The project was supported by International Development Research Centre, Canada (IDRC) through the Gore - Gambella Geotraverse Project grants to AAU and OCGC. The award to the author of an IDRC graduate fellowship, during a study leave from the Department of Geology of AAU, is gratefully acknowledged.

Last but not least, 1 would like to express my sincere appreciation to my parents and friends who showed their concern all these years. 


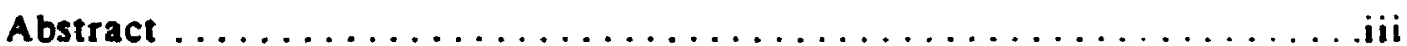

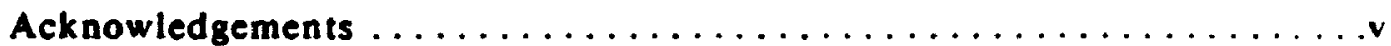

Table of Contents $\ldots \ldots \ldots \ldots \ldots \ldots \ldots \ldots \ldots \ldots \ldots \ldots \ldots \ldots \ldots \ldots$

List of Tables $\ldots \ldots \ldots \ldots \ldots \ldots \ldots \ldots \ldots \ldots \ldots \ldots \ldots \ldots \ldots \ldots \ldots \ldots \ldots$

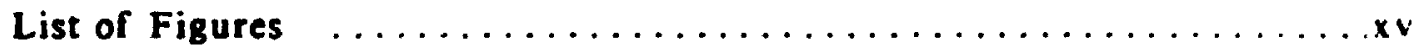

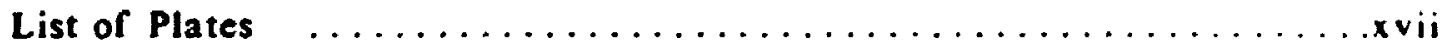

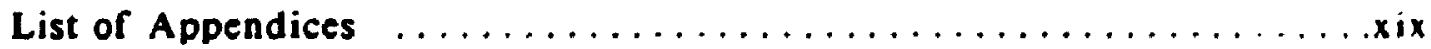

\section{CHAPTER I: INTRODUCTION}

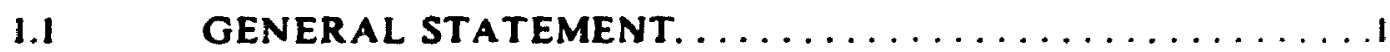

1.2 MOZAMBIQUE BELT AND THE PAN-AFRICAN E.V.EN.T ...4

1.3 STATEMENT OF THE PROBLEM $\ldots \ldots \ldots \ldots \ldots$

1.4 PREVIOUS WORK $\ldots \ldots \ldots \ldots \ldots \ldots \ldots \ldots \ldots \ldots \ldots \ldots \ldots$

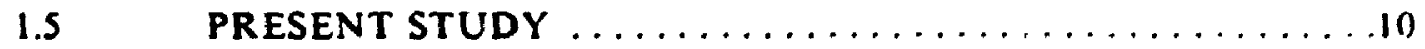

1.6 LOCATION, PHYSIOGRAPHY, ACCESS AND CLIMATE . . . . I

\section{CHAPTER 2: GEOLOGY OF THE GORE - GAMBELLA AREA}

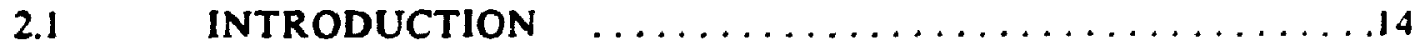

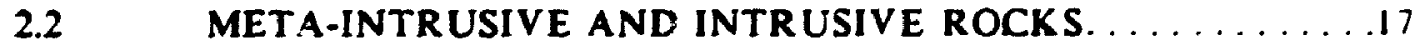

2.2.1 Pre- and/or syn-kinematic plutonic units $\ldots \ldots \ldots \ldots \ldots . \ldots \ldots$

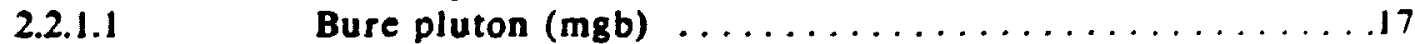

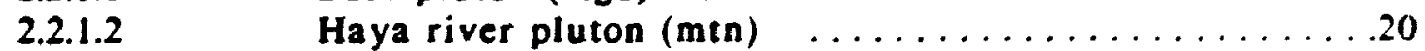

2.2.1.3 Birbir intrusive complex (mqd) $\ldots \ldots \ldots \ldots \ldots \ldots . \ldots \ldots$

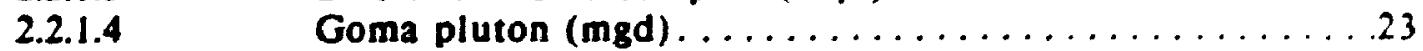

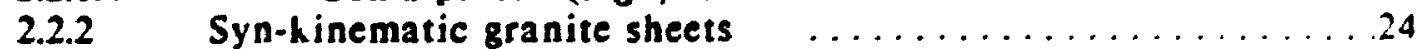

2.2.2.1 Garnet-muscovite granite (mgt) $\ldots \ldots \ldots \ldots \ldots 24$

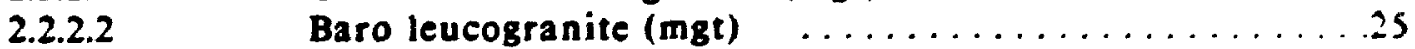




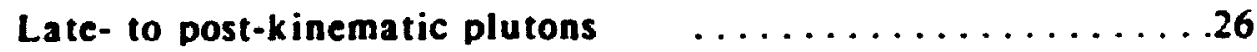

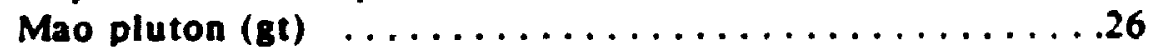

Bonga pluton (gt) $\ldots \ldots \ldots \ldots \ldots \ldots \ldots \ldots \ldots \ldots \ldots \ldots \ldots \ldots .27$

Gabbro, diorite and hornblendite (gb, hbt) $\ldots \ldots .28$

2.3 METAMORPHOSED SEDIMENTARY, VOLCANIC AND

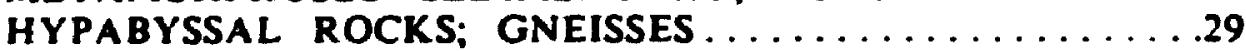

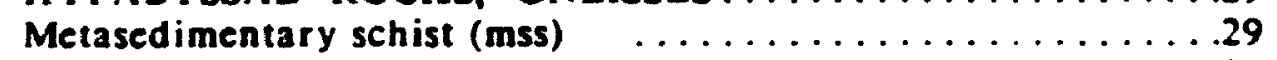

Metavolcanic schist and mylonite (mvs) $\ldots \ldots \ldots \ldots \ldots \ldots$

Garnet-sillimanite gneiss (858), calc-silicate gneiss (csg) and muscovite-bearing gneiss (msg) $\ldots \ldots \ldots 32$ Quartz - muscovite schist and conglomerate (qms) $\quad \ldots \ldots . .32$ Biotite gneiss (big) and hornblende-biotite

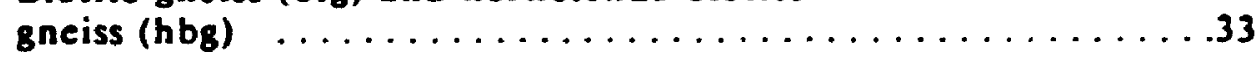

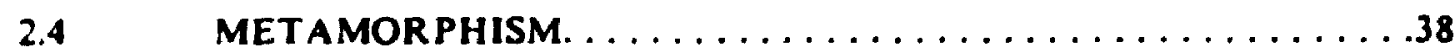

2.4.1 Mineral parageneses and PT conditions $\ldots \ldots \ldots . \ldots 38$

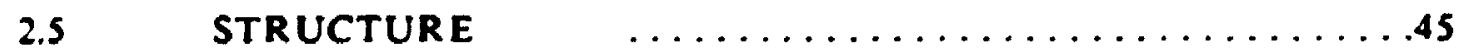

2.5.1 Gneissic terranes $\ldots \ldots \ldots .45$

2.5.2 Birbir Domain $\ldots \ldots \ldots .46$

2.5.3 Birbir Shear Zone $\ldots \ldots \ldots .47$

2.6 DISCUSSION $\ldots \ldots \ldots \ldots .52$

\section{CHAPTER 3: PETROCHEMISTRY}

3.1 GENERAL StATEMENT. $\ldots \ldots \ldots \ldots \ldots \ldots \ldots \ldots$

3.2 GEOLOGICAL SETTING $\ldots \ldots \ldots \ldots \ldots \ldots \ldots \ldots \ldots \ldots \ldots$

3.3 SAMPLING AND ANALYTICAL METHODS. . . . . . 62

3.4 ALTERATION AND METAMORPHISM $\ldots \ldots \ldots \ldots \ldots . \ldots . \ldots$

3.5 GEOCHEMICAL CLASSIFICATION $\ldots \ldots \ldots \ldots \ldots \ldots$

3.6 MAJOR - AND TRACE ELEMENT CHEMISTRY . . . . . . 72

3.6.1 Pre- to syn-kinematic mafic and intermediate intrusive

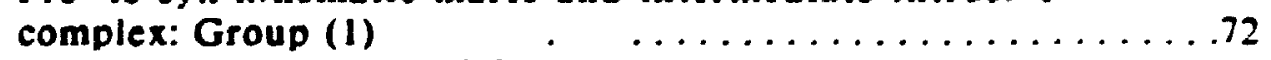

3.6.2 Peraluminous and alkali-feldspar granites: groups

(2) and (3) 
REE DISTRIBUTION $\ldots \ldots \ldots \ldots \ldots \ldots \ldots \ldots \ldots$ ?

3.8 TECTONIC IMPLICATIONS $\ldots \ldots \ldots \ldots \ldots \ldots \ldots \ldots \ldots$

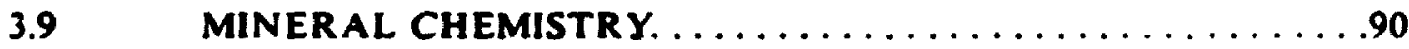

3.9.1 Pressure and temperature of crystallization . $\ldots . .90$

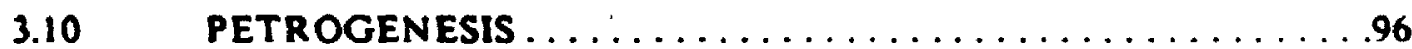

3.10.1 Mafic and intermediate intrusive complexes: Group

3.10.1.1 Quantitative modeling of ma jor and trace

3.10.1.2 Origin of the Birbir Intrusive complex $\ldots \ldots \ldots \ldots .101$

3.10.2 Peraluminous granite suite: Group (2) $\ldots \ldots \ldots \ldots \ldots \ldots 104$

3.10.3 Alkali-feldspar granite suite: Group (3) $\ldots \ldots \ldots \ldots \ldots .105$

CHAPTER A: GEOCHRONOLOGY AND ISOTOPE GEOCHEMISTRY

4.I GENERAL STATEMENT $\quad \ldots \ldots \ldots \ldots \ldots \ldots \ldots \ldots \ldots$

4.2 INTRODUCTION $\quad . \quad \ldots \ldots \ldots \ldots \ldots \ldots \ldots \ldots \ldots \ldots$

4.3 U.Pb ANALYSES OF ZIRCON AND THE CONCORDIA DIAGRAM $\ldots \ldots \ldots \ldots \ldots \ldots \ldots \ldots$

4.3.1 Analytical methods .......................

4.3.2 Pre-and/or syn-kinematic intrusive recks ........116

4.3.3 Syn-kinematic Baro leucogranite ..............116

4.3.4 Late- to post-kinematic plutons $\ldots \ldots \ldots \ldots \ldots \ldots \ldots \ldots$

4.4 Rb-Sr SYSTEMATICS AND THE ISOCHRON DIAGRAM . . . 128

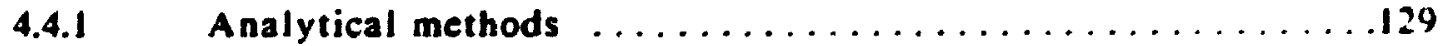

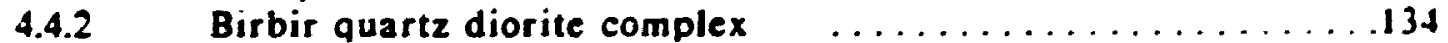

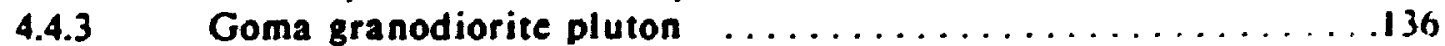

4.4.4 Late- to post-kinematic plutons $\ldots \ldots \ldots \ldots \ldots \ldots \ldots \ldots$

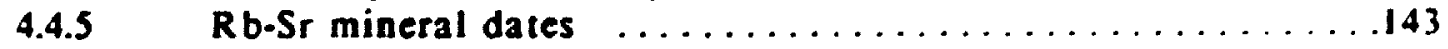

4.4.6 $\mathrm{Rb} \& \mathrm{Sr}$ concentrations and $\mathrm{Sr}$ isotopic compositions $\ldots .43$

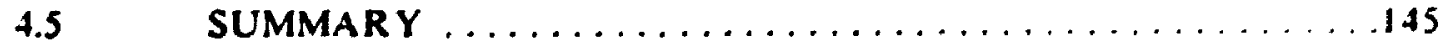




\section{CHAPTER 5: DISCUSSION AND INTERPRETATION}

S.1 GENERAL STATFMENT $\ldots \ldots \ldots \ldots \ldots \ldots \ldots \ldots \ldots \ldots$

5.2 REGIONAL LITHOTECTONIC ASSEMBLAGES $\ldots \ldots \ldots \ldots$

S.2.1 Volcano-sedimentary terranes $\ldots \ldots \ldots \ldots \ldots \ldots \ldots$. $\ldots \ldots$

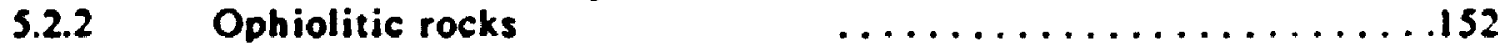

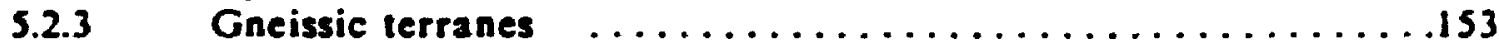

5.3 RELATIONSHIP OF THE BIRBIR DOMAIN TO THE PAN-AFRICAN ARC-TYPE ROCKS $\ldots \ldots \ldots \ldots \ldots \ldots \ldots$

5.4 RELATIONSHIP OF THE BARO AND GEBA DOMAINS TO THE MOZAMBIQUE BELT OF EAST AFRICA $\ldots .156$

5.5 RELATIONSHIP OF THE MOZAMBIQUE BELT ROCKS TO THE PAN-AFRICAN ROCKS IN WESTERN ETHIOPIA

S.6 AGE AND CORRELATION OF PLUTONIC AN!S METAMORPHIC EVENTS ..................159

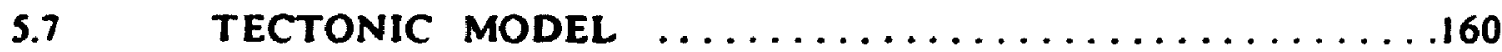

CHAPTER 6: PRECAMBRIAN STRATIGRAPHY AND TECTONICS OF ETHIOPIA

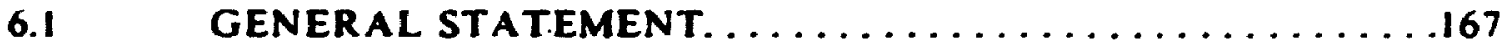

6.2 INTRODUCTION $\ldots \ldots \ldots \ldots \ldots \ldots \ldots \ldots \ldots \ldots \ldots \ldots \ldots$

6.2.1 Lower complex. . . . . . . . . . . . . . . . . . . . 169

6.2.2 Middle complex ..........................170

6.2.3 Upper complex. ..........................170

6.2.4 Other divisions: Omo River Project $\ldots \ldots \ldots \ldots \ldots \ldots \ldots \ldots$

6.3 LITHOSTRUCTURAL UNITS $\ldots \ldots \ldots \ldots \ldots \ldots \ldots \ldots \ldots$

6.3.1 Western gneiss zone (WGZ) $\ldots \ldots \ldots \ldots \ldots \ldots \ldots \ldots \ldots \ldots$

6.3.2 Central gneiss zone (CGZ) $\ldots \ldots \ldots \ldots \ldots \ldots \ldots \ldots \ldots \ldots$

6.3.3 Southern gneiss zone (SGZ) $\ldots \ldots \ldots \ldots \ldots \ldots \ldots \ldots \ldots \ldots$

6.3.4 Yavello paragneiss zone (YPZ) $\ldots \ldots \ldots \ldots \ldots \ldots \ldots \ldots \ldots 17$

6.3.5 Tullu Dimtu ophiolitic rocks $\ldots \ldots \ldots \ldots \ldots \ldots \ldots \ldots$

6.3.6 Birbir magmatic zone (BMZ) . . . . . . . . . . . . . . 179

6.3.7 Northern volcanic-sedimentary terrane (NVST) $\ldots \ldots \ldots \ldots 180$

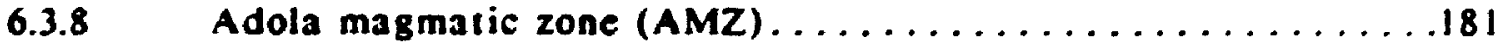



6.4 SUMMARY
6.4 .1
Reactivated pre- Pan-African rocks
6.4 .2
Pan-African rocks
6.5
RELATIONSHIP OF PRE-PAN-AFRIC AN
ROCKS IN WESTERN ETHIOPIA
AND PAN-AFRICAN
..........184

\section{CHAPTER 7: CONCLUSIONS}

7.1

GEOLOGY

186

7.2 GEOCHEMISTRY

7.3 GEOCHRONOLOGY.

7.4 CONCLUDING NOTES

REFERENCES

\section{APPENDICES}

Appendix 1: PETROGRAPHY

Appendix 2: MAJOR- AND TRACE ELEMENT ROCK ANALYSES, ANALYTICAL PROCEDURE AND ACCURACY . . .216

Table A2.2: Accuracy determined for XRF analyses .217

Table A2.2: Whole-rock chemical data and CIPW norms .219

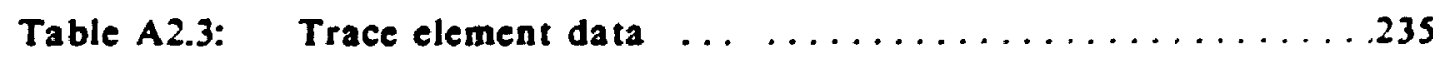

Appendix 3: MICROPROBE MINERAL ANALYSES..........236

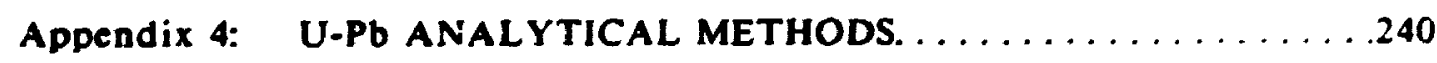


Appendix 5: Rb-Sr ANALYTICAL METHODS

A5.1: DISSOLUTION AND PREPARATION OF WHOLE-ROCK POWDERS FOR Rb-Sr STUDIES ..............244

A5.2: CALIBRATION FOR SEPARATING Rb AND Sr FROM WHOLE-ROCK POWDERS FOR MASS SPECTROMETRY

A5.3: MASS SPECTROMETR: 


\section{LIST OF TABLES}

2.! Typical modes of representative samples of meta-intrusive

Page and intrusive rocks

2.2 Typical mineral assemblages of the metasedimentary and volcanic rocks and gneisses $\ldots \ldots . . .30$

3.I Average and range of chemical composition and CIPW norms of gabbro-tonalite association of Group (1) plutons

3.2 Average and range of chemical composition and CIPW norms of quartz diorite association of Group (1) plutons $\ldots \ldots .57$

3.3 Average and range of chemical composition and CIPW norms

3.4 Average and range of chemical composition and CIPW norms of Group (3) plutons

3.5 Trace element contents and ratios in plutonic rocks $.60-61$

3.6 Summary of the petrologic and chemical characteristics of the plutonic units in the Birbir Domain

3.7 Summary of absolute REE abundance, LREE/HREE and Eu anomalies in all plutonic units

3.10 Average microprobe analyses of epidote from Birbir quartz diorite compared to analyses of magmatic epidote

3.8 Hypothetical liquid compositions for testing the feasibility of fractional crystallization in the calc-alkaline suite of Group (1) plutons

3.9 Least squares mass-balance calculations and results for major element fractionation

4.1 List of isotopic age determinations from Precambrian rocks of Ethiopia .......................... 108

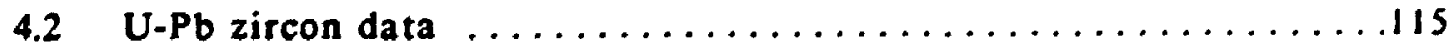

4.3 Rb-Sr data of whole rocks and biotite $.131-132$

4.4 Results of various regression values for whole-rock $\mathrm{R} \mathrm{b}-\mathrm{Sr}$ data 
5.1 Summary of age and correlation with Pan-African events in the region

6.1 Idealized lithostratigraphy of western Ethiopia.. 


\section{LIST OF FIGURES}

1.1 Sketch map showing geographical relationships between the western Ethiopia, NE African and Arabian shields $\ldots \ldots \ldots .2$

1.2 Palinspastic sketch map of tectonic terranes in the Afro-Arabian region

1.3 Sketch map of the northern part of the Mozambique Belt and Pan-African rocks of Ethiopia, NE Africa and Arabia, showing main structural trends .5

1.4 Location map of the Gore - Gambella Geotraverse area ......12

2.1 Geological map of the Gore-Gambella Geotraverse showing Baro, Birbir and Geba domains

2.2 Geological map of the Gore-Gambella Geotraverse showing main structural trend lines and sample locations for the plutonic units $\ldots \ldots \ldots \ldots$ in pocket

2.3 Sketch map of the intrusive units studied showing sample localities $\quad \ldots \ldots \ldots \ldots \ldots \ldots \ldots \ldots \ldots$ in pocket

2.4 Petrogenetic grid (after Carmichael, 1985) showing reactions that involve biotite, plagioclase and quartz

(a) for metasedimentary schists and gneiss unit (gsg) of the Baro Domain, (b) in metapelite unit (mss) of the Birbir Domain.

3.1 Classification of the plutonic units in terms of

(a) typical modes of quartz, plagioclase and alkali-feldspar af ter the IUGS system (Streckisen, 1976). (b) Normative classification after Hietanen (1963)

3.2 Normative proportions of $A b, A n$ and Or with classification boundaries of O'Connor (1965)

3.3 AFM (A: $\mathrm{Na}_{2} \mathrm{O}+\mathrm{K}_{2} \mathrm{O} ; \mathrm{F}: \mathrm{FeO}_{(\text {total) }} \mathrm{M}: \mathrm{MgO}$ ) diagram of the meta-intrusive rocks of the Birbir Domain

3.4 (a) Ternary plot of normative $Q, A b$, and Or;

(b) weight proportions of $\mathrm{CaO}: \mathrm{Na}_{2} \mathrm{O}: \mathrm{K}_{2} \mathrm{O}$ 
3.5 Plot of $\mathrm{Na}_{2} \mathrm{O}$ versus $\mathrm{K}_{2} \mathrm{O}$ showing fields for I-, $\mathrm{S}$ - and A-type granites of White and Chappell (1983)

3.6 Variation diagrams for the calc-alkaline suite of Group (1)

plutons ..............................74-75

3.7 Chondrite-normalized REE abundance patterns of representative samples from groups 1,2 and 3

3.8 Trace element tectonic setting discrimination boundaries in terms of a) $Y-N b, b) R b-(Y+N b)$, c) $R b-(Y b+T a)$ and d) $\mathbf{Y b}-\mathbf{T a}$

$3.9 \mathrm{~K}_{2} \mathrm{O}-\mathrm{SiO}_{2}$ variation diagram showıng ficlds for plutonic rocks from various destructive plate settings

3.10 Rb and $\mathrm{Sr}$ co-variation diagram

3.11 Normative quartz, albite and orthoclase of Mao and Bonga plutons compared with minimum melt experimental grid

3.12 a) Feldspar solvi in relation to plagioclase composition

b) $\mathrm{F}$ - OH partitioning in coexisting biotite and apatite

4.1 Concordia diagram for the Birbir pluton

4.2 Concordia diagram for the Goma pluton .118

4.3 Concordia diagram for the Baro pluton .120

4.4 Concordia diagram for the Bonga pluton .124

4.5 Concordia diagram for the Mao pluton .126

4.6 Isochron plot for the Birbir quartz diorite .135

4.7 Two re-set isochrons from the Goma pluton .137

4.8 Isochron plot for the Bonga pluton

4.9 Isochron plot for the Mao pluton

4.10 Rb-Sr whole-rock data showing various regressed values .142 
5.1 Palinspastic sketch map of the NE African (Nubian) and Arabian Shield showing its spatial relationship with the western Ethiopian Shicld and the northern part of the Mozambique Belt.

5.2 Cartoon showing a tectonic model for the late Proterozoic rocks of western Ethiopia

6.1 Sketch map of the Precambrian rocks of Ethiopia showing the distribution of the proposed lithotectonic units 


\section{LIST OF PLATES}

\subsection{Field aspects of some map-units from the Birbir and} Baro domains
A) Mafic xenoliths in (mqd)
B) Rapakivi texture in quartz monzonite of Bonga pluton (gt)
C) Cyclic layering of pelite and wacke (mss)
D) Andesitic flows (mvs)
E) Coarse volcaniclastic rock (mss)
F) Sillimanite-quartz knots (gsg)

\subsection{Metamorphic mineral assemblages; Primary and} tectonic structures in Birbir plutonic units.
A) Assemblage garnet-cordierite-gedrite-sillimanite (gsg)
B) Staurolite porphyroblasts in fine-grained matrix
C) Mafic xenolith truncated by shear zone associated with sinistral shear in (mqd)
D) Extension lineation in (mqd)
E) Shear foliation in (mqd)
F) Folded mylonitic foliation in (mqd)

\subsection{Stages of mylonitization in Birbir quartz diorite (mgd); plutonic textures}
A) Subhedral-granular texture in protomylonite (mqd)
B) Bending and kinking of plagioclase twin lamellae
C) Plagioclase phenoclasts showing deformation twins 
D) Recrystallization and granoblastic texture

E) Biotite, hornblende, euhedral epidote and titanite

F) Polygonized quartz ribbons around $\mathrm{K}$-feldspar porphyroclasts

G) C-S fabric in mylonite (mad)

H) Garnet - muscovite granite (mgr)

1) Biotite enclosing euhedral zircons in Bong granite (gt).

4.1: Scanning electron microscope images of HF etched zircon grain mounts from the Bare and Mao plutons

$\ldots 120$

xix 


\section{LIST OF APPENDICES}

Appendix I Petrography

Appendix 2 Major and trace element rock analyses, analytical procedurcs and accuracy

Appendix 3 Microprobe mineral analyses

Appendix $4 \quad \mathrm{U}-\mathrm{Pb}$ analytical methods .242

Appendix $5 \mathrm{Rb}-\mathrm{Sr}$ analytical methods .245 


\section{CHAPTER 1}

\section{INTRODUCTION}

\subsection{GENERAL STATEMENT}

The Precambrian Shield of western Ethiopia occupies a position of particular interest, lying at the interface between the predominantly gneissic terrane of the Mozambique orogenic belt to the south in East Africa and the volcanic-sedimentary-plutonic rocks of the north-cast African Shicld (Figs. 1.1 and 1.2). The north-east African Shield extends from eastern Egypt southward through eastern Sudan and Ethiopia and westward through Libya. The counterparts of the north-east African Shield found in the Arabian peninsula, Saudi Arabia and eastern Oman were once a segment of a formerly continuous orogenic belt, now separated by the Red Sea and the Gulf of Aden.

In western Ethiopia, the shield is made up of a mosaic of high-grade gneisses separated by lower-grade rocks. The contact and age relationships between adjacent rocks of contrasting metamorphic grade have been a source of controversy, and nowhere has the relationship between the two groups of rocks been conclusively resolved. This problem was first addressed by Shackleton (1967) who correlated lower-grade rocks from southern Ethiopia with similar rocks in Kenya. He considered these low-grade sequences to be younger, supracrustal rocks underlain by older metamorphosed and deformed basement. Mohr (1962), Kazmin (1971, 1972b) and Merla et al.(1973, 1979). amongst others, also proposed a basement - cover relationship. However, neither the physical relationships nor the geochronological work undertaken to date support this hypothesis. 


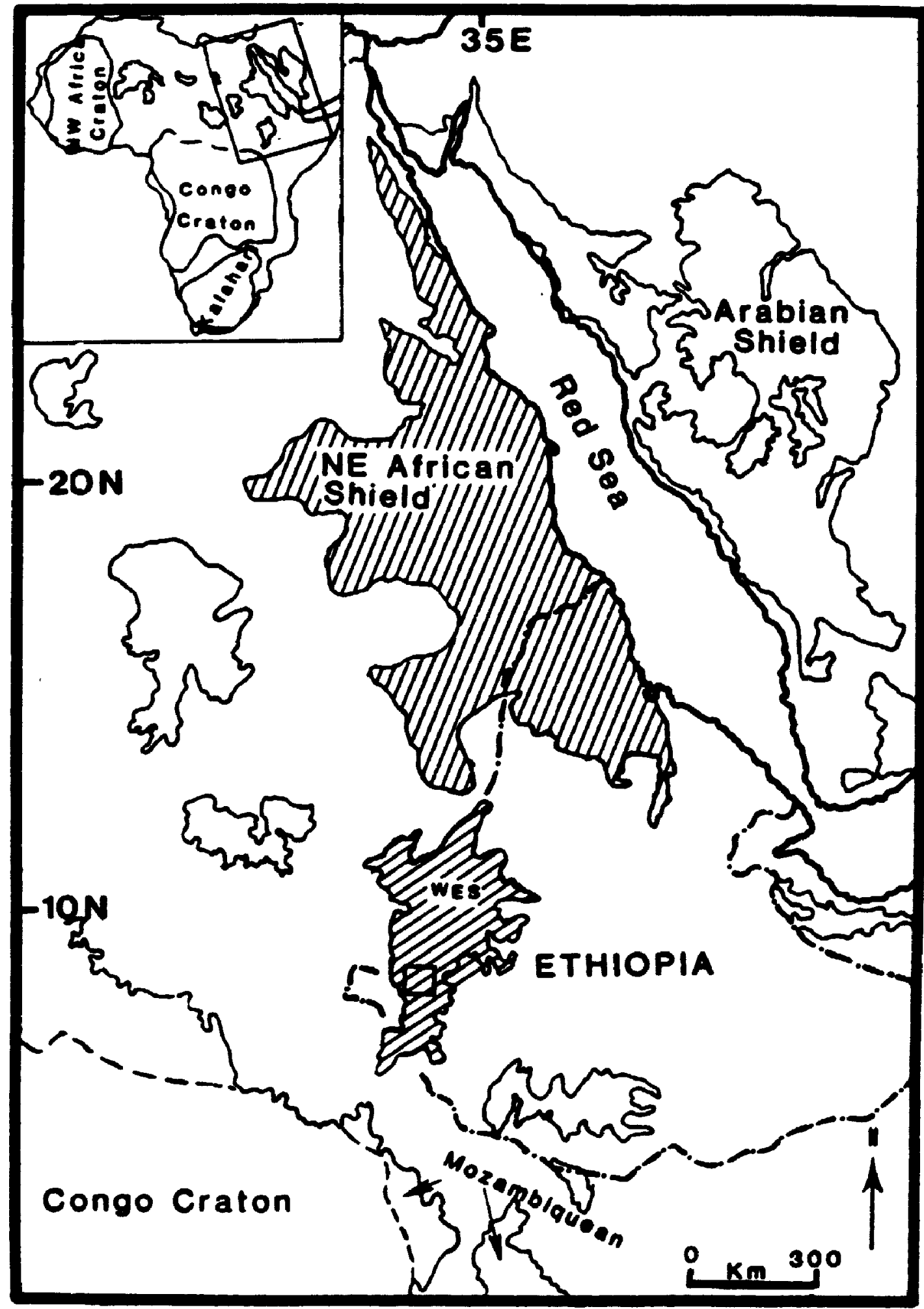

Figure 1.1: Skesch map of the Precambrian rocks of the region showing geographical relationships between the western Ethiopian. NE Afriean Shiclds (patterned). and rocks of the Mozambique Bctt.

WES: Hestern Ethiopian Shicld. Small square in WES denotes study area. 


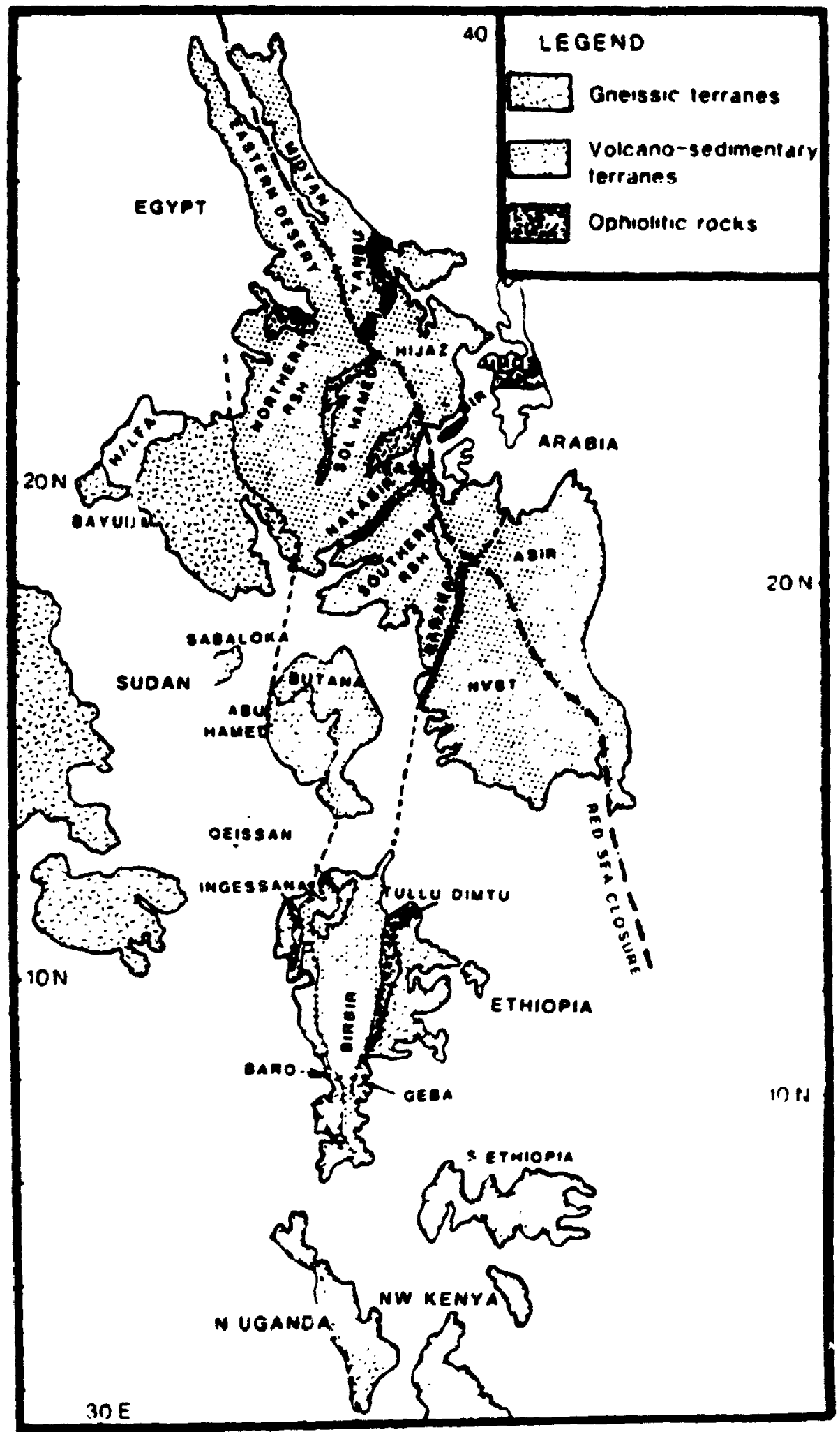

Figure 1.2: Palinspastic sketch map of NE African, Arabian and western Ethiopian Shields showing the major tectonic terranes. Note the relationship between the Baro. Birbir and Geba domains of the study area and the distribution of the high-grade gneissic terranes and the lower-grade volcano-sedimentary terranes and ophiolitic rocks in the region. Notc also the shift in seographic coordinates east and west of the Red Sea closure line. RSH. Red Sea Hills. Modified after Vail (1985). 
In the Gore - Gambella area of western Ethiopia rocks belonging to both high-and low-grade assemblages are well-exposed and in mutual contact. An Ethiopian - Canadian Cooperative Geotraverse, carried out from 1984 to 1986. allowed systematic mapping of the area. This thesis was part of the supporting laboratory studies of the Geotraverse.

\subsection{MOZAMBIQUE BELT AND THE PAN-AFRICAN EVENT}

The Precambrian rocks of Ethiopia were originally regarded as the north ward continuation of the Mozambique Belt (Fig. 1.3; Rogers et al., 1965: Cahen and Snelling. 1966; Cahen et al., 1984). The term "Mozambique Belt" was originally introduced by Holmes (1951), and subsequently redefined by many authors, to describe a north-south trending complex. stretching sub-parallel to the present African east coast, superimposed on more ancient east-west structures. Cahen (1961), among others, described the Mozambique Belt as polycyclic, containing a number of stratigraphic units and exhibiting several periods of deformation. The Mozambique Belt contains early Proterozoic, and possibly Archean units, although most isotopic dates indicate late Proterozoic activity (Wendt et al., 1972; Martin and Porada, 1977; Black, 1984; Almond, 1984; Gabert, 1984).

Hepworth (1979) described the Mozambique Belt in Mozambique, Malawi, Tanzania, Kenya, Uganda and Ethiopia as containing numerous locally-named, lithostratigraphic groups which vary in lithology and metamorphic grade, from granulite and amphibolite facies gneisses and schists to low grade psammites and pelites. He restricted the use of the term "Mozambique Belt" to eastern Africa. with its possible extensions to the west and south: the Zambezi belt and the Damaran-Katangan. Clifford (1970, p. 13) suggested the 


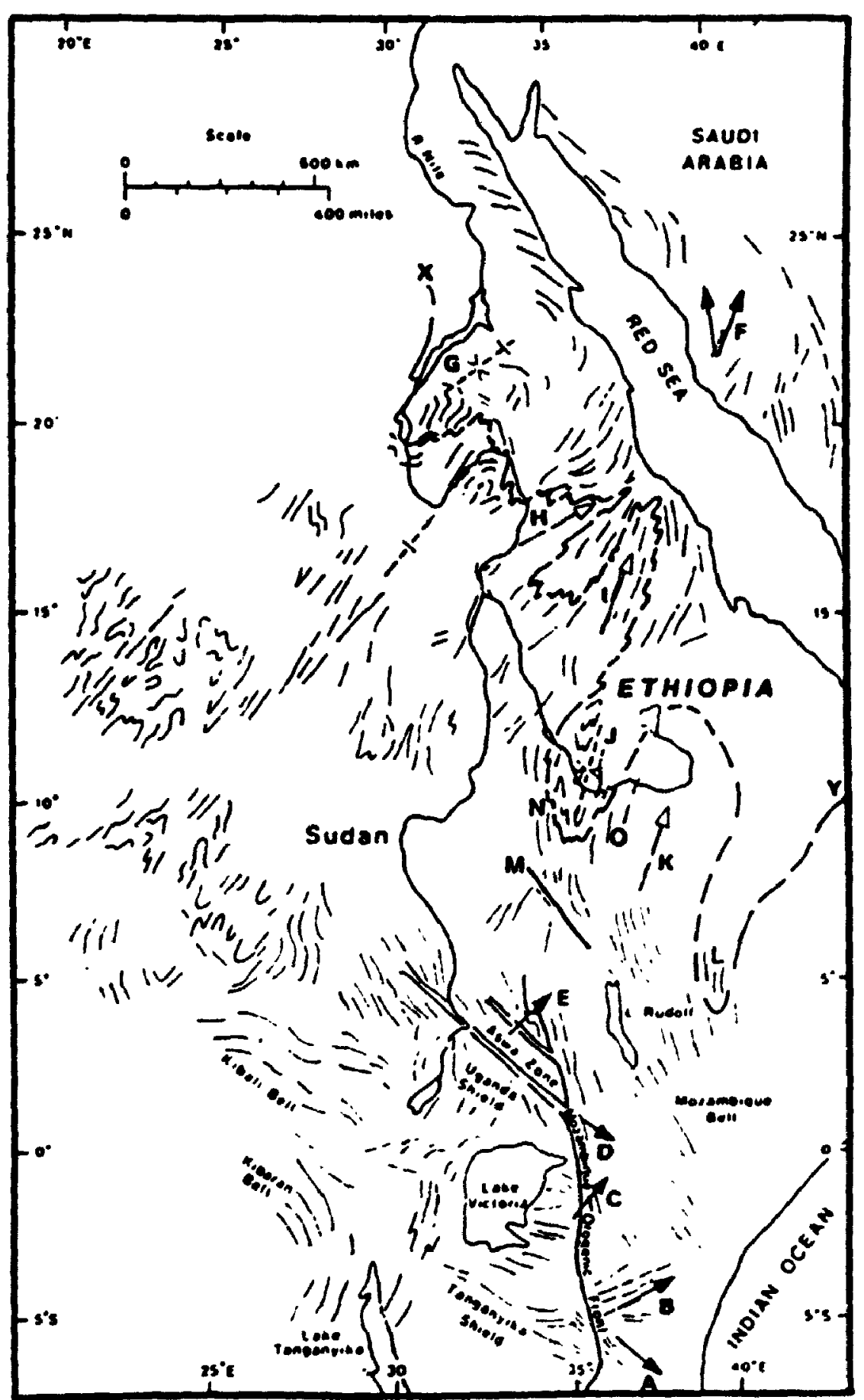

Figure 1.3: Sketch map of the northern part of the Mozambique Palt and rocks affected by the Pan-African cvent in NE Africa and Arabia, showing main structural trends. Solid arrows ABCDE represcnt known Mozambique Belt trends, and open arrows and dashed lines at Gillisk ars inferred fold axis and axial surface trends. $J$ is the Birbir Domain. $V$ and $O$ are the Baro and Geba gncisses of western Ethiopia respectivel; $L$ is the Adola zonc in southern Ethiopia. $M$ is the Surma myloniti zone. $X Y$ is the boundary between Pan-African rocks and pre- lan. African crust (basement?). Modificd after Hepworth 11979). 
presence of "two types of zone within the Mozambique Belt, one "geosynclinal" and the other "vestigial" (rejuvenated basement). The NE African volcanic - sedimentary greenschist belts are considered examples of the geosynclinal type and the relatively high-grade gneissic terranes vestigial. Clifford's classification implies that the gneissic terranes are older than the lower-grade metamorphic rocks.

Rocks of the Mozambique Belt are supposedly affected by the "PanAfrican" event (Kennedy, 1964) that involved the structural differentiation of Africa into cratons and mobile belts during the late Proterozoic and carly Paleozoic (550+/-100 Ma). Burke and Dewey (1973) proposed that the belt is the root of a Himalayan-type continental collision zone of ti:e late Proterozoic age. Kroner (1977) pointed the transitional nature of the western margin and the continuity of lithology from the foreland into mobile belt.

Several discussions of the term "Pan-African", as related to the Precambrian shield of NE Africa and Arabia, have appeared in recent years but no consensus has yet been reached regarding its significance and its age. In contrast to the views held by Kennedy and others concerning the PanAfrican event, the IGCP Project 164 (Al Shanti, 1979) used the term to define various cycles of magmatism, sedimentation and tectonism during the time span 1100-450 Ma. Jackson and Ramsay (1980) recommended the use of "Pan-African" as a general designation for a $550+/-100 \mathrm{Ma}$ old "late Proterozoic pervasive crustal heating event" and suggested that local names be given to the various magmatic and metamorphic events or orogenic eycles. Gabert (1984) considered the Pan-African event of the Mozambique Belt as representing an aborted Hercyno-type orogeny, during which geothermal 
gradients were raised over a large part of the Pangacic supercontinent. resetting many isotopic systems. Dissenting views shared by Hepworth (1979) and Almond (1984) favour the use of the term Pan-African to define an age province or thermal event, without tectonic connotations.

Within recent years there has been considerable success in applying plate tectonic models to those areas affected by the Pan-African event. Numerous tectonic models have been proposed, most involving Wilson Cycles. Typical collision signatures such as sutures and ophiolites have been documented. Implicit in these models is a complex history of island arc formation and ocean closure that involved some combination of arc-arc, arccontinent and/or continent-continent collision. These models are supported by the thick calc-alkaline successions, and isotopic signatures that favour an ensimatic origin (Fleck et al., 1980) as weil as the presence of ophiolitic rocks (Shackleton, 1977; Hussein et al., 1982).

These magmatic arc and ophiolitic assemblages constituted new additions to the continental crust and are considered to de of Pan-African age (Gass. 1981). Although individual models differ in detail, most investigators attribute cratonization of the Pan-African rocks to arc accretion (e.g. Shackleton et al. 1980; Gass, 1977, 1981; Vail, 1983, 1985). However, many workers are still skeptical about such broad generalizations. The absence of blue-schist assemblages, the longevity and episodic character of magmatic activity and lack of paleomagnetic data fail to add support to such a model.

It is also apparent that Pan-African mobilization has affected areas extending several hundred kilometres west of the margins of the known PanAfrican rocks. Older rocks, unaffected by the Pan-African event, are recognized in the Central African Republic (the Congo craton); the western 
limit of the late Proterozoic structures appears to extend through Sudan, west of longitude $34^{\circ} \mathrm{E}$ in a roughly N-S direction (Vail, 1985; Shackleton, 1986).

\subsection{STATEMENT OF THE PROBLEM}

There are still very many questions concerning the evolution of the western Ethiopian Shield, and its relationship to the NE African Shield. Included among these are:

I do the gneissic terranes in western Ethiopia represent an extension of the Mozambique Belt of East Africa?

2 do the small blocks of gneissic rocks represent fragments of pre- Pan-African continental crust?

3 do the ultramafic bodies represent remnants of ophiolite complexes? If so, do the sutures mark fossil subduction zones?

4 are the lower-grade, volcanic-plutonic-sedimentary rocks parts of magmatic ares, and if so are the ares continental or oceanic?

5 what was the time at which new crust was generated during the Pan-African event?

\subsection{PREVIOUS WORK}

Geological mapping of the Precambrian rocks of Ethiopia is fairly localized and consists mainly of either reconnaissance traverses or detailed surveys commonly associated with mineral prospecting sites, e.g. Libling and Nowack (1939), Dainelli (1943), Gherardi (1951), Usoni (1952), Molly (1960), Augustithis (1965), Jelenc (1966), Baines and Duesing (1966), Levitte and Kent (1968), Ball (1971), UNDP (1972), Nippon Mining Company (1974), and 
Ciarke (1978).

Mohr (1962) summarized the results of early reconnaissance geologic mapping of the Precambrian rocks of Ethiopia, and Rogers et al. (1965) undertook the first K-Ar dating programme of Precambrian rocks of the region. Gilboy (1970) and Chater (1971) gave detailed accounts of the petrology, metamorphism, structure and gecchronology of the Precambrian of the Gariboro and Megado region in southern Ethiopia. Both concluded that Precambrian rocks within southern Ethiopia at: similar to those that crop out elsewhere within the northern portion of the Mozambique Belt and proposed a regional correlation between the two. Beyth (1971) and Morton (1975) also published detailed field relations of various parts of the Precambrian rocks of Ethiopia. Kazmin (1971, 1972b, 1975a and b) proposed stratigraphic subdivisions and, for the first time, attempted a tectonic synthesis of the Precambrian in Ethiopia. In 1973, the Geological Survey of Ethiopia published the first geological map of Ethiopia, at a scale of 1:2,000,000. The National Research Council of Italy also published a geological map of Ethiopia and Somalia (Merla et al., 1973, 1979). A reconnaissance geological and geochemical survey of southwestern Ethiopia was supported by CIDA (Canadian International Development Agency; Omo River Project Team, 1973, 1976; Davidson, 1983).

The relatively high-grade metamorphic rocks of western Ethiopia werc considered by most as basement, equivalent to the Mozambique Belt rocks. reworked during the Pan-African event. Arguments were based mainly on ficld relationships, such as different styles of deformation, metamorphic changes and truncation of major rock units. In recent years, however, such vicws have been critically evaluated in terms of Precambrian plate tectonics. New 
concepts of regional tectonics and the significance of ophiolite occurrences have been discussed by Kazmin (1976, 1978a and b), de Wit (1977), de Wit and Berg (1977), Kazmin et al. (1978, 1979), and de Wit and Chewaka (1981).

Interest in the Precambrian rocks of the Gore - Gambella area was stimulated by regional geological mapping of the study area by Teferra and Berhe (unpublished manuscript) of the Ethiopian Institute of Geological Surveys. An important account of the geology of the study area was also given by de Wit (1977).

\subsection{PRESENT STUDY}

The present study is part of a co-operative research project, the GoreGambella Geotraverse, undertaken by the the Department of Geology, Addis Abeba Iniversity and the Ethiopian Institute of Geological Surveys in collaboration with the faculty and staff of the Ottawa - Carleton Geoscience Centre. The geotraverse was financed by the International Development Research Centre of Canada.

Field operations began in February, 1984. They extended over two four month field seasons in 1984 and 1985, and 6 weeks in 1986. This thesis is based on work carried out during the traverse and deals mainly with the intrusive and meta-intrusive rocks in the area. Mapping was conducted using 1:50,000 aerial photographs, and strike-normal traverses were made at intervals of approximately 2 to $4 \mathrm{~km}$. The author was involved in mapping during the entire first field season and part of the second field season. Most of the author's second field season involved detailed mapping of several plutonic units and sampling for geochronological and chemical studies. Laboratory work was undertaken at Ottawa - Carleton Geoscience 
Centre and the Geological Survey of Canada.

Laboratory studies included:

1. Petrographic study of over 200 samples from all rock types of the study area.

2. Major and some trace element analysis of whole-rock samples using X-ray fluorescence.

3. Determination of trace elements, including rare earth elements (REE), by instrumental neutron activation analysis (INAA).

4. Electron microprobe analysis of some minerals from the intrusive and meta-intrusive rocks.

5. Rb-Sr and U-Pb geochronology.

\subsection{LOCATION, PHYSIOGRAPHY, ACCESS AND CLIMATE}

The Gore - Gambella Geotraverse area is situated between $34^{\circ} 45^{\prime}-35^{\circ} 15^{\prime} \mathrm{E}$ and $8^{\circ} 00^{\circ}-8^{\circ} 30^{\prime} \mathrm{N}$, in the western Ethiopian Shicld. It lies in the central part of Illubabor adminstrative region, and covers an area of 2850 square kilometres (Fig. 1.4).

The area lies in the western fringes of the Ethiopian Highlands, which rise to altitudes greater than 2000 metres and form an extensive plateau massif, bisected by the main Ethiopian and Afar rift systems. The highlands generally slope to the west along the major course of the Baro river, that flows through the centre of the mar area. The eastern limit of the area is an elevated, sub-mature plain, incised by streams draining to the Baro and Birbir rivers. Thin erosional remnants of Tertiary basalts are underlain by Precambrian rocks. The incised terrain merges westward into the Gambella 


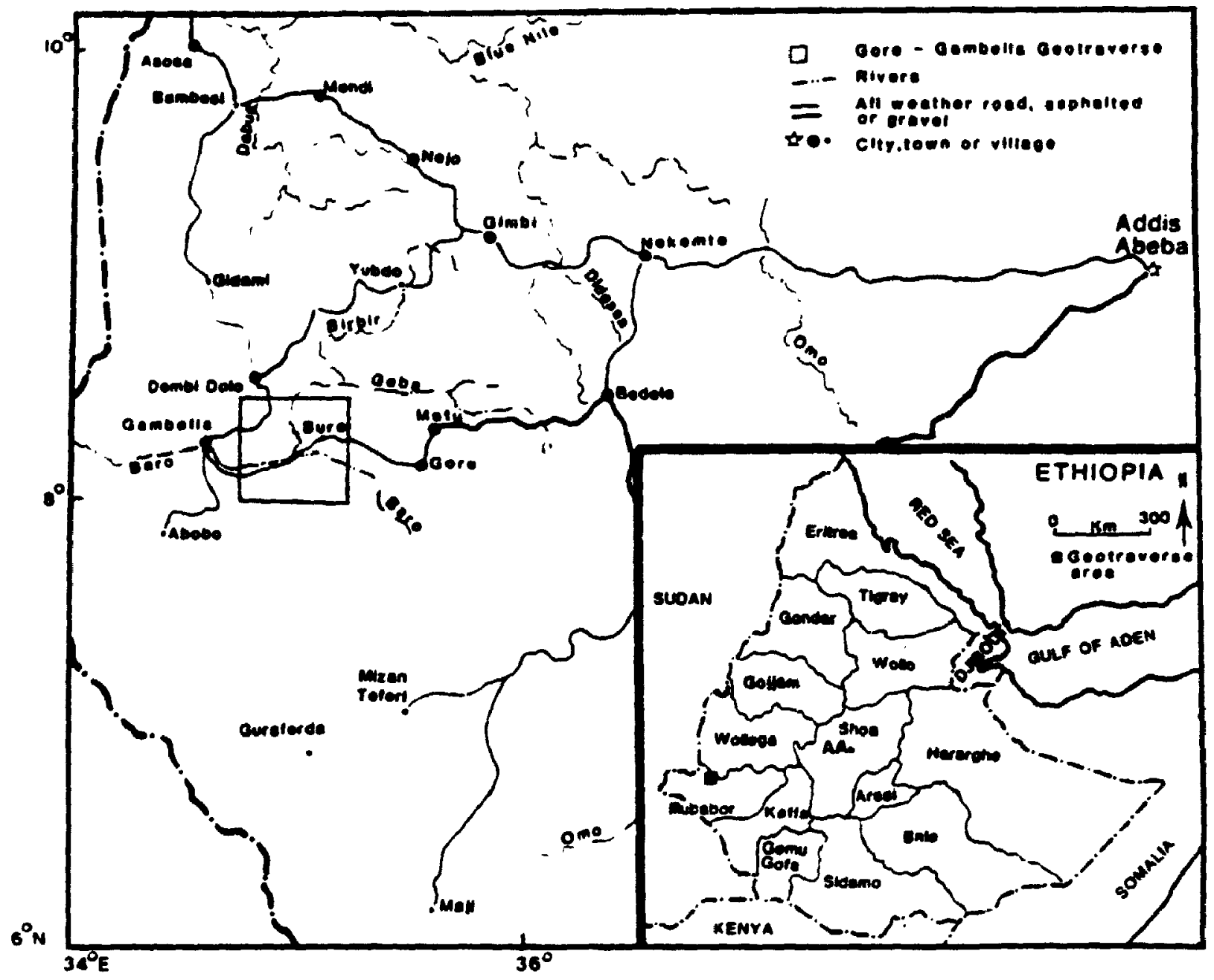

Figure 1.4: Location map of the Gore - Gambella Geotraverse area. 
mature lowland plain, which is also underlain by Precambrian rocks and scattered Tertiary volcanic outliers, with an extensive cover of Quaternary alluvium.

An asphalt road from Addis Abeba to Metu, and an all-weather gravel road from Gore to Gambella run through the area (Fig. 1.4). The northwestern limits of the area are reached via Dembi Dollo by four- wheel drive vehicles. The remaining areas are virtually inaccessible apart from travel by foot. Most traverses were conducted on foot with the help of local labour. The highlands are inhabited by the Oromo people, who subsist on agriculture, and the lowlands by the Mesengo, a semi-nomadis people and the Anuwak, who farm along the river courses.

Insufficient data limit the precise determination of the volume and intensity of rainfall and the variations in temperature in the study area. The eastern and northeastern part of the area have seven rainy months from April to October, with a mean annual rainfall of $1400-1800 \mathrm{~mm}$. Dail; maximum and minimum temperatures range from 12 to $25^{\circ} \mathrm{C}$, and a humid moisture level is reported (Gamechu, 1977). In contrast, the western lowland is dry and seasonally very hot. During the field work, between February and May, daytime shade temperatures in excess of $40^{\circ} \mathrm{C}$ were recorded, and rainfall has been estimated at $600 \mathrm{~mm}$ annually, falling mainly between May and September. 


\section{CHAPTER 2}

\section{GEOLOGY OF THE GORE - GAMBELLA AREA}

\subsection{INTRODUCTION}

The area mapped during the Gore - Gambella Geotraverse consists of a 55 $\mathrm{km}$ section across strike that straddles the boundary between three lithostructural domains, identified on the basis of previous mapping (Teferra and Berhe, unpublished). The domains are, from west to east: 1) the Baro Domain, 2) the Birbir Domain and (3) the Geba Domain (Fig 2.1).

Lithologic assemblages in the Birbir Domain include metamorphosed pelite, wacke, volcaniclastic debris flow deposits, volcanic rocks, mylonite and voluminous plutonic rocks. The Baro and Geba domains consist of heterogeneous ortho- and paragneisses and migmatites. Along the eastern edge of the Baro Domain metasedimentary schists and gneisses occur that include pelites, calc-silicate rocks and amphibolites.

Field relationships and lithological descriptions of the map units are provided in this chapter. The map units are mainly composite, and names assigned to them are based on lithology. The order of many of these units in the legend is arbitrary, as their age relationships are unknown. The intrusive rocks, however, can be grouped according to degree of deformation and contact relations into pre- to synkinematic, and late- to post-kinematic plutons. The mapping units are divided into two broad groups of (1) intrusive and meta-intrusive rocks and (2) metamorphosed volcanic, sedimentary and hypabyssal rocks, and gneisses.

Intrusive and meta-intrusive unit names are given on Figure $2.2^{*}$. Modal mincralogy of selected samples from the intrusive and meta-intrusive rocks 
Figure 2.1: Geological map of subshcets O. P. U. V. Shect NC36-16. Heavy ornamented lines: domain boundaries. Order in iegend of some mapping units is arbitrary (after Moore ct al., 1987)

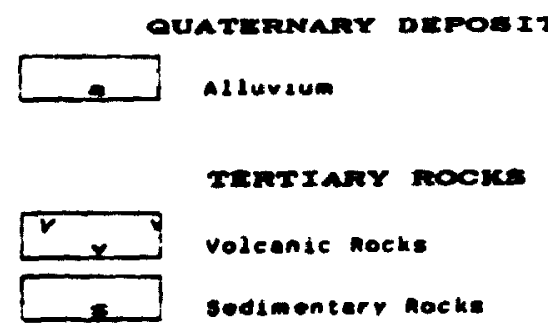

precame tan hocks

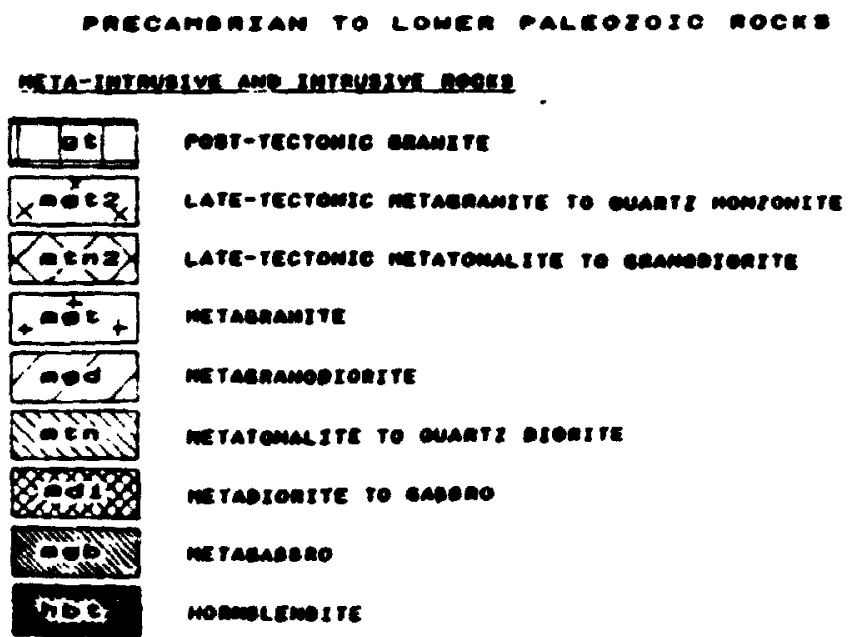

\section{trantzetre necre}

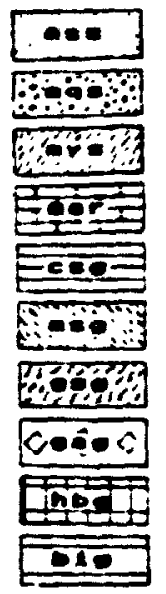

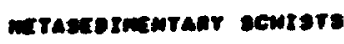

nicackous cuatz sensers

nveonstic schists

mante

CALG-sILICATE entisa

mecovt TE-UEAntm aniss, semist

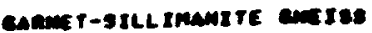

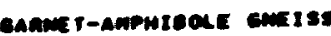

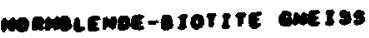

erotste crise 
Bis:
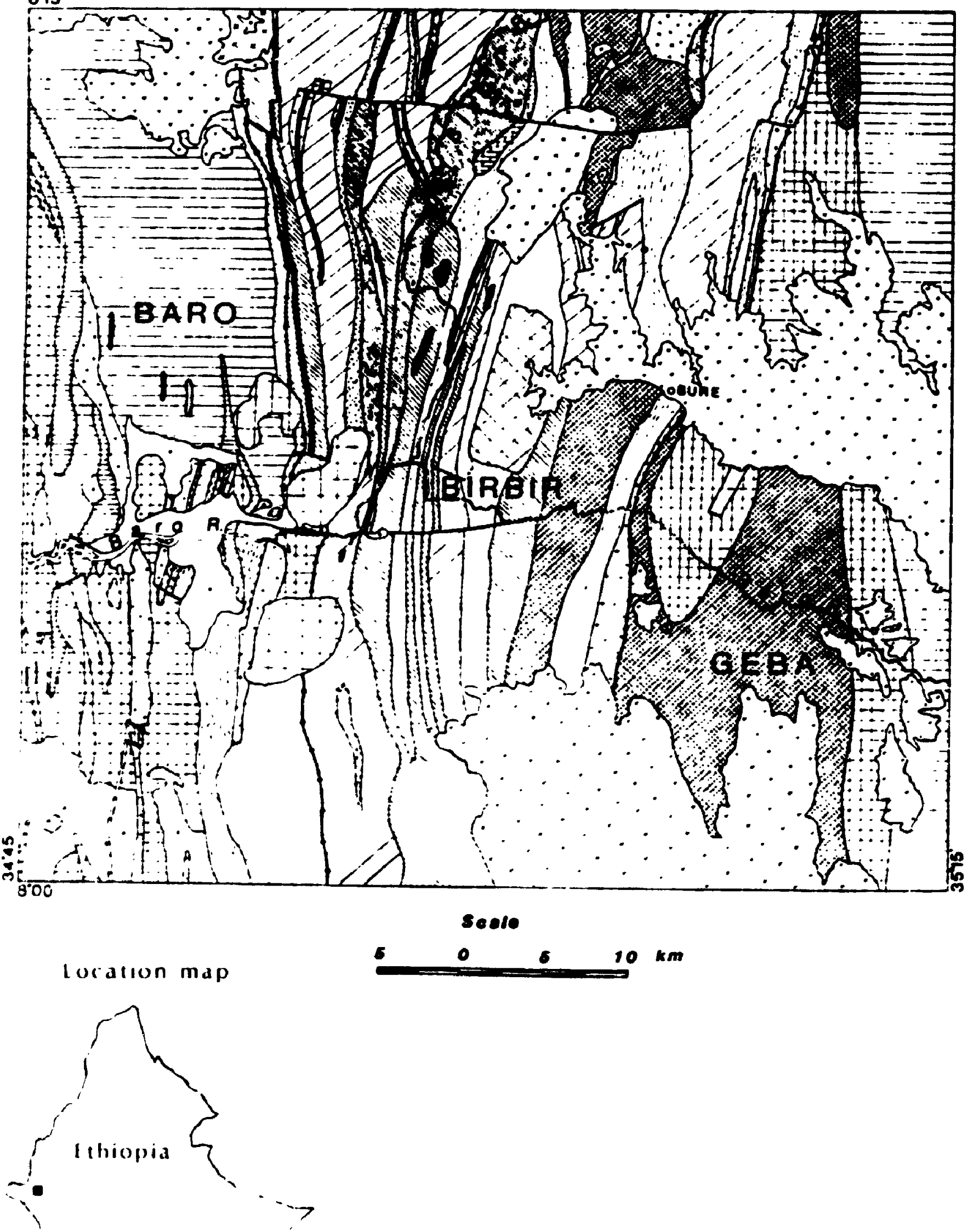
are listed in Table 2.1 and sample localities shown on Figure $2.3^{*}$. Detailed petrographic descriptions for representative samples from the plutons are given in Appendix 1. Typical mineral assemblages of the metasedimentary and volcanic rocks, and gneisses are shown in Table 2.2.

\subsection{META-INTRUSIVE AND INTRUSIVE ROCKS}

\subsubsection{Pre- and/or sya-kinematic plutonic units}

\subsubsection{Bure pluton (mgb)}

The Bure pluton forms an elongate mass, well exposed south of Bure viliage. Here it forms ridges that extend SSW into the Baro River valley (Fig. 2.2). The pluton consists of hornblende gabbro and diorite with minor lenses of talc, chlorite and amphibole schist. The predominant rock is dark grey, fine to medium grained, and equigranular with a color index between 35 and 60 . It shows raint compositional layering. Foliation parallels the contacts and is concordant with foliation in the count, $f$ rocks. Plagioclase laths and hornblende prisms are progressively transformed into lenticles that define the foliation. Primary subhedral-granular and porphyritic textures are locally well-preserved.

In thin section, subhedral-euhedral plagioclase (An $60-70$ ), 0.5 to $4 \mathrm{~mm}$ in length, makes up 30 to $60 \%$ by volume. Hornblende, the principal mafic mineral, can make up to $60 \%$ by volume of the modal minerals. Some hornblende has been partly replaced by fibrous actinolite. Hornblende

\footnotetext{
Figures 2.2 and 2.3 are in the back pocket. map unit names and symbols as on Figure $\mathbf{2 . 2}$.
} 
Table 2.1: Typical modes of representative samples of meta-intrusive and intrusive rocks. Sample localities are given on Fig. 2.3. Modes are based on both point counting and approximate visual estimation.

+ Trace amounts, - absent from modal mineralogy.

\begin{tabular}{|c|c|c|c|c|c|c|c|c|c|c|c|c|}
\hline \multirow{2}{*}{$\begin{array}{l}\text { Locality } \\
\text { Sample No. }\end{array}$} & \multicolumn{2}{|c|}{ Bure } & \multicolumn{2}{|c|}{ Haya } & \multicolumn{5}{|c|}{ Birbir } & \multicolumn{3}{|c|}{ Goma } \\
\hline & ID & 5D & $3 A$ & $7 A$ & $1 G$ & 3G & 96 & 110 & $3 \mathbf{H}$ & $\mathbf{A J}$ & $\mathbf{S J}$ & $7 \mathrm{~J}$ \\
\hline Quartz & 3 & $\cdot$ & 32 & 33 & 20 & 15 & 17 & 16 & 21 & 29 & 28 & 27 \\
\hline Plagioclase & 24 & 36 & 45 & 47 & 47 & 47 & 44 & 50 & 52 & 39 & 37 & 42 \\
\hline K-relds,jar & $\cdot$ & $\cdot$ & 9 & 6 & 8 & 10 & 9 & 7 & 8 & 18 & 19 & 21 \\
\hline Biotite & + & - & 8 & 7 & 11 & 13 & 17 & 13 & 12 & 10 & 11 & 7 \\
\hline Hornblende & 66 & 54 & - & $\cdot$ & 7 & 9 & 8 & 7 & 5 & - & - & - \\
\hline Muscovite & $\cdot$ & - & $z$ & 3 & - & - & - & - & - & - & - & - \\
\hline Epidotc & 4 & $:$ & $=$ & 2 & 4 & 3 & 3 & 4 & 3 & 1 & 1 & 1 \\
\hline Garnct & $\cdot$ & $\cdot$ & - & - & $\cdot$ & $\cdot$ & $\cdot$ & - & - & - & - & - \\
\hline Apatite & + & + & + & + & + & + & + & + & + & + & + & + \\
\hline Allanite & $\cdot$ & $\cdot$ & - & $\cdot$ & - & - & - & $\cdot$ & - & + & - & + \\
\hline Titanite & + & + & + & + & + & + & + & + & + & + & + & + \\
\hline Zircon & $\cdot$ & $\cdot$ & - & - & + & + & + & + & + & + & + & + \\
\hline Calcite & + & + & + & + & - & - & - & - & - & + & + & + \\
\hline Opaques & + & + & - & - & - & - & - & - & - & + & + & + \\
\hline
\end{tabular}


Table 2.1 (continued)

\begin{tabular}{|c|c|c|c|c|c|c|c|c|}
\hline \multirow{2}{*}{$\begin{array}{l}\text { Locality } \\
\text { Sample No. }\end{array}$} & \multicolumn{3}{|c|}{ Baro } & \multicolumn{2}{|c|}{ Mao } & \multicolumn{3}{|c|}{ Bonga } \\
\hline & $A F$ & $8 F$ & $+M$ & 70 & 110 & 6L & $\mathbf{s k}$ & $8 k$ \\
\hline Quartz & 38 & 36 & 39 & $\geq 6$ & 29 & 15 & 32 & 33 \\
\hline Plagioclase & 22 & 18 & 20 & 30 & 28 & 31 & 20 & 22 \\
\hline K-feldspai & 32 & 38 & 33 & 37 & 32 & 42 & 40 & 38 \\
\hline Biotite & 4 & 3 & - & 5 & 4 & 6 & 4 & 4 \\
\hline Hornblende & - & - & - & 1 & 1 & 2 & 2 & 2 \\
\hline Muscovitc & - & $\cdot$ & 5 & - & - & - & - & - \\
\hline Epidote & + & + & - & + & + & - & - & - \\
\hline Garnet & $\bullet$ & - & 3 & - & - & - & - & - \\
\hline Apatite & + & + & + & + & + & + & + & + \\
\hline Allanite & - & - & - & + & + & + & + & + \\
\hline Titanite & + & + & - & + & + & + & + & + \\
\hline Zircon & + & + & + & + & + & + & + & + \\
\hline Calcite & + & + & + & + & + & - & $\cdot$ & $\cdot$ \\
\hline Opaques & + & + & - & + & + & + & + & + \\
\hline
\end{tabular}


commonly occurs as recrystallized granular aggregates, although there are a few euhedral-subhedral phenoclasts. Sericite, epidote and calcite are found along cleavage traces and the margins of plagioclase crystals. Hornblende is commonly chloritized. Quartz, apatite and titanite are accessory minerals. Interstitial magnetite and ilmenite occur sparingly. and some samples contain trace amounts of clinopyroxene and biotite. Biotite, present in the strongly altered samples, has replaced hornblende.

\subsubsection{Haya River pluton (mta)}

Along strike and spatially associated with the Bure gabbro (mgb) is a strongly deformed and metamorphosed pluton made up of tonalite and granodiorite (Fig. 2.2). The pluton, for the most part, is irregular in shape and shows elongarion parallel to the regional NNE structural grain. The internal fabric is highly variable, from weakly to strongly foliated, over a few centimetres to hundreds of metres. Contact relationships with the adjacent rock unit (mvs) are not clear due to the strong degree of deformation.

The main rock type in the Haya River pluton is grey, fine to medium grained, and locally shows pervasive foliation, and compositional layering. The latter consist of amellar aggregates of biotite and muscovite, about $1 \mathrm{~cm}$ thickness, alternating with granoblastic aggregates of plagioclase and quartz, minor microcline, and some garnet.

A granoblastic texture can be seen in thin section. Plagioclase forms 45 to $55 \%$ of the rock, and occurs as anhedral crystals between 2 to $5 \mathrm{~mm}$ in length, commonly altered to sericite, granular epidote and rare calcite. Microprobe analyses of the plagioclase feldspar show reverse zoning with sodic cores $\left(A n_{28}\right)$ and calcic rims $\left(A n_{32}\right)$. Quartz, 0.5 to $3 \mathrm{~mm}$ in size, 
makes up 25 to $30 \%$ of the rock, and occurs mainly as anhedral grains with elongate irregular boundaries. Large grains show undulose extinction and. locally, show a preferred orientation. Anhedral microcline grains, 0.5 to 2 $\mathrm{mm}$ in diameter, constitute up to $10 \%$ of some samples. Biotite, the main mafic mineral, forms flakes 0.5 to $1 \mathrm{~mm}$ long commonly mantled by muscovite. Biotite and muscovite typically occur in association with fine, granular epidote. Euhedral epidote, $<1 \mathrm{~mm}$ across, occurs in close association with biotite and plagioclase. Accessory minerals include apatite and titanite.

\subsubsection{Birbir Intrusive Complex (mqd)}

Rocks of the Birbir intrusive complex occupy the western half of the Birbir Domain, and are deformed to varying degrees in a major north-5outh, ductile, shear zone. Lenticular bodies of quartz diorite, w ith subordinate gabbro, diorite and leucogranitic rocks alternate with narow, heterogencous mylonitic units. Three strongly sheared intrusive sheets, 0.5 to $3 \mathrm{~km}$ wide. alternate with rocks of unit (mvs). The intensity of shearing varies over a few metres: strongly sheared rocks contain less-deformed zones, which retain igneous textures, on the scale of a metre to tens of metres. In the northern part of the map area, rocks of (mqd) grade into predominantly mafic schist and mylonite (mvs). East of the Baro-Birbir River confluence, the quartz diorite forms thin layers of variably sheared rocks, less than a metre to several hundred metres thick, that alternate with abundant, variably deformed, mafic and felsic dykes and sills. To the west, the unit is homogeneous and mylonitization is less severe than in other parts of the Intrusive Complex. The quartz diorite contains elongate xenoliths of microdiorite (Plate 2.1A). 
The main rock type of the Birbir intrusive complex is a grey to dark grey, medium grained, with a well-developed foliation defined by biotite and hornblende streaks, and flattened quartz and plagioclase laths. Mineral lineations, common throughout the pluton, are defined by quartz rods and mafic streaks. In thin-section, the variable degree of deformation is expressed by a wide range of grain sizes, grain boundary types and grain shapes. The rock is composed of andesine - oligoclase, quartz, biotite, $\mathrm{K}$ feldspar, and variable amounts of hornblende and epidote. Accessory minerals include ubiquitous, euhedral apatite, titanite and zircon. Fe-Ti oxides and sulfides occur as inclusions, mainly in biotite and hornblende.

Plagioclase occurs as subhedral or euhedral porphyroclasts, up to $6 \mathrm{~mm}$ in size, and as much smaller anhedral grains in the matrix. The porphyroclasts are commonly fractured and bent, mantled by fine grained crystals, and slightly sericitized. Microprobe analyses of plagioclase show zoning. The cores are calcic $\left(A n_{36-49}\right)$ and the rims sodic $\left(A n_{29-32}\right)$; crystals contain small antiperthitic patches of K-feldspar.

Most quartz and foldspar form a fine-grained, polycrystalline matrix; some quartz grains are flattened parallel to foliation, or make up ribbons wrappe : around feldspar porphyroclasts. Biotite commonly occurs as dark green to brownish green, subhedral plates with bent cleavage traces; it also forms lamellar aggregates molded around porphyroclasts of oriented hornblende and plagioclase. Hornblende forms cuhedral to subhedral, poikiloblastic crystals with well developed pleochroism.

Epidote occurs both as intergranular discrete subhedral to euhedral erystals between biotite, hornblende and plagioclase grains, and as fine granular aggregates resulting from alteration of plagioclase and mafic 
minerals. Euhedral epidote is characteristic of the Birbir (mad) and to a lesser degree, the Haya pluton (mtn). The epidote shows no reaction relationship with other minerals, and is similar to magmatic epidote described by Zen (1985) and Zen and Hammarstrom (1984, 1986). Naney (1981) presented the results of experimental data showing that epidote can crystallize from melts of intermediate composition only at pressures of about $8 \mathrm{k} b$, equivalent to depths of approximately $25 \mathrm{~km}$. Assuming the epidote in the Birbir quartz diorite is magmatic the Bitbir intrusive complex was seemingly formed at deep crustal levels. More detailed investigation would be however required in order to demonstrate conclusively whether.epidote is a primary phase in the Birbir rocks.

\subsubsection{Goma platon (mgd)}

The Goma pluton crops out as a prominent, broad north-trending ridge. rectangular in plan, with dimensions 10 by $4 \mathrm{~km}$. It cuts metamorphosed volcaniclastic rocks, turbiditic wackes and pelites along its northern contact, and gabbroic rocks to the southeast. The pluton is generally massive and is cut by narrow shear zones along its western margin. The contact, where observed, is sharp and the pluton cuts the regional foliation along its northern contact. Foliation of the country rock is deflected around the southwestern corner of the pluton and is truncated by a major shear zone which forms the western boundary of the pluton (Fig. 2.2). The contact relationships between the pluton and country rock indicate that structures occur in the country rock that predate the emplacement of the pluton. The pluton, however, predates the mylonitic foliation.

Fine-grained, mafic xenoliths, $20 \mathrm{~cm}$ to $0.5 \mathrm{~m}$ in size, and mafic 
mineral clots occur locally along the eastern margin. Most are spheroidal and a few are oblate. The xenoliths have sharp margins and no tectonic fabric.

The pluton consists of subhedral-granular, rarely blasto-porphyritic, granodiorite containing plagioclase, $\mathrm{K}$-feldspar, quartz, and minor biotite.

Large (4-6 mm), subhedral-euhedral oligoclase $\left(A n_{15-28}\right)$ laths are zoned and strongly altered to coarse epidote, sericite and chlorite. Locally, quartz occurs as polycrystalline aggregates that show strong undulose extinction. Most K-feldspar occurs as subhedral microcline grains up to $5 \mathrm{~mm}$ across; a few are perthitic, and some poikilitically enclose plagioclase laths. Plagioclase is altered, commonly along cleavage traces, to fine-grained muscovite and granular epidote. Biotite is extensively altered and intergrown with chlorite and $\mathrm{K}$-feldspar. The chlorite is commonly associated with rutile. The latter mineral encloses exsolved opaques with titanite rims. Other accessory minerals include allanite, apatite, titanite, and zircon. Allanite occurs both as euhedral, and some metamict crystals; the latter are corroded and embayed, with discontinuous overgrowths of colourless to yellow anhedral epidote.

\subsubsection{Syn-kinematic granite}

\subsubsection{Garnet-muscovite granite (mgt)}

This intrusive unit is distinctive, although it is not volumetrically important. It forms concordant sheets and pods, from 2 to about $100 \mathrm{~m}$ across, within metagranodiorite that lies along strike from quartz-muscovite schist and conglomerate (ams) at the eastern edge of garnet-sillimanite gneiss (85g) of the Baro Domain (Fig. 2.1). The main rock type is pale 
reddish brown and medium-grained with a characteristic sub-horizontal stretching lineation parallel to the north-south trending structural grain. In places the rock is pegmatitic, and aplitic varieties have also been observed. There is a strong spatial association of these granites with late pegmatitic dykes and veins that clearly crosscut the regional foliation.

The rock contains quartz, microcline perthite, plagioclase $\left(A n_{15}\right)$, muscovite and garnet. Muscovite occurs as euhedral isolated plates, <3 $\mathrm{mm}$ in size; garnets occur both as discrete euhedral grains up to $1 \mathrm{~mm}$ and as small polycrystalline aggregates scattered throughout the rock.

\subsubsection{Baro leucogranite (mgt)}

With in the Baro Domain, sharp crested ridges are underlain by lenticular leucogranite bodies (Figs. 2.1 and 2.2). Observed contacts are parallel to foliation in the country rock, and have gentle dips. The rock is

pink to light gray, medium-grained, generally equigranular, and locally contains enclaves of garnet-bearing, quartzofeldspathic gneiss. One of these intrusive sheets, located $3 \mathrm{~km}$ west of Bonga, is about $200 \mathrm{~m}$ thick and over $6 \mathrm{~km}$ long. It is strongly foliated along its margin, although relict subhedral-granular textures are preserved in its interior. Foliation is defined by biotite streaks as well as flattened quartz and feldspar aggregates.

Thin sections of rocks from this body contain sodic plagioclase (An 3.7 by microprobe analysis), microcline perthite, quartz, minor biotite and hornblende. Accessory minerals include ubiquitous magnetite, ilmenite mantied by leucoxene, haematite, titanite, zircon and apatite. In other similar plutons in the area, magnetite forms the predominant mafic mineral. 


\subsubsection{Late- to post-kinematic plutons}

\subsubsection{Mao pluton (gt)}

The Mao pluton, in the north - central part of the map area, forms an oval-shaped body, $9 \mathrm{~km}$ long and $5 \mathrm{~km}$ wide. It locally exhibits welldeveloped shear bands along its eastern margin and truncates mylonites in units (mss) and (mvs). It contains deformed dioritic xenoliths, and is cut by aplitic dykes and quartz veins. The rock is medium-grained, buff-pink to light grey and consists of plagioclase, microcline, quartz, biotite and minor hornblende. The eastern margin is generally more mafic than the interior parts and is typically coarser grained. The central parts contain large feldspar augen, up to $1 \mathrm{~cm}$ in diameter, surrounded by anastomosing biotite lamellac.

In thin sections, most undeformed samples have a porphyritic to subhedral-granular texture, in which large (5-6 $\mathrm{mm}$ long) subhedral to anhedral microcline and subhedral plagioclase ( n $_{15-20}$ ) grains are surrounded by a matrix of fine-grained, plagioclase, microcline, quartz, biotite and hornblende. Microcline is commonly perthitic, containing fine albite stringers. Plagioclase is associated with marginal myrmekitic intergrowths and rare antiperthite. More deformed samples show quartz and feldspar with undulose extinction, kinked twin lamellae in plagioclase, microcline mantled by fine-grained reerystallized feldspars, sub-grain development in quartz and feldspar and a weak foliation defined by biotite. Biotite and hornblende occur as large discrete grains with ragged margins, and less commonly are poikilitically enclosed within the larger feldspars. Biotite is partially replaced by chlorite, stilpnomelane and opaque minerals, hornblende by chlorite, and feldspars by sericite, epidote and calcite. 


\subsubsection{Bonga pluton (gt)}

This pluton is one of three undeformed, discordant granite stocks that lie along the boundary between the Birbir and Baro domains, north and south of the Baro River (Figs. 2.1, 2.2), ENE of Bonga. It comprises two nested intrusions: a hornblende-biotite granite encloses a quartz monzonite. Intrusive relationships suggest that the core-forming quartz monzonite is the earlier of the two types. The granite contains randomly distributed angular gneissic xenoliths. At its southeastern margin the granite is typically a heterogeneous mix of granodioritic gneiss, intrusive breccia with fragments of gneiss, and homogeneous granite. The southwestern part of the pluton exhibits sharp, discordant contacts. The core-forming quartz monzonite contains abundant rounded mafic xenoliths. Both the xenoliths and the host rock show a Rapakivi texture with $K$-feldspar megacrysts, up $5 \mathrm{~cm}$ in size, mantled by plagioclase (Plate 2.1B). In one locality a quartz-feldspar orbicule, about $20 \mathrm{~cm}$ in diameter, was observed in the quartz monzonite.

The quartz monzonite consists of coarse (up to $4 \mathrm{~cm}$ ), subhedra] microcline perthite phenocrysts, partly mantled by plagioclase, and quartz megacrysts (xenocrysts ?) set in a fine to medium grained matrix of interlocking anhedral quartz, subhedral plagioclase $\left(A n_{22}\right)$, K-reldspar. biotite and hornblende. Accessory minerals include allanite, apatite. magnetite, titanite and zircon. In some cases, feldspar megacrysts partly enclose tabular plagioclase and quartz. The presence of megacrysts in both the xenoliths and the matrix suggests that they are metasomatic in origin.

The pink granite is massive and porphyritic with coarse K-feldspar 
phenocrysts set in a fine- to medium-grained subhedral-granular groundmass; the dominant mineral is microcline perthite followed by quartz, sodic oligoclase ( $A n_{12}$ by microprobe analysis), biotite and hornblende. Accessory minerals include allanite, apatite, titanite and zircon. The plagioclase is altered to sericite, calcite and granular epidote along cleavage traces. Allanite grains are euhedral and zoned.

\subsubsection{Gabbro, diorite and hornbleadite (gb, hbt)}

In the northern part of the study area, west of the Gebari River (Fig. 2.2), circular bodies of relatively undef ormed, mafic rock occur. These consist of medium to coarse-grained, granular gabbro, containing plagioclase, clinopyroxene, orthopyroxene, olivine, hornblende, and Fe-Ti oxides. Zoned plagioclase $(2-4 \mathrm{~mm}$ in size) makes up about $40 \%$ of the modal minerals and is slightly altered to sericite and epidote. The clinopyroxene (augite) is usually in equant granular aggregates with less abundant orthopyroxene and olivine and typically is surrounded by a narrow marginal zone of hornblende. Opaques are mainly skeletal Fe-Ti oxides.

Within the western part of the Birbir complex (mad) there are lenses and dykes of hornblendite and hornblende gabbro (hbt; Fig.2.1) 10-100 m wide. Geologic contacts for unit (gb), particularly in the central and southern part of the area, are approximate as the rocks are difficult to separate from the least-sheared rocks of unit (mad). The virtual absence of deformation in these rocks, their spatial association and mafic composition suggest a genetic relationship between the undeformed gabbro and the dykes. These mafic rocks mark a discrete igneous episode that post-dates any regional deformation. 


\subsection{METAMORPHOSED SEDIMENTARY, VOLCANIC AND HYPABYSSAL} ROCKS; GNEISSES

\subsubsection{Metasedimentary schist (mss)}

These rocks underlie much of the area east of the north-south stretches of the Birbir River, and extend eastward, northwest of Bure where they are overlain by Tertiary basalts. They consist of buff-grey, weakly to strongly schistose, well-preserved metawacke and pelite that underlie the broad valley west of Bure; in areas immediately south of the Mao pluton they are mylonitic. The metasedimentary rocks are interlayered with sheets of mylonitic quartz diorite and biotite-hornblende schist, and are clearly cut by the Mao and Goma plutons. Strong deformation obscures the contact relationships with the mylonitized plutonic rocks.

The typical mineral assemblage of rocks of unit (mss), shown in Table 2.2 is quartz-plagioclase-biotite-muscovite-epidote-calcite. Large porphyroblasts of andalusite (Plate 2.1C) and staurolite, pseudomorphs of cordierite (?) and traces of garnet and graphite occur locally. Lenses of polymictic, poorly-sorted and sub-rounded, matrix-supported coarsc volcaniclastic rocks (Plate 2.1 E) occur in contact with the Goma pluton along its NNE margin. The clasts are mainly rhyolite and andesite. Within unit (mss), marble occurs as thin interlayers, up to $6 \mathrm{~m}$ wide. At one locality, about $4 \mathrm{~km} \mathrm{NW}$ of the Mao pluton, a large body approximately $1 \mathrm{~km}$ wide of fine- to medium-grained crystalline carbonate rock can be traced for at least $3 \mathrm{~km}$.

The metawackes commonly show lenticular structures, mineral lineations, and feldspar augen wrapped by micaceous minerals. Primary sedimentary features such as bedding, cross-lamination, load casts, and graded bedding 
Table 2.2: Typical mineral assemblages of the metasedimentary and volcanic rocks, and gneisses.

\begin{tabular}{|c|c|c|c|c|c|c|c|c|c|c|c|c|c|}
\hline UNIT & $\mathbf{Q z}$ & Pc & comp. & $\mathrm{kI}$ & Bi & $\mathbf{H b}$ & Ep & Mu & $\mathrm{Ch}$ & $\mathbf{T i}$ & Cc & Ox & Others \\
\hline mss & $\mathbf{x}$ & $x$ & ol & $\mathbf{X}$ & $x$ & - & $x$ & $x$ & $x$ & - & - & $x$ & st,ad \\
\hline mvs & $x$ & $x$ & ol-an & $x$ & - & $x$ & $x$ & - & $(x)$ & $x$ & $x$ & $\mathbf{x}$ & $a c, a p$ \\
\hline mvs & $x$ & $x$ & ol & - & $x$ & $x$ & $x$ & $(x)$ & - & - & - & $x$ & \\
\hline mvs & $x$ & $\mathbf{x}$ & 01 & $x$ & $x$ & - & $x$ & $x$ & - & . & $x$ & $x$ & \\
\hline qms & $\mathrm{x}$ & $\mathbf{x}$ & ol & - & $x$ & - & $x$ & $x$ & $x$ & - & - & $x$ & \\
\hline mqs & $x$ & $x$ & ol & $\mathrm{x}$ & $x$ & - & - & $\mathbf{x}$ & - & - & - & $x$ & si \\
\hline csg & $\mathbf{x}$ & $x$ & $01-13$ & $x$ & - & $x$ & $x$ & - & - & $x$ & $x$ & - & $\operatorname{cp}(>10 \%)$ \\
\hline gsg & $x$ & $x$ & ol & $x$ & $\mathbf{x}$ & - & - & $(x)$ & - & - & - & $x$ & $8 \mathrm{~g}, 5 i, c 0,8 \mathrm{~d}$ \\
\hline hbg & $x$ & $\mathrm{x}$ & ol & $x$ & $x$ & $\mathbf{x}$ & $x$ & - & - & - & - & $\mathbf{x}$ & \\
\hline big & $x$ & $x$ & ol & $\mathbf{X}$ & $x$ & $x$ & - & - & - & $x$ & - & $x$ & \\
\hline
\end{tabular}

NB: $X$ : major mineral (>10\%); $x$ : minor mineral $(<10 \%)$ ( $x)$ : retrograde mineral

Mineral abbreviations: Qz, quartz; Pc, plagioclase: Kr, K-feldspar: Bi, biotite; Hb. hornblende; Ep. epidote; Mu, muscovitc; Ch. chloritc; Ti, titanite: Cc, calcitc: Ox, oxide: ol, oligoclasc: an, andesinc:

1a. Labradorite: gd, anthophyllite (gedrite); ga, garnct; co, cordierite: si, sillimanite: sc, scapolite: ap. apatite: cp. clinopyroxene. 
are common (Plate 2.1C). The sedimentary structures indicate that turbidity flows have been responsible for some of the sediments. Associated coarse volcapiclastic rocks sugsest rapid deposition in a shallow water environment close to an area being uplifted and rapidly eroded. The slight rounding of the clasts may require subaerial transport and/or shoreline abrasion and imply a subaerial volcanic source area. The predominance of wackes and absence of sedimentary rocks of continental origin sugsest that the succession is similar to that found in present-day, intra-oceanic island arc environments (Mitchell and Readin8, 1978).

\subsubsection{Metarolcanic schist and mylonite (mvs)}

In the flat-lying area east of the Birbir River, metavolcanic rocks and mylonites occur between sheets of metaquartz diorite (mad) and metasedimentary rocks (mss), on the scale of hundreds of metres thickness. North and south of Bure, metavolcanic rocks, mainly basic in composition,

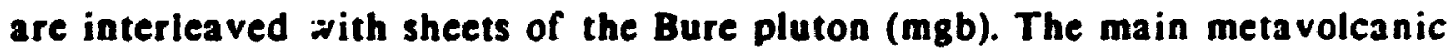
rock is a fine-, to medium-grained, hornblende/actinolite-plagioclaseepidote-calcite schist, commonly interlayered on a centimetre to metre scale with minor quartz-muscovite-sericite, and actinolite schists. Primary igneous textures include amygdules (Plate 2.1D) and plagioclase laths and hornbleade phenocrysts in rocks of andesitic composition. Most mylonitic rocks have a lenticular structure, commonly with mineral lineation. Near the Baro-Birbir river confluence, mafic and felsic dykes cut the unit and these are disrupted by shearing. de Wit (1977) interpreted these rocks as part of a dismembered sheeted-dyke complex, while others have attributed them to multiple dyke injection synchronous with shearing (S.K. Hanmer and J.M. Moore, pers. comm. 1987). 


\subsubsection{Garnet-sillimanite guelss (gss), calc-sillicate gnelss (csg) and muscovite bearing gseiss (ass)}

The garnet - sillimanite aneiss unit underlies the area east of the Bonga River (Fig. 2.2). It consists of interlayered aluminous and calcsilicate gneisses and subordinate amphibolite. The main exposures occur near Bonga village and consist of sillimanite and/or garnet-bearing layers, up to tens of metres thick, associated with grey to pink biotite gneisses and schists. The sillimanite-bearing rocks commonly contain fibrolitic knots, a few centimetres in diameter, of intergrown sillimanite quartz and plagioclase (Plate 2.1F), and large garnet porphyroblasts. Locally, garnets up to $5 \mathrm{~cm}$ in diameter constitute as much as $60 \%$ of the rock and are intergrown with quartz, biotite, and sillimanite. Cordierite-orthoamphibole (gedrite)-bearing rocks are interlayered with the sillimanite-garnet-biotite gneisses. East of unit (gsg), a narrow belt of muscovite-bearing gneisses (msg) occurs that probably represents a downgraded equivalent of unit (big) to the west.

East of Bonga, along the eastern boundary of the sillimanite gneiss, is a well-exposed section of calc-silicate gneiss (csg). The rock is fine- to medium-grained, green-grey, weakly foliated, and commonly layered on a centimctre-scale. Mineral assemblages in these rocks include garnet-epidotehornblende-diopside, garnet-epidote-microcline-biotite, and biotiteplagioclase-hornblende with epidote-rich bands (epidosite).

\subsubsection{Quartz - muscovite schist and conglonerate (qus)}

This unit, forming a NNE-trending wedge that lies to the east of the muscovite-bearing gneiss (msg), consists of quartz-muscovite schist with 
rare garnet and staurolite(?), in addition to subordinate layers of quartzite. Some of these rocks are chlorite-rich. The predominant lithology is fine- to medium-grained, leucocratic schist. containing quartz and plagioclase, with minor microcline and variable amounts of muscovite (520\%). Thin section examination shows a clastic texture. A lens of quartzpebble conglomerate, containine pebbles up to $2 \mathrm{~cm}$ in diameter within the quartz-muscovite schist suggests a clastic origin for rocks of unit (qms).

\subsubsection{Blotite gaciss (bis) and horableade-blotite gnelss (hbs)}

Most of the area west of Bonga consists of layered and non-layered gneisses.Dominant rock types are strongly foliated, pink to light gray. medium-8rained biotite and horablende-biotite gneisses. Quartzoreldspathic gneisses with minor quartzite and amphibolite layers also occur within the (hbg) unit. The gneisses typicully consist of plagioclase, microcline, quartz, biotite and hornblende. locally with traces of muscovite and garnet. Relationships between associated rock types, particularly the intercalations of amphibolite and thin quartzite iayers, are obscured by strong deformation. Some of the biotite and hornblende-biotite gneisses are migmatitic and are cut by aumerous sub-concordant lenses of granitic and pegmatitic material. Discordant layers and pods of pegmatite also occur. A consistent and appropriate mineralogical composition suggest that these rocks are predominantly tonalitic or granodioritic orthogneisses. 
Plate 2.1: Structural and metamorphic features of some map-units from the Birbir $(A, B, C)$ anui Baro domains (D).

A- Mafic xenoliths in Birbir quartz diorite (mqd). Main road, $10 \mathrm{~km} \mathrm{E}$ of Bonga (Fig. 2.2). Small divisions on scale card are centimetres.

B- Rapakivi texture in post-kinematic quartz monzonite, core of Bonga pluton (gt), I km north of Baro River. p: plagioclase, f: K-feldspar.

C. Cyclic layering of mudstone and wacke in unit (mss) showing graded bedding. Truncated cross-laminac are top indicators shown by the direction of arrow; large andalusite crystals have grown in pelitic layers. There is a weak cleavage at $-25^{\circ}$ to the layering. One kilometre north of main road, $11 \mathrm{~km}$ west of Bure. Pen magnet is 12 cm long.

D- Andesitic flows (mvs) containing flattened quartz amygdules (am). Two kilometres north of main road, $10 \mathrm{~km}$ west of Bure.

E- Coarse volcaniclastic rock (mss) viewed on surface perpendicular to lineation. ve = flow banded rhyolitic clast. Main road, $9 \mathrm{~km}$ west of Bure.

F- Sillimanite-quartz nodules in unit (8sg) near the eastern boundary of the Baro Domain with the Birbir Domain. Hammer handic $50 \mathrm{~cm}$ long, lies on foliation plane, parallel to shallow lineation. Three kilometres north of Baro River, $2 \mathrm{~km}$ east of Bonga. 

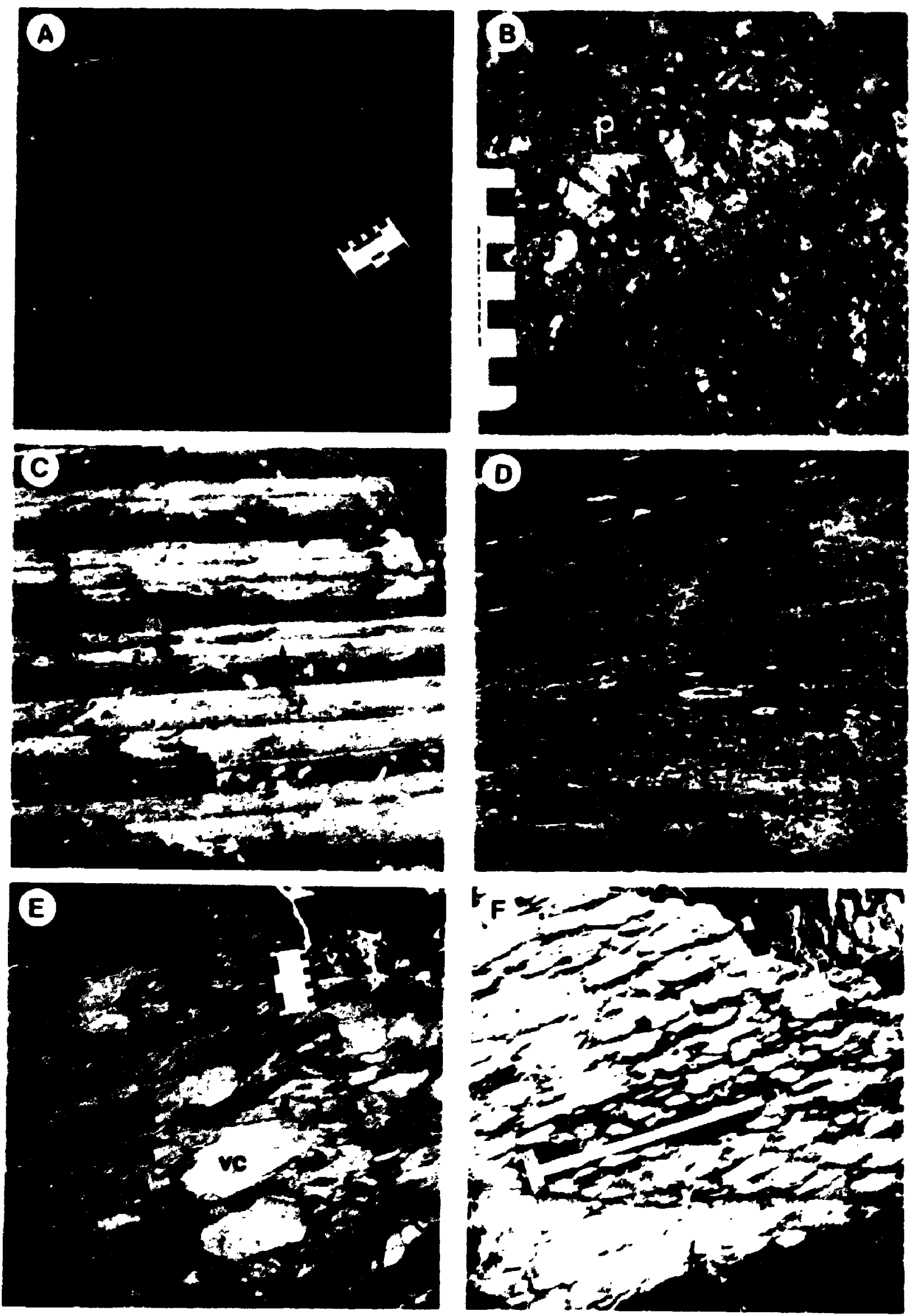
Plate 2.2: Some aspects of metamorphic mineral assemblages in pelitic rocks ( $A, B)$; and strain features in Birbir Shear Zone $(C$, D, E, F).

A- Asscmblagc almandine-cordieritc-gedritc-sillimanite from unit (gsg) of the Baro Domain. cd: cordierite, s: sillimanite, gd: gedritc, g: garnet. PPL. Scalc bar is $0.5 \mathrm{~mm}$ long. Sample \#UP49a, locality: Bonga.

13- Staurolite porphyroblasts in finc-giained matrix of quartz, biolite, muscovite and chlorite in unit (mss). st: staurolite. cl: Fe-rich chloritc, b: biotitc. PPL. Scalc bar is $1 \mathrm{~mm}$ long. Sample \# OY032, locality: $11 \mathrm{~km}$ west of Burc.

C. Flattencd mafic xenolith in weakly to moderately foliated Birbir quartz diorite (mqd). Ductilc shear zonc at top (s) truncates $x e n o l i t h$ and has sinistral sense. Main road $10 \mathrm{~km}$ east of Bonga. Pen magnet is $12 \mathrm{~cm}$ long.

1)- Mylonitic extension lincation in (mad) defincd by aggregates of hiotite and quartz. parallel to pen. Birbir River, $5 \mathrm{~km}$ north of conlluence with Baro River.

F- Well-defincd mylonitic foliation in metagranodiorite (mgd) defined by biotite and hornblende streaks, and rlattened quartz and feldspar. sb: shear bands, indicating sinistral shcar sensc. Two kilometres north of main road, $11.5 \mathrm{~km}$ west of Burc.

1. Folded mylonitic foliation in Birbir quartz diorite (mqd). Onc kilumetre north of main road. $12 \mathrm{~km}$ west of Burc. 


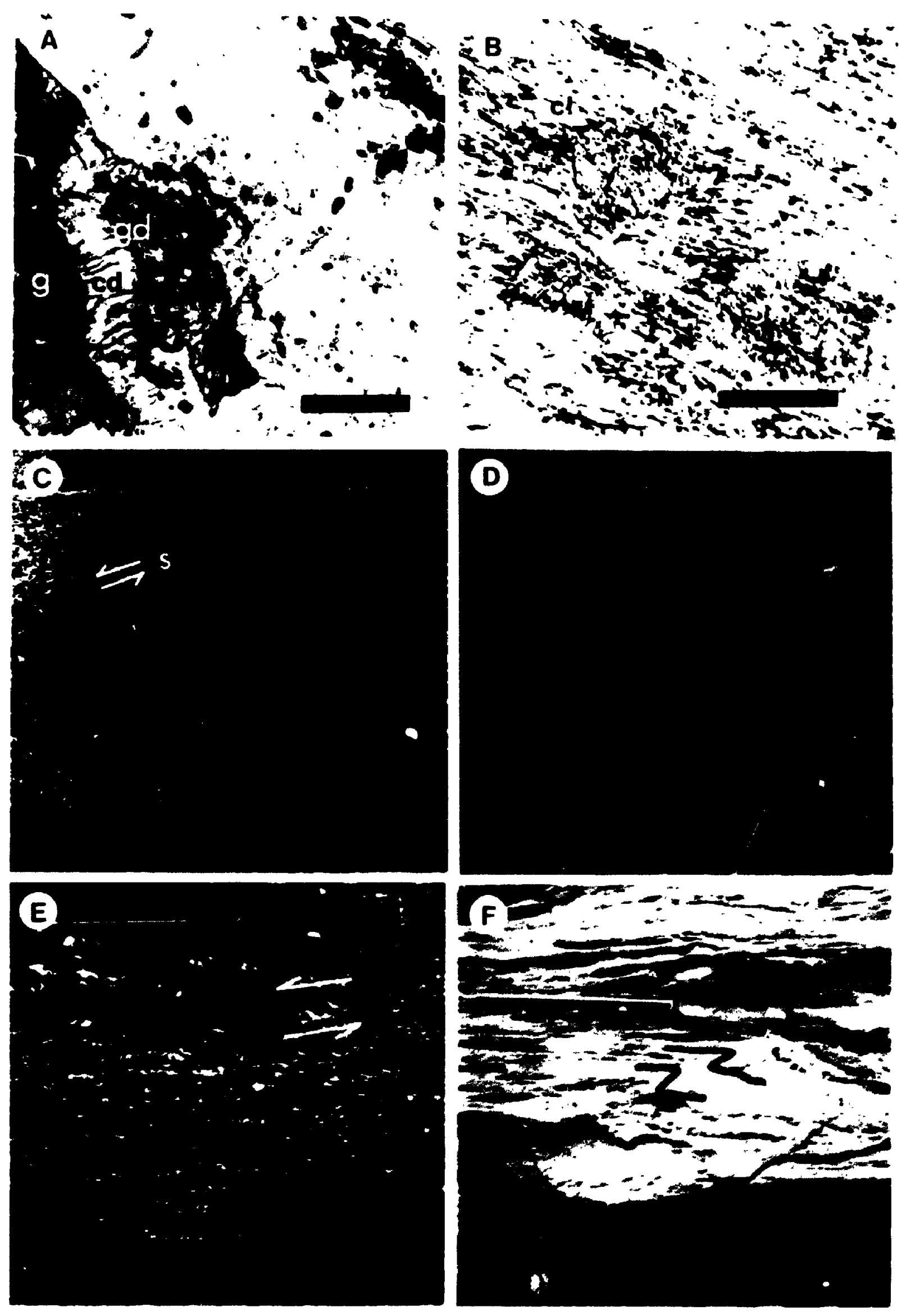




\subsection{METAMORPHISM}

\subsubsection{Mineral parageneses and P-T conditions}

Several diagnostic metamorphic mineral assemblages have been identified in the aluminous and calc-silicate rocks of units (gsg) and (csg) along the eastern margin of the Baro Domain. These include:

1) sillimanite-garnet(almandine)-cordierite-orthoamphiboleplagioclase-biotite-quartz

2) sillimanite-K feldspar-biotite-quartz

3) sillimanite-garnet (almandine)-K feldspar-biotite-quartz

4) hornblende-clinopyroxene (diopside)-epidote-titanite

Assemblages (1) and (2) define a very restricted PT range for the peak metamorphic conditions that affected the metasedimentary schist and gneiss unit ( 858 ). Assemblage (1) indicates a reaction isograd:

1) sillimanite + orthoamphibole (gedrite) = garnet (almandine) + cordierite + vapour (or liquid)

Part of a reaction grid developed by Carmichacl (1985) for Fe-Mg rich pelites in a six component system: $\mathrm{SiO}_{2}-\mathrm{Al}_{2} \mathrm{O}_{3}-\mathrm{FeO}-\mathrm{MgO}_{\mathrm{N}} \mathrm{Na}_{2} \mathrm{O}-\mathrm{K}_{2} \mathrm{O}$ (without sufficient $K$ to form muscovite), has been used to interpret this reaction isograd. The reaction is univariant and occurs at pressures between $5.8-7.0 \mathrm{~kb}$ and temperatures between $630-730^{\circ} \mathrm{C}$ (Fig. $2.4 \mathrm{a}$ ). The absence of muscovite from asseniblages (2) and (3) shows that peak metamorphic temperatures were above the reaction isograd:

2) muscovite + quartz = sillimanite + microcline + water 
Figure 2.4: Petrogenetic grid (after Carmichael, 1985) showing reactions among assemblages that contain biotite, plagioclase and quartz observed in metasedimentary schists and gneisses ( 858 ) of the Baro Domain (A), and metapelites (mss) of the Birbir Domain (B).

Stippled areas indicate range of possible P-T conditions for observed asscmblages and dots indicate invariant points.

Mincral abbreviations
$\mathrm{A} \quad \mathrm{Al}_{2} \mathrm{O}_{5}$
ky kyanitc
and andalusite
sill sillimanite
C cordicrite
Ch chlorite
G garnet
Gd gedritc
K K feldspar
$L$ granitic liquid
$M$ muscovite
$P$ orthopyroxene
$S$ staurolite
$V$ vapour 


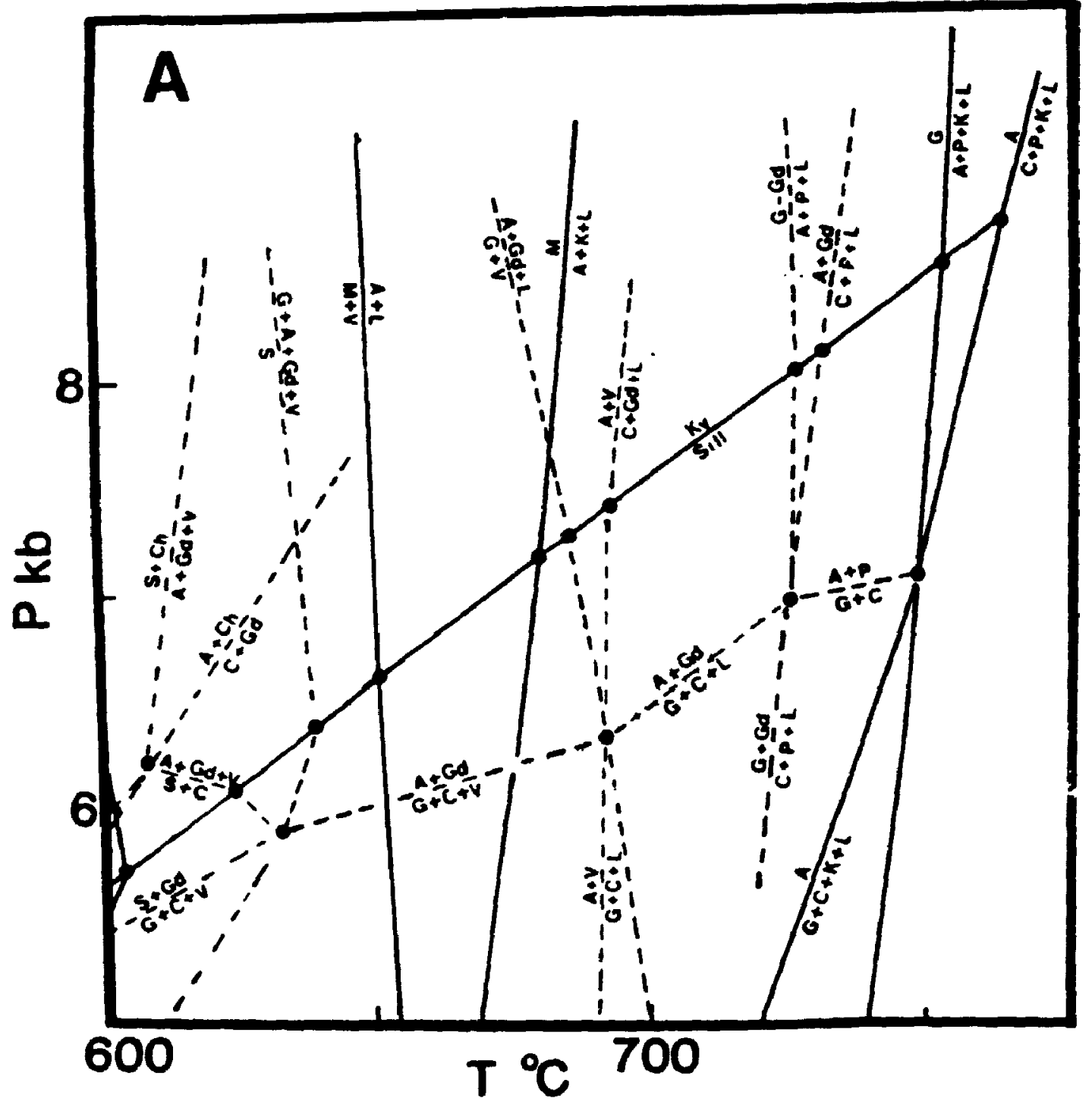

Sillimanite + Cedrite $=$ Carnet $($ Alm. $)+$ Cordierite + Water 


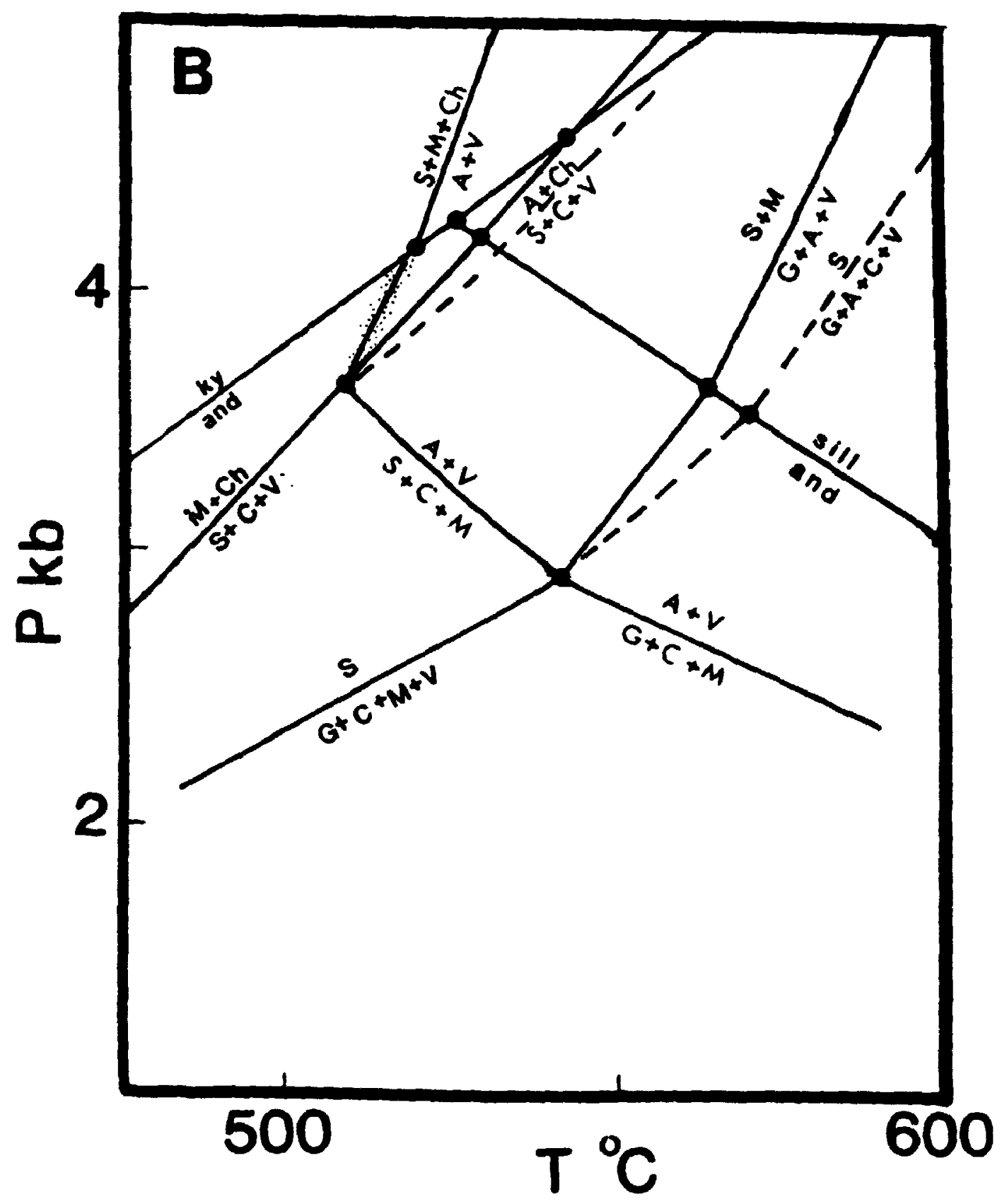


The reaction, in combination with (1), restricts conditions of formation of the aluminous rocks to within $680.730^{\circ} \mathrm{C}$ and $6.3 \cdot 7.0 \mathrm{~kb}$ (Fg. 2.4a). The minerals shown in assemblage (3) possibly formed by a continuous reaction where K-feldspar appears over a range of temperatures (Ramberg. 1952). The reaction is as follows:

3) biotite + sillimanite + quartz = garnet (almandine) + K-feldspar

The presence of muscovite-bearing assemblages in unit (qms), from the eastern side of the Baro Domain, indicates an increase in metamorphic grade towards the west where muscovite-f ree, sillimanite-bearing assemblages prevail. The sillimanite-free, muscovite-bearing assemblages of unit (qms) have primary clastic textures suggeiting they are not retrograde assemblages from unit (gsg).

In rocks of unit (gsg) containing assemblage (1), some garnet porphyroblasts contain quartz inclusions with an orientation that is continuous with foliation in the matrix. Such observations suggest a lateor syn-tectonic period of garnet growth with respect to foliation associated with the main deformation. Orientation of some of the orthoamphibole (gedrite) and sillimanite in the direction of the main foliation indicates that these minerals grew during the development of the gneissic fabric (Plate 2.2A); the growth of garnet porphyroblasts outlasted the deformation.

The origin of the bulk composition associated with assemblage (1) is interesting because of the high content of Mg-and Fe-rich minerals in these rocks. Three competing views are held. The first is that the rocks reflect the premetamorphic bulk composition. The second explanation involves 
metasomatic addition of $\mathrm{MgO}+\mathrm{FeO}$ and simultaneous removal of $\mathrm{CaO}$ and alkalies, while the third involves enrichment of $\mathrm{MgO}+\mathrm{FeO}$ by metamcrphic differentiation or anatexis. In the third alternative, $\mathrm{MgO}$ and FeO would have migrated from rocks undergoing granitization and concentrated near relicts of amphibolite and calc silicate rocks (Ramberg, 1952; Moorhouse. 1969). This may be brought about by strong penetrative deformation or by partial melting. Because of migmatization in the area and the presence of anatectic granites, enrichment in Fe and $\mathrm{Mg}$ may be a direct consequence of metamorphic differentiation and anatexis.

Metamorphic mineral assemblages from units (mss) and (mvs) of the Birbir Domain include:

1) quartz-muscovite-biotite-plagioclase-epidote-calcite

2) quartz-muscovite-biotite-staurolite-andalusite-chlorite $+1 \cdot$ garnet, and

3) quartz-oligoclase-microcline-hornblende-biotite-epidote $+/$ - actinolite, assemblages that indicate lower amphibolite (epidote-amphibolite) facies metamorphism. Rocks with assemblage (2) contains large porphyroblasts of andalusite and staurolite co-existing with biotite, muscovite and Fe-rich chlorite.

Staurolite occurs as well-formed euhedral, sieve-textured, porphyroblasts, partly replaced by a fine-grained mixture of quartz. feldspar, biotite and muscovite (Plate 2.2B). Chlorite occurs as rims around 
staurolite and also independently in the matrix. Both staurolite and andalusite overgrew the foliation and contain inclusions of quartz and biotite flakes that are continuous with the foliation in the matrix. A concentric overgrowth around andalusite consists of muscovite followed by chlorite with a few fine-grained staurolite crystals. The assemblage implies a reaction isograd involving biotite, plagioclase and quartz:

1) staurolite + chlorite + muscovite = andalusite + biotite + quartz + water

The appropriate part of a petrogenetic grid constructed by Carmichael (1985) is shown in Figure 2.4b. The reaction is univariant at constant $\mathrm{H}_{2} \mathrm{O}$ activity; it has taken place within the andalusite stability field at temperature of about $520-530^{\circ} \mathrm{C}$ and $3.5-4.1 \mathrm{~kb}$ pressure.

The meta-igneous rock assemblages and sheared equivalents of the Birbir Domain can be represented by the association of quartz-microcline-oligoclase -biotise-hornblende-epidote-titanite, without chlorite, that broadly indicates epidote-amphibolite facies metamorphism. Metamorphic conditions associated with the mylonitic rocks and those virtually unaffected by the shearing thus both reflect lower amphibolite facies metamorphism and su. rest that metamorphic conditions may not have changed throughout the duration of shearing. Nevertheless, the presence of actinolite after hornblende, and minor chlorite veinlets in the mylonitic rocks indicate limited retrograde effects during the shearing event. 


\subsection{STRUCTURE}

\subsubsection{Geelsale terranes}

In the map area, the gneissic terranes consist of the Baro Domain to the west, and the Geba Domain to the east. Rocks of the Baro Domain contain planar structures with a general NNW strike and moderate dips of $30-60^{\circ}$ to the east and west; locally they may be subvertical. Linear features plunge gently north or south. An exception to the latter occurs in an area immediately west of the Birbir Domain at the northern end of the map area. where lineations plunge moderately toward the east and down the dip of foliation. A foll pattern expressed by foliation directions (Fig. 2.2), is truacated with abrupt change in foliation patterns that coincides with changes in the attitudes of linear features mentioned above. The truncated fold pattern shows what appears to be a detached limb of a fold but could not be verified on the ground and no structural line can be drawn between the rocks of the Bare and Birbir Domains.

At least two stages of deformation can be documented in rocks of the gneissic terranes. The earliest is defined by a well-developed gneissic layering and penetrative mineral foliation. In rocks of unit (gsg), garnet porphyroblasts and sillimanite (fibrolite) overgrew the fabric suggesting that metamorphism outlasted regional deformation. Intra-folial folds related to this deformation are recognized in migmatites.

A second deformation resulted in kilometre-seale rolds in the foliation of the earlier deformation. Foliation attitudes mapped west of Bonga and seen on aerial photographs suggest a major antiform with kilometre scale wavelength and a north-south trending axial-surface irace. Crenulation and 
weak mineral lincations are developed with gentle northerly plunges, parallel to the axis of the inferred fold. The crenulation is probably related to the second deformation.

One of the Baro leucogranite sheets shows an upright, open fold pattern. The sneissic fabric and lenticular shape of the granite sheets suggest that they are either pre- or syn-tectonic relative to the first generation of structures. Similar granite sheets are found further to the south, and Davidson (1983) described them as having tectonic contacts related to thrusting. Granitoid pegmatites cut the main fabric and all are undeformed.

In the eastern part of the map area, gaeisses of the Geba Domain also show pronounced layering and foliation. A major antiform at the western margin of the Geba Domain has been truncated against rocks of the Birbir Domain. The contact is marked by a mylonitic metagranite sheet (mgt).

\subsubsection{Birbir Domaie}

Rocks of the Birbir Domain have predominantly north-south - striking foliations and typically dip steeply to the east or west. Sedimentary structures such as cross-lamination and graded bedding are well preserved in the metagreywacke (mss). In the area just west of Bure, bedding-cleavage intersections $\left(S_{0} / S_{1}\right)$ at several localities give way-up directions consistent with those indicated by sedimentary structures, all of which indicate casterly younging. Most bedding and cleavage are subparallel.

Whitten (1969) discussed cleavage-bedding parallelism and suggested three main mechanisms of formation: 1) the development of foliation parallel 
to axial planes of recumbent isoclinal folds 2) the development of foliation by minerals growing with preferred orientation along some pre-exisi:ng flane (eg. bedding planes or shear planes), the result of solutions percolating through the rock and 3) the rare development of foliation within incompetent units interlaminated between competent ones during flexural- slip folding. The second of these explanations is preferred by the author where foliation $\left(S_{1}\right)$ developed subparallel to bedding $\left(S_{0}\right)$ during shearing.

The development of the major fabric in rocks of the Birbir Domain was followed by a pericd of porphyroblast development. Rocks of unit (mss) contain staurolite and andalusite porphyroblasts that overgrew the foliation. The porphyroblasts contain aligned inclusions that suggest that their growth post-dated the development of the major pla:ar fabric.

\subsubsection{Blrbir Shear Zone (BSZ)}

The western half of the Birbir Domain is characterized by a NNEstriking transcurrent fault system consisting of numerous mylonite zones separated by less-strained rocks. These zones occupy an area at least $15 \mathrm{~km}$ wide, and are collectively termed the Birbir Shear Zone (BSZ; S.K. Hanmer and J.M. Moore, pers. comm. 1986). The rocks affected by the thearing commonly have extension lineations that plunge gently to the north or south suggesting transcurrent movement (Plate 2.2D). Dips of the mylonitic foliation are typically steep to vertical (Plate 2.2 C,E). Rocks of unit (mvs) show mylonitic foliation which is locally a crenulation of pre-existing cleavage; the mylonitic foliation is asymmetrically folded in places (Plate 2.2F). The crenulation may suggest more than one generation of shearing. although it could be produced as a continuum in one major shearing event. 
Structures in the BSZ suggest emplacement of abundant mafic and felsic dykes synchronous with deformation (S.K. Hanmer, pers. comm., 1986). Most of the mafic dykes were emplaced in a plane oblique, either clockwise or anticlockwise, to the mylonitic foliation. The former are shortened, producing lozenge-shaped fragments, while those disposed anticlockwise are symmetrically boudined/extended in their own plane. Veins are also emplaced into either quadrant, suggesting dextral shear combined with shortening across the shear plane. A sinistral sense of movement can be identified from the displacement of late felsic dykes at several localities and rotated feldspar augen, on the eastern contact of the Mao pluton, that clearly cut the earlier mylonitic foliation. The BSZ, therefore, was initiated with dextral movement that subsequently converted to sinistral movement.

Stccessive stages of mylonitization are observed in the BSZ. Plutonic units within the Birbir Domain are variably deformed within the shear zone. Shearing is most extreme in the Birbir quartz diorite complex, where rocks range from protomylonite 'n mylonite; rocks of the Goma and Mao plutons are protomylonitic. Shear foliation and lineation are expressed by quartz rods and hornblende and biotite aggregates.

The Birbir quartz diorite sheets show a wide variety of grain sizes, grain boundary types and grain shapes on a very local scale. It is possible on the basis of petrographic studies to typify samples in order of decreasing shear strain:

(1) Rocks of high strain (Plate $2.3 \mathrm{~F}$ and $\mathrm{G}$; samples $\# 2 \mathrm{G}, 8 \mathrm{H}, 2 \mathrm{I}$; see Fig. 2.3 for localities). These are composed of a fine-grained lepidoblastic matrix of quartz, feldspar, biotite and hornblende $(>80 \%)$ that contains 
Plate 2.3: Photomicrographs showing various stages of mylonitization of unit (mqd) in the Birbir shear zone (ABCDEFG); and some textures and mineralogy in other intrusive units. PiL, XPL: under plane and crossed polarized light respectively. Scale bar is $1 \mathrm{~mm}$ for $2.3 \mathrm{~A}$ and $\mathrm{G}, 0.5 \mathrm{~mm}$ for $2.3 \mathrm{BCDEFIII}$. Sample localities are given in Figure 2.3 .

A. Subhedral-granular texturc, shcwing curved to slightly cmbayed grain boundaries of plagioclase laths, unoriented biotite and hornblende, and interstitial quartz. XPL. Sample \# TH.

B- Ben! and kinked plagioclase (p) showing twin iamellac; microrractures and zones of sericitization run at right angles to the twin lamellac. XPL. Sample $\# T I H$.

C- Plagioclase phenoclasts ( $p$ ) showing deformation twins and subgrain development, mantled by recrystallized quartz (q) and feldspar. XPL. Sample \# T5G.

D- Granoblastic quartz (q) and leldspar (f) with plagioclase (p) phenoclasts showing straight grain houndaries and triple junctions. $X P L$. Samplc $\#$ T3G.

E- Biotitc (b) and hornblende (h), cuhcural cpidote (c), titanite 4 l, and interstitial quartz (q) delining mylonitic loliation. PPl. Sample $\#$ T5G.

F. Polygonized quartz ribbons (q) around K-feldspar porphyroclasts (f). Note that the feldspar shows drawn-out tails indicating dextral sense of shear. XPL. Sample $\neq T 8 H$.

G- C.S fabric shown by microcrystalline aggregates of recrystallized feldspar and quartz in $>80^{\%} \%$ fine matrix. Shear foliatuon $C$ is defined by traces of matrix layers. XPL. Samn!c = OY 107. locality: $5 \mathrm{~km}$ northeast of the Baro - Birbir Rivers confluence.

H- Garnet-muscovite granite of Baro Domain (mgt). g: garnct, ms: muscovitc, $m$ : microclinc, q: quartz. p: plagioclasc. PPL. Samplc \# T4M, locality: $7.5 \mathrm{~km}$ cast of Bonga.

1- Large biotite erystals cnelosing cuhcural zircons (z) in Bonga granitc (gt). m: microclinc. XPL. Sample $=T 5 K$, locality: $7 \mathrm{rm}$ cas of Bonga. 


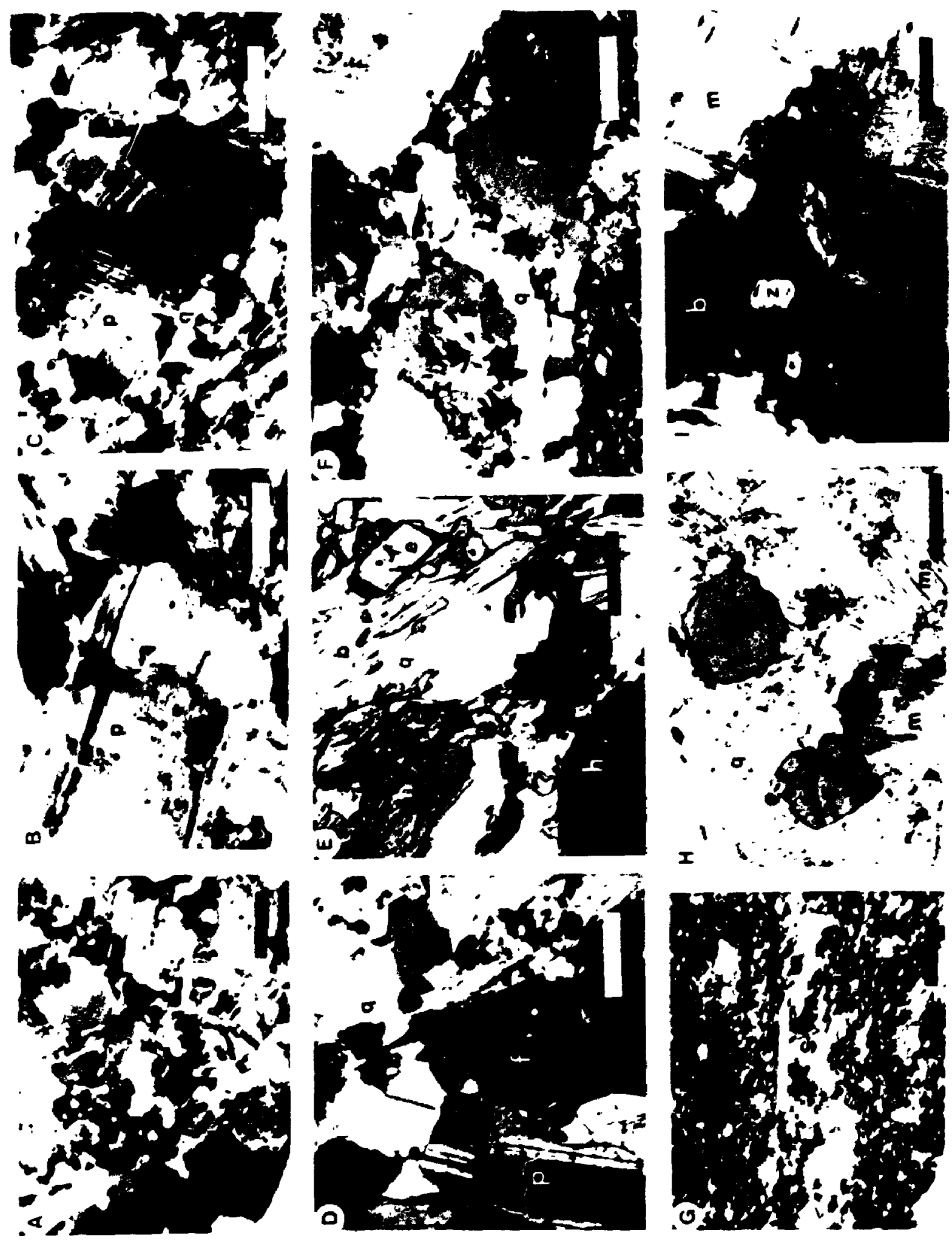


phenoclasts of plagioclase and hornblende (10-20\%). The rocks are considered mylonites or ultramylonites (Sibsor, 1977; Berthe et al., 1979). Plagioclase laths up to $5 \mathrm{~mm}$ are commonly bent and contain strain-induced albite and pericline twin lamellae. Some are mantled by very fine-grained feldspars. Some of the plagioclase phenoclasts have recognizable tails, formed by very fine-grained crystals, that can be used to determine the sense of shear. As biotite constitutes about $15 \%$ of the rock, a large part of the strain imposed through shearing was probably taken up by grain boundary sliding. As a result, some hornblende and plagioclase phenoclasts were relatively unaffected and survived shearing. Shear foliation is mainly defined by alignment of biotite flakes, and oriented hornblende and plagioclase phenoclasts. This orientation is probably a result of rigid body rotation. Fine-grained quartz and feldspar are polygonized and locally ribboned into strain-free grains that make up the bulk of the matri Deformation in these rocks seems to be essentially a product of ductile processes involving recrystallization and recovery.

(2) Rocks with intermediate strain (Plates $2.3 \mathrm{C}, \mathrm{D}$ and E; Samples $\# 3 G$, 5G, 9I). These rocks display similar strain features to those described above but have sub-equal proportions of matrix (composed of quartz, feldspar, biotite, hornblende and epidote) and phenoclasts (plagioclase and hornblende). Granoblastic quartz and feldspar show undulatory extinction.

(3) Least strained rocks (Plate $2.3 \mathrm{~A}$ and $\mathrm{B}$; samples $\# 9 \mathrm{G}, 1 \mathrm{H}, 4 \mathrm{I}$ ). These rocks are coarse grained, contain well-preserved igneous textures such as subhedral-euhedral plagioclase and hornblende phenocrysts, unoriented biotite plates that tend to occur in clots, and perthite, antiperthite and 
myrmekite.

The protomylonite stage is represented by (3), mylonites by (2) and (1) and ultramylonite stage by (1). In the last, a small proportion of phenoclasts remain in the fine-grained matrix.

Evidence for non-penetrative internal deformation in the Goma and Mao plutons is shown by narrow shear zones, that are well-developed near the contacts of the plutons. Both ductile and brittle shear strain are seen in samples from the western contact of the Goma pluton. The strain features include undulose extinction in quartz and to a lesser extent in feldspars, feldspar phenoclasts mantled by fine-grained recrystallized grains along weak deformation bands, and microf ractures in plagioclase phenoclasts, now filted by stringers of secondary minerals.

\subsection{DISCUSSION}

The present study reveals that the rocks of the Birbir Domain are bounded by tectonites. The western margin of the Birbir Domain is defined by a major shear zone; the eastern boundary is also marked by mylonite and by truncation of foliation patterns that define a map-scale antiform in the Geba Domain (Fig. 2.2). Deformation within the Birbir Domain has produced penetrative foliation and schistosity that run sub-parallel to thuse of the gneissic terranes. An apparently coeval regional deformation thus appears to have affected rocks of both the and Baro and Geba high-grade gneissic terranes and the Birbir lower-grade terrane. 
Several shear zones, striking generally north-south, occur within rocks of the Birbir Domain and also separate relatively low-grade rocks of the Birbir Domain on the east from the high-grade schists and gneisses of the Baro Domain to the west. Andalusite - bearing pelitic schists (mss) indicate low-pressure facies metamorphism (Miyashiro, 1973), whereas sillimanite - K feldspar - orthoamphibole assemblages to the west indicate medium-pressure high temperature facies metamorphism. The pelitic mineral assemblages in rocks of the Birbir Domain indicate low-amphibolite grade whereas the Baro and Geba domains have attained metamorphic grade of upper almandineamphibolite facies. The change in metamorphic grade is observed in samples obtained within a strike-normal distance of about 4 kilometres suggesting an abrupt increase in metamorphic grade across the transcurrent fault system of the Birbir Shear Zone (BSZ). The metamorphic gradient is probably too steep to be accounted for by exposure of more deeply buried rocks by tilting. and there are no faults in the area that suggest vertical displacements. The two domains thus appear to have been tectonically juxtaposed.

Older east - west isocilinal recumbent folds documented in gneisses of the Geba valley outside the Geotraverse area (Kazmin et al., 1979; Teferra and Berhe, unpublished) have not been seen in the Baro Domain. Along the north-west frontier between Ethiopia and the Sudan, however, Warden and Horkel (1984) identified east-west trending folds from satellite imagery. There is little evidence to correlate the Baro and the Geba domains, but the presence in both of more than one generation of deformation, similar grade of metamorphism and their tectonic relationship with the lower-grade rocks all indicate that both are composed of reworked rocks, possibly pre- Pan- 
African in age. Intense deformation along north-south Pan-African structures coupled with recrystallization may have obliterated any earlier metamorphic mineral assemblages and structures. 


\section{CHAPTER 3}

\section{PETROCHEMISTRY}

\subsection{GENERAL STATEMENT}

Chemical analyses of seven plutons from the Gore-Gambella Geotraverse are used to (1) classify the intrusive rocks (2) infer their petrogenetic history and (3) evaluate the tectonic envirnaments in which the magmas were generated. The averages and ranges of element abundances and CIPW norns of each pluton are listed in Table 3.1 to 3.4. Average abundances of some trace elements are compared to Le Maitre's (1976) average values for some igneous rocks and Taylor's (1979) and Taylor and McLennan's (1985) average values for continental crust (Table 3.5).

\subsection{GEOLOGICAL SETTING}

The Baro and Geba domains consist of high-grade heterogeneous orthoand paragneisses and migmatites, whereas the Birbir Domain comprises lowergrade wackes, pelites, volcanic and plutonic rocks covering a wide compositional spectrum. Field relations, lithology and structural style of plutons in the Birbir and Baro domains can be used to divide these rocks into three groups: 1) pre- and/or syn-kinematic mafic and intermediate intrusive units 2) syn-kinematic leucogranite sheets and 3) late-to postkinematic granitoid rocks. Rocks of Group (1) and (3) occupy the Birbir Domain and are metamorphosed and deformed to various degrees within the Birbir Shear Zone (BSZ). Deformation is most extreme in rocks of Group (1). The rocks range from protomylonite to mylonite and show steep mylonitic foliation and sub-horizontal extension lineation. Group (2) rocks are 
Table 3.1: Average and range of chemical composition and CIPW norms of the low-K suite (21 samples) (rom Group (1) compared to analyses from the compilation by Le Maitre (1976). $\mathrm{FeO}_{(\mathrm{T})}$ is total iron: An\% is average anorthite content of plagioclase feldspar; $n$ is number of analyses

$\begin{array}{lcc}\text { Bure } & \text { Haya } & \text { Le Maitre's } \\ (n=12) & (n=9) & \text { average }\end{array}$

\begin{tabular}{|c|c|c|c|c|c|c|}
\hline & Average & Rangc & Average & Range & Gabbro & Tonalitc \\
\hline $\begin{array}{l}\mathrm{SiO}_{2} \\
\mathrm{TiO}_{2} \\
\mathrm{Al}_{2} \mathrm{O}_{3} \\
\mathrm{Fe}_{2} \mathrm{O}_{3} \\
\mathrm{MnO} \\
\mathrm{MgO}_{8} \mathrm{O} \\
\mathrm{CaO} \\
\mathrm{Na}_{2} \mathrm{O} \\
\mathrm{K}_{2} \mathrm{O} \\
\mathrm{P}_{2} \mathrm{O}_{5}\end{array}$ & $\begin{array}{r}50.12 \\
0.65 \\
14.00 \\
9.24 \\
0.18 \\
9.54 \\
11.92 \\
1.99 \\
0.43 \\
0.07\end{array}$ & $\begin{array}{c}46.17-55.29 \\
0.07-1.23 \\
8.33-22.13 \\
4.52-12.29 \\
0.06-0.25 \\
4.70-14.25 \\
5.44-19.44 \\
0.08-3.94 \\
0.03-1.61 \\
0-0.21\end{array}$ & $\begin{array}{r}71.82 \\
0.14 \\
15.93 \\
1.55 \\
0.06 \\
0.55 \\
3.60 \\
4.81 \\
1.26 \\
0.04\end{array}$ & $\begin{array}{c}69.35-73.53 \\
0.07-0.19 \\
14.24-17.41 \\
1.21-1.85 \\
0.05-0.06 \\
0.32-0.70 \\
2.35-4.57 \\
4.45-5.07 \\
0.96-1.63 \\
0.02-0.06\end{array}$ & $\begin{array}{r}50.14 \\
1.12 \\
15.48 \\
10.63 \\
0.12 \\
7.59 \\
9.58 \\
2.39 \\
0.93 \\
0.24\end{array}$ & $\begin{array}{r}61.52 \\
0.73 \\
16.48 \\
5.65 \\
0.08 \\
2.80 \\
5.42 \\
3.63 \\
2.07 \\
0.25\end{array}$ \\
\hline Total & 98.14 & & 99.81 & - & 99.15 & 100.01 \\
\hline $\begin{array}{l}Q \\
C \\
\text { Or } \\
\text { Ab } \\
\text { An }\end{array}$ & $\begin{array}{r}0.86 \\
- \\
3.37 \\
21.06 \\
36.02\end{array}$ & $\begin{array}{cl}0-4.31 \\
- \\
0.18 & -9.63 \\
6.14 & -33.72 \\
23.97 & -49.00\end{array}$ & $\begin{array}{r}30.12 \\
0.32 \\
7.45 \\
40.70 \\
17.26\end{array}$ & $\begin{array}{cc}26.39 & -33.70 \\
0 & -1.03 \\
5.67 & -9.63 \\
37.66 & -42.90 \\
11.53 & -22.35\end{array}$ & $\begin{array}{c}0.71 \\
\cdot \\
5.49 \\
20.26 \\
28.60\end{array}$ & $\begin{array}{c}16.62 \\
- \\
12.24 \\
30.67 \\
22.58\end{array}$ \\
\hline $\begin{array}{l}\text { Ne } \\
\text { Di } \\
\text { Hy }\end{array}$ & $\begin{array}{r}0.09 \\
13.09 \\
4.73\end{array}$ & $\begin{array}{cc}0 & -0.44 \\
1.21 & -21.42 \\
0.15 & -13.01\end{array}$ & $\begin{array}{l}- \\
0.29 \\
2.39\end{array}$ & $\begin{array}{r}0-2.35 \\
1.78-2.78\end{array}$ & $\begin{array}{c}- \\
13.70 \\
22.13\end{array}$ & $\begin{array}{l}- \\
1.49 \\
9.68\end{array}$ \\
\hline OI & 7.52 & $0-20.21$ & - & - & - & $\cdot$ \\
\hline $\begin{array}{l}\text { Mt } \\
\text { II }\end{array}$ & $\begin{array}{l}3.14 \\
1.21\end{array}$ & $\begin{array}{ll}2.35 & -4.00 \\
0.14 & -2.36\end{array}$ & $\begin{array}{l}0.75 \\
0.27\end{array}$ & $\begin{array}{ll}0.58 & -0.89 \\
0.13 & -0.36\end{array}$ & $\begin{array}{l}4.36 \\
2.13\end{array}$ & $\begin{array}{l}2.66 \\
1.40\end{array}$ \\
\hline $\begin{array}{l}C r \\
A p\end{array}$ & 0.06 & $0.02-0.13$ & $\dot{0.09}$ & $0.05-0.14$ & 0.56 & 0.58 \\
\hline$A \cap B_{0}$ & 68 & $62-78$ & 29 & $23-35$ & - & - \\
\hline
\end{tabular}


Table 3.2: Average and range of chemical composition and CIPW norms of the calc-alkaline suite (43 samples) from Group (1) compared to analyses from the compilation by Le Maitre (1976).

Birbir

$(n=29)$

Average Range Average

$\mathrm{SiO}_{2} \quad 59.50$

$\mathrm{TiO}_{2} \quad 0.72$

$\mathrm{Al}_{2} \mathrm{O}_{3} \quad 16.89$

$\mathrm{Fe}_{2} \mathrm{O}_{3} \quad 7.19$

Mino 0.13

$\mathrm{MgO} \quad 3.00$

$\mathrm{CaO} \quad 6.00$

$\mathrm{Na} 2 \mathrm{O} \quad 3.71$

$\mathrm{K}_{2} \mathrm{O} \quad 2.28$

$\mathrm{P}_{2} \mathrm{O}_{5} \quad 0.17$

Tolal 99.59

Q $\quad 11.24$

Or $\quad 13.46$

Ab $\quad 31.38$

An

Di

Hy

Mit

II

Ap

An\%

$\begin{array}{cr}55.22-63.89 & 59.50 \\ 0.53-0.91 & 0.46 \\ 15.61-18.96 & 15.43 \\ 5.04-8.77 & 2.95 \\ 0.09-0.18 & 0.08 \\ 1.95-4.35 & 0.93 \\ 3.81-7.79 & 2.23 \\ 3.36-4.67 & 5.13 \\ 1.38-3.91 & 3.25 \\ 0.09-0.31 & 0.13\end{array}$

100.09

$$
2.04-15.46
$$

$8.16 \cdot 23.11$

28.43-39.52

12.55-27.39

1.46-9.47

$6.01-14.44$

2.43-3.49

$1.01-1.73$

$0.21-0.72$

$26-47$

19.48

19.21

43.61

8.89

0.72

4.11

1.62

0.87

0.30

18
1.44

42
Goma

$(n=16)$

$67.38-71.47$
$0.29-0.59$
$14.48-16.55$
$2.29-4.31$
$0.06-0.12$
$0.62-1.22$
$1.87-2.73$
$4.18-5.75$
$2.64-4.04$
$0.06-0.19$

Range Diorite

57.48

0.95

16.67

3.93

0.12

3.71

6.58

3.54

1.76

0.29

99.98
Le Maitre's

Granodiorite 66.09

0.54

15.73

4.11

0.08

1.74

3.83

3.75

2.73

0.18

99.90

22.30

16.11

31.73

17.34

-

7.40

2.00

1.03

0.42 average

Adamellise

6865

054

$1+55$

7.42

0.08

1.14

2.68

347

4.00

0.09

100.05

25.17

23.66

2936

11.55

0.03-1.41

12.56

1.11-2.08

3.63

$\begin{array}{ll}0.55-1.12 & 1.80 \\ 0.14-0.44 & 0.68\end{array}$

$\begin{array}{ll}0.55-1.12 & 1.80 \\ 0.14-0.44 & 0.68\end{array}$

14-20
5.66

1.79

1.03

0.20 
Table 3.3: Average and range of chemical composition and CIPW norms of Group (2) plutonic units compared to analyses of S-type granites of White and Chappell (1983).

Baro
$(n=10)$
$(n=10)$

\begin{tabular}{|c|c|c|c|c|c|}
\hline & Average & Range & Average & Range & $\begin{array}{l}\text { S-type } \\
\text { granite }\end{array}$ \\
\hline $\mathrm{SiO}_{2}$ & 75.57 & $73.01-78.73$ & 74.62 & $72.73-75.59$ & 69.08 \\
\hline $\mathrm{TiO}_{2}$ & 0.18 & $0.10-0.34$ & 0.02 & $0.01-0.07$ & 0.55 \\
\hline $\mathrm{Al}_{2} \mathrm{O}_{3}$ & 12.06 & $10.50-13.61$ & 14.55 & $13.85-14.98$ & 14.30 \\
\hline$F e()(T)$ & 2.75 & $1.59-3.53$ & 0.87 & $0.39 \cdot 1.03$ & 3.96 \\
\hline $\operatorname{MnO}$ & 0.04 & $0.01-0.09$ & 0.18 & $0.01-0.32$ & 0.06 \\
\hline MgO & 0.12 & $0.02-0.17$ & 0.13 & $0.02-0.20$ & 1.82 \\
\hline $\mathrm{CaO}$ & 0.42 & $0.05 \cdot 0.96$ & 0.64 & $0.41 \cdot 0.74$ & 2.49 \\
\hline $\mathrm{Na} O{ }_{2}$ & 3.32 & $2.27 \cdot 4.11$ & 4.02 & $3.59-4.48$ & 2.20 \\
\hline $\mathrm{K}_{2} \overline{\mathrm{O}}$ & 5.38 & $4.88-6.58$ & 4.53 & $4.14-5.09$ & 3.63 \\
\hline $\mathrm{P}_{2} \mathrm{O}_{5}$ & 0.01 & $0-0.01$ & 0.02 & $0-0.04$ & 0.13 \\
\hline Total & 99.85 & & 99.58 & & 98.22 \\
\hline $\mathbf{Q}$ & 34.68 & & 33.15 & & \\
\hline Or & 31.86 & & 25.82 & & \\
\hline$A b$ & 28.13 & & 37.38 & & \\
\hline An & 1.51 & & 3.35 & & \\
\hline C & 0.60 & & 1.55 & & \\
\hline Di & 0.21 & & 0 & & \\
\hline Ity & 0.10 & & 0 & & \\
\hline Mit & 1.83 & & 0.55 & & \\
\hline II & 0.05 & & 0.01 & & \\
\hline Ap & 0.02 & & 0.02 & & \\
\hline$A n^{\prime \prime} \%$ & 5 & & 8 & & \\
\hline
\end{tabular}


Table 3.4: Average and range of chemical composition and CIPW norms of Group (3) plutons compared to analyses from the compilation by Le Maitre (1976) and A-type granites of White and Chappell (1983).
Mao
Bonga
$(n=10)$
$(n=13)$
Le Malitre's
Average

\begin{tabular}{|c|c|c|c|c|c|c|}
\hline & Average & Range & Average & Range & Granite & $\begin{array}{l}\text { A-type } \\
\text { granite }\end{array}$ \\
\hline $\begin{array}{l}\mathrm{SiO}_{2} \\
\mathrm{TiO}_{2} \\
\mathrm{Al}_{2} \mathrm{O}_{3} \\
\mathrm{FeO}_{(\mathrm{T})} \\
\mathrm{MnO} \mathrm{T} \\
\mathrm{MgO}_{\mathrm{g}} \mathrm{O} \\
\mathrm{CaO} \\
\mathrm{Na}_{2} \mathrm{O} \\
\mathrm{K}_{2} \mathrm{O} \\
\mathrm{P}_{2} \mathrm{O}_{5}\end{array}$ & $\begin{array}{r}70.12 \\
0.43 \\
14.24 \\
3.97 \\
0.08 \\
0.60 \\
1.79 \\
3.95 \\
4.74 \\
0.12\end{array}$ & $\begin{array}{c}68.95-73.09 \\
0.13-0.52 \\
13.97-14.66 \\
2.20-4.36 \\
0.06-0.09 \\
0.19-0.70 \\
0.81-2.14 \\
3.71-5.14 \\
4.18-4.97 \\
0.01-0.16\end{array}$ & $\begin{array}{c}75.18 \\
0.14 \\
12.72 \\
2.16 \\
0.03 \\
0.08 \\
0.85 \\
3.27 \\
5.35 \\
-\end{array}$ & $\begin{array}{c}72.35-79.10 \\
0.10-0.24 \\
10.41-13.40 \\
1.62-3.15 \\
0.02-0.05 \\
0.06-0.21 \\
0.69-1.12 \\
2.74-3.58 \\
4.14-5.93 \\
-\end{array}$ & $\begin{array}{c}71.30 \\
0.31 \\
14.32 \\
2.85 \\
0.05 \\
0.71 \\
1.84 \\
3.68 \\
4.07 \\
0.12\end{array}$ & $\begin{array}{c}73.60 \\
0.33 \\
12.69 \\
2.71 \\
0.06 \\
0.33 \\
1.09 \\
3.34 \\
4.51 \\
0.09\end{array}$ \\
\hline Total & 100.04 & & 99.78 & & 100.07 & 98.75 \\
\hline $\begin{array}{l}Q \\
\text { Or } \\
\text { Ab } \\
\text { An } \\
\text { C } \\
\text { Di } \\
\text { Hy } \\
\text { MII } \\
\text { II } \\
\text { Ap }\end{array}$ & $\begin{array}{c}24.69 \\
27.88 \\
31.48 \\
8.18 \\
- \\
0.81 \\
2.98 \\
2.87 \\
0.88 \\
0.37\end{array}$ & & $\begin{array}{r}30.58 \\
34.08 \\
28.43 \\
4.21 \\
0.03 \\
0.25 \\
0.16 \\
0.39 \\
0.17 \\
0\end{array}$ & & $\begin{array}{r}29.06 \\
24.50 \\
31.13 \\
8.04 \\
0.92 \\
- \\
3.37 \\
1.75 \\
0.58 \\
0.28\end{array}$ & \\
\hline$A_{n} \%$ & 19 & & 12 & & & \\
\hline
\end{tabular}



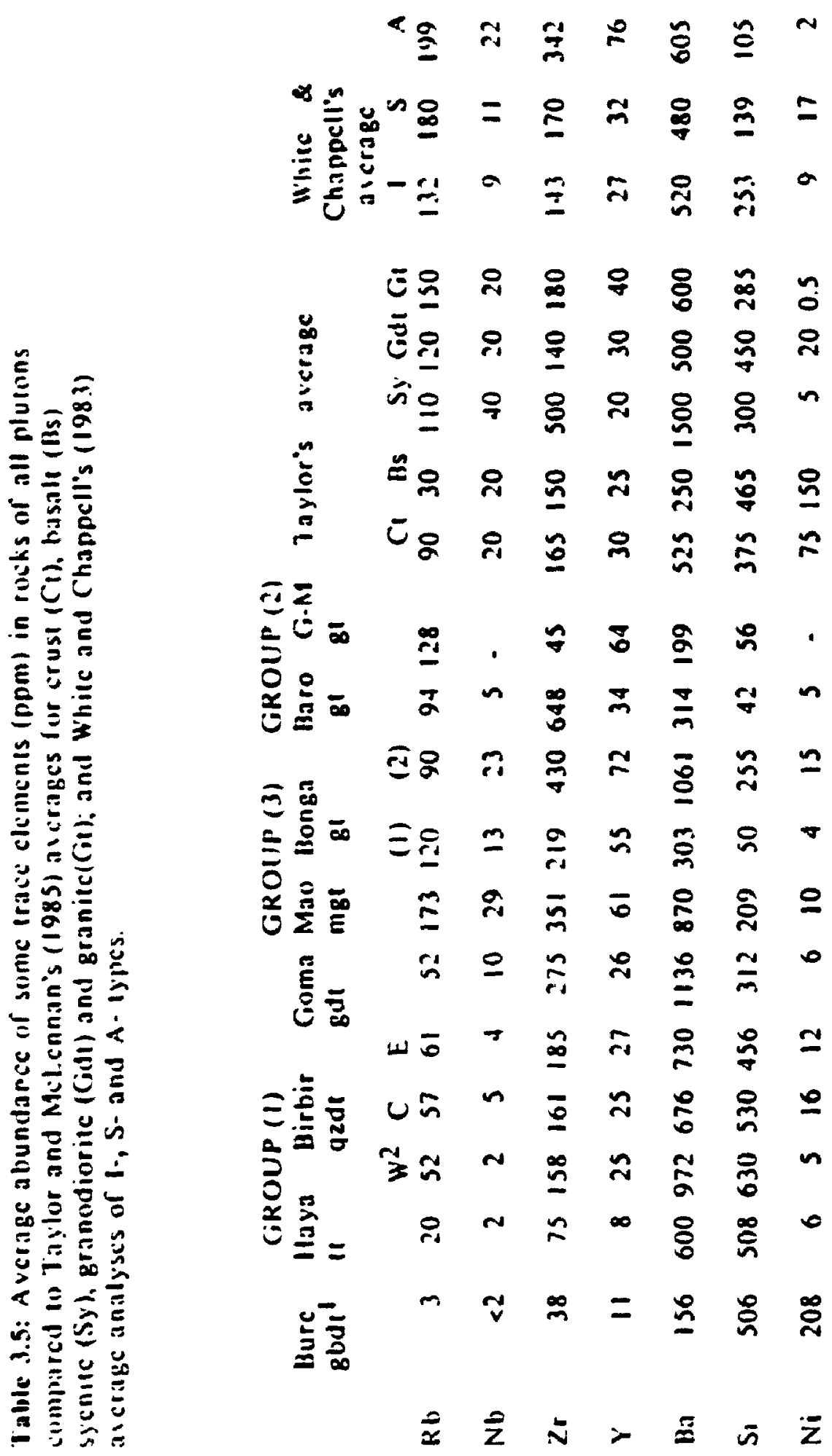

E유 \&

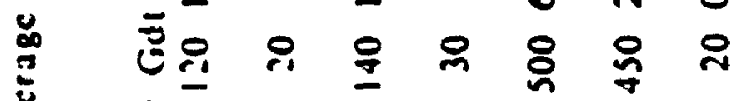
ن்유유 융 8 n

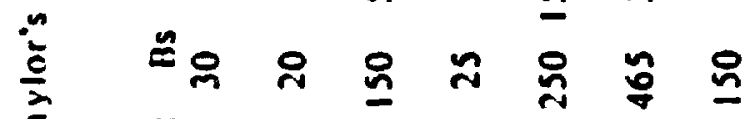

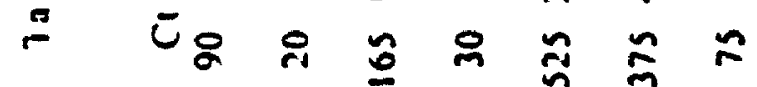

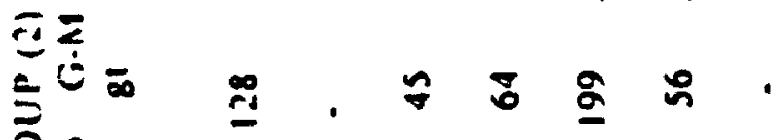

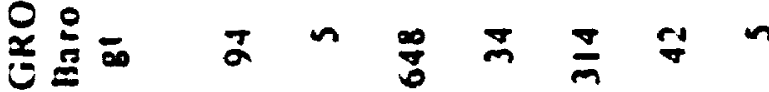

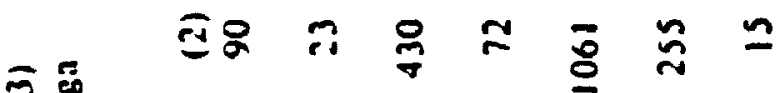

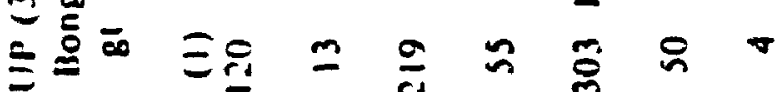

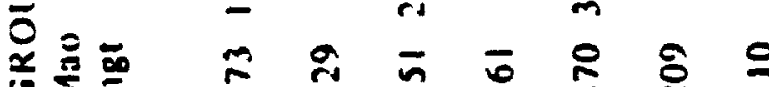

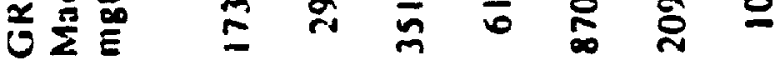

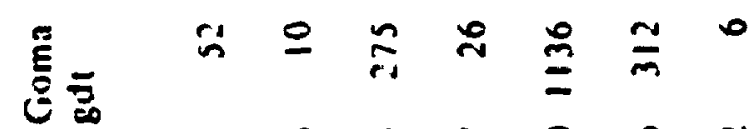
亦

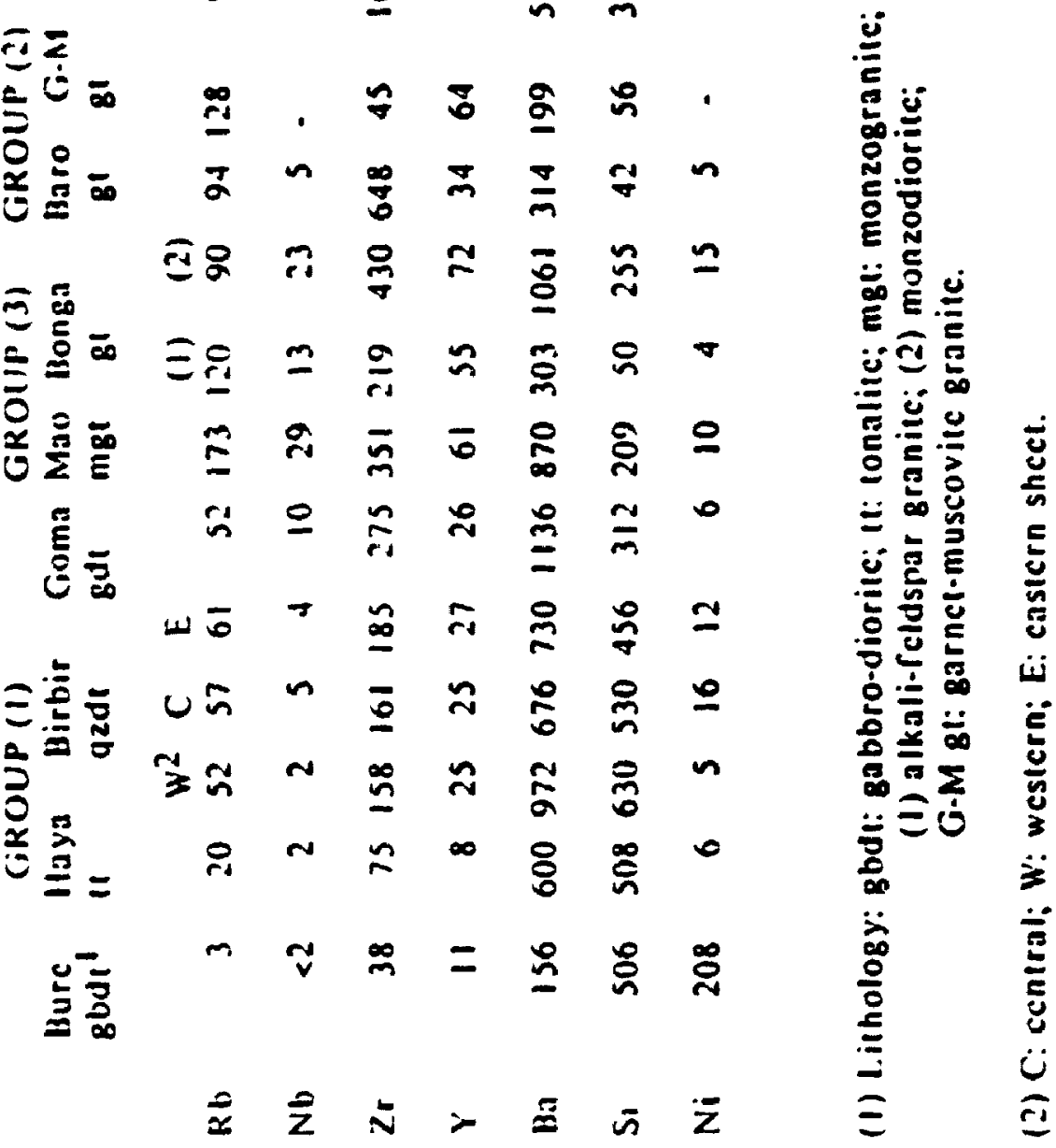




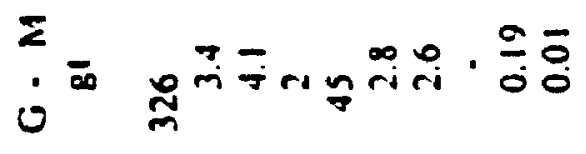

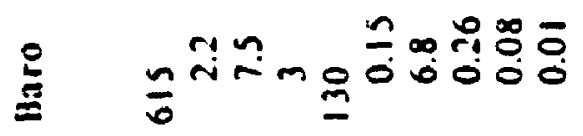

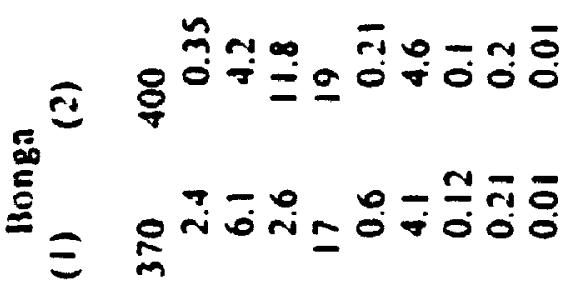

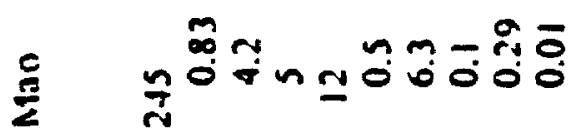

E 을

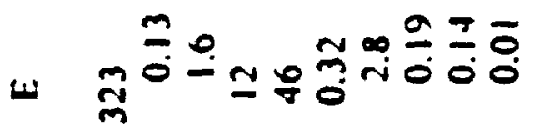

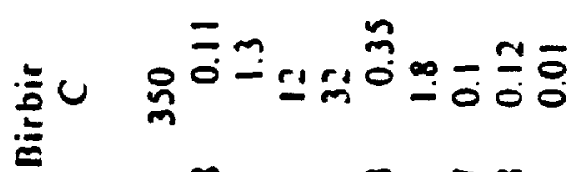

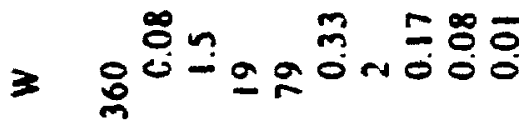

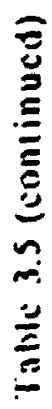

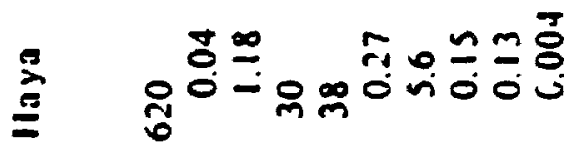

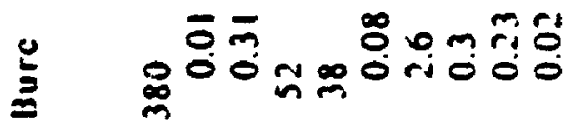

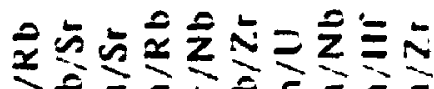

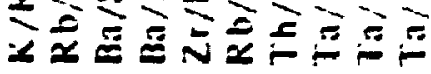


strongly deformed, and form lenses and sheets within the high-grade rocks of the Baro Domain. Plutons of Group (3) occtpy the Birbir Domain and its western boundary with rocks of the Baro Domain. These are circular, discordant and generally undeformed.

\subsection{SAMPLING AND ANALYTICAL METHODS}

A total of 120 rock samples were collected of which 106 were analyzed for major ard some trace elements. Between 2 and $3 \mathrm{~kg}$ of fresh chips were collected. Weathered surfaces were removed, and the fresh material pulverized in a jaw crusher. A representative sample, made by coning and quartering, was then crushed to $<100$ mesh using a Bleuler Mill (shatterbox).

Major elements as well as $\mathrm{Ba}, \mathrm{Cr}, \mathrm{Zr}, \mathrm{Sr}, \mathrm{Rb}, \mathrm{Y}, \mathrm{Nb}, \mathrm{Ni}$ and $\mathrm{V}$ were determined by XRF spectrometry using a Philips PW 1410/20 AHP instrument at the University of Ottawa. Fused-glass pellets were prs:ared according to the methods of Norrish and Hutton (1969). One gram of powdered sample was mixed with $5 \mathrm{gm}$ of $\mathrm{Li}_{2} \mathrm{~B}_{7} \mathrm{O}_{4}$ and $0.3 \mathrm{gm} \mathrm{LiF}$, and fused to a glass pellet within a platinium holder. Accuracy was estimated by analysing reference standard samples DR-N and GS-N. Results are given in Appendix 2, Tables A2.1 and A2.2. CIPW normative calculaticns and various cartesian and triangular plots were made using the BMDP and IGPET programs.

Abundances of the rare earths La, Ce, Nd, Sm, Eu, Tb, Dy, Ho, Er, Yb and Lu as well as Sc, Co, Sb, Cs, Hf, Ta, W, Th and U from 10 samples were measured by instrumental neutron activation (INAA) in the Department of Nuclear Engineering. Ecole Polytechnique in Montreal and the data are given 
in Appendix 2, Table A2.3. The compositions of plagioclase, K-feldspar. biotite, hornblende, apatite, epidote, muscovite and garnet were determined at Carleton University using a Cambridge Microscan 5 electron microprobe (Appendix 3).

\subsection{ALTERATION AND METAMORPHISM}

The extent to which regionally metamorphosed igneous rocks have behaved as closed systems is unknown. For mylonitic rocks "open" vs "closed" system behaviour is even more difficult to assess because fluid transport along microscopic slip planes causes localized selective enrichment and depletion of some elements. Despite the known mobility of some elements, however, many studies present data from meta-igneous rocks that show closed-system behaviour and reveal magmatic trends (Winchester and Floyd, 1976; Winrhester and Max, 1984).

In the sheared samples of the pre-kinematic plutonic units in the study area, variable degrees of alteration are observed. The changes include partial replacement of plagioclase and hornblende by epidote and carbonate, biotite by chlorite and feldspar by sericite. However, chemical data from all of the plutonic units in this study show coherent behaviour. This coherence suggests that most of the samples have behaved as closed chemical systems.

\subsection{CLASSIFICATION}

The plutonic rocks vary considerably in modal mineralogy, particularly in the quartz content and proportion of plagioclase to K-feldspar. The rocks are classified according to Streckeisen (1976) using the modes of the 
plutonic units (Fig. 3.1a). Group (1) rocks fall in the range of diorite through quartz diorite to granodiorite; rocks of groups (2) and (3) fall in the 8:anite field. Because rocks from groups (1) and (2) are metamorphosed, chemical classification based on the proportions of normative minerals is preferable because it is somewhat difficult to establish primary modal mineralogy. Hietanen's (1963) and O'Connor's (1965) classifications in terms of the normative Ab-An-Or diagram show that samples of each pluton tend to cluster in distinct compositional fields (Figs. 3.1b and 3.2). In Group (1). the Bure pluton ranges from a mafic gabbro to diorite, data from the Haya pluton fall in the tonalite and monzotonalite fields, the Birbir data cluster predominantly in the granodiorite and quartz diorite fields, and the Goma data plot in the granite and trondhjemite fields. Data from groups (2) and (3) largely fall in the granite field, although a few fall in the quartz monzonite field.

Data from Group (1) rocks, plotted on an AFM $\left(\mathrm{Na}_{2} \mathrm{O}+\mathrm{K}_{2} \mathrm{O}\right.$ vs. FeO(Total) vs. $\mathrm{MgO}$ ) diagram, lie close to the calc-alkaline differentiation trend (Fig. 3.3). Low $\mathrm{FeO}_{(\mathrm{T})} / \mathrm{MgO}$ ratios (<1) from the Bure pluton suggest sub-alkaline characteristics (Mottana et al., 1968). The data from Group (1) rocks are plotted on the normative Qz-Ab-Or (Fig. 3.4a) and CaO-Na ${ }_{2} \mathrm{O}-\mathrm{K}_{2} \mathrm{O}$ plot (Fig. 3.4b), diagrams that have been widely used for chemical distinction between trondhjemites and calc-alkaline rocks (Barker and Arth, 1976; Barker, 1979). In the Haya pluton, the $\mathrm{Na}_{2} \mathrm{O} / \mathrm{K}_{2} \mathrm{O}$ ratios are mostly $>2$, values suggesting trondhjemitic affinity (Condie and Hunter, 1976). The trondhjemitic affinity of the Haya pluton is distinct from that shown by the rest of Group 


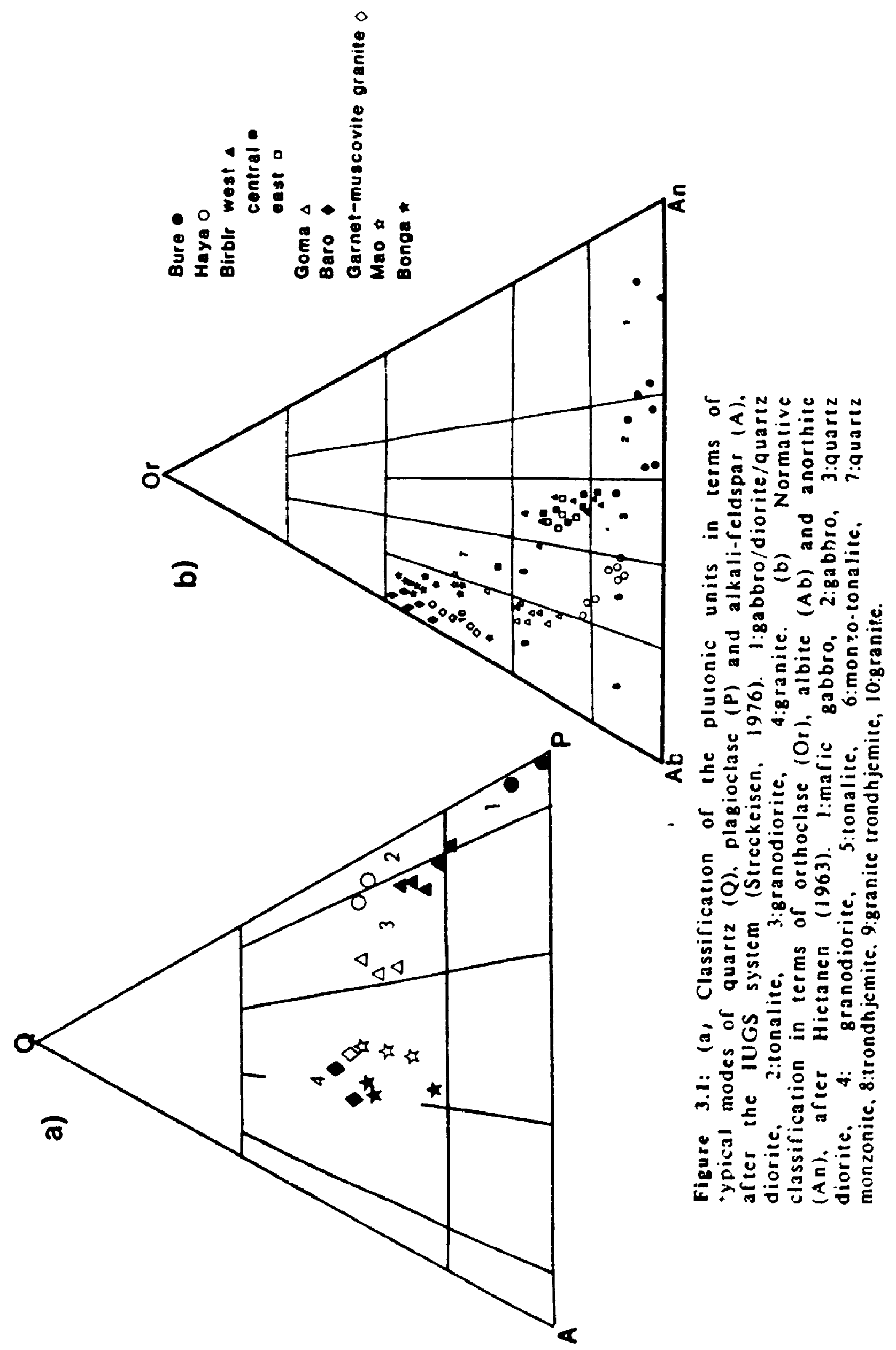




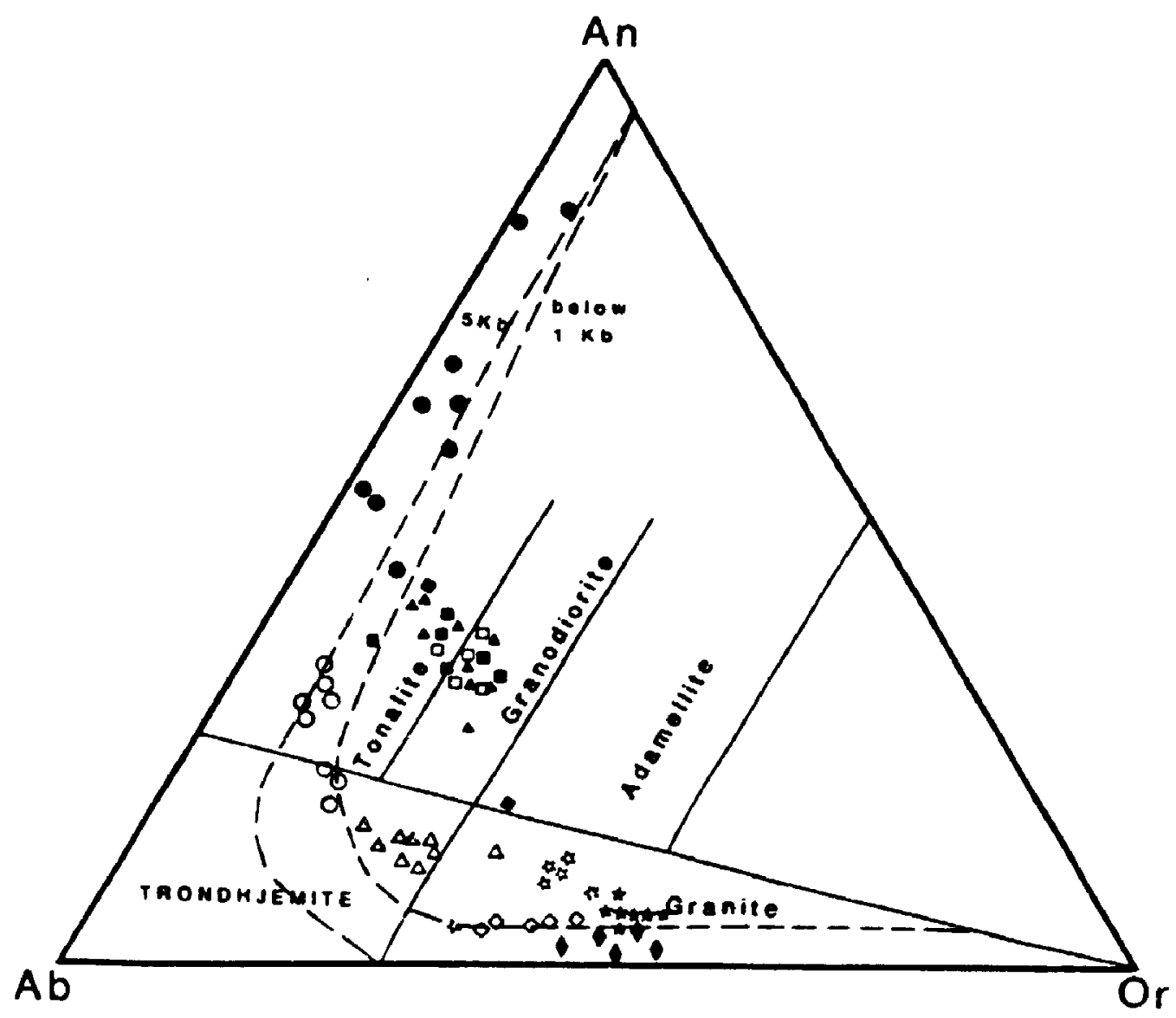

Figure 3.2: Normative proportions of $A b$, An and Or with classification boundaries of $\mathrm{O}^{\circ}$ Connor (1965); the dashed lines are feldspar solvi after Glikson and Sheraton (1972). Symbols same as in Fig. 3.1 (a). 


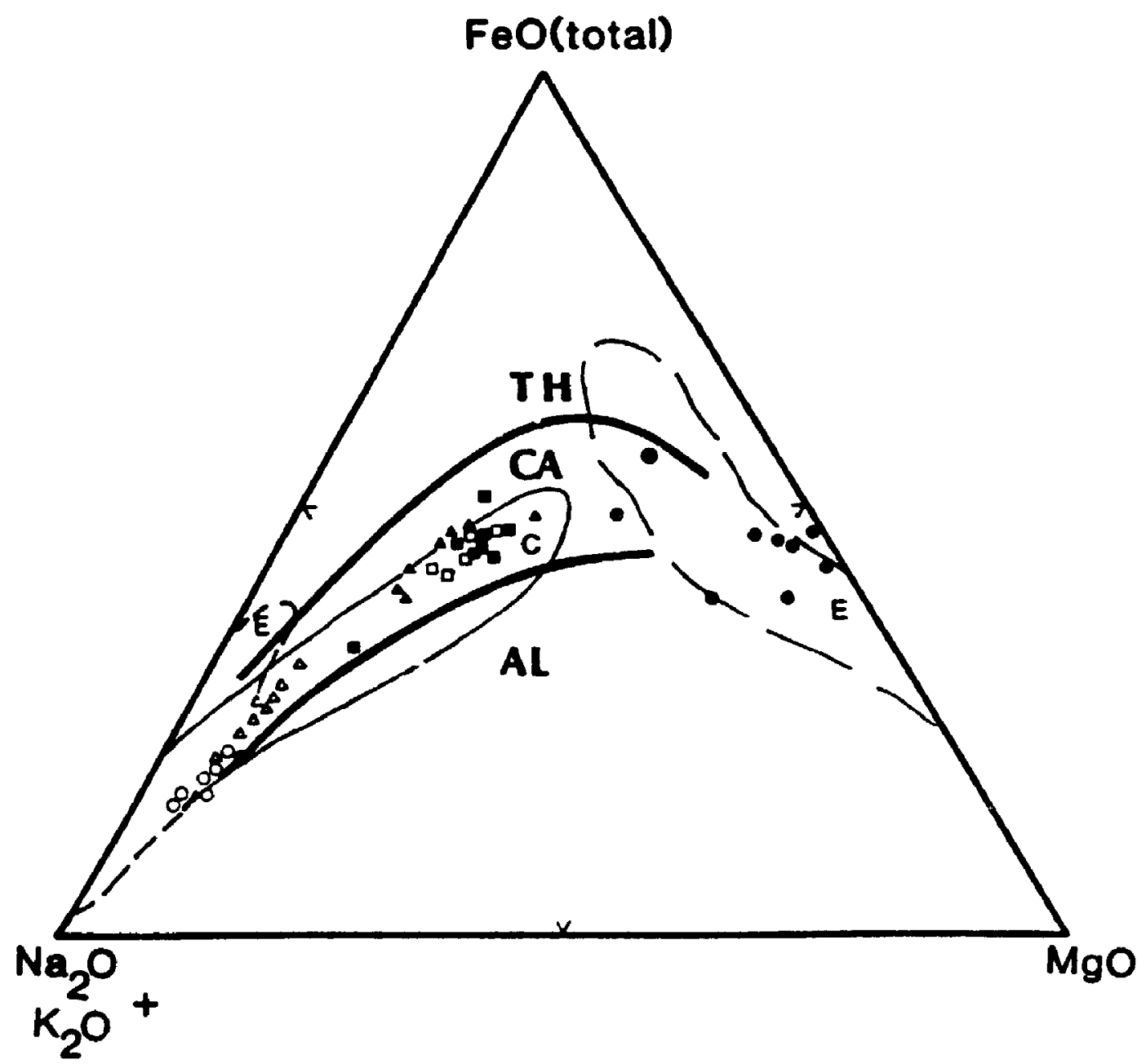

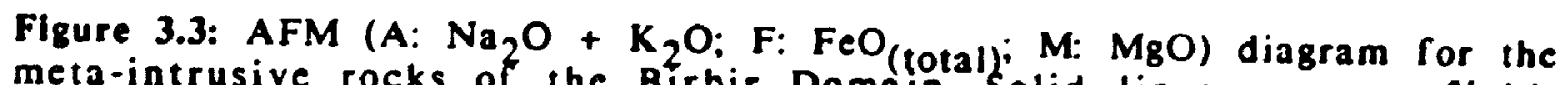
meta-intrusive rocks of the Birbir Domain. Solid lincs scparate rields of tholeiitic (TH), calc-alkaline (CA) and alkalic (AL) rocks. Also shown are fields for plutonic units from extensional (E) and compressional (C) tectonic settings (dashed lines) suggested by Petro et al. (1979). Symbols same as in Fig. 3.1 (a). 


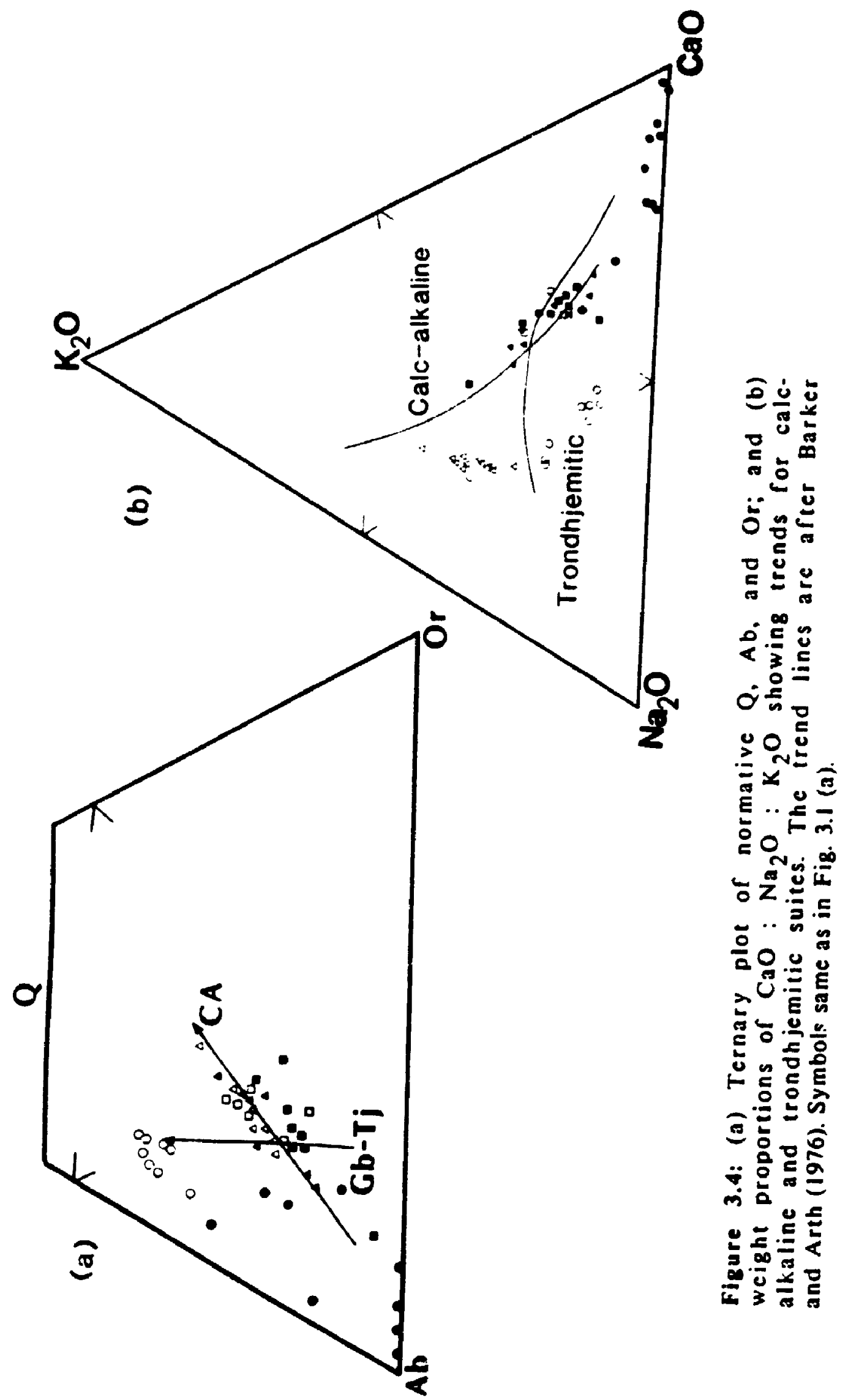


(1) plutonic units, which follow a strong calc-alkaline trend.

Both the Bure and Haya pluton, that lie close to one another spatially in the field. have generally low contents of large-ion-lithophile elements, particularly low $\mathrm{K}_{2} \mathrm{O}$ content. The Birbir intrusive complex and the Goma pluton have medium to high $\mathrm{K}_{2} \mathrm{O}$ content and follow a calc-alkaline trend (Figs. 3.3 and $3.4 a$ and 3.4b). Group (1) may thus be divided on the basis of major clement chemistry into two subgroups: a low-K sulte and calc-alkaline suite each of mafic and intermediate chemical composition.

In Shand's (1951) and Pitcher's (1983) alumina saturation classification, in which they used molecular proportions of $\mathrm{Al}_{2} \mathrm{O}_{3} /\left(\mathrm{CaO}+\mathrm{Na}_{2} \mathrm{O}+\mathrm{K}_{2} \mathrm{O}\right)(=$ ( $A / C N K)$, intrusive rocks are divided into peralkaline $(A<N K)$, metaluminous $(C N K>A>N K)$, subaluminous $(A=C N K)$, and peraluminous $(A>C N K)$. All rocks in groups (1) and (3) are metaluminous and hypersthene-normative, other than the Haya tonalites which appear to be marginally peraluminous (A/CNK cationic ratio of about 1.04 ) and contain normative corundum. Rocks of Group (2), however, are typically peraluminous. Garnet - muscovite granite (mgt) has an average cationic ratio for $A / C N K$ of 1.14 and normative corundum content of upto $2 \%$ whereas in the Baro leucogranites both $A / C N K$ and normative corundum contents are $<1$. However, both plutonic vaite of ist:p (2) contain garnet and/or muscovite, both aluminous minerals. These minerals coupled with the chemistry mean that rocks of Group (2) can be classified as peraluminous granites.

In terms of the alkalinity index, $(A I)=(A C N K / A C-N K)$, of Wright (1969), rocks of both groups (2) and (3) are alkaline $(A \mid>2.5)$, with moderate to high agpaitic ratios ((NK/A); Gerasimovski, 1956) ranging 
between 0.82 and 0.87 for Group (3) compared to about 0.5 for Group (2). The high alkali contents of Group (3) granites and the composition of the feldspars (predominantly microcline and albite, sec Chapter 2) allow them to be classified as alkall-feldspar granite.

Several different classification schemes for granitic rocks have been proposed in addition to the modal and normative mineral classifications. Chappell and White (1974) divided granitoid rocks into I- and S- types. The granites designated "I-type" were thought to represent melts derived from a metaluminous igneous rock source, and "S-type" from aluminousmetasedimentary source rocks. Ishihara (1977) classified granitic rocks in Japan into a magnetite and an ilmenite series that somewhat parallels Chappell and White's classification. Loiselle and Wones (1979) and Collins et al. (1981: suggested a group called A-type, characteristic of granites from anorogenic regions. The last are chemically distinct from the normal I- and S-type granites, and contain high $\mathrm{Na}_{2} \mathrm{O}, \mathrm{Nb}, \mathrm{Y}, \mathrm{Zr}, \mathrm{REE}$ and low $\mathrm{Ca} \mathrm{O}$. Pitcher (1981) introduced an M-type plutonic group, in addition to those above, which covered the most calc-alkaline plagiogranite.

For comparative purposes, trace element data of the various granite types of Chappell and White are shown in Table 3.5. Compositional data are compared in $\mathrm{K}_{2} \mathrm{O}-\mathrm{Na}_{2} \mathrm{O}$ space showing the I-, S- and A-type granites (Fig. 3.5). The cale-alkaline suite essentially falls in the I-type field whereas the data from the low-K suite fall outside any of the defined fields. Group (2) and (3) data scatter within the A-type boundary. It is surprising that analyses of Group (2) do not overlap the compositional field defined for S-type granites as they satisfy most of the chemical criteria for these 


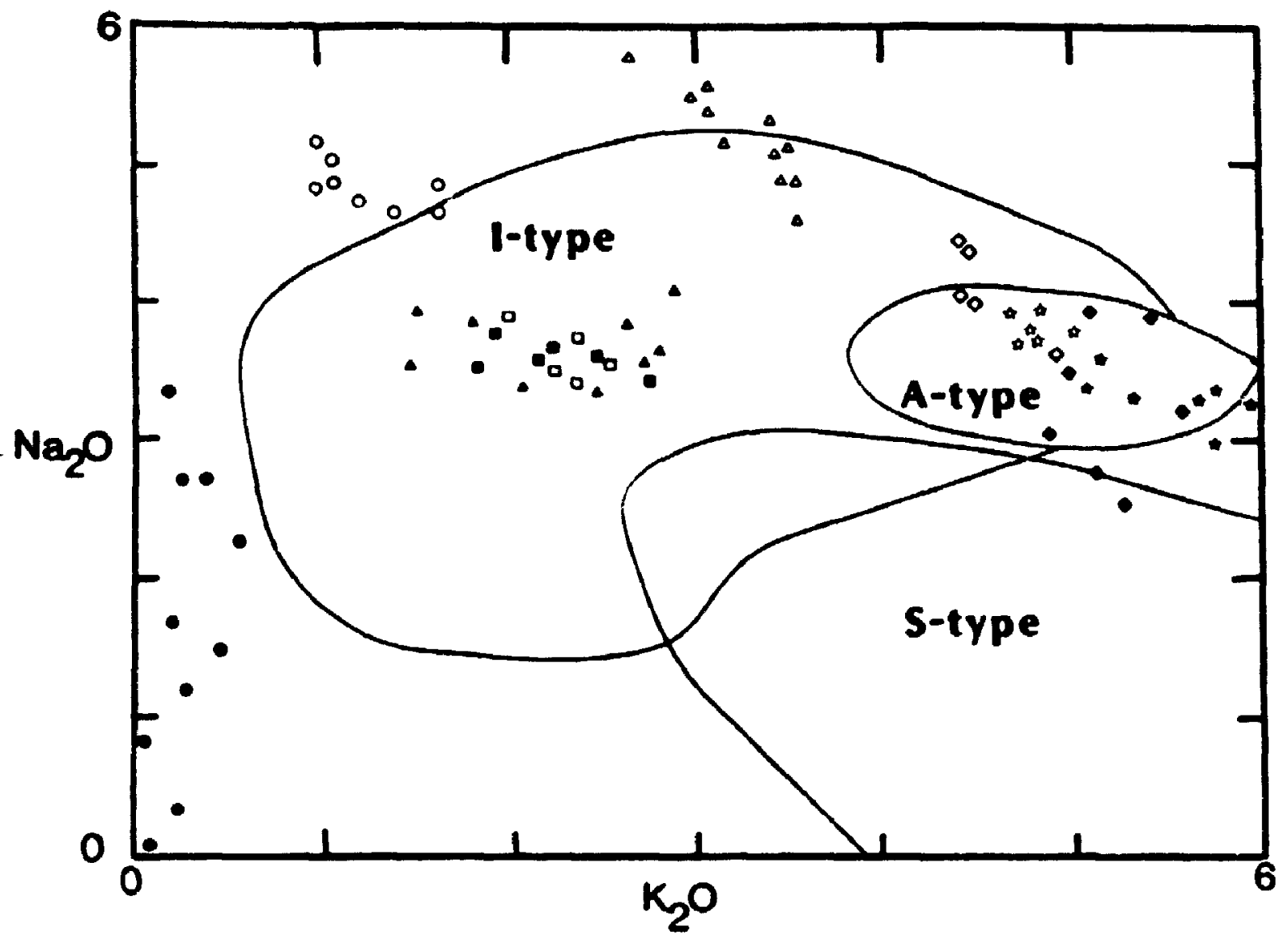

Figure 3.5: Plot of $\mathrm{Na}_{2} \mathrm{O}$ versus $\mathrm{K}_{2} \mathrm{O}$ with fields for 1-, $\mathrm{S}$ - and $\mathrm{A}$ type granites of White and Chappcll (1983) shown for comparison.

Symbols same as in Fig. 3.1 (a). 
granites. One potential explanation is that the Australian S-type granites owe their degree of alumina saturation to low $\mathrm{Na}_{2} \mathrm{O}$ and not to high $\mathrm{Al}_{2} \mathrm{O}_{3}$. Rocks of Group (2), however, owe their degree of alumina saturation, in part, to very low $\mathrm{CaO}$ whereas the abuadance of $\mathrm{Al}_{2} \mathrm{O}_{3}$ seems to be as high as the Australian rocks. The low $\mathrm{CaO}$ is characteristic of many sedimentary rocks because it is easily removed in weathering cycle.

The aluminous nature, the presence of two micas and the overall low incompatible element contents of the Haya tonalite of the low-K suite are consistent with M-type granite, whereas the hornblende-bearing, calcalkaline suite are similar to the I-type (Cordilleran) granitic rocks as described by Pitcher (1981). A summary of some lithologic and geochemical characteristics of the Birbir Domain plutons is given in Table 3.6.

\subsection{MAJOR- AND TRACE ELEMENT CHEMISTRY}

3.6.1 Pre- to sya-kinematic mafic and intermediate intrusive complex: Group (1)

The spatially associated Bure gabbro and Haya tonalite of Group (1) have extremely low $\mathrm{K}_{2} \mathrm{O}$ content. The tonalite has distinctly high $\mathrm{Na}_{2} \mathrm{O}$ and low $\mathrm{CaO}$ in contrast to LeMaitre's (1976) average tonalite and other rocks of comparable $\mathrm{SiO}_{2}$ content (Tables 3.1 and 3.2). Both the Bure and Haya plutons have low overall large-ion lithophile element abundance suggesting a common origin; they may be designated as a low-K suite, with bimodal $\mathrm{SiO}_{2}$ values of 46-55 and 69-73 wt.\%. $\mathrm{MgO}_{1} \mathrm{FeO}(\mathrm{T}), \mathrm{CaO}$, and $\mathrm{TiO}_{2}$ decrease as $\mathrm{SiO}_{2}$ increases. $\mathrm{Al}_{2} \mathrm{O}_{3}$ has mean values of $14.0 \mathrm{wt} . \%$ in the mafic and $15.93 \mathrm{wt} . \%$ in the felsic rocks. 
Table 3.6: Summary of the distinctive petrologic and geochemical characteristics of the plutonic units within the Birbir Domain.

$$
\begin{aligned}
& \text { Group (1) : Pre- and syn-klnematle } \\
& \text { low-K suite } \\
& \text { calc-alkaline suite }
\end{aligned}
$$

$\begin{array}{ll}\text { Lithology } & \text { tonalite subordinate } \\ & 10 \text { composite gabbro } \\ \text { and dioritc: (gb,di. } \\ 11,18 \text { ) }\end{array}$

Mludal hornblende in gb

mineralogs and Iwo-mica in tt

$\mathrm{SiO}_{2}$ Shand's
d/CNk
C.I.P.W.
norms

AFM,

Qz-AU-O) ircind

$\mathrm{K}_{2} \mathrm{O}$ -

$\mathrm{SiO}_{2}$

trend

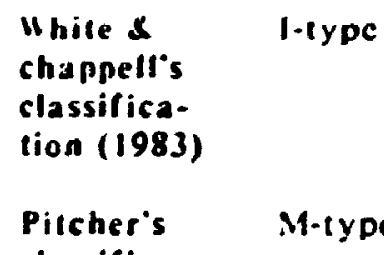

\section{Pilcher's}

I-1ype classifica. tiun (1983)

Bimodal: 46- 55 and $69-73$ wt.\%

I OA (PA) for 11

corundum-normalive

tonalites; and

hypersthene in gabbro

trondhjemitic for tt and subalkaline $g b$

Occanic is' 1 re of Fijian tyr.

quartz dioriec dominane but broad compositional spectrum: diorite to granodioritc: major association with gabbro; gb,di,da,(8.1t)

hornblende and biotitc

Unimodal: 55.68 wt.\%

$0.96(\mathrm{MA})$

hypersthene-normative

calc-alkaline

alkaline

Peruvian/Andinotype marginal continental arc typc Group (3): Late- 10
post- Kinematic

alkali-feldspar sranitc: (8m,18.81)

hornblende and biotite

Unimodal: 68-79 w1.\%

0.99 (MA)

hypersthene. normative

anorogenic/ intraplate

I-typc

A-typc

I-type (cordilleran)

A-type

Lithulog $\because$ gb. gabbro; di, dioritc; dq. quartz-dioritc; tt, tonalitc; tg. gianodiorite; $8 \mathrm{~m}$, monzogranitc; qm, quartz monzonitc; gt, granite.

ACNK: $\mathrm{Al}_{2} \mathrm{O}_{3}, \mathrm{CaO}, \mathrm{Na}_{2} \mathrm{O}, \mathrm{K}_{2} \mathrm{O}$; PA: pcraluminous; MA: mclaluminous 

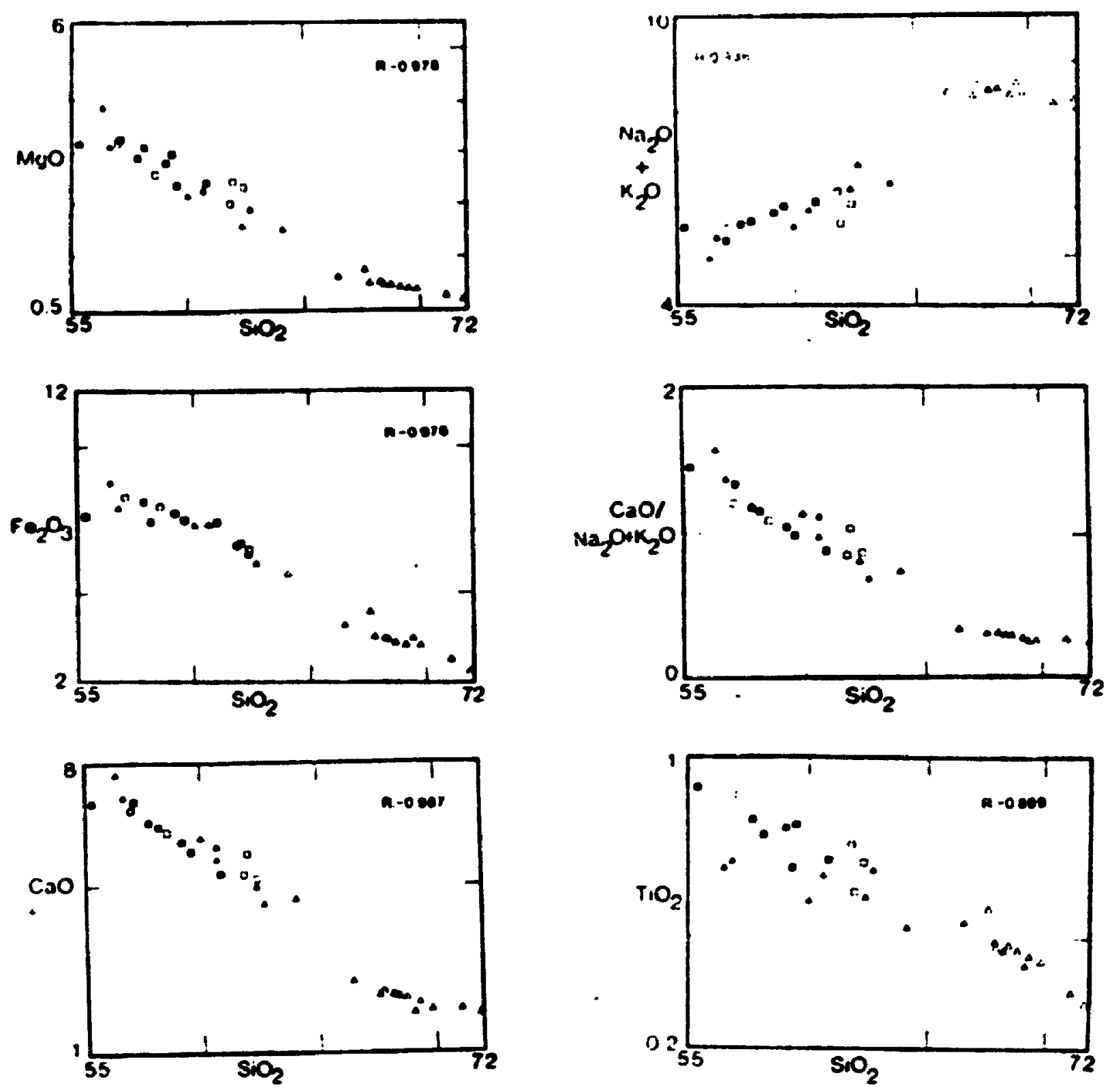

Figure 3.6: Variation diagrams for the unimodal - calc alkaline suite of Group ( 1 ) plutonic units. $(R=$ correlation coefricient)

Symbols same as in Fig.3.1 (a). 

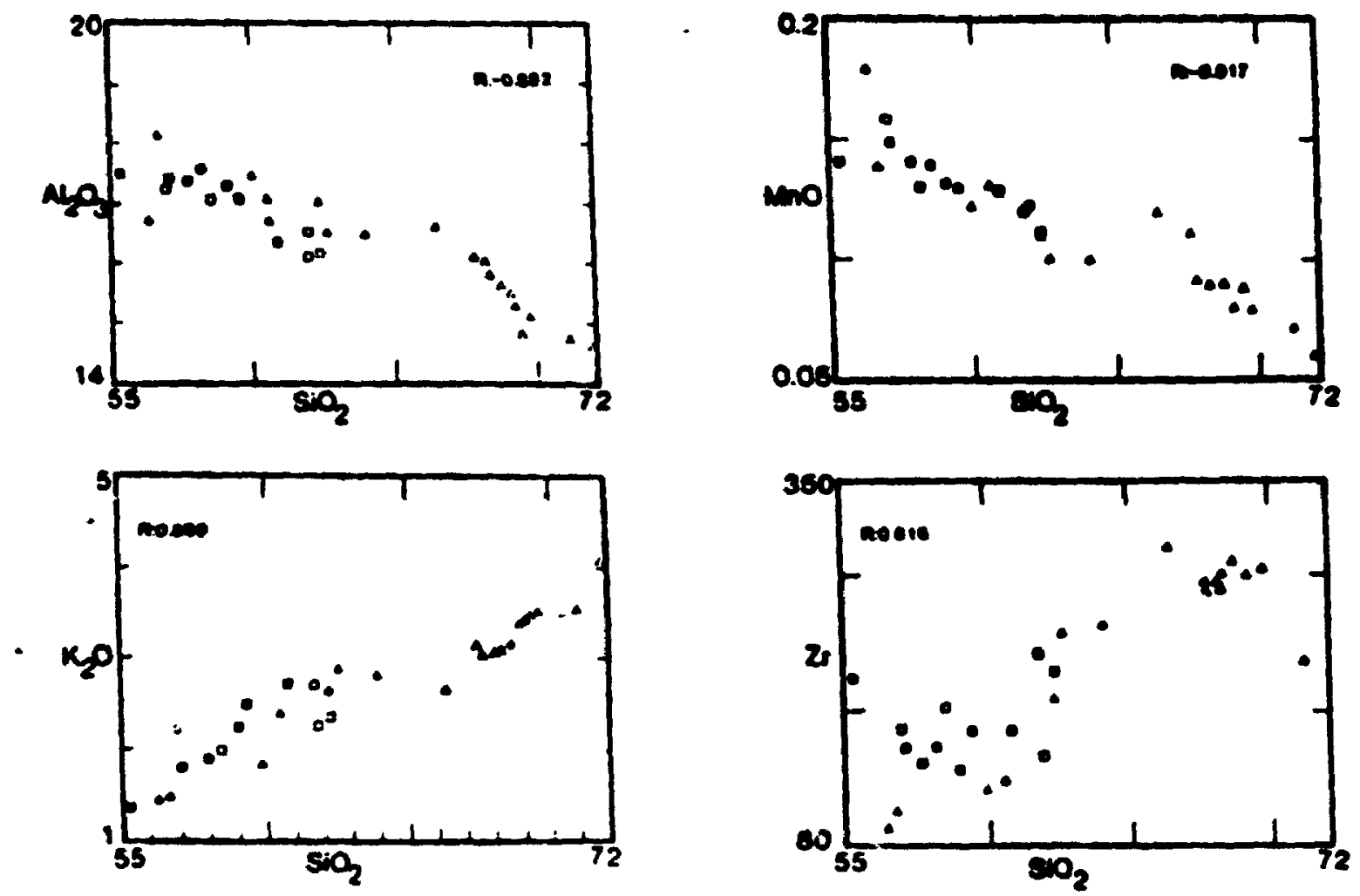

Figure 3.6 (continued): 

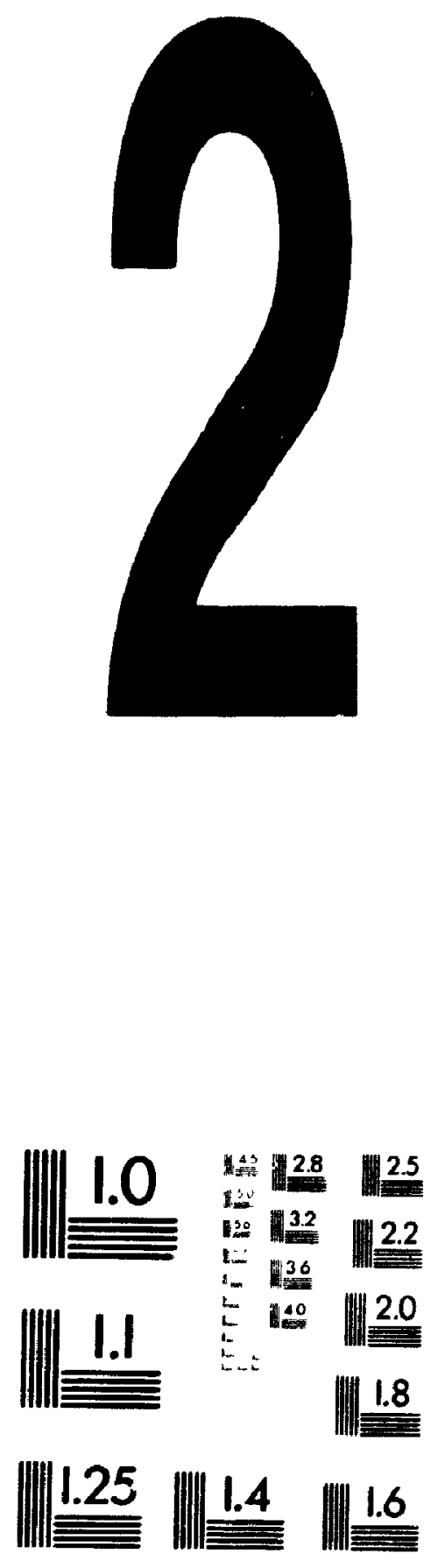

222 
The calc-alkaline suite, comprising the Birbir quartz diorite and Goma granodiorite, covers a broad range of $\mathrm{SiO}_{2}$ values from 55.72 wt.\%. There is a linear variation of $\mathrm{SiO}_{2}$ with some majo: oxides (Fig. 3.6); $\mathrm{Al}_{2} \mathrm{O}_{3}, \mathrm{MgO}_{\text {. }}$ $\mathrm{FeO}_{(\mathrm{T})}, \mathrm{TiO}_{2}, \mathrm{CaO}, \mathrm{MnO}$ and $\mathrm{P}_{2} \mathrm{O}_{5}$ decrease, and alkalis increase as $\mathrm{SiO}_{2}$ increases. The Goma granodiorite shows a slight differences from the Birbir quartz diorite in its content of some oxides such as $\mathrm{Na}_{2} \mathrm{O}$. Variation diagrams (Fig. 3.6) with significant correlation coefficients $(>0.9)$ suggest magmatic differentiation of the suite from a single parent magma. Overall, the major element chemistry follows a calc-alkaline differentiation trend (Fig. 3.4). Trace element distributions differ little between the Goma and Birbir plutons (Table 3.5). The overall mean values of the ma jor elements for the Birbir intrusive complex and Goma pluton are similar to those given by LeMaitre for diorite and granodiorite respectively (Table 3.2).

There is a general decrease in the concentrations of $\mathrm{Cr}, \mathrm{Ni}, \mathrm{Zr}, \mathrm{Zn}, \mathrm{Y}$ and $\mathrm{V}$, and an increase of $\mathrm{Ba}, \mathrm{Sr}, \mathrm{Nb}$ and $\mathrm{Rb}$ from mafic to felsic compositions of the low-K suite. The abundances of $R b, N b$ and $Y$ are not far removed from Wood's (1979) estimate of primordial mantie values for these elements of $15,0.6$ and 5 ppm respectively.

Barium, $\mathrm{Sr}, \mathrm{Zr}, \mathrm{V}$ and $\mathrm{Y}$ contents broadly decrease whereas $\mathrm{Rb}$ increases with increasing $\mathrm{SiO}_{2}$ in the calc-alkaline suite. Strontium decreases with decreasing $\mathrm{CaO}$ and $\mathrm{Ba}$, and $\mathrm{Rb}$ tends to closely follow $\mathrm{K}_{2} \mathrm{O}$. Chromium and $\mathrm{Ni}$ follow the $\mathrm{MgO}$ concentrations. Over the wide silica range shown by Group (1) rocks there is a general decrease of $\mathrm{CaO}$ and $\mathrm{Sr}$ and increase in $\mathrm{K}_{2} \mathrm{O}, \mathrm{Ba}$ and 
$R b$. The former suggests significant plagioclase fractionation, while the latter may be due mainly to biotite and to a lesser extent K-feldspar fractionation. The distinctive chemical difference between the calc-alkaline suite and the felsic rocks of the low-K suite is the geceral enrichment in the calc-alkaline rocks of large-ion-lithophile elements such as $\mathbf{R b}, \mathrm{Ba}, \mathrm{Th}$, $\mathrm{U}$, the high $\mathrm{Rb} / \mathrm{Sr}$ and $\mathrm{Ba} / \mathrm{Sr}$ and low $\mathrm{K} / \mathrm{Rb}, \mathrm{Ba} / \mathrm{Rb}, \mathrm{Th} / \mathrm{U}$ and $\mathrm{Zr} / \mathrm{Nb}$ abundance ratios.

\subsubsection{Peraluminous and alkall-feldspar granites: Groups (2) \& (3)}

Rocks of Group (2) differ markedly from those of Group (3). They show strong peraluminosity and moderate agpaitic ratio ( -0.5$)$. Group (3) plutons have distinctive chemical characteristics that include high $\mathrm{K}_{2} \mathrm{O}, \mathrm{K}_{2} \mathrm{O} / \mathrm{Na}_{2} \mathrm{O}$, $\mathrm{Fe}_{2} \mathrm{O}_{3}$, low $\mathrm{CaO}, \mathrm{M}_{8} \mathrm{O}$, and $\mathrm{Al}_{2} \mathrm{O}_{3}$; alkalinity indices in excess of 1.5 , high agpaitic ratios upto 0.87 . They also oceur as discordant intrusive bodies.

The trace element patterns of groups (2) and (3) shown in Table 3.5 are marked by high abundances of Rb, Sr, Ba and Th. Barium and Sr tend to decrease irregularly while $\mathrm{Rb}$ increases with increasing silica and tends to follow $\mathrm{K}_{2} \mathrm{O}$. On the basis of high differentiation indices (normative $\mathrm{Qz}+$ Or

$+\mathrm{Ab}$ ) that exceed 90 and $\mathrm{Rb}, \mathrm{Sr}$ and $\mathrm{Ba}$ abundances, the Mao and Bonga plutons are relatively differentiated granites. In general terms, concentrations of many large-ion-lithophile elements, including $\mathrm{Nb}, \mathrm{Th}, \mathrm{U}, \mathrm{Zr}, \mathrm{Y}, \mathrm{Ta}$ and $\mathrm{Hr}$, are enhanced in Groups (2) and (3).

\subsection{REE DISTRIBUTION}

The REE data, given in Appendix 2, Table A2.2, and summarized in Table 
3.7, characterize each of the plutonic units despite the limited number of analyses. The data are plotted on chondrite-normalized (cn) diagrams in Figures 3.7 a, b, and c. The patterns shown on these diagrams are different from one another and closely correspond to the groupings of the plutonic units based on geological and major element chemical differences. REE patterns of six samples from Group (1) plutons are shown in Figure 3.7a. The patterns depict slight enrichment in the light rare earth elements (LREE) $\mathrm{La}_{\mathrm{Sm}} \mathrm{m}_{(\mathrm{cn})}$ ratios between 2.5 to 4.2 and flat to poorly fractionated heavy rare earth elements (HREE).

The low-K suite (Bure and Haya plutons, Fig. 3.7a) has a relatively low absolute REE abundances (40-75 ppm), flat to poorly fractionated HREE patterns and no Eu anomaly (Eu/Sm: 0.31-0.32). The Haya pluton shows a large LREE/HREE ratio (La/Lu(cn) of about 10). Four analyses from different members of the calc-alkaline suite have extremely similar distributions and abundances, all have the same fractionated LREE patterns. The La/Lu(cn) ratio lies between 5.1 and 7.5 , and $\mathrm{Eu} / \mathrm{Sm}$ of 0.23 to 0.27 (i.e. little or no Eu anomaly) and REE contents are low to moderate (99-121 ppm). The Haya pluton of the low-K suite is more LREE enriched than the calc-alkaline suite. Apart from this, there appears to be a gross similarity in patterns between the low-K and calc-alkaline suites that reflects little or no difference in the nature of the magma and source material.

The absence of any Eu anomaly in rocks of Group (1) can be explained in terms of the redox conditions of the melt. In oxidizing conditions $E_{u}+3$ tends to substitute for $\mathrm{Ca}$ in the large cation site of plagioclase and thus europium is removed during fractional crystallization. The oxygen fugacity 
Table 3.7: Summary of REE distribution in terms of LREE enrichment, LREE/HREE ratio, Eu-anomaly and absolute abundances.

1 represent the compositional ranges for calc-alkaline rocks of island-arc and continental subduction zones (after Cullers and Graf, 1986) cn: chondrite normalized.

\begin{tabular}{|c|c|c|c|c|}
\hline Sample \# & $\mathrm{La} / \mathrm{Sm}(\mathrm{cn})$ & La / Lu (cn) & Eu/Sm & ₹REE $(\mathrm{ppm})$ \\
\hline \multicolumn{5}{|l|}{ Group 1} \\
\hline $\begin{array}{l}\text { 4D (Burc) } \\
\text { IA (Haya) }\end{array}$ & $\begin{array}{l}4.12 \\
4.18\end{array}$ & $\begin{array}{r}5.3 \\
10.1\end{array}$ & $\begin{array}{l}0.31 \\
0.32\end{array}$ & $\begin{array}{l}75.01 \\
40.96\end{array}$ \\
\hline $\begin{array}{l}111 \text { (Birbir) } \\
1 H \text { (Birbir) } \\
3 G \text { (Birbir) }\end{array}$ & $\begin{array}{l}2.96 \\
2.68 \\
2.52\end{array}$ & $\begin{array}{l}5.3 \\
7.5 \\
5.1\end{array}$ & $\begin{array}{l}0.23 \\
0.27 \\
0.26\end{array}$ & $\begin{array}{r}121.17 \\
115.45 \\
99.76\end{array}$ \\
\hline 6J (Goma) & 3.42 & 5.9 & 0.26 & 114.37 \\
\hline \multicolumn{5}{|l|}{ Group 2} \\
\hline $\begin{array}{l}8 F(\text { Baro }) \\
4 M\end{array}$ & $\begin{array}{l}3.76 \\
2.50\end{array}$ & $\begin{array}{r}11.1 \\
2.3\end{array}$ & $\begin{array}{l}0.09 \\
0.09\end{array}$ & $\begin{array}{r}462.86 \\
74.43\end{array}$ \\
\hline \multicolumn{5}{|l|}{ Group 3} \\
\hline $\begin{array}{l}90 \text { (Mao) } \\
8 \mathrm{~K} \text { (Bonga) } \\
8 \mathrm{~L} \text { (Bonga) }\end{array}$ & $\begin{array}{l}3.79 \\
2.82 \\
3.51\end{array}$ & $\begin{array}{l}7.8 \\
7.6 \\
8.8\end{array}$ & $\begin{array}{l}0.14 \\
0.07 \\
0.14\end{array}$ & $\begin{array}{l}308.28 \\
261.19 \\
484.62\end{array}$ \\
\hline * 1 & & $0.31-19.3$ & $0.23-0.38$ & $12-273$ \\
\hline
\end{tabular}




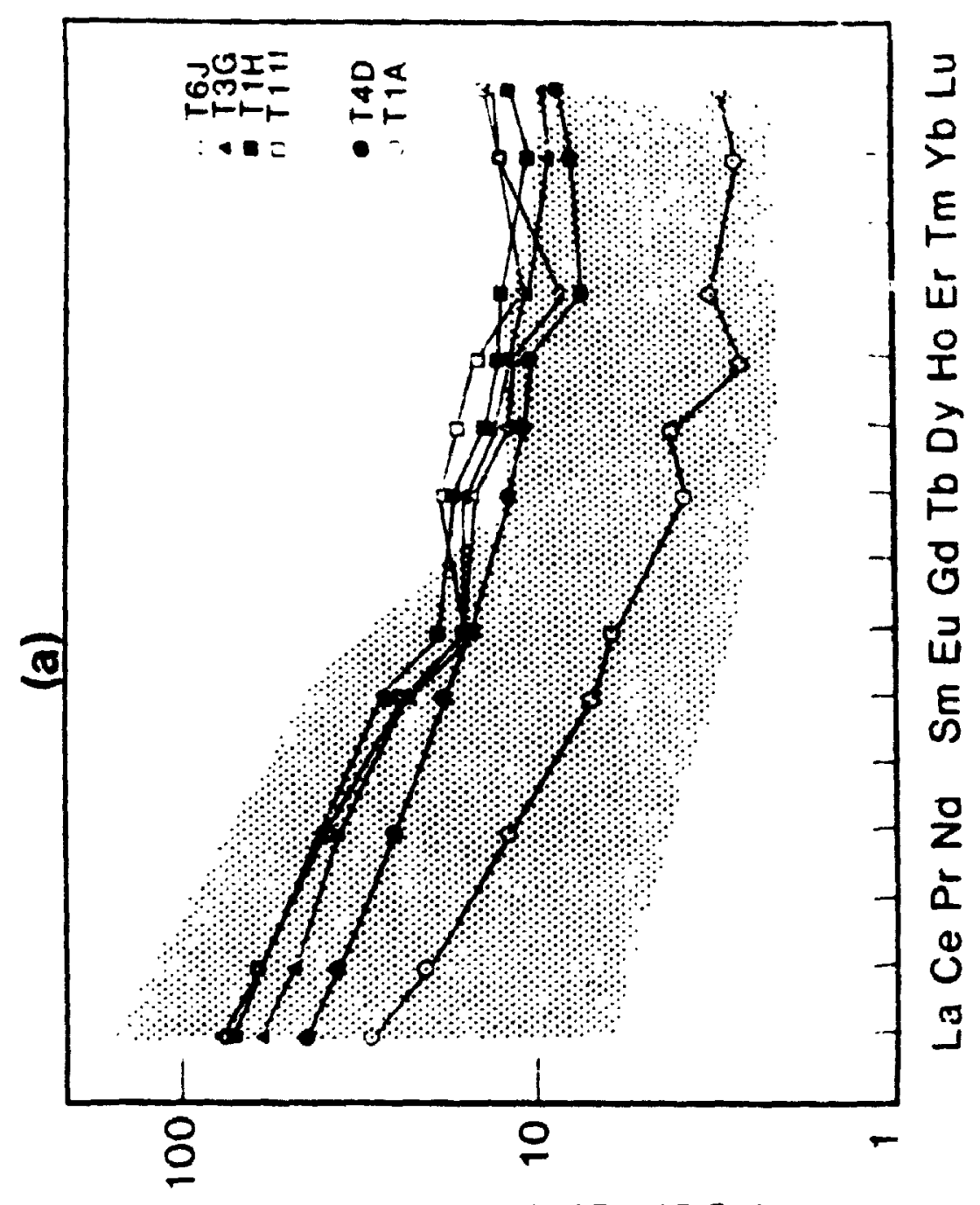

\section{ЭLIYONOHO/Y्रOOY}

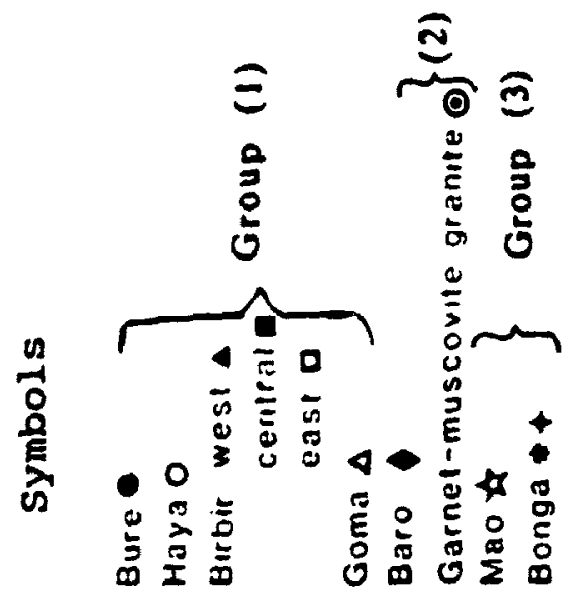

$\div$

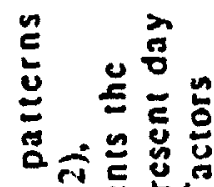

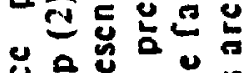

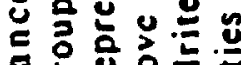

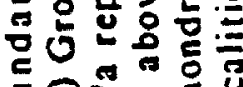

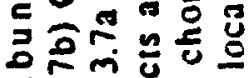
ल

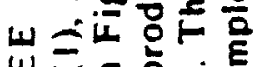

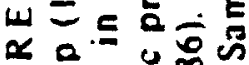
$\alpha$ 응드응

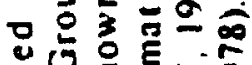

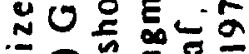
元药

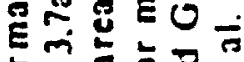

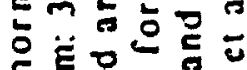
옹ㅎㅁㅇㅢ

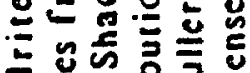

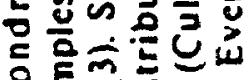

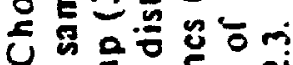
노은

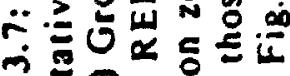
홍ํㅗ

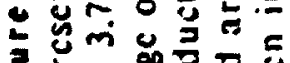

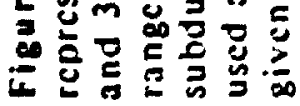



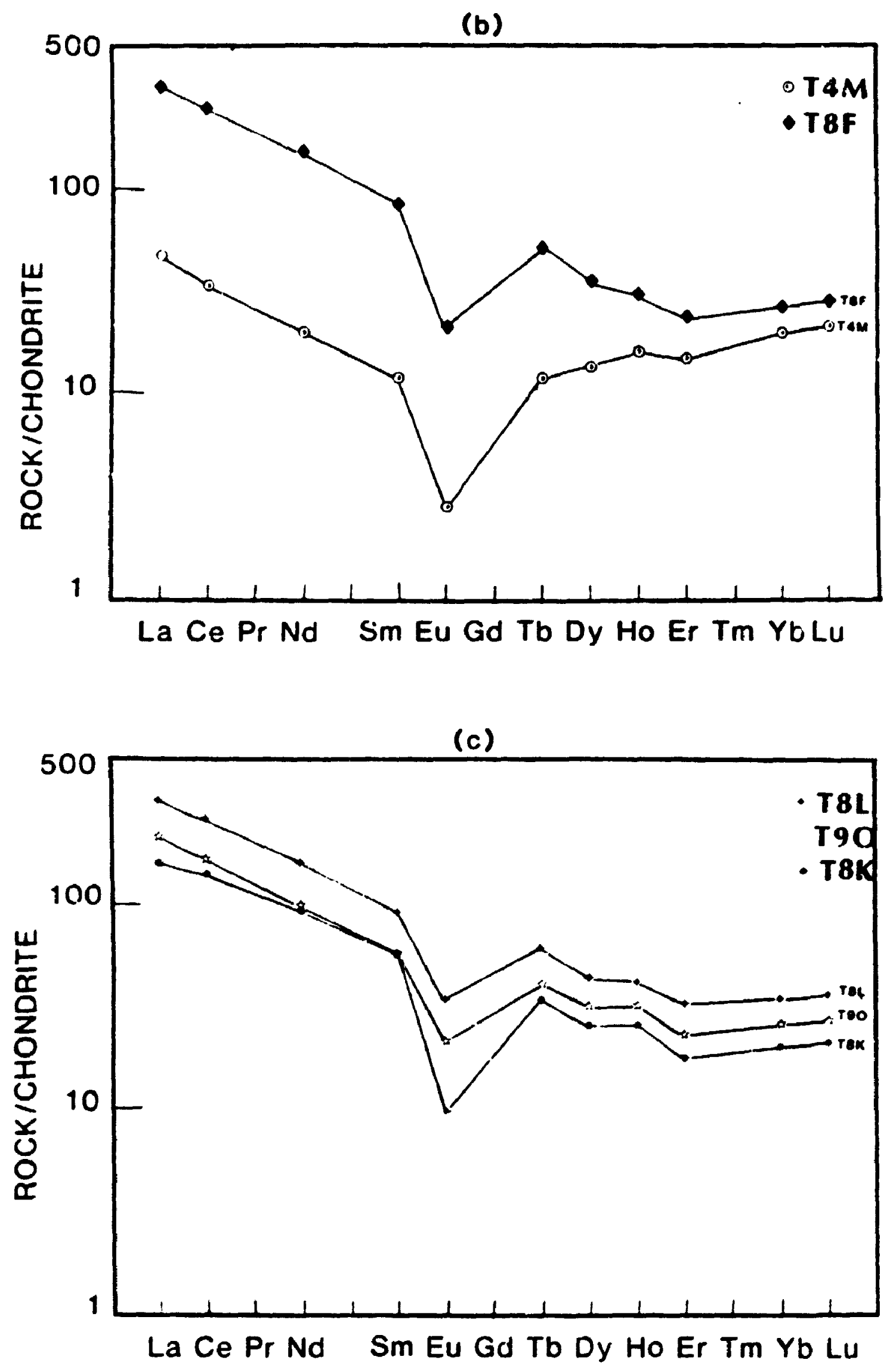

Figure 3.7 (conlinued): 
during crystallization of Group (1) magmas appear to be low, a condition that is consistent with the little or no modal magnetite and ilmenite. The Group (1) REE patterns and abundances are similar to those shown by calcalkaline rocks of island arc and continental subduction zones (Fig. 3.7a).

The REE data from rocks of Groups (2) and (3) differ from those shown by Group (1) rocks. Group (2) and (3) samples show strong negative Eu anomalies (Eu/Sm= 0.07-0.14) and most are more enriched in the LREE than Group (1) rocks. Rocks of Group (3) in comparison to those of Group (1) (Fig. 3.7c) show a significant enrichment of LREE over HREE (La/Yb (cn) $=7.6$ 8.8), and higher REE abundances (EREE: 261 -485 ppm). The garnet - muscovite granite has lower REE abundances ( $74 \mathrm{ppm}$ ), and a flat to concave-upward pattern similar to patterns typically observed in peraluminous granites (Muecke and Clarke, 1981). Data from the Baro granite sheet, on the other hand, have high REE abundances (460 ppm) and are more LREE enriched $\left(L a / L u_{(e n)}=11.1\right)$. The mineralogical differences between the two, particularly the more abundant biotite, zircon and apatite in the Baro leucogranite, could account for the difference in the REE abundances.

\subsection{TECTONIC IMPLICATIONS}

Trace element abundances and ratios in granitoid rocks (Pearce et al. 1984; Harris et al. 1986) from known tectonic settings have been used to discriminate empirically the geologic setting of granitic rocks. The data define four main groups that reflect (i) ocean ridge (ORG), (ii) volcanic arc (VAG), (iii) within plate (WPG) and (iv) collision granites (COLG). Inter-element plots were used for the granitoid rocks of the study area. 
These include $R b$ vs $(Y+N b), N b$ vs $Y, R b$ vs $(Y b+T a)$ and $T a$ vs $Y b$ diagrams (Figs. 3.8 a-d, 3.10). In all of these diagrams the data from the Group (1) rocks suggest that these bodies are the product of magmatic arc activity (VAG), whereas Groups (2) and (3) reflect intra-plate activity (WPG).

Petro et al. (1979) used major elements to recognize granitoid rocks from compressional and extensional plate margins. The diagnostic characteristics of rocks from extensional environments are: alumina undersaturation, high $\mathrm{FeO}$ and low $\mathrm{MgO}$ and $\mathrm{CaO}$, whereas rocks from compressional environments show alumina oversaturation, low FeO, and high $\mathrm{MgO}_{\mathrm{g}}$ and $\mathrm{CaO}$. Major element distribution fields defined on an AFM diagram (Fig. 3.3) suggest an extensional environment for the low-K suite and a compressional setting for the calc-alkaline suite. The low-K suite, however, has $\mathrm{Nb}, \mathrm{Zr}, \mathrm{Rb}, \mathrm{TiO}_{2}$ and $\mathrm{K}_{2} \mathrm{O}$ more akin to the basaltic members of the island arc volcanic series of Gill (1981) than to the compositions of intrusives formed under conditions of spreading or back-are rifting. The chemical characteristics of Group (1) rocks, especially the calc-alkaline suite, appear to be typical of granites from orogenic zones. The calc-alkaline suite is hornblende-bearing and exhibits most of the chemical characteristics normally associated with pre-collision calc-alkaline intrusions of a magmatic arc (VAG).

Magmatic arc granites can vary in setting from oceanic to continental. In Fig. 3.9 data from rocks of Group (1) are compared with Phanerozoic plutonic rocks in an attempt to evaluate their tectonic settings. The data from the calc-alkaline suite overlap the data from the Peruvian coastal batholith. Of the low-K suite, the Haya pluton shows similarities with the 


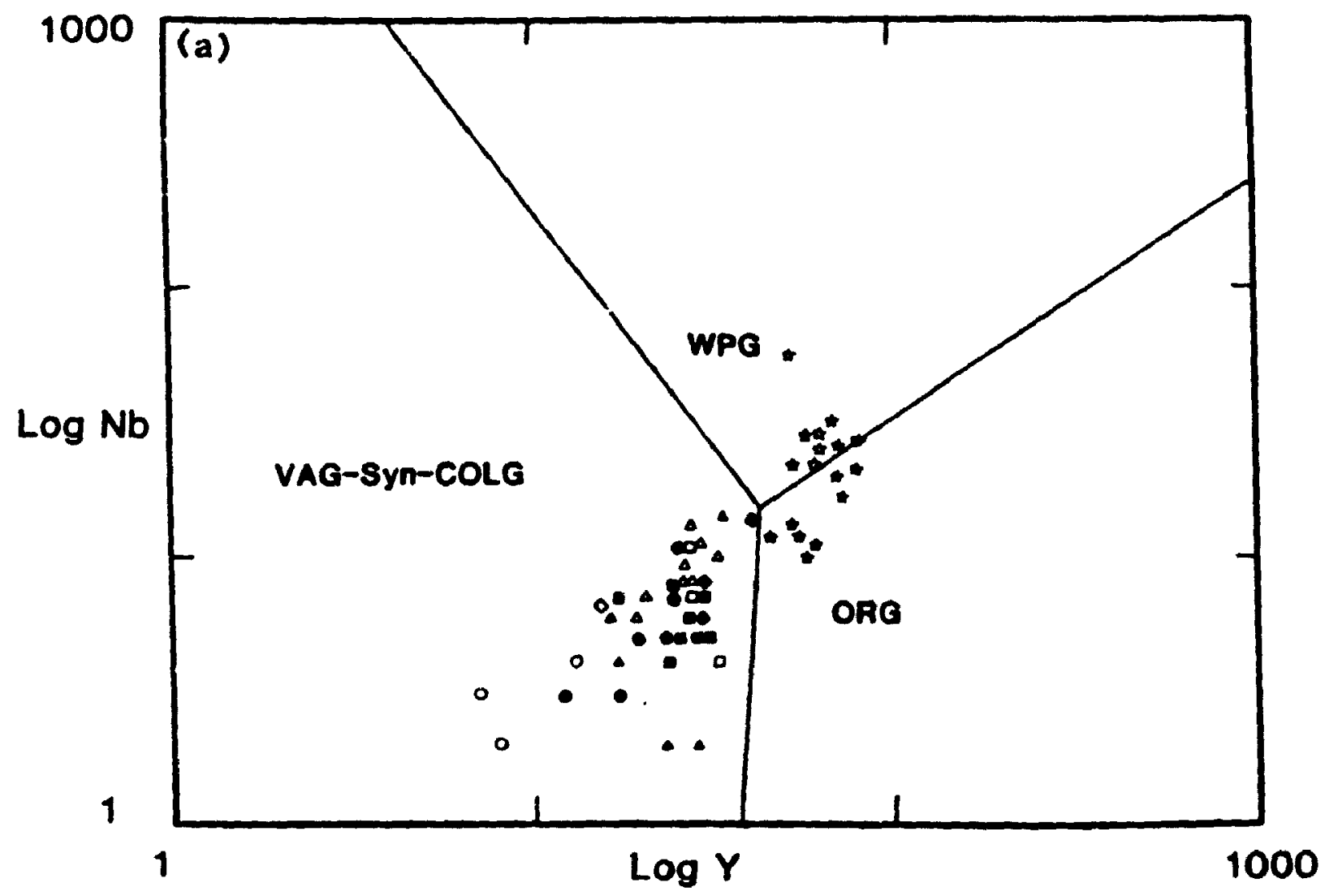

Figure 3.8: Trace elements define three fields. These are ocean ridgc granites (ORG), within plate granites (WPG) and collision granites (syn-COLG) plus volcanic arc granites (VAG) (after Prarce et al., 1984; Harris et al., 1986); (a) Nb-Y (b) Rb-(Y+Nb) (c) Rb $(\mathrm{Yb}+\mathrm{Ta})$ (d) $\mathrm{Ta}-\mathrm{Yb}$. Symbols same as in Fig. 3.1 (a).

Figure 3.8 (continued): 

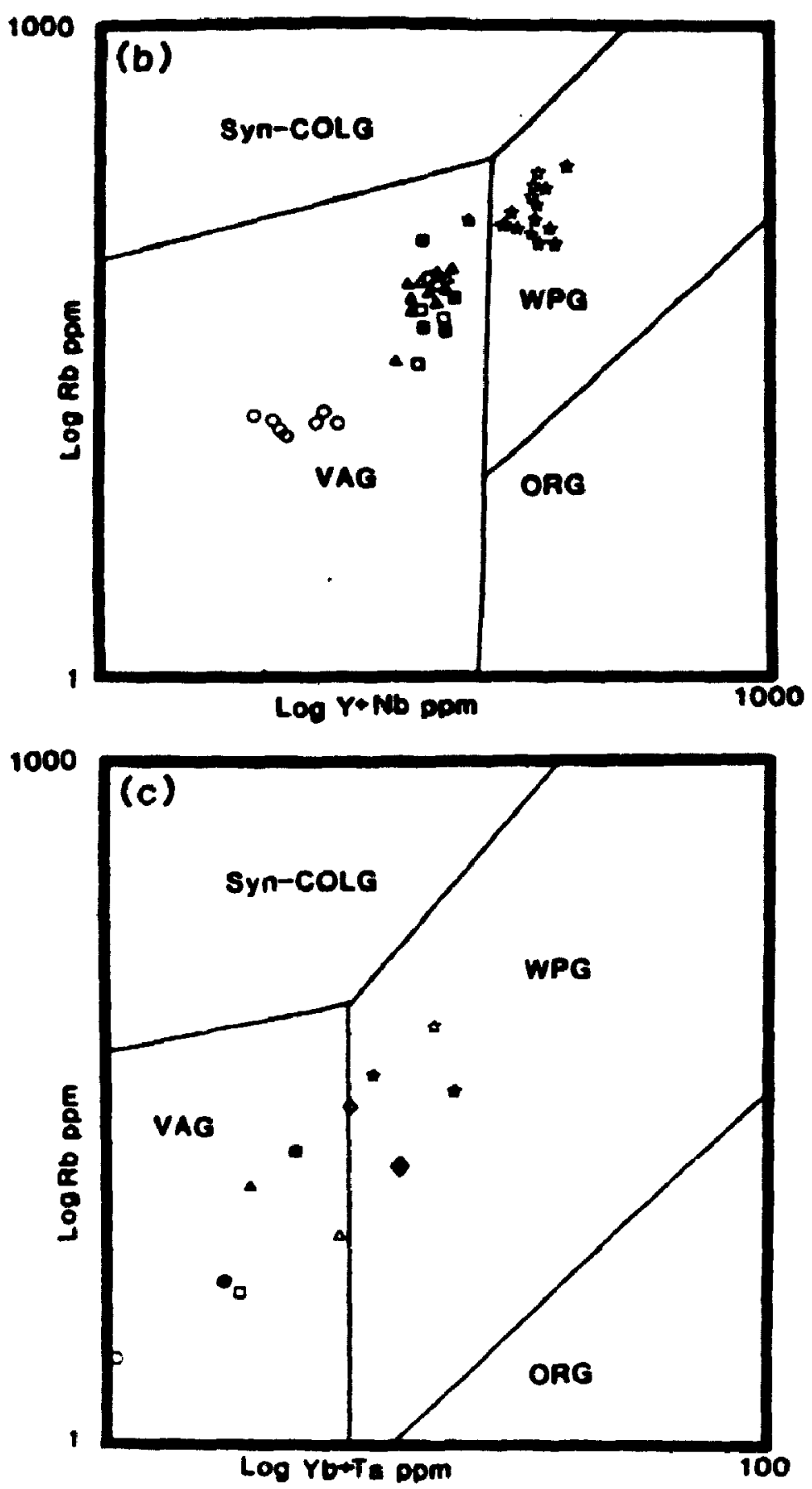


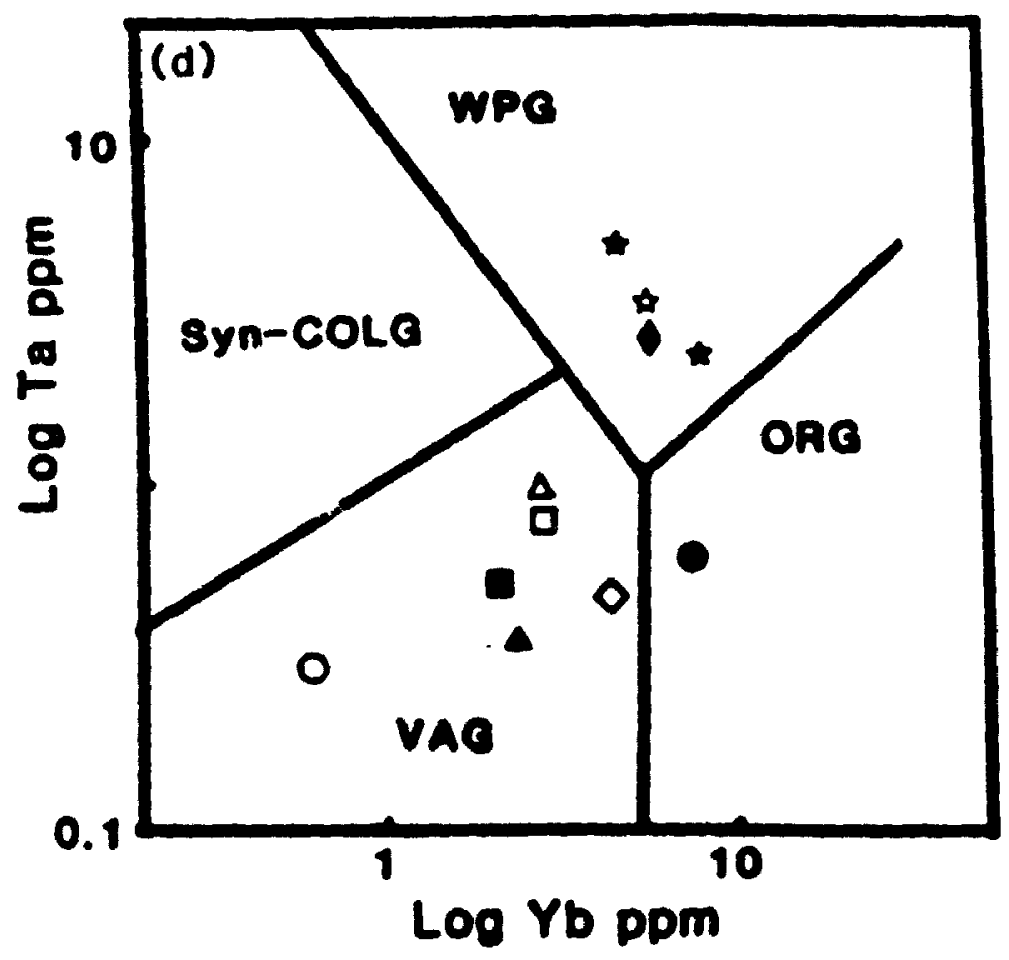




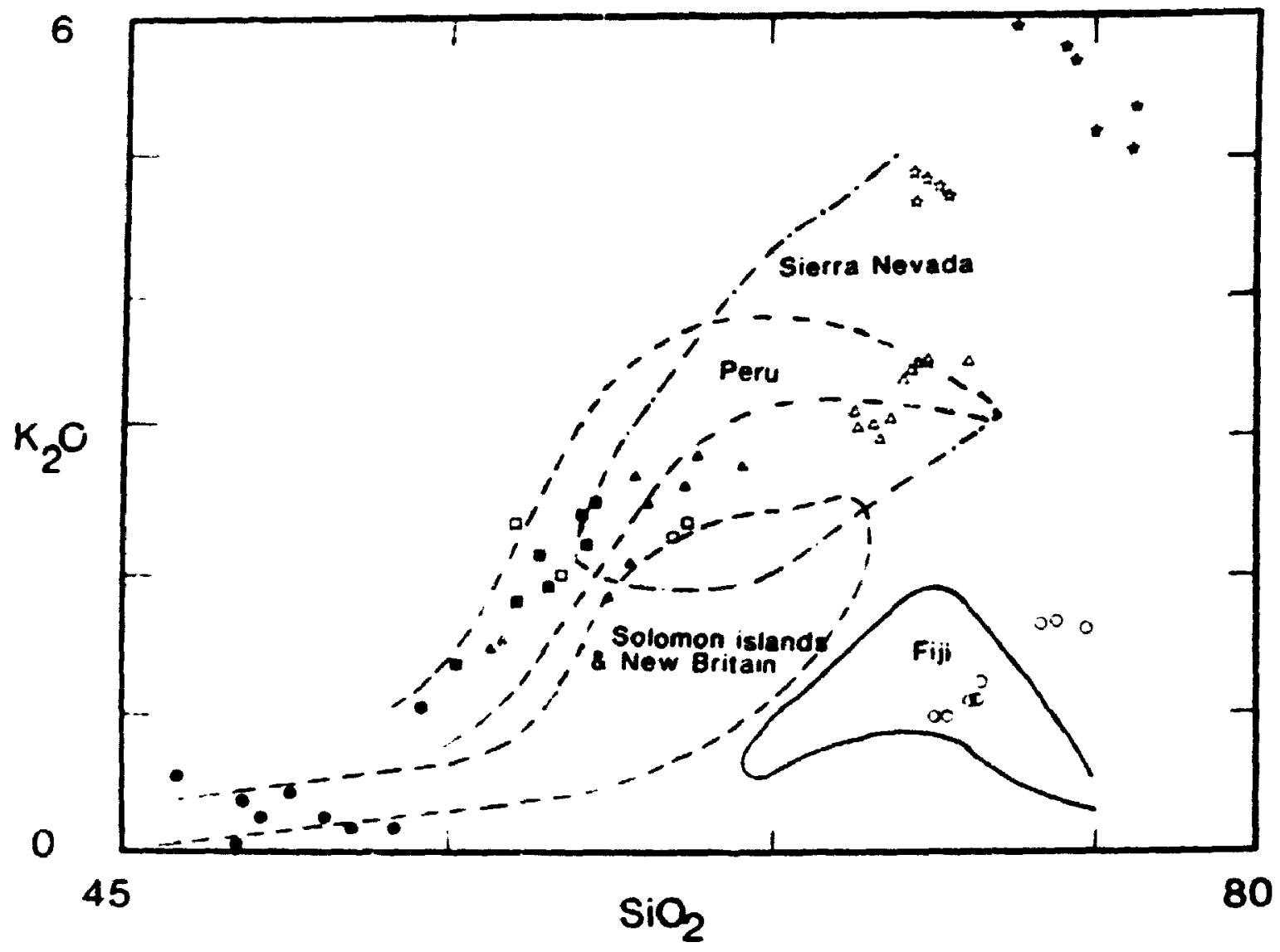

Figure 3.9: Plot of $\mathrm{K}_{2} \mathrm{O}$ - $\mathrm{SiO}_{2}$ variation diagram. Shown for comparison with ficlds for plutonic rocks from various destructive plate settings. Dara sources: Peru (Atherton et al. 1979). Sierra Nevada (Bateman and Dodge, 1970), Solomon Islands and New Britain (Hine and Mason, 1978), Fiji (Gill and Stork, 1979). Symbols same as in Fig. 3.1 (a). 


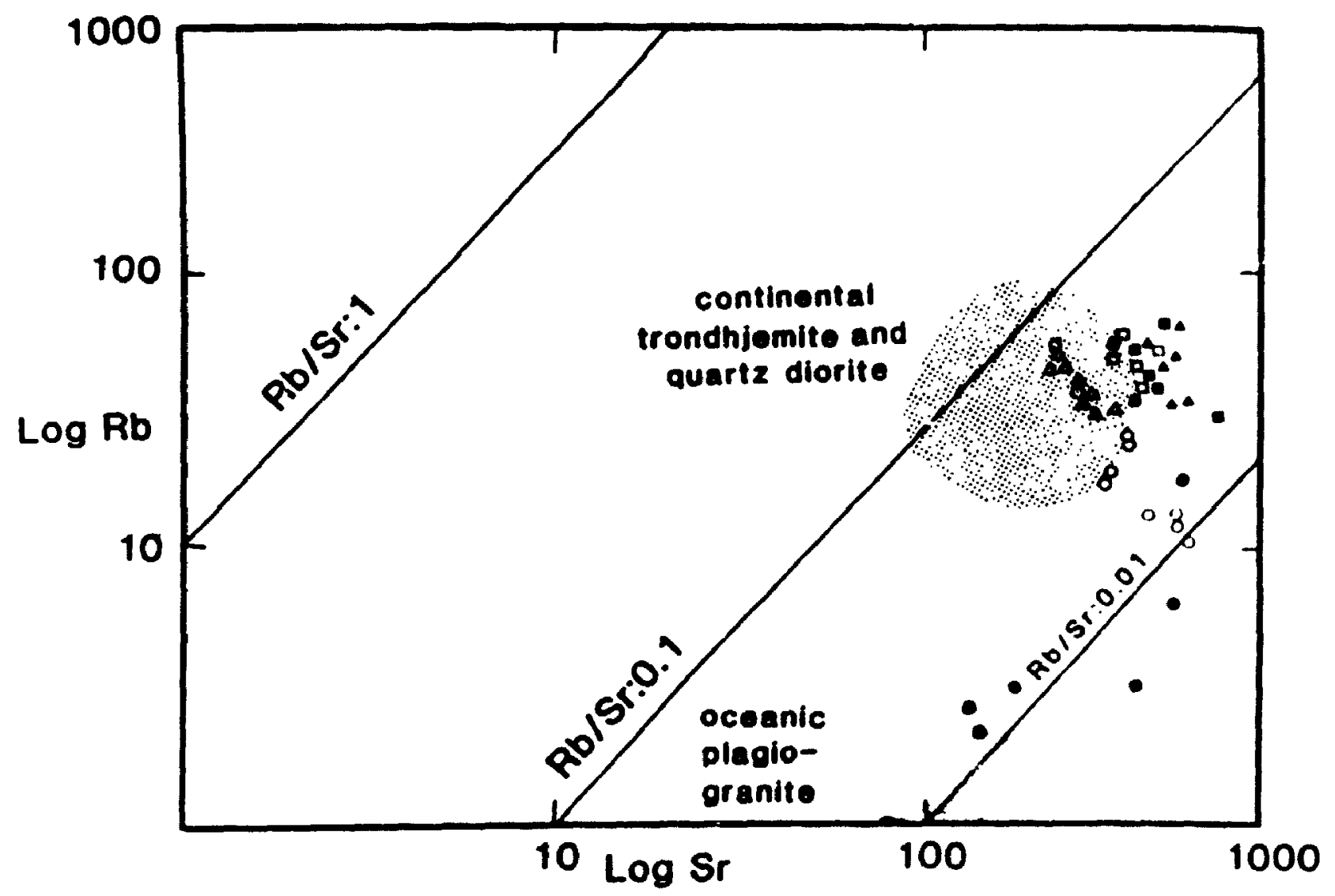

Figure 3.10: Rb and Sr covariation diagram (after Coleman and Peterman, 1975). The bimodal - low $K$ suite has compositions morc akin to those of occanic plagiogranites than to those of contincntal granophyres and trondhjemitcs. Symbols same as in Fig. 3.1 (a). 
Fiji tonalites described by Gill and Stork (1979) whereas the Bure rocks are very similar to gabbros from Solomon islands and New Britain both of which represent young, immature, ensimatic arcs. A $\mathbf{R b}$ and $\mathrm{Sr}$ co-variation diagram (Fig. 3.10) for Group (1) rocks shows that data points from the low-K suite scatter between the fields for ocesnic and continental trondhjemites. The calc-alkaline suite largely falls in the ranges shown by continental granitoid rocks.

Granites of Group (2) show chemical characteristics similar to those of syn-collisional peraluminous intrusions of (Harris et al., 1986). Of particular note are their high $\mathrm{Rb}, \mathrm{Ba}$ and $\mathrm{Ta}$, and low REE contents (Table 3.5 and 3.7). The presence in the Baro leucogranites of pelitic schlieren as well as substantial amounts of muscovite in the modal mineralogy suggest that they have originated by in-situ partial melting and thus they formed from a wet magma which could not have risen far through the crust without crystallizing. Their genesis is therefore attributed to anatexis of sialic crust, perhaps the metasedimentary schists and gneisses of the Baro Domain.

Group (3) rocks overlap those of Group (2) on plots of $R b$ vs $(Y+N b)$ and $\mathrm{Nb}$ vs $\mathrm{Y}, \mathrm{Rb}$ vs $(\mathrm{Y} b+\mathrm{Ta})$ and $\mathrm{Ta}$ vs $\mathrm{Yb}$ diagrams that indicate intraplate affinity for both groups. The source melts may have been generated during thermal relaxation in the lower erust and adiabatic decompression in the upper mantle; they could contain components from both crustal melting, including partial melting of the Group (1) pre-collision suite, and mantle melting (England and Thompson, 1986). 


\subsection{MINERAL CHEMISTRY}

Analyses of different minerals were undertaken in order to estimate magmatic or metamorphic temperature and pressure conditions of formation and, in the case of primary minerals, for testing whether differentiation has taken place by fractional crystallization. Compositions of plagioclase, K-feldspar, biotite, hornblende, apatite, epidote, garnet and muscovite were determined using an electron microprobe. Biotite and hornblende separates from the Birbir quartz diorite were also analysed by $X$-ray fluorescence and ferrous iron determinations were made by the modified Wilson cold acid method. The analyses are given in Appendix 3.

\subsubsection{Pressure and temperature of crystallization}

An attempt has been made to infer magmatic crystallization temperatures based on experimental determinations of alkali feldspar solubility relations for known pressures (Stormer, 1975; Whitney and Stormer, 1977). In order to estimate pressures of crystallization the normative rock compositions werc plotted in part of the "granite system" (Qz-Or-Ab- $\mathrm{H}_{2} \mathrm{O}$ system), projected onto the anhydrous base of the tetrahedron. Tuttle and Bowen (1958) showed that the minimum in the system is depressed and shifted away from quartz as $\mathrm{H}_{2} \mathrm{O}$ pressure increases. The quartz - feldspar liquidus cotectic boundarics are given for water pressures of 2,4 and $7 \mathrm{~kb}$ and for $\mathrm{Ab} / \mathrm{An}$ ratios of 1.8 and 5.2 (Fig.3.11; after Tuttle and Bowen, 1958 as modified by Anderson and Cullers, 1978). Assuming a melt, undersaturated with respect to $\mathrm{H}_{2} \mathrm{O}$, and assuming that those samples with highest silica content represent the most evolved compositions, an estimate can be made of the pressure of 
crystallization.

The post-metamorphic Bonga pluton contains large alkali feldspars, some up to $1 \mathrm{~cm}$, and subhedral-euhedral plagioclase laths with straight grain boundaries. The alkali feldspar is perthitic microcline. The pluton has $\mathrm{SiO}_{2}$ contents as high as 78 wt. \% and Differentiation Indices exceeding 95 , indicating that it is a highly evolved body. Apparent minimum melt compositions for the pluton suggest a minimum pressure of about $2 \mathbf{k b}$, and therefore minimum depth of emplacement of about $7 \mathrm{~km}$ (Fig. 3.11 ).

Orthoclase and albite become increasingly miscible with increasing temperature. In slowly cooled intrusions, albite exsolves from the alkali feldspar grains, and separates as unzoned plagioclase lamellae (Whitney and Stormer, 1977). The compositions of coexisting K-feldspar (microcline perthite) and plagioclase from sample T8K (Appendix 3) are Org2 $A b_{7} A n_{1}$ and $\mathrm{Ab}_{84} \mathrm{An}_{14} \mathrm{Or}_{2}$ (mole percent) respectively. These compositions plot outside all the solvi shown in Figure 3.12a, suggesting a.temperature of less than $400^{\circ} \mathrm{C}$ for unmixing.

Fluorine (F) - hydroxyl (OH) exchange in coexisting biotite-apatite pairs has been used to infer temperature conditions of metamorphism (Ludington, 1978). Figure $3.12 \mathrm{~b}$ shows the partitioning of $\mathrm{F}$ and $(\mathrm{OH})$ between coexisting biotite and apatite from intrusives of known equilibration temperature (Ludington, 1978). The hydroxyl content was esiimated from the structural formula for a given composition. Analyses of biotite and apatite from metamorphosed intrusive rocks of Group (1), the 


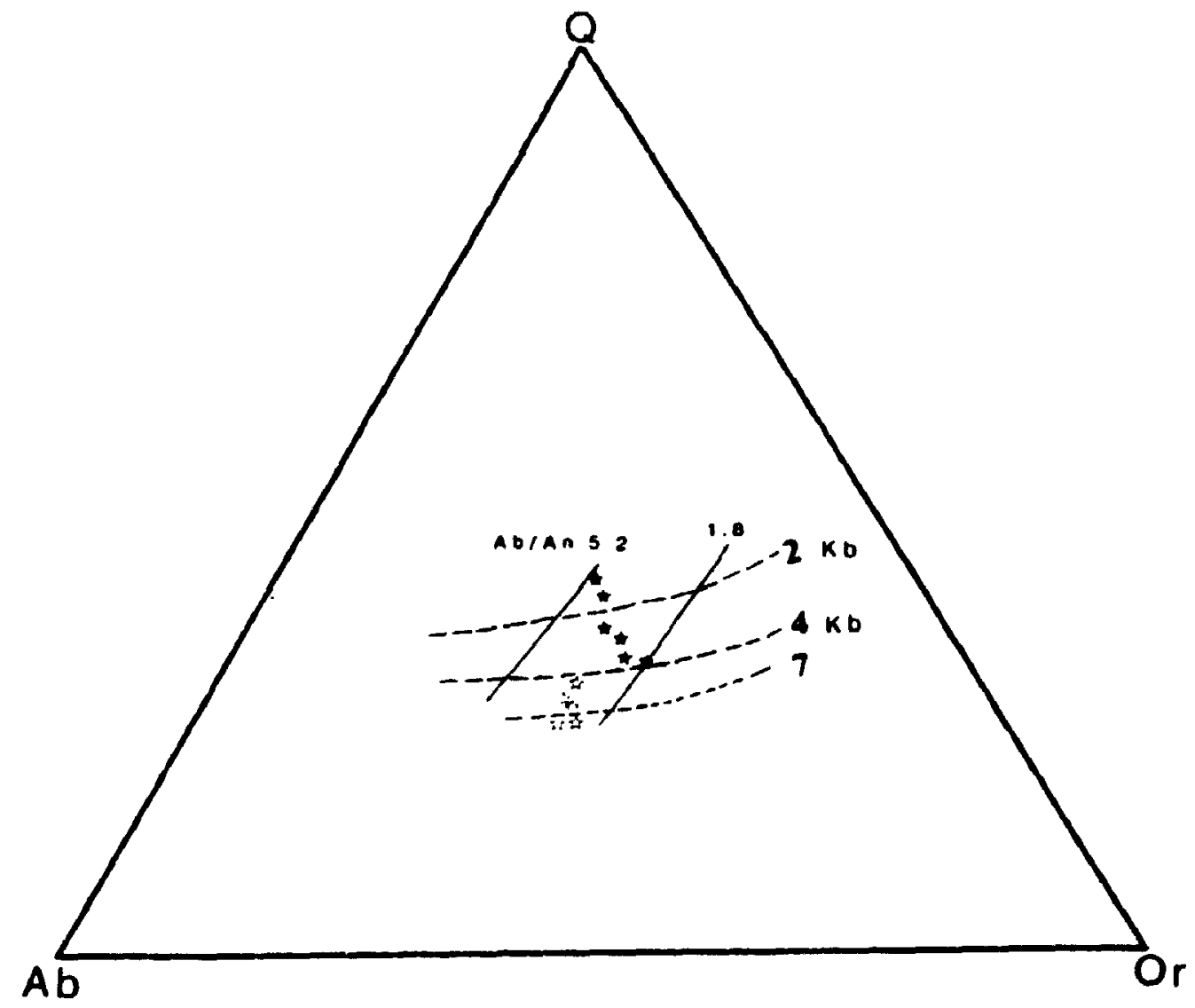

Figure 3.11: Normative quartz, albite and orthoclase of Mao and Bonga plutons in comparison to the minimum melt experimental grid compiled by Anderson and Cullers (1978). Open stars represent data from Mao pluton and solid stars that of Bonga pluton. 


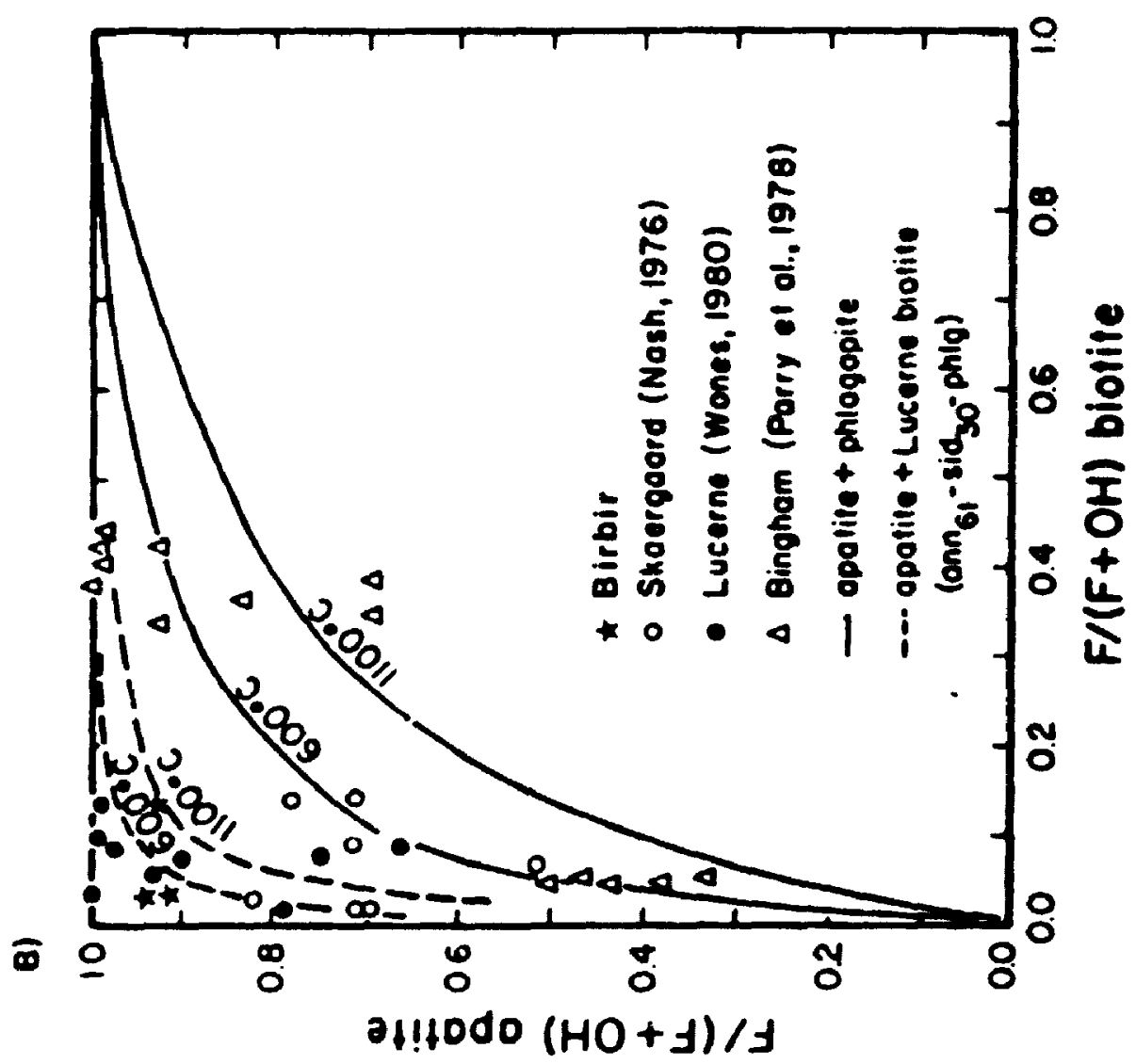

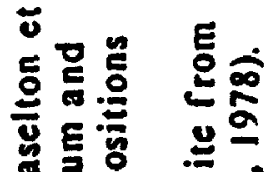
重总总 듀 음융 홍 号各

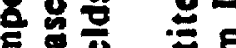
ㅌㅇㅇ현 过

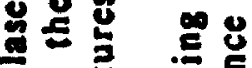
马든 웅

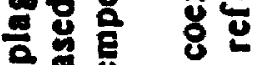
응 $20=.5$ 웅 을 可 ह 혼 E 웅 형은

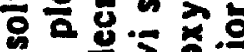

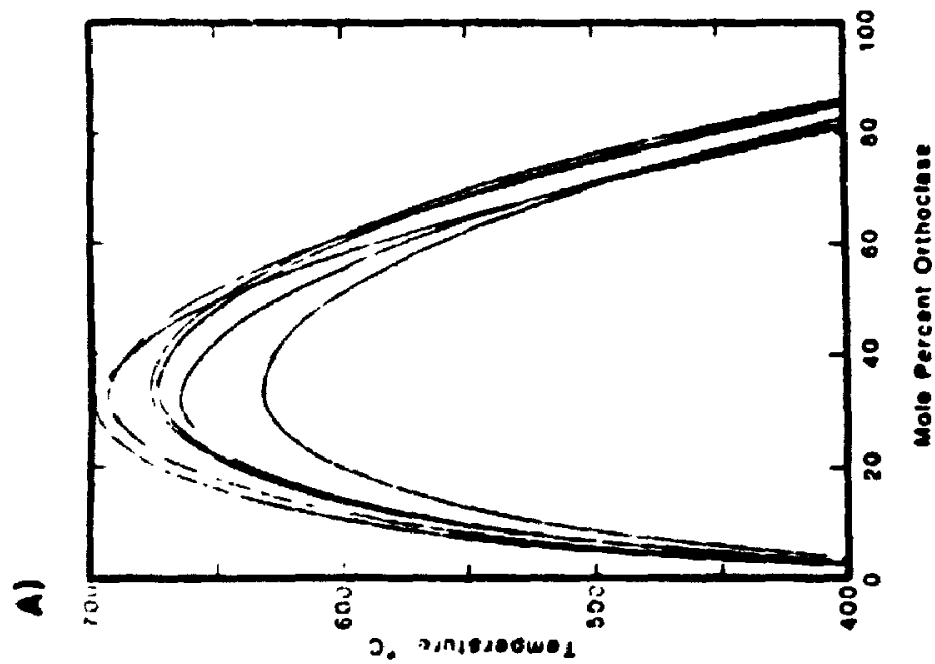

음응

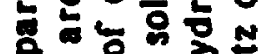

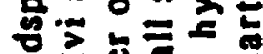
둥후일

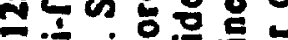

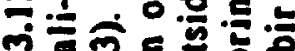
ㅆ요을 춘드음 춘후응 
Birbir quartz diorite, have been superimposed; two of the three analyzed pairs indicate a temperature less than $600^{\circ} \mathrm{C}$ (Fig. 3.12b). These values are consistent with metamorphic equilibration at no higher than mid-amphibolitc grade.

E-an Zen and Hammarstrom (1984) and other petrologists have suggested that epidote, commonly regarded as a metamorphic mineral, can be a magmatic product in granitoid rocks. Epidote crystals that secm to satisfy the criteria for magmatic epidote are described in Chapter 2. Diagnos ic features include the common association of epidote with mafic minerals. euhedral contacts against biotite, and resorption of hornblende in contact with euhedral epidote and wormy intergrowth with plagioclase.

Average values of seven representative analyses of epidote from sample T9G (Appendix 3) are listed in Table 3.10 along with three analyses from magmatic epidote cited by Zen and Hammarstrom (1984, 1986). There is little difference between the two groups of analyses.

The occurrence of magmatic epidote has been used as an indicator of emplacement depths around 25-30 km (Naney, 1983). Mineral assemblages in the country rocks of epidote-bearing Group (1) plutons indicate a maximuin regional metamorphic grade of lower amphibolite facies, suggesting that the depth of burial of these rocks did not exceed about $15 \mathrm{~km}$. If the inferences of Zen and Naney are applicable to Group (1) rocks, there was substantial uplift between the time of their emplacement and their regional metamorphism in the Birbir Shear Zone (BSZ). 
Table 3.10: Average microprobe analysis of epidote from sample T9G of the Birbir complex (mqd) compared to Zen and Hammarstrom's (1986) representative analyses of magmatic epidote (Analyses $\$ 1,2$ and 3 ).

mad

$\mathrm{SiO}_{2}$
$\mathrm{Al}_{2} \mathrm{O}_{3}$
$\mathrm{FeO}_{3} \mathrm{~T}$
$\mathrm{MgO}$
$\mathrm{CaO}$
$\mathrm{Na}_{2} \mathrm{O}$
$\mathrm{TiO}_{2}$
$\mathrm{MnO}^{-}$
$\mathrm{F}$

Total
37.75

23.99

12.02

0.03

22.74

0.05

0.11

0.20

0.11

97.07
(1)

$$
37.29
$$

23.62

13.95

24.26

0.01

0.16

0.22

-

99.51
(2)

$$
37.51
$$

25.99

12.40

0.14

23.01

-

0.05

0.34

0.03

99.46
97.88

(3)

36.64

23.62

13.69

23.34

0.08

0.49

0.03 


\subsection{PETROGENESIS}

Fourcade and Allegre (1981) point out the difficulties involved in the petrogenetic modelling of plutonic rocks in comparison with volcanic complexes. During volcanic activity, the frequent sampling of the magmatic reservoir by eruptions enables a more or less continuous evolution in the chemistry of the liquid to be monitored. Granitoids, on the other hand, commonly represent the end products of the chamber itself which may consist of various mixtures of cumulate solids and crystallized liquid. In addition. postmagmatic textural and chemical changes or the metamorphosed nature of the intrusive units make it difficult to infer their history from the bulk composition. Thus, the testing of differentiation and/or fractional crystallization models in the section to follow should be viewed as preliminary.

\subsubsection{Mafic and intermediate intrusive complexes: Growp (1)}

Harker diagrams of data from the calc-alkaline suite (Fig. 3.6) definc approximate linear trends for most major elements, that suggest fractionation. Petrographic data for the calc-alkaline suite of Group (1) indicate that plagioclase, biotite, and hornblende are the significant primary and early-crystallizing phases. Most apatite and titanite arc poikilitically enclosed in the biotite and hornblende, suggesting their erystallization from a melt. Fractionation of hornblende and plagioclase can explain the decrease in $\mathrm{CaO}$ and $\mathrm{Sr}$ with increased $\mathrm{SiO}_{2}$. The decrease in $\mathrm{MgO}$. $\mathrm{FeO}, \mathrm{P}_{2} \mathrm{O}_{5}$, and $\mathrm{TiO}_{2}$ as $\mathrm{SiO}_{2}$ increases appears to be controlled through fractionation of biotite, hornblende, apatite and titanite. 
The calc-alkaline suite also shows little or no negative Eu anomaly, and small LREE/HREE ( - La/Lu(cn) ratios. These low ratios could be produced by partial melting of a mafic source involving minerals with low LREE/HREE ratios, or fractional crystallization of plagioclase from less differentiated melts with low LREE/HREE ratios (Cullers and Graf, 1986). According to Hanson (1980) europium anomalies could have been prevented in these plagioclase-rich rocks, in one of three ways: (1) large concentrations of Sr and Ba (2) fractionation of hornblende together with plagioclase or (3) a low oxygen fugacity of the melt. The oxygen fugacity during the crystallization of these rocks appears to be low, a condition inferred from the absence of magnetite and ilmenite from the modal mineralogy of these rocks.

The low-K suite is Fe-poor and Na-rich. Similar trends have been described from an are-type setting where crystal-liquid fractionation of magmas near the base of the crust is one way of suppressing the tholeiitic Fe-enrichment trend, and resulting in the calc-alkaline trends ( $R$ ingwood, 1977; Jackson, 1986).

\subsubsection{Quantitative modeliag of major elements in the calc- alkaliae suite}

Fractional erystallization can be used to model the calc-alkaline suite, represented by the Birbir quartz diorite complex and Goma pluton. The model was evaluated using whole-rock and mineral compositions that involve mass balance calculations using the least-squares computer program XLFRAC, a program used for the interactive testing of magmatic differentiation models (Stormer, 1978). The calculation was made using only major 
TABLE 3.8: Hypothetical liquid compositions in the calc-alkaline suite

$\begin{array}{lcccc} & \text { QL1 } & \text { QL2 } & \text { QL3 } & \text { QL4 } \\ \mathrm{SiO}_{2} & 55.0 & 60.0 & 65.0 & 70.0 \\ \mathrm{TiO}_{2} & 0.86 & 0.71 & 0.56 & 0.41 \\ \mathrm{Al}_{2} \mathrm{O}_{3} & 17.8 & 16.8 & 15.98 & 15.1 \\ \mathrm{Fe}_{2} \mathrm{O}_{3} & 9.13 & 7.02 & 4.91 & 2.80 \\ \mathrm{MnO} & 0.16 & 0.13 & 0.10 & 0.08 \\ \mathrm{MgO} \mathrm{O} & 3.99 & 2.85 & 1.71 & 0.57 \\ \mathrm{CaO}_{2} \mathrm{O} & 7.69 & 5.68 & 3.67 & 1.65 \\ \mathrm{Na}_{2} \mathrm{O} & 3.22 & 3.87 & 4.52 & 5.16 \\ \mathrm{~K}_{2} \mathrm{O} & 1.69 & 2.30 & 2.91 & 3.52 \\ \mathrm{P}_{2} \mathrm{O}_{5} & 0.2 & 0.17 & 0.14 & 0.11\end{array}$


elements.

Hypothetical liquid compositions were compiled by reading the concentrations of the various component oxides from the Harker diagrams (Fig. 3.6) at four equally spaced silica values that span the observed compositional range. The oxides were then normalized to $100 \%$. The liquid compositions are designated QL1 to QL4 (Table 3.8). Microprobe analyses of plagioclase, hornblende, biotite, and apatite are used to represent compositions of the early-formed phases that were subtracted from the derivative melt during fractional crystallization. Proportions of the crystallizing phases and compositions of residual liquid were then calculated using the XLFRAC program.

The composition of QLI was chosen as an approximation to the initial melt composition, differentiating successively to QL2, QL3 and QL4. Given two successive magma compositions, such as QL1 and QL2 and four mineral phases, the pros,ram determines the most likely amounts of phases that may have fractionated, and which must be subtracted to produc: the observed difference between each composition.

Several criteria are used to evaluate the results of the ieast-squares mass-balance calculation. The sum-of-the-squares of the residuais, a statistical parameter, is the quantity that is minimized by the program. A low value is generally indicative of a good solution. It is impossible to give an absolute value for all cases which indicate an acceptable solution, but generally solutions with low values $(<2)$ are better than ones with high values (>5) (Stormer, 1978). The proportions, as well as compositions, of precipitated minerals and the residual liquid for each one of the silica 
Table 3.9: Testing the feasibility of fractional crystallization in mqd.

Recalculated analyses (Wt. \% basis)

Observed - calculated = Residuals

$\begin{array}{lrcr} & \text { QL110 QL2 } & \text { QL2 to QL3 } & \text { QL3 10 QL4 } \\ \mathrm{SiO}_{2} & -0.115 & -0.36 & -0.053 \\ \mathrm{TiO}_{2} & -0.381 & -0.336 & -0.147 \\ \mathrm{Al}_{2} \mathrm{O}_{3} & -0.209 & -0.072 & -0.058 \\ \mathrm{FeO} & 0.337 & 0.196 & 0.132 \\ \mathrm{MnO} & 0.029 & 0.015 & 0.019 \\ \mathrm{MgO} & -0.707 & -0.341 & -0.271 \\ \mathrm{CaO} & -0.227 & -0.105 & -0.084 \\ \mathrm{Na}_{2} \mathrm{O} & 0.983 & 0.472 & 0.368 \\ \mathrm{~K}_{2} \mathrm{O} & 0.145 & 0.099 & 0.044 \\ \mathrm{P}_{2} \mathrm{O}_{5} & 0.144 & 0.108 & 0.050\end{array}$

Sum of the squares of the residuals
1.876
0.530
0.266

Amount as weight percent of subtracted phases

$\begin{array}{lrrr}\text { plagioclase } & 45.23 & 44.04 & 45.28 \\ \text { hornblende } & 50.19 & 50.67 & 50.64 \\ \text { biotite } & 3.52 & 3.94 & 3.06 \\ \text { apatitc } & 1.07 & 1.35 & 1.02\end{array}$


compositions were calculated. The results for major element fractionation are presented in Table 3.9. In all cases the sums of the squares of the residuals are less than 2 suggesting a good fit of the calculated compositions with those that were obtained for the variation diagram. The sum-of-the-squares of the difference between the observed and calculated values is 1.88 for QL1 to QL2, 0.53 for QL2 to QL3, and 0.27 for QL3 to QL4. The results of the mass-balance calculation are thus consistent with fractional crystallization produciag the calc-alkaline suite, in which plagioclase, hornblende, biotite and apatite were the main fractionating minerals.

\subsubsection{Origin of the Bipbir intrusive complex}

Chemical data indicate that Group (1) rocks represent the products of magmatic arc plutonism. Field relations suggest that these intrusive rocks are pre- to syn-kinematic. In terms of $\mathrm{Rb}-\mathrm{Sr}, \mathrm{K}_{2} \mathrm{O}-\mathrm{SiO}_{2}$ and other chemical variables the calc-alkaline suite is considered to be the result of magmatism in an Andean-type continental margin whereas the low-K suite displays chemical characteristics of intrusive rocks identified with an oceanic environment.

The origin of the low-K suite is uncertain. It could be: 1) part of an oceanic island are suecession, 2) the product of an incipient rift representing transitional material along an attenuated continental margin or 3) the upper fart of an ophiolite suite. Considering the $\mathbf{K}_{2} \mathrm{O}$ content is relatively high for ophiolitic rocks, an island arc or back-arc basin mode of development is preferred. This choice is also supported by the nature of 
the associated sedimentary material. The spatial coincidence of the calc-

alkaline suite with the Birbir Shear Zone and the presence nearby of metasedimentary rocks (quartz - muscovite schist and conglomerate (qms)) sugsestive of a continental shelf environment imply that the eastern boundary of the Baro Domain marks a continental margin. The presence of predominant wackes and pelites (mss), further east in the Birbir Domain. suggest an intraoceanic environment for the low-K suite.

Numerous models have been proposed for the origin of orogenic granites. These fall into one of three groups: (1) extraction directly from the mantle; (2) reworking of older continental crust; and (3) mixing of both mantle and crustal components. Wyllie et al. (1976) and Wyllic (1977) described phase relationships for granites and tonalites and showed that liquids less siliceous than granodiorite composition can not be generated by crustal anatexis under conditions of normal regional metamorphism. The chemical evolution of are-type rocks is generally considered to be the result of the complex interplay of deep continental crust, subducted oceanic crust and the mantle wedge above a subduction zone, in restionse to the introduction of water and volatiles from the dehydrating slab of subducted oceanic lithosphere (Ringwood, 1974, 1977; Mysen, 1979).

According to Brown (1982), the space-time trends of granitoid rocks from modern compressional arcs reflect a siage of plutonism in oceancontinent arc settings, where dominant cale-alkaline magmas intrude mature continentalized margins with or withou' ancient sialic basement. Brown described overlapping tectonic and geochemical zones in South America and New Guinea; these are (1) an arc founded on oceanic crust which contains 
diorites and low-K granodiorites; (2) an elongate thrust zone with quartz diorite and granodiorite that follow more closely the medium-K calc-alkaline trend of the Andean batholiths, and (3) the continental arc, where a high-K series of granitoid rocks intrudes the crystalline basement.

Zones (1) and (2) of Brown (1982) provide contemporary analogues that could represent the complete range of magma types for the low-K and calcalkaline suites in the Birbir Domain. These two suites are strongly deformed, and their age relations cannot be inferred. Although the relative age of these bodies is unknown, if they are cogenetic then the low-K suite is best interpreted as predating the calc-alkaline suite.

Similar chemical paths to those deduced from the Birbir intrusive rocks have been documented by many workers (see Best, 1975; Gill, 1981; Mysen, 1979). The stages of development are: (1) progressive thickening of the continental crust above the subduction zone, upward migration of mantlederived basaltic magma, and amphibole-pyroxene controlled, calc-alkaline fractionation; (2) change in the composition of the melt in the mantle wedge, with progressive enrichment in LIL elements and volatiles as more material is added from the subducted slab that is undergoing dehydration. The melt generated during subduction has a relatively high oxygen fugacity, thus Fe-enrichment in the crystallizing phases is suppressed. The early melts have tonalitic or trondhjemitic affinities (e.g Fiji: Gill and Stork, 1979). similar to the low-K suite. The Haya tonalites could represent the felsic magmas generated by partial melts of tholeiitic crust, the 
forerunners of arc magmatism.

\subsubsection{Peraluminous granite sulte: Group (2)}

Chemical trends for rocks of Group (2) differ markedly from Chappell and White's (1983) peraluminous rocks as well as the metaluminous calcalkaline suite of Group (1) and alkali-feldspar granite of Group (3). There is no sign that these rocks were derived from a more mafic parent, as discussed in previous sections and Chapter 2. Crustal sources with a significant metasedimentary component are of ten invoked for peraluminous melts (Hine et al., 1978; Clarke and Halliday, 1980). Low $\mathrm{Na}, \mathrm{Ca}$ and $\mathrm{Sr}$ abundances, characteristic of these rocks, agree with what would be expected from sedimentary rock sources, as these elements are removed in solution during chemical weathering. Clemens and Wall (1981) described granites with chemical characteristics such as high $\mathrm{K}_{2} \mathrm{O} / \mathrm{Na}_{2} \mathrm{O}$, low $\mathrm{CaO}$ and $\mathrm{Sr}$ content. similar to analyses from Group (2). They considered these granites to be the product of anatexis of aluminous high-grade metamorphic rocks. The peak pressure and temperature in unit (gsg) (see Chapter 2 for details) reached minimum melting conditions for rocks of quartzof eldspathic composition. At temperatures above the muscovite - quartz stability field, partial melting in high-grade metamorphic rocks of peraluminous compositions involves sillimanite, garnet, cordierite, biotite, quartz and feldspars (Clemens and Wall, 1981) similar to the assemblages described from unit (gsg). One possible equilibrium reaction for the assemblage is: 
Biotite + sillimanite + quartz + feldspar = garnet $(+/$-cordierite $)$

+ K-feldspar + melt $+/$ - water $\quad$ (Froese, 1973)

The garnet-bearing schilieren within the Baro leucogranites could represent partially digested inclusions, or a residual crystalline assemblage.

\subsubsection{Alkali-feldspar grasite sulte: Group (3)}

Group (3) plutons post-date regional metamorphism. Low confining pressure during emplacement is inferred for the Bonga pluton from two lines of evidence. The most evolved compositions, with Differentiation Indices of 94, indicate crystallization at pressures less than $2 \mathrm{~kb}(-7 \mathrm{~km})$. Granitic magmas increasingly approach the "ternary" minimum composition with increasing differentiation (Tuttle and Bowen, 1958). The absence of pegmatitic phases within the Bonga pluton suggests that the melt was vapourundersaturated, with an $\mathrm{H}_{2} \mathrm{O}$ content of less than $1.5 \mathrm{wt} . \%$ (Maaloe and Wyllic, 1975; Burnham, 1979).

The compositional field of the Mao pluton indicates pressures of about 2 to $4 \mathrm{~kb}(7.5$ to $15 \mathrm{~km})$ and could reflect fusion in the lower levels of a thickened crust. The lower amount of normative quartz, in the less differentiated Mao pluton, is expected because higher pressure conditions shift the pressure sensitive quartz-feldspar boundary plane (Presnall and Bateman, 1973). The felsic nature of this pluton indicates that it is probably still on the intersection of the two-feldspar and quartz-feldspar planes, not far removed from minimum melt composition.

The alkaline affinity of Group (3) rocks, indicated by major elements 
and high $\mathrm{Zr}$ and $\mathrm{Nb}$ (i.e. $\mathrm{Zr}>200 \mathrm{ppm} ; \mathrm{Nb}>15 \mathrm{ppm}$ ), suggests a possible derivation from an igneous source that had previously been partially melted (Pitcher, 1981). Altogether the field relations and chemistry suggest an epizonal plutonic emplacement as product of partial fusion of sialic crust. 


\section{CHAPTER 4}

\section{GEOCHRONOLOGY AND ISOTOPE GEOCHEMISTRY}

\subsection{GENERAL STATEMENT}

Isotopic dating of intrusive and metamorphic events in the Precambrian rocks of Ethiopia is at a reconnaissance stage. The available data, from southern and northern Ethiopia only, are mostly either K-Ar or Rb-Sr mineral dates. The few published dates available are summarized in Table 4.1. Most results fall between 700 and $450 \mathrm{Ma}$. Prior to the present study, no geochronological data were available from the study area or from elsewhere in the Western Ethiopian Shield.

The high-grade rocks of the Western Ethiopian Shield have been regarded as the northward continuation of the Mozambique Belt, representing basement unconformably underlying the lower-grade metamorphic rocks of the Birbir Domain (Kazmin, 1971). The lower-grade calc-alkaline sequences and ophiolitic rocks, however, are without a recognizable older substrate.

Kroner (1977, 1979), Hepworth $(1979,1980)$ and many others consider the Mozambique Belt to be an ensialic mobile belt, polycyclic in origin, which contains reworked older crust. Shackleton (1986) regarded the Mozambique Belt to be a complex assemblage of Proterozoic belts of different ages, and argued that the strong Pan-African deformation and metamorphism has obliterated Archean and early Proterozoic dates within the belt.

The present geochronologic data neither support nor refute the view that the high-grade gneissic rocks thought to be Mozambiquian are older than the juxtaposed lower-grade (Pan-African?) rocks. The oldest event documented 
Table 4.1: Isotopic age determinations of Precambrian rocks in Ethiopia.

\begin{tabular}{|c|c|c|c|c|c|}
\hline $\begin{array}{l}\text { LITHPTECTONIC } \\
\text { UNIT }\end{array}$ & LOCALITY & ROCK TYPE & & \multicolumn{2}{|c|}{$\begin{array}{c}\text { METHOD AGE/DATE } \\
(\text { Min })\end{array}$} \\
\hline $\begin{array}{l}\text { Southern gneiss } \\
\text { zone }\end{array}$ & $\begin{array}{l}\text { El-Der, } \\
\text { Sidamo }\end{array}$ & Hbd-Bi gnciss & $\mathbf{B i}$ & $\mathbf{K}-\mathbf{A r}$ & $739+i \cdot 15(1)$ \\
\hline 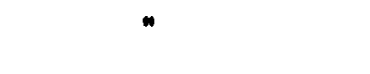 & $n$ & Amphibolitc & WR & $"$ & $637+/ \cdot 20$ \\
\hline$"$ & $\begin{array}{l}\text { Neghelli, } \\
\text { Sidamo }\end{array}$ & Bi gnciss & $\mathrm{Ei}$ & $"$ & $507+1.5$ \\
\hline $\begin{array}{l}\text { Adola magmatic } \\
\text { zone }\end{array}$ & $\begin{array}{l}\text { Moyale, } \\
\text { Sidamo }\end{array}$ & Quartz diorite & Bi & $"$ & $517+1-5$ \\
\hline$"$ & $\begin{array}{l}\text { Mormora R.. } \\
\text { Sidamo }\end{array}$ & Granitc & $\mathrm{Bi}$ & $"$ & $+95+/-20(2)$ \\
\hline $\begin{array}{l}\text { Yavello para- } \\
\text { gneiss zone }\end{array}$ & $\begin{array}{l}\text { Gariboro, } \\
\text { Sidamo }\end{array}$ & Granitc & WR & $\mathrm{Rb}-\mathrm{Sr}$ & $680+/ .10(3)$ \\
\hline$"$ & " & Granite & WR & $"$ & $515+/-10$ \\
\hline 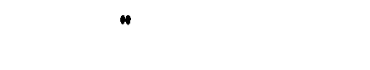 & $"$ & Pegmatite & Ms & $"$ & $530+/-10$ \\
\hline $\begin{array}{l}\text { Northern } \\
\text { volcanic- } \\
\text { sedimentary } \\
\text { terrane }\end{array}$ & $\begin{array}{l}\text { Zula, } \\
\text { Eritrea } \\
\end{array}$ & Granitc & Bi & $\mathrm{K} \cdot \mathrm{Ar}$ & $976(4)$ \\
\hline$"$ & $\begin{array}{l}\text { Hauzien, } \\
\text { Tigre }\end{array}$ & Granitc & $\mathrm{Bi}$ & $"$ & $583+1 .-20(5)$ \\
\hline$"$ & $\begin{array}{l}\text { Adigrat, } \\
\text { Tigre }\end{array}$ & Quartz diorite & $\mathbf{B i}$ & $"$ & $582+/-22$ \\
\hline$"$ & $\begin{array}{l}\text { Mareb V.. } \\
\text { Eritrea }\end{array}$ & Granodioritc & $\mathrm{Bi}$ & $"$ & $627+/-10(6)$ \\
\hline \multicolumn{6}{|l|}{1 sce Chapter 6} \\
\hline 2 Sources of data: & \multicolumn{2}{|c|}{$\begin{array}{l}\text { (1) Rogr.s ct al., } 1965 \\
\text { (2) Jelcrc, } 1966 \\
\text { (3) Gilboy, } 1970 \\
\text { (4) Frazicr, 1970 } \\
\text { (5) Ethiopian Institute o } \\
\text { (6) Millcr ct al., } 1967\end{array}$} & gic: & rveys & \\
\hline
\end{tabular}

WR: whole-rock, Bi: biotite, Ms: muscovitc, Hbd: hornblendc 
from Pan-African rocks in the region is $1165 \mathrm{Ma}$ (Rb-Sr whole-rock isochron age from metavolcanic rocks in Saudi Arabia; Fleck et al., 1980). Rb-Sr whole-rock isochrons from volcanics in eastern Egypt, yielded youngest dates from 710 to $610 \mathrm{Ma}$ (Stern, 1979). The oldest reported date of PanAfrican granitoid rocks from the region is a Rb-Sr whole-rock isochron of $960 \mathrm{Ma}$ (southern Saudi Arabia; Greenwood et al., 1976). The more fractionated granitoid rocks from southern Saudi Arabia have been dated at 785 - $600 \mathrm{Ma}$ (Greenwood et al., 1976) and from southeastern Egypt at 670 . $620 \mathrm{Ma}$ (Stern, 1979). Younger rocks include alkali-rich granites dated at 590 to $550 \mathrm{Ma}$ (Fullagar and Greenberg, 1978; Abdel Monem and Hurley, 1979).

Gneisses at Ouweinat, west of Pan-African rocks at $25^{\circ} \mathrm{E}, 22^{\circ} \mathrm{N}$, were dated by the U-Pb method at $2600 \mathrm{Ma}$ by Klerkx and Deutsch (1977). Kroner et al. (1987) reported ion microprobe ages of detrital zircons that range from ca. 1000 to $2650 \mathrm{Ma}$. The zircons were separated from a high-grade gneiss terrane at Sabaloka on the Nile river north of Khartoum, Sudan. A U-Pb zircon date of $1700 \mathrm{Ma}$ has been reported from psammitic gneisses of the Jabal Hafafit group of eastern Egypt (Dixon, 1981), a fine-grained granodiorite in the eastern edge of the Arabian shield yielded a zircon U-Pb date of $1630 \mathrm{Ma}$ (Stacey and Hedges, 1984). These dates were reinforced by model Nd ages that yielded $1800 \mathrm{Ma}$ from metapelites in eastern Egypt and 1550 Ma from quartzofeldspathic metasediments in the Bayuda desert of Sudan (Harris et al., 1984).

None of the documented accounts about the Mozambique Belt has been able to assess the time of amphibolite and granulite metamorphism with any degree of certainty. The dates of the latest metamorphism of the Mozambique Belt 
rocks in NW Kenya indicate much younger events (ca. $580 \mathrm{Ma}$; Ries et al., unpublished) than the metamorphic ages of the Pan-African rocks of NE Africa (ca. 760 Ma; Ries et al., 1985). Suwa (1979) obtained a Rb-Sr whole-rock date on gneissic granite from central Kenya of $766+/-29 \mathrm{Ma}$, while Leg80 (1974) interpreted a lower concordia intercept of $650 \mathrm{Ma}$ as the time when the PanAfrican tectono-thermal event affected the Ugandan basement. A similar pattern has been recorded from Tanzania, where a U-Pb zircon lower intercept of $652+/-10 \mathrm{Ma}$ is thought to be the age of the granulite facies metamorphism (Coolen et al., 1982). These late Proteruzoic dates from the Mozambique Belt and the Pan-African rocks in NE Africa contrast with those from the craton to the west in Uganda and Tanzania, where Rb-Sr whole-rock ages of ca. $2.7 \mathrm{Ga}$ and $\mathrm{U}-\mathrm{Pb}$ zircon ages up to ca. $2.9 \mathrm{Ga}$ have been determined (Spooner et al, 1970; Leg80, 1971, 1974; Bell and Dodson, 1981).

\subsection{INTRODUCTION}

$\mathrm{U}-\mathrm{Pb}$ zircon and $\mathrm{R}$ b-Sr whole-rock and mineral dating have been carried out in an attempt to learn the time of intrusion of the plutons in the GoreGambella area, and their subsequent history. In addition, the isotopic data from these granitoid rocks contributes to an understanding of the regional age framework.

The present isotopic work identifies distinet periods of plutonism and tectonic activity throughout the Birbir Domain and the Baro Domain, where detailed mapping has provided structural control on a complete cross section across the western Ethiopian Shield (see Chapter 2). Three generations of granitoid rocks are recognized on the basis of field relations and 
geochemical data. The earliest consists of pre-kinematic, arc-type mafic and intermediate intrusive complexes in the Birbir Domain. The second group is made up of anatectic granites from the high-grade metamorphic rocks of the Baro Domain. The third group consists of late- to post-kinematic plutons that occur in both domains. Petrographic study, and major and trace element analyses were performed on all of the samples that were used for the isotopic work (Appendices 1 and 2).

\subsection{U-Pb ANALYSES OF ZIRCON AND THE CONCORDIA DIAGRAM}

U-Pb zircon ages were determined of five plutonic units, The data are listed in Table 4.2 and plotted on concordia diagrams (Figs. 4.1 - 4.5).

Zircon is used in $\mathrm{U}-\mathrm{Pb}$ dating because it is widely distributed in many rocks and exhibits atomic substitution of $U^{+4}$ for $\mathrm{Zr}^{+4}$ whereas $\mathrm{Pb}^{+2}$ is essentially excluded from the mineral during crystallization. The greatest geological interest in zircon stems from its common ability to retain $\mathrm{U}, \mathrm{Pb}$ and intermediate decay products over geologic time, i.e. preserve its isotopic signature, despite partial melting or high grade metamorphism to temperatures as high as $800^{\circ} \mathrm{C}$ (Speer, 1982).

$\mathrm{Pb}$ has four naturally occurring isotopes of which only ${ }^{204} \mathrm{~Pb}$ is considered non-radiogenic. The decay of the two radioactive uranium isotopes ${ }^{238} \mathrm{U}$ and $235 \mathrm{U}$ to their respective daughter products $206 \mathrm{~Pb}$ and $207 \mathrm{~Pb}$ can be expressed in the form of two equations (Faure, 1986):

$$
\begin{aligned}
& { }^{206} \mathrm{~Pb} /{ }^{204} \mathrm{~Pb}=\left({ }^{206} \mathrm{~Pb} / 204 \mathrm{~Pb}\right)_{0}+{ }^{238} \mathrm{U} /{ }^{204} \mathrm{~Pb}\left(e^{\lambda_{1} t}-1\right) \\
& { }^{207} \mathrm{~Pb} /{ }^{204} \mathrm{~Pb}=\left({ }^{207} \mathrm{~Pb} /{ }^{204} \mathrm{~Pb}\right)_{0}+{ }^{235} \mathrm{U} /{ }^{204} \mathrm{~Pb}\left(e^{\lambda_{2} t}-1\right)
\end{aligned}
$$


where:

${ }^{206} \mathrm{~Pb} /{ }^{204} \mathrm{~Pb},{ }^{207} \mathrm{~Pb} /{ }^{204} \mathrm{~Pb}=$ isotope ratios of lead in the mineral at the time of analysis; $\left({ }^{206} \mathrm{~Pb} /{ }^{204} \mathrm{~Pb}\right)_{0} \cdot\left({ }^{207} \mathrm{~Pb} /{ }^{204} \mathrm{~Pb}\right)_{0}$ - initial isotope ratios of lead incorporated into the mineral at the time of its formation; ${ }^{238} \mathrm{U} /{ }^{204} \mathrm{~Pb}$, ${ }^{235} \mathrm{U} /{ }^{204} \mathrm{~Pb}=$ isotope ratios in the mineral at the time of analysis; $\lambda_{1}, \lambda_{2}=$ decay constants of ${ }^{238} U$ and $235 U$, respectively; $t$ = time clapsed since closure of the mineral to uranium, lead and all intermediate daughters.

The ratios ${ }^{206} \mathrm{~Pb} * 238 \mathrm{U}$ and ${ }^{207} \mathrm{~Pb} * / 235 \mathrm{U}$ (": radiogenic lead) can be calculated for any given time, $t$. Plotting these two values for all $t$ yields a curved locus of points called concordia (Wetherill, 1956). Any system which has not suffered uranium or lead disturbance should plot on this curve. A system that yields similar ${ }^{238} \mathrm{U}$ and ${ }^{235} \mathrm{U}$ dates is said to be concordant; if they are not, the dates are discordant. Concordant dates represent the age of the mineral with the following assumptions:

1- the mineral has behaved as a closed system throughout its history. 2- correct values are used for the initial lead isotope ratio,

3- the decay constants are known accurately,

4- the isotopic composition of $U$ is normal and has not been modified by isotope fractionation, 5- analytical results are accurate and free of systematic errors. For every time point on concordia, there is a unique ${ }^{207} \mathrm{~Pb} / 206 \mathrm{~Pb}$ ratio, and this varies from about 0.45 at $4 \mathrm{Ga}$ to 0.04607 for the present. Ages calculated using only this ratio are referred to ${ }^{207} \mathrm{~Pb} / 206 \mathrm{~Pb}$ ages.

Discordancy may result from loss or gain of $\mathrm{Pb}$ or $\mathrm{U}$. Several lead-loss models have been proposed to interpret discordant zircons. However, Krogh 
(1982) noted that the exact cause of discordia lines is largely unknown and introduced two imperisnt techniques in an attempt to eliminate rather than explain discordances. These are the air-abrasion technique and separation of the least paramagnetic grains. Both techniques are designed to eliminate from the sample the most damaged zircon fraction, that is most subject to lead loss. According to Krogh, discordancy in abraded zircon populations is of two general types:

1) Collnear discordia: The abraded samples yield data that move toward concordia along a line defined by the more discordant points. This results in a linear array on the concordia diagram. In the simplest interpretation, the upper intersection of this line with concordia represents the age of zircon formation, whereas the lower intercept represents the time of Pb loss or $U$ gain. Lead can be lost from the system by either continuous diffusion (Tilton, 1960), or by loss of water together with accumulated Pb contained in metamict zircons (dilatancy), the result of uplift and decrease in pressure (Goldich and Mudrey, 1972).

2) Multiple age population: Inheritance can result either (1) from the mixture of magmatic zircon with xenocrystic zircon from the source region of the magma or (2) solid state metamorphic growth of zircon under amphibolite or graralite facies conditions, around pre-existing crystals (Krogh and Davies, 1973; Parrish and Roddick, 1985). Mixing by any process of concordant grains with two different ages results in a linear array of data points that when extrapolated meets concordia at lower and upper intersections representing the two periods of zircon growth. As a measure of 
the goodness of fit of regression lines fitted to these arrays, the mean square of weighted deviates (MSWD) is employed (Ludwig, 1980). Abrasion allows the true ages of the two-component mixture to be determined only to the extent that discordance for $\mathrm{Pb}$ loss can be eliminated. Krogh also indicated that the degree of discordance can vary between grains in a single cogenetic fraction. Grains with their surfaces removed and the least paramagnetic grains provide the most concordant data.

\subsubsection{Analytical wethods}

$\mathrm{U} \cdot \mathrm{Pb}$ analyses of zircons from the study area were made at the geochronology laboratory of the Geological Survey of Canada. Details of the analytical procedure are given in Appendix 4.1. Heavy mineral concentrates were obtained using a heavy liquid (methylene iodide with 3.325 density at room temperature) and run through the Frantz magnetic separator at $1.0 \mathrm{amp}$. with a forward slope of $25^{\circ}$ and side tilt of $15^{\circ}$. The non-magnetic fraction was run through the separator repeatedly until most magnetic grains were removed by progressively increasing the amperage. The zircon concentrate was then split into different size fractions $(-149,+149$ to $-105,+105$ to -74 . +74 to -62 , and +62 ) with nylon sieves. The final zircon concentrate for analysis was obtained by hand picking. An air abrasion technique was used to remove the outer parts of the zircon in order to reduce the degree of discordancy (Krogh, 1982). For extraction of $\mathrm{U}$ and $\mathrm{Pb}$, the chemical procedure developed at the gechronology laboratory of the Geological Survey of Canada (Parrish et al., 1987) was used. 


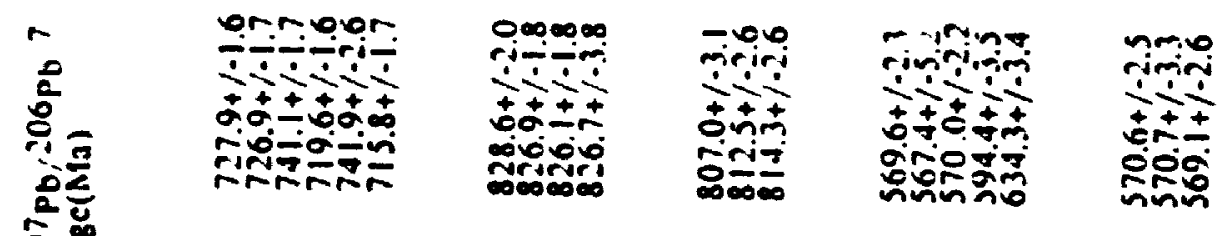

\%
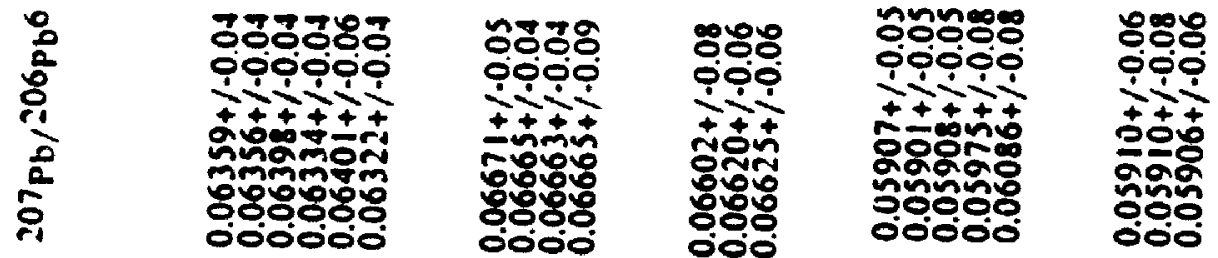

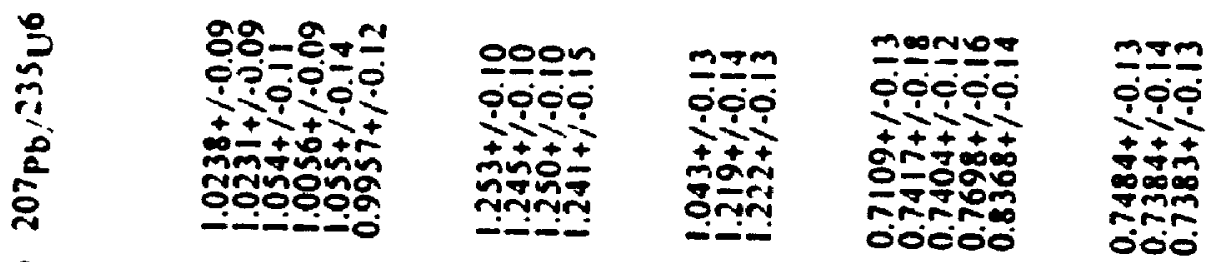

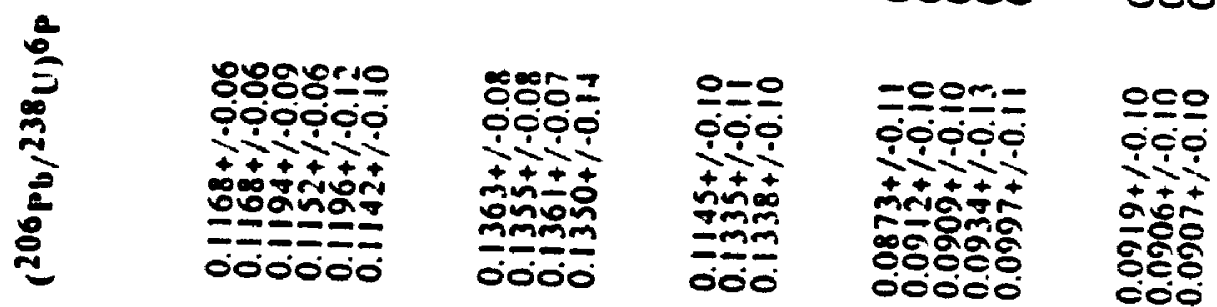
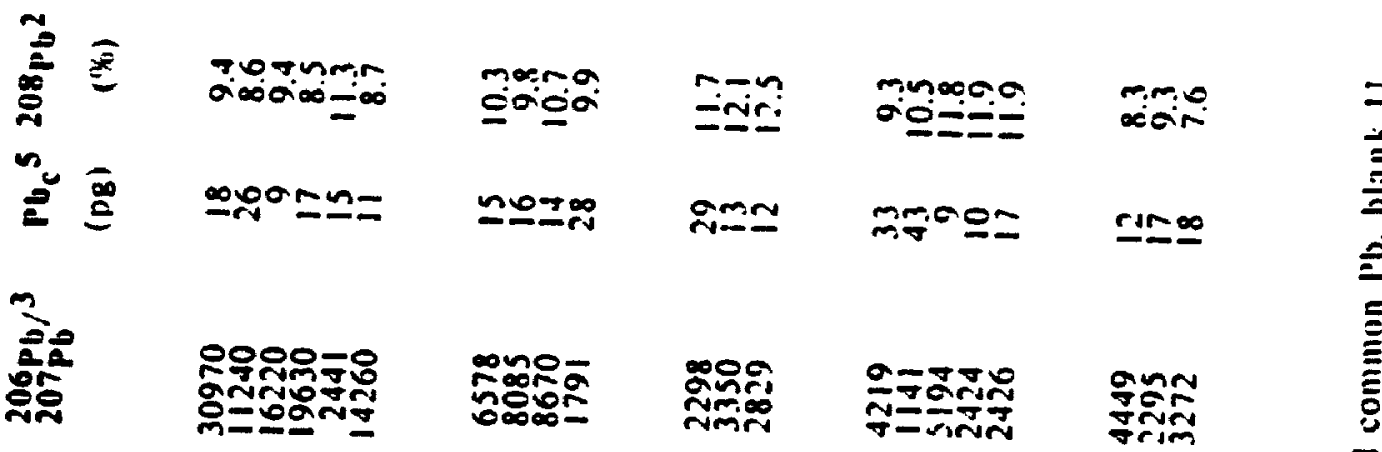

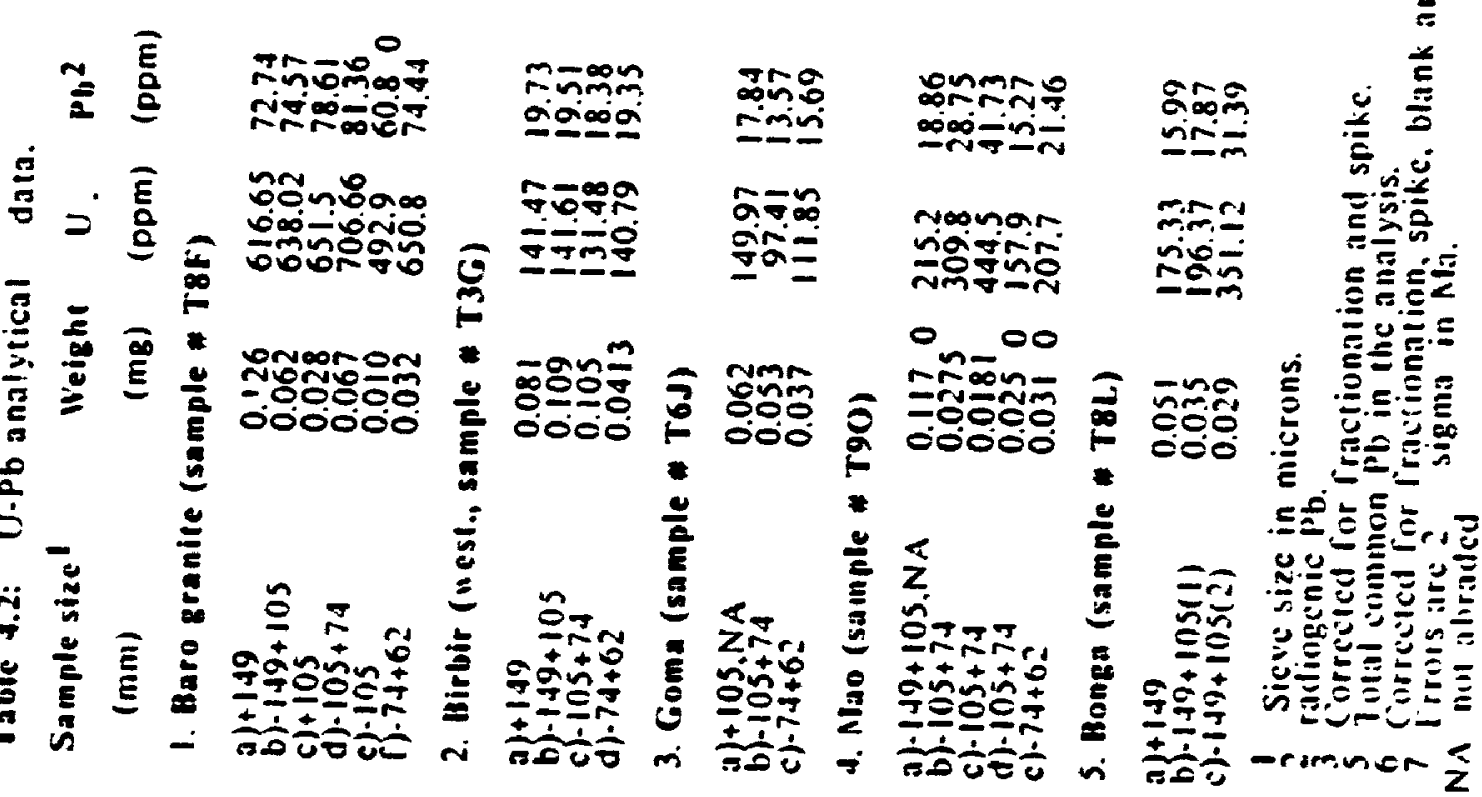




\subsubsection{Pre- and/or sya-kinematic Intrualive rocks}

Zircons from the Birbir quartz diorite complex (mqd) and Goma granodiorite pluton (mgd) broadly display similar morphological characteristics. The zircons are euhedral to subhedral, pris.adtic, mostly clear to partly turbid, and show multiple growth zoning under transmitted and geflected light. The zoning suggests that these zireons have a primary igneous origin. Some fractions contain distinctly turbid, flat, subequant grains, that may represent zircons strained by shearing: these zircons were not anslyzed.

A nearly-concordant upper intercept of $828+9 /-2$ Ma was obtained from four abraded size fractions extracted from a prototomylonitic quartz diorite of the Birbir complex (sample * T3G, Fig. 4.1; see Figs. 2.2 and 2.3 for sample localities). The small degree of uncertainty attached to the upper intercept unambiguously indicates the emplacement age of the Birbir quartz diorite complex. Three data points ( 2 abraded and 1 not abraded) from the Goma granodiorite pluton yield an age of $814+2 /-2 \mathrm{Ma}$ (sample * T6J; Fig. 4.2) which is also interpreted as the intrusion age. The data point for the unabraded $+105 \mathrm{~mm}$ size fraction plots below concordia and clearly shows the importance of abrasion in producing more concordant results from zircons.

\subsubsection{Sya-kinematic Baro leucogranite}

Highly-deformed leucogranites characterize the Baro Domain. In both reflected and transmitted light, the zircons from one of these granite sheets, the Baro leucogranite (sample * T8F; sample locality shown in Fig. 2.2 ), are mainly subhedral and tabular to ellipsoidal in shape. The least 


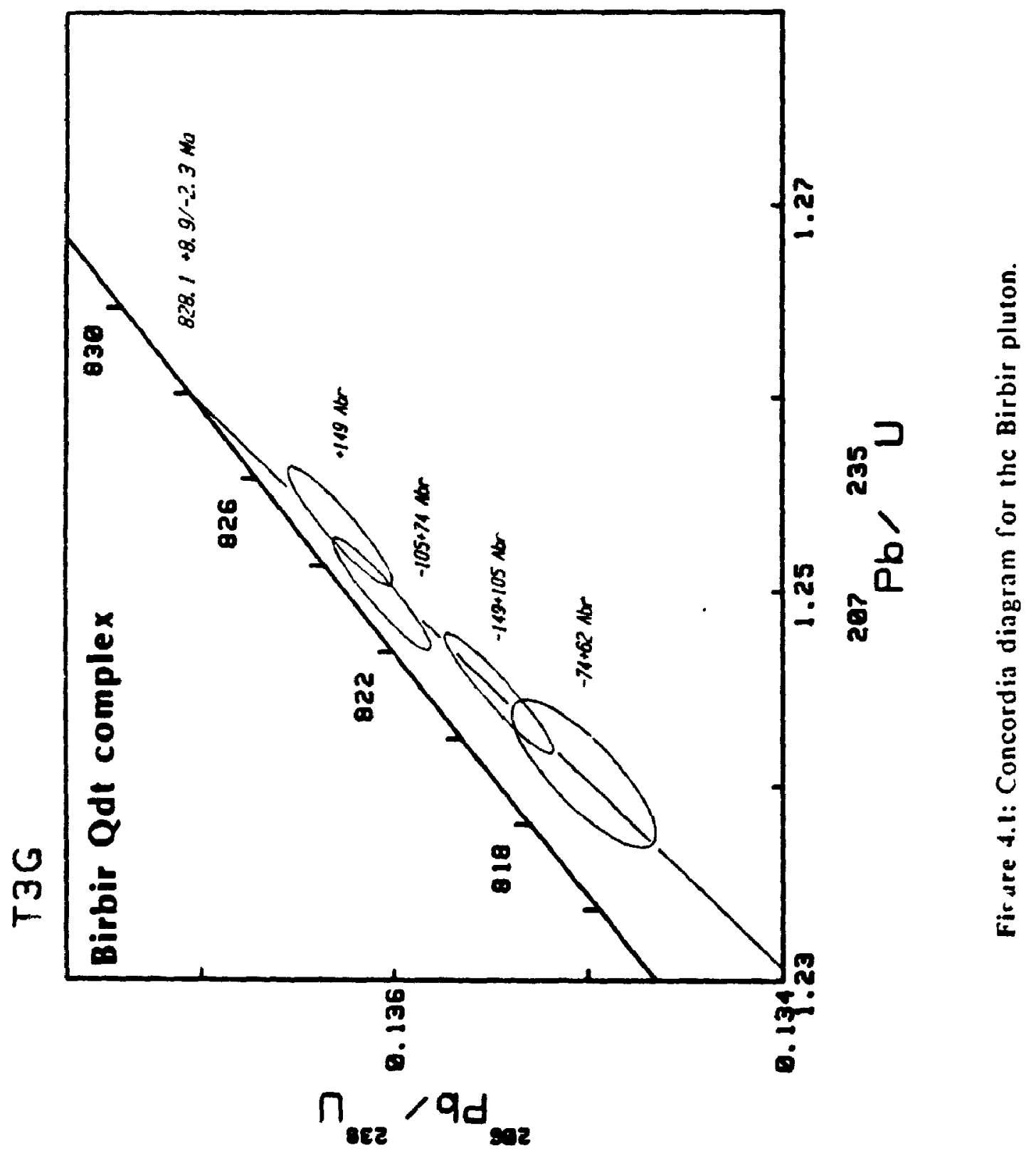




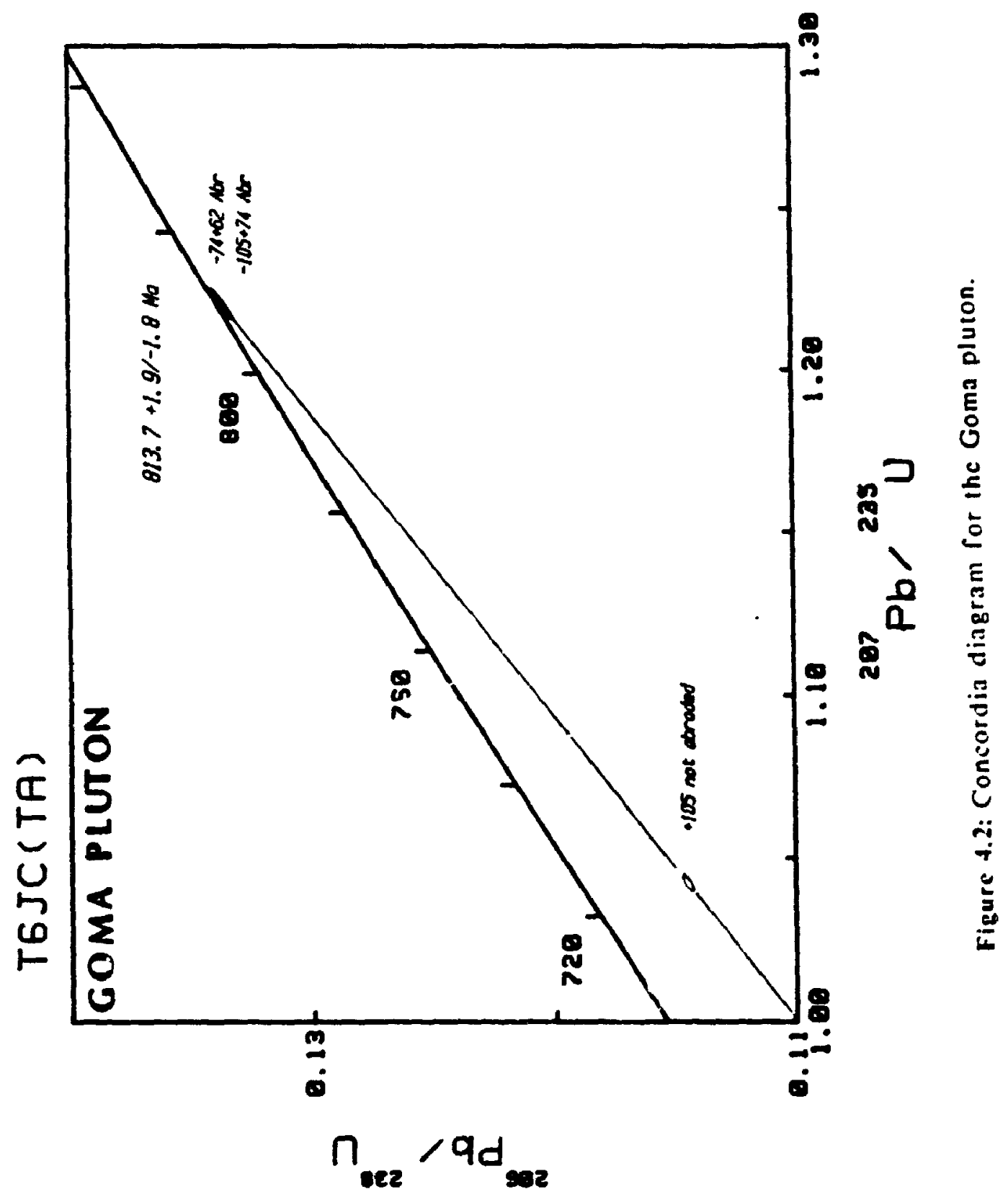


damaged crystals in six fractions were seiected, and all fractions were abraded.

Data are shown in Fig. 4.3. They define a linear array below concordia, with an upper intercept of $783+19 /-14$, a lower intercept of $582+29 /-33$ and an MSWD of 1.59. The large uncertainty attached to both intercept ages reflect the restricted spread of data and the long extrapolations to concordia. The dates so obtained could be a result of different degrees of Pb loss within a cogenetic zircon population or alternatively reflect a mix of isotopic ratios of zircons of different generations. An interpretation of the discordant dates thus required further investigation, particularly as to the internal morphology of the zircons.

Photomicrographs with a scanning electron microscope (SEM) of HF-etched zircons from T8F show a complex internal morphology. Plates $3.1 \mathrm{~A}, \mathrm{~B}$ and $\mathrm{C}$ show that these zircons have readily recognizable euhedral zoned cores rimmed by a clear, unzoned overgrowth. Such a pattern is typical of metamorphic overgrowth on igneous zircon. Some contain small rounded inclusions of an earlier generation of zircon within the zoned crystals. In addition the igneous zircons contain hematite, feldspar(?), and fluid inclusions.

The data are typical of the multiple age population of Krogh (1982) that represent mixtures of magmatic zircon with metamorphic overgrowth. The upper intersection age is interpreted as a first approximation to the age of the magmatic zircons. This age is thus attributed to igneous emplacement near the time of anatexis under peak metamorphic conditions in the Baro Domain (sec Chapters 2 and 3). It coincides with metamorphic age of similar 


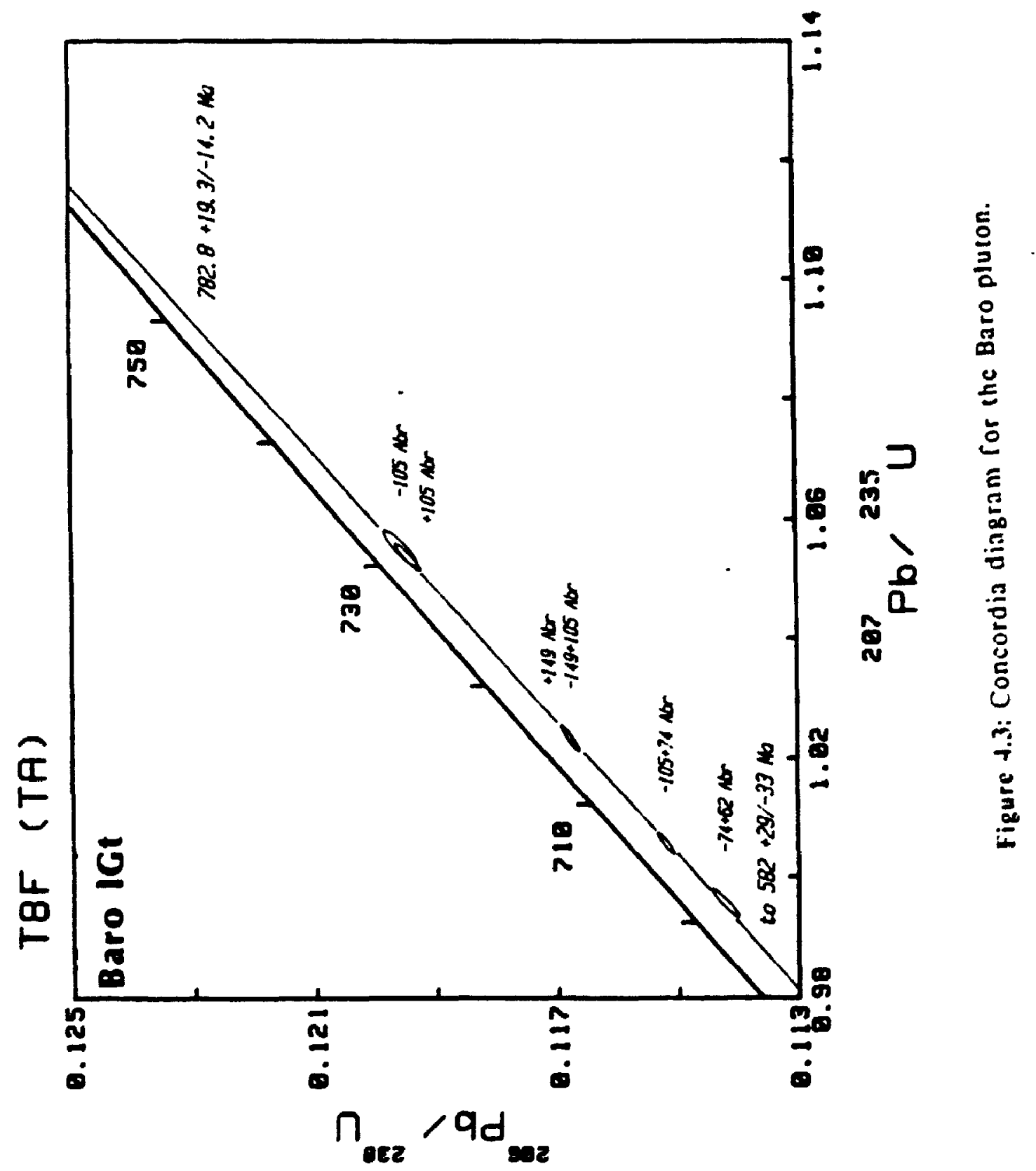


Plate 4.I: Scauning electron photomicrographs of HF-etched zircon grain mounts from the Baro leucogranite (Plates 4.1: A,B,C) and the Mao pluton (Plates 4.1 D, E, F). Plates are described in text. 

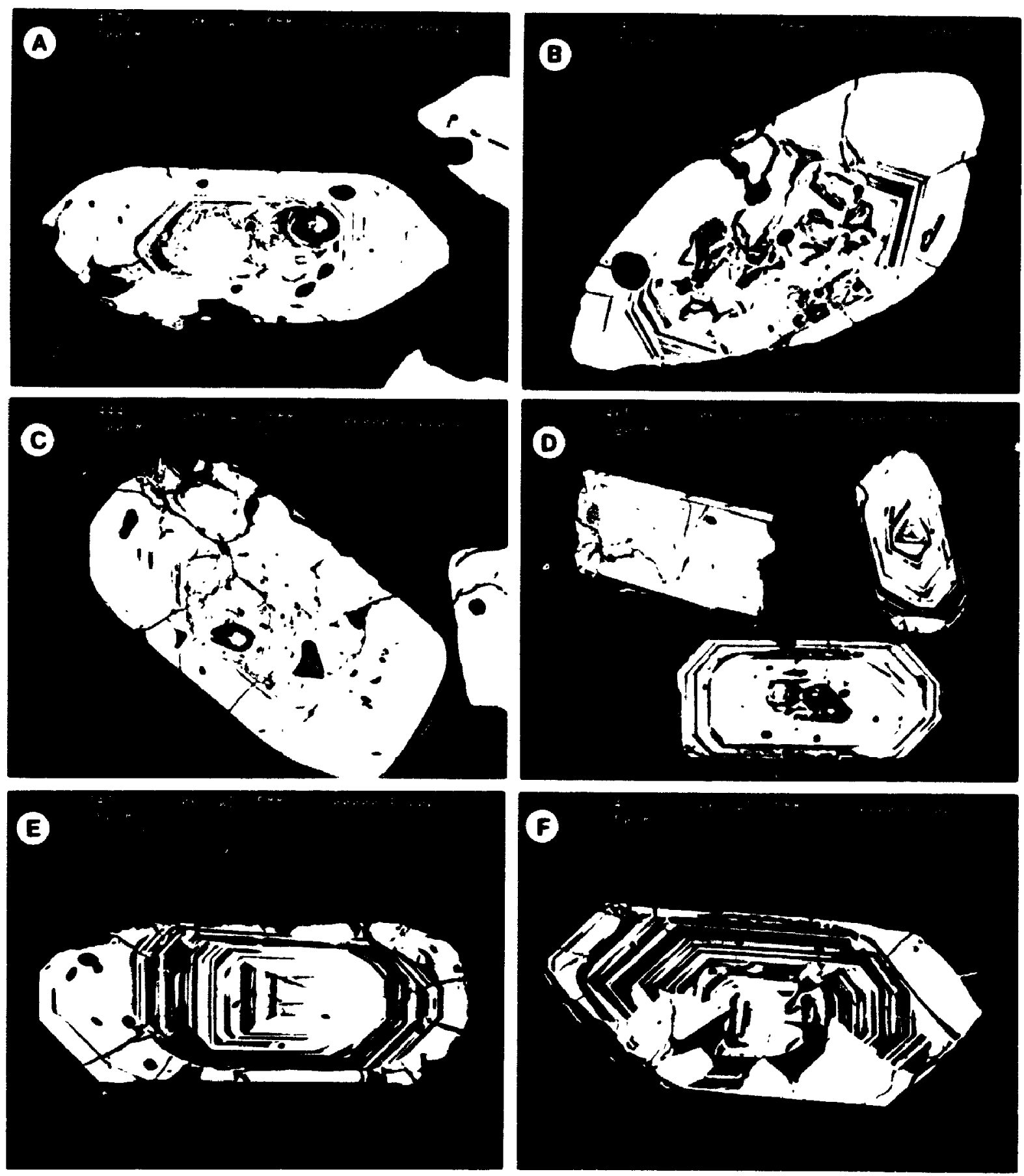
rocks from W Kenya (Suwa, 1979).

The lower intersection is inferred as a time of high-temperature metamorphic overgrowth of zircon at $580+/-30 \mathrm{Ma}$. There is also independent evidence from high-grade rocks in NW Kenye, that are similar to rocks found in the Baro Domain that is suggestive of metamorphic activity at $584 \mathrm{Ma}$ (Ries et al., unpublished) Thus, the zircon overgrowths are evidence of upper amphibolite facies metamorphism at ca. $580 \mathrm{Ma}$ ago in the Baro Domain.

\subsubsection{Late- to post-kinematic plutons}

$\mathrm{U}-\mathrm{Pb}$ analyses of four zircon fractions from sample * T9O of the Mao pluton yielded discordant dates when plotted on a concordia diagram (Fig. 4.4). The pluton is discordant with respect to the foliation and layering in the country rocks. The sample comes from the eastern margin of the pluton and shows foliation and shear bands, superimposed on an igneous texture. The zircons extracted from the sample are predominantly clear and prismatic but some are tabular and of turbid appearance. Four size fractions of the former were analyzed, and fit a chord with an MSWD $=4.22$, with an upper intercept of $772+70 /-63 \mathrm{Ma}$ and a lower intercept at $541+10 /-16 \mathrm{Ma}$.

Plates 4.1 D, E and F show SEM photomicrographs of zircons from sample * T90. The lowermost zircon grains shown in Plate 4.1D consists of a core with dark, possibly hematite inclusions, mantled by well-developed igneous zonation while those shown in $4.1 \mathrm{E}$ and $\mathrm{F}$ are free of cores and display welldeveloped igncous zoning. A few contain re-entrants filled wi:h homogencous zircon that may have resulted from microf racturing and filling of indentations, metamorphic regrowth or resorption possibly at the time of shearing. 


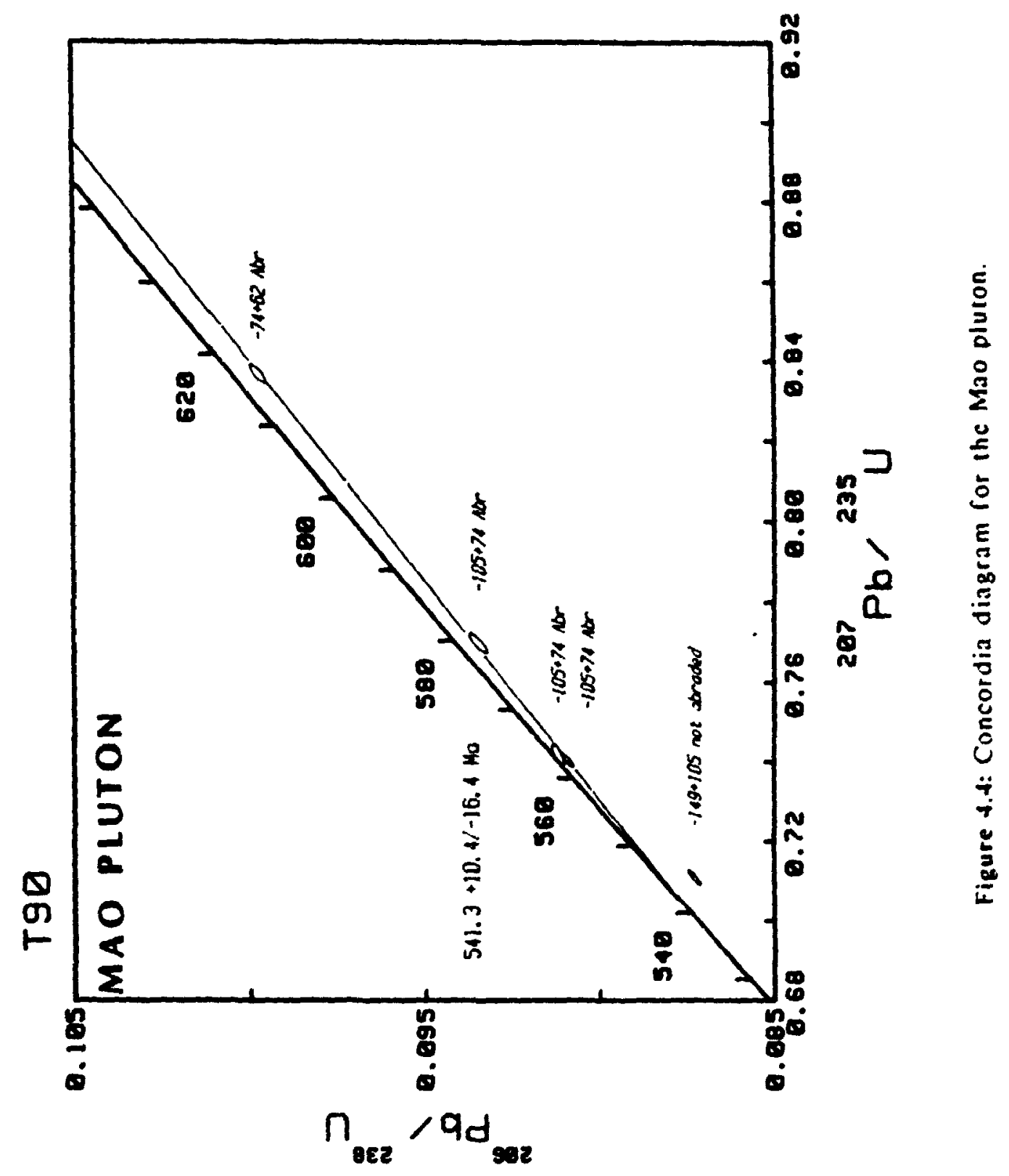


No simple interpretation of discordia is possible here for this complex internal morphology. The apparently inherited cores shown in Plate 4.1 D and the data points shown in Fig. 4.4 that trend away from concordia appear to result primarily from a mixture of two generations of zircon. Data points of fractions that plot close to the lower intersection are considered relatively free of inherited zircon. Thus, the convergence of data from abraded zircons on a lower intercept of about $550+/-10 \mathrm{Ma}$ is considered as the best estimate for the age of igneous zircon crystallization, and therefore the age of intrusion. The upper intersection has a large uncertainty but may be tentatively interpreted as the age of the inherited cores. The infilled re-entrants that characterize some of the grains may have contributed to the large uncertainty.

It is interesting to note that the upper intersection overlaps within analytical uncertainty the age of the pre- and/or syn-kinematic intrusive rocks in which the Mao pluton was intruded. It is interpreted as the age of the zircon generated at the same time as the Baro leucogranites.

Analyses of three zircon fractions from quartz monzonite of the Bonga pluton define a nearly concordant data set at $571+11 /-3 \mathrm{Ma}$ (Fig. 4.5). The pluton is discordant with respect to the regional fabric; it straddles the boundary between the Birbir and Baro domains. The sample, massive and containing K-feldspar megacrysts, was obtained from the quartz monzonite core of the pluton which is cut by granite that forms the margin of the pluton. The analyzed zircons are all clear, prismatic and show typical 


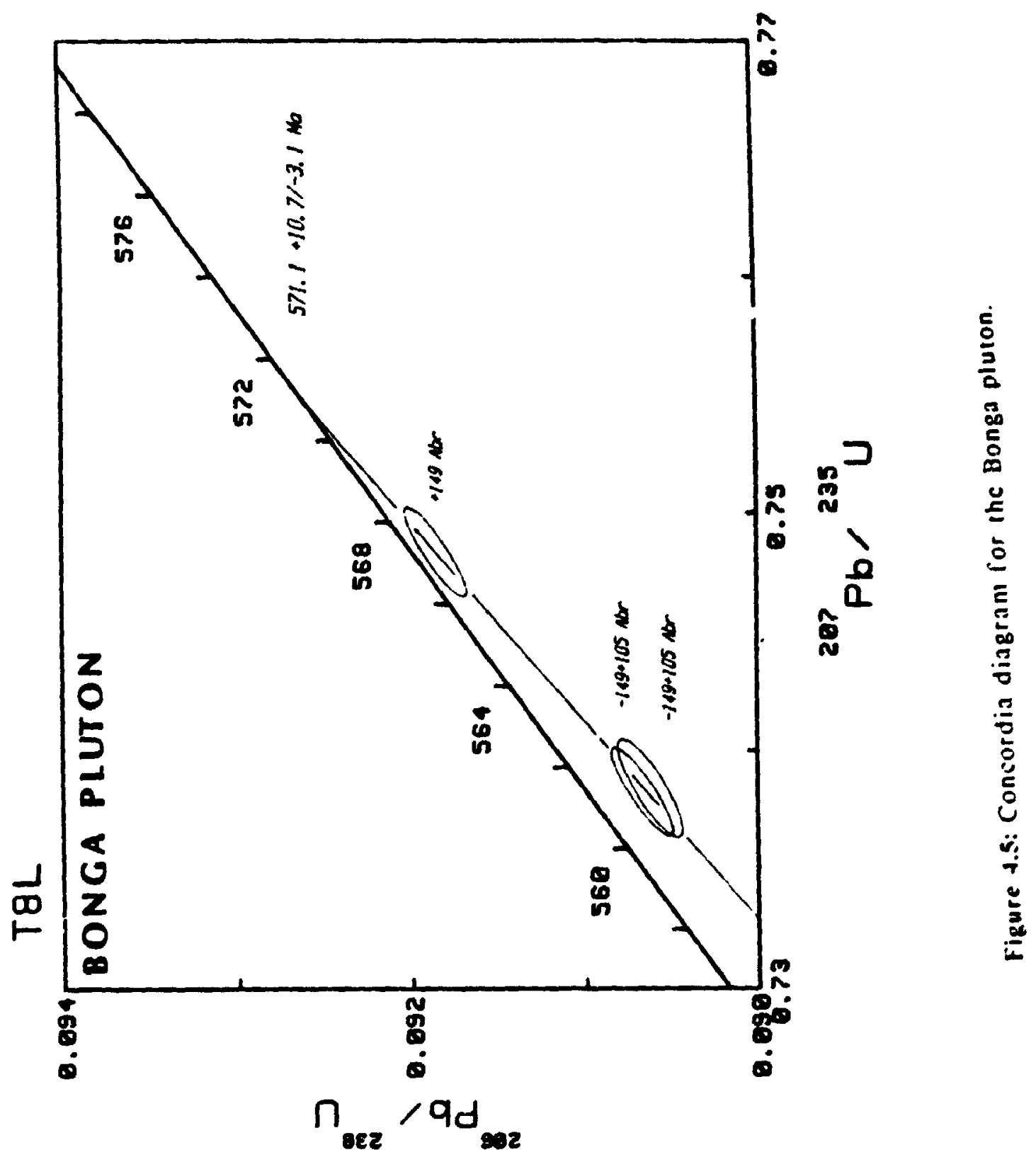


igneous growth zonation under transmitted light. The $571+11 /-3 \mathrm{Ma}$ date is thus interpreted as representing the time of emplacement of the quartz monzonite of the Bonga pluton. 


\subsection{Rb-Sr SYSTEMATICS AND THE ISOCHRON DIAGRAM}

The number of ${ }^{87} \mathrm{Sr}$ daughter atoms produced by decay of ${ }^{87} \mathrm{Rb}$ in a rock or mineral since time of formation, $t$ years ago, is given by an equation similar to those already used to treat the decay of $U$ :

$$
{ }^{87} \mathrm{Sr}_{\mathrm{T}}={ }^{87} \mathrm{Sr}_{\mathrm{i}}+{ }^{87} \mathrm{Rb}\left(\mathrm{e}^{\lambda_{\mathrm{t}}}-1\right)
$$

where $\left({ }^{87} \mathrm{Sr}\right)_{\mathrm{T}}$ is the total number of atoms at the present time; $\left({ }^{87} \mathrm{Sr}\right)_{\mathrm{i}}$ is the number of atoms of this isotope that were initially incorporated into the system at the time of its formation: ${ }^{87} \mathrm{Rb}$ is the number of atoms of this isotope at the present time; $\lambda$ is the decay constant of ${ }^{87} \mathrm{Rb}$; is the time elapsed since the time of formation of the system. Rather than use the absolute number of atoms of a given nuclide, ratios are used by dividing through by ${ }^{86} \mathrm{Sr}$, and the equation is rewritten as:

$$
\left({ }^{87} \mathrm{Sr} /{ }^{86} \mathrm{Sr}\right)_{\mathrm{T}}=\left({ }^{87} \mathrm{Sr} /{ }^{86} \mathrm{Sr}\right)_{\mathrm{i}}+{ }^{87} \mathrm{Rb} /{ }^{86} \mathrm{Sr}\left(\mathrm{e}^{\lambda_{\mathrm{t}}} \cdot 1\right)
$$

This equation has two unknowns: the age $t$ and the initial ratio. $\left({ }^{87} \mathrm{Sr} /{ }^{86} \mathrm{Sr}\right)_{\mathrm{j}}$. The ${ }^{87} \mathrm{Sr} /{ }^{86} \mathrm{Sr}$ of a rock sample increases with time, the rate of increase depending on the $\mathrm{R} b / \mathrm{Sr}$ ratio of the sample. Similarly the initial ratio of a suite of rocks depends on the $\mathrm{Rb} / \mathrm{Sr}$ ratio of the source of those rocks. In order to determine the age of an igneous body, the present day $\left({ }^{87} \mathrm{Sr} /{ }^{86} \mathrm{Sr}\right) \mathrm{T}$ and ${ }^{87} \mathrm{Rb} /{ }^{86} \mathrm{Sr}$ ratios of a suite of samples are measured. All rock specimens belonging to a comagmatic suite will plot as points on a straight line in coordinates of ${ }^{87} \mathrm{Rb} /{ }^{86} \mathrm{Sr}$ and ${ }^{87} \mathrm{Sr} /{ }^{86} \mathrm{Sr}$. This line is called an isochron. Its slope is proportional to $t$, and the intercept defines $\left({ }^{87} \mathrm{Sr} /{ }^{86} \mathrm{Sr}\right)_{j}$. A suite of co-magmatic rocks of age $t$ will define an isochron only when each member of that suite had the same 
$\left({ }^{87} \mathrm{Sr} /{ }^{86} \mathrm{Sr}\right)_{\mathrm{i}}$ and the rocks have behaved as a closed system since crystallization.

Dating of metamorphosed igneous rocks is based on the assumption that a whole-rock domain of a certain size remains as an effectively closed system during a metamorphic event. This is achieved by collecting samples exhibiting a range of $\mathrm{Rb} / \mathrm{Sr}$ ratios, so that the resultant isochron may be well defined. If a data point does not fit the isochron within random analytical errors, then the coordinates of the tata point either have systematic analytical error or the sample does not satisfy the assumptions inherent in the isochron method (Faure, 1986).

Whole-rock Rb-Sr dating of granitoid rocks commonly yiclds younger ages than the U-Pb ages from the same rock (Kennan and Murphy, 1987). Bell and Blenkinsop (1978) and Field and Raheim (1979) have shown that the wholerock systems can be completely re-set by metamorphic activity. It is also possible that an apparent isochron age produced by incomplete re-setting may yield an age that may have little meaning and be unrelated to any geological event. In other cases, more than one isochron date from the same pluton could result from heterogeneous deformation and recrystallization.

The Rb-Sr isotcpic data for five plutonic units are listed in Table 4.3. In addition, results from various regression analyses using different sample groups are summarized in Table 4.4.

\subsubsection{Sampline and sanalytical methods}

Samples were collected from a total of nine plutons. Between 8 and 14 
samples per pluton were selected representing the compositional and textural variability of the plutons. Samples that showed visible alteration. fractures, veins and xenoliths were avoided. The seographical spread of the samples typically extends over several kilometres (Fis 2.3). Two to $3 \mathrm{~kg}$ samples were considered adequate for Rb-Sr geochronological studies. Rb and Sr concentrations were determined by $X$-ray fluorescence spectrometry on 10 $15 \mathrm{gm}$ pellets, using G-2 as the reference standard. Mass absorption coefficients were determined using the method of Norrish and Chappell (1967). The estimated uncertainties are $+/-2 \%$ for Rb and Sr abundance, and $1 \%$ for the $\mathrm{Rb} / \mathrm{Sr}$ ratios.

Standard ion exchange procedures were employed in $\mathrm{Rb}-\mathrm{Sr}$ separation and collection (see Appendix 5). Isotopic analyses were made on a Finnigan-MAT 261 multicullector, solid source mass spectrometer operated in the static mode (see Bell et al., 1987).

Errors are quoted throughout at the 1 sigma level and the decay constant used in the age calculations is the value recomm:nded by the IUGS subcommision for geoct.ronology (Steiger and Jager, 1977). Regression lines were calculated using a least squares method based on that of York (1969). Where the mean square of weighted deviates (MSWD) exceeds 2 as the limiting or critical value, the scatter of data about the line can not be accounted for entirely by experimental error. If a line is fitted through such data it is termed a "scatterchron", and the valtus quoted for age and $\left({ }^{87} \mathrm{Sr} /{ }^{86} \mathrm{Sr}\right)$ i should be viewed with caution. 
Table 4.3: Rb-Sr whole-rock and mineral analytical data.

\begin{tabular}{|c|c|c|c|c|c|}
\hline Sampie & $\begin{array}{l}R b^{\prime} \\
(p p m)\end{array}$ & $\begin{array}{r}S r^{\prime} \\
(p p m)\end{array}$ & $R \mathbf{R} / \mathrm{S}$ & $\begin{array}{l}{ }^{87} \mathrm{Rb} / \\
\text { c) }\end{array}$ & ${ }^{87} \mathrm{Sr} /{ }^{86}$ \\
\hline Birbir & \multicolumn{5}{|c|}{ (west) - whole-rock } \\
\hline T5G & 66 & 609 & 0.108 & 0.311 & 0.70648 \\
\hline T9G & 57 & 564 & 0.101 & 0.290 & 0.70032 \\
\hline$\Gamma ! 2 G$ & 73 & 517 & 0.142 & 0.409 & 0.70728 \\
\hline T6G & 49 & 584 & 0.084 & 0.242 & 0.70608 \\
\hline $\mathrm{T} 7 \mathrm{G}$ & 49 & 650 & 0.076 & 0.219 & 0.70588 \\
\hline$T I \| G$ & 30 & 891 & 0.034 & 0.097 & 0.70454 \\
\hline$T 4 G$ & 69 & 569 & 0.124 & 0.357 & 0.70694 \\
\hline
\end{tabular}

Birbir - Biolite

$\begin{array}{llllll}\text { TSG } & 320.8 & 4.4 & 72.262 & 238.6 & 2.15168 \\ \text { TiH } & 289.5 & 4.7 & 62.128 & 216.9 & 2.82419 \\ \text { T8I } & 233.4 & 4.9 & 47.356 & 15279 & 1.88806\end{array}$

Birbir (central) - whole-rock

$\begin{array}{llllll}\text { TIH } & 63 & 429 & 0.148 & 0.428 & 0.70742 \\ \text { T5H } & 49 & 495 & 0.099 & 0.287 & 0.70671 \\ \text { T8H } & 42 & 443 & 0.095 & 0.275 & 0.70646 \\ \text { T1OH } & 59 & 462 & 0.127 & 0.348 & 0.70725 \\ \text { T2H } & 62 & 511 & 0.122 & 0.353 & 0.70728 \\ \text { T?H } & 56 & 499 & 0.112 & 0.324 & 0.70723 \\ \text { THH } & 55 & 498 & 0.109 & 0.316 & 0.70706\end{array}$

Goma - whole-roch

$\begin{array}{llllll}\text { THJ } & 64 & 281 & 0.229 & 0.662 & 0.70989 \\ \text { TSJ } & 71 & 296 & 0.241 & 0.694 & 0.71027 \\ \text { T6J } & 52 & 342 & 0.151 & 0.436 & 0.70753 \\ \text { T21J } & 68 & 304 & 0.222 & 0.643 & 0.70946 \\ \text { T23J } & 71 & 283 & 0.251 & 0.725 & 0.71070 \\ \text { T34J } & 59 & 325 & 0.181 & 0.524 & 0.70838 \\ \text { TIJ } & 67 & 311 & 0.214 & 0.618 & 0.70955 \\ \text { T2J } & 53 & 321 & 0.164 & 0.475 & 0.70857 \\ \text { TiJ } & 56 & 341 & 0.164 & 0.474 & 0.70834 \\ \text { TSJ } & 54 & 358 & 0.151 & 0.436 & 0.70790\end{array}$

1 Rb and Sr abundances for the whole-rock samples weredetermined b! VRF. and for biotitc b! isotope dilution analysis.

$=$ Measured ${ }^{8-}$ Sr ${ }^{86} \mathrm{Sr}$ ratho is normalized to a value of ${ }^{86} \mathrm{Sr}^{88} \mathrm{Sr}=0.1194$ 
Table 4.3 (continued)

Sanple $\quad \underset{(\mathrm{ppm})}{\mathrm{Rb}} \quad \underset{(\mathrm{ppm})}{\mathbf{S}^{1}}$ (ppm) (ppm)

Mao - whole-rock

T7O 178

T9O $\quad 176$

T110 189

T5O $\quad 176$

T6O 185
229

238

215

221

224
$\mathrm{Rb} / \mathrm{Sr} \quad{ }^{87} \mathrm{Rb} /{ }^{86} \mathrm{Sr}$ (atomic) (atomic)
${ }^{87} \mathrm{Sr} /{ }^{86} \mathrm{Sr}$

0.72110

0.72057

0.72386

0.72181

0.72220

Bonga - whole-rock

$\begin{array}{llllll}\text { T6K } & 139 & 38 & 3.672 & 10.699 & 0.78540 \\ \text { T8K } & 111 & 36 & 3.066 & 8.912 & 0.77646 \\ \text { TI0K } & 117 & 45 & 2.598 & 7.554 & 0.76409 \\ \text { T11K } & 115 & 44 & 2.632 & 7.657 & 0.76574 \\ \text { T1K } & 111 & 61 & 1.827 & 5.303 & 0.74667 \\ \text { T4K } & 92 & 40 & 2.322 & 6.748 & 0.75652\end{array}$




\begin{tabular}{|c|c|c|c|c|}
\hline $\begin{array}{l}\text { Plucon/ } \\
\text { complex }\end{array}$ & Sample Nos. & Date ${ }^{1}$ & Intercept & MSWD \\
\hline \multirow[t]{4}{*}{ Goma } & $\begin{array}{l}\text { TJ:4,5,6,21 } \\
23,24,1,2,3,8 \\
(10 \text { pts. })\end{array}$ & $677+/-12$ & $\begin{array}{l}0.703576+1- \\
0.0001\end{array}$ & 20.6 \\
\hline & $\begin{array}{l}\text { TJ:6,24,1,21, } \\
4,5,23 \text { (7pts.) }\end{array}$ & $750+/-17$ & $\begin{array}{l}0.702813+1 \\
0.0001\end{array}$ & 3.6 \\
\hline & $\begin{array}{l}\text { TJ:6.24.1,4.5, } \\
23 \text { (6 pts.) }\end{array}$ & $\begin{array}{c}759+i-18 \\
.\end{array}$ & $\begin{array}{l}0.702773+1 \\
0.0001\end{array}$ & 1.3 \\
\hline & $\begin{array}{l}\text { TJ }: 8,3,1,4,5 \\
23(6 \mathrm{pts})\end{array}$ & $640+/-14$ & $\begin{array}{l}0.703948+/ / \\
0.0001\end{array}$ & 2.3 \\
\hline \multirow[t]{2}{*}{$\begin{array}{l}\text { Birhir } \\
\text { (west.) }\end{array}$} & $\begin{array}{l}\text { TG:5.9.12.6.7. } \\
11.4(7 \text { nts.) }\end{array}$ & $698+-67$ & $\begin{array}{l}0.703745+ \\
0.00003\end{array}$ & 17.3 \\
\hline & $\begin{array}{l}\text { TG:5.9.12.11. } \\
+(5 \text { pts.) }\end{array}$ & $632+-8$ & $\begin{array}{l}0.703675+\therefore \\
0.00003\end{array}$ & 2.2 \\
\hline \multirow[t]{2}{*}{$\begin{array}{l}\text { Birlier } \\
\text { (contral) }\end{array}$} & $\begin{array}{l}7113.5 .8 .10 .2 . \\
7.417 \text { pis.) }\end{array}$ & $510+,-18$ & $\begin{array}{l}0.703259+ \\
0.0001\end{array}$ & 37.7 \\
\hline & $\begin{array}{l}\text { TH.5.8.10.2. } \\
+15 \text { nts.) }\end{array}$ & $633+-31$ & $\begin{array}{l}0.704062+\cdot \\
0.0001\end{array}$ & 12.1 \\
\hline ?lao & $\begin{array}{l}10: 9.9 .11 .5 \\
615 \text { pts.) }\end{array}$ & $552+-41$ & $\begin{array}{l}0.703553+- \\
0.0014\end{array}$ & 1.3 \\
\hline Bonga & $\begin{array}{l}T K: 8.10 .11 .1 . \\
\text { t.6 } 16 \text { pts.) }\end{array}$ & $540+-10$ & $\begin{array}{l}0.705784+\therefore \\
0.001\end{array}$ & 7.2 \\
\hline
\end{tabular}




\subsubsection{Blrblr quartz diorite complex}

Seven samples from the western quartz diorite sheet (Fig. 2.2) yielded a scatterchron corresponding to a date of $698+/-67 \mathrm{Ma}$, an intercept of 0.70375 $+/-0.00003$, and MSWD $=17.3$. The MSWD is significantly reduced when two data points are omitted from the calculation. A five-point isochron yields a date of $632+/-8 \mathrm{Ma}$, an intercept of $0.70368+/-0.00003$ and an MSWD - 2.2 (Fig. 4.6b). The two samples excluded from the calculation have a high ${ }^{87} \mathrm{Sr} /{ }^{86} \mathrm{Sr}$ present day ratio, exhibit relatively high mylonitic strain and contain a higher proportion of granular aggregates of epidote and apatite than the other five samples. Epidote, rich in $\mathrm{Ca}$, preferentially incorporates radiogenic Sr (Steiger and Wasserburg, 1969).

The central quartz diorite sheet yields a seven point scatterchron with a slope of $510+/-18 \mathrm{Ma}$, an intercept of $0.70326+/-0.0001$, and an MSWD=37. When two samples were excluded from the regression, a five point scatterchron yields a slope of $633+/-31 \mathrm{Ma}$, an intercept at $0.70406+/-0.0001$, and a substantially reduced MSWD of 12 . The latter date from the central quartz diorite sheet overlaps, within analytical error, that obtained from the western quartz diorite sheet. The dates are much lower than the U-Pb zircon upper intersection age of $828 \mathrm{Ma}$ from the Birbir quartz diorite, considered to be the age of intrusion. The significantly different Rb-Sr date is attributed to subsequent resetting of the $\mathbf{R b}-\mathbf{S r}$ system. The reset isochron dates of ca. $633 \mathrm{Ma}$ are interpreted here as the time when the isotopic system re-enuilibrated, perhaps reflecting a major deformation and recrystallization event that affected the Birbir quartz diorite complex 


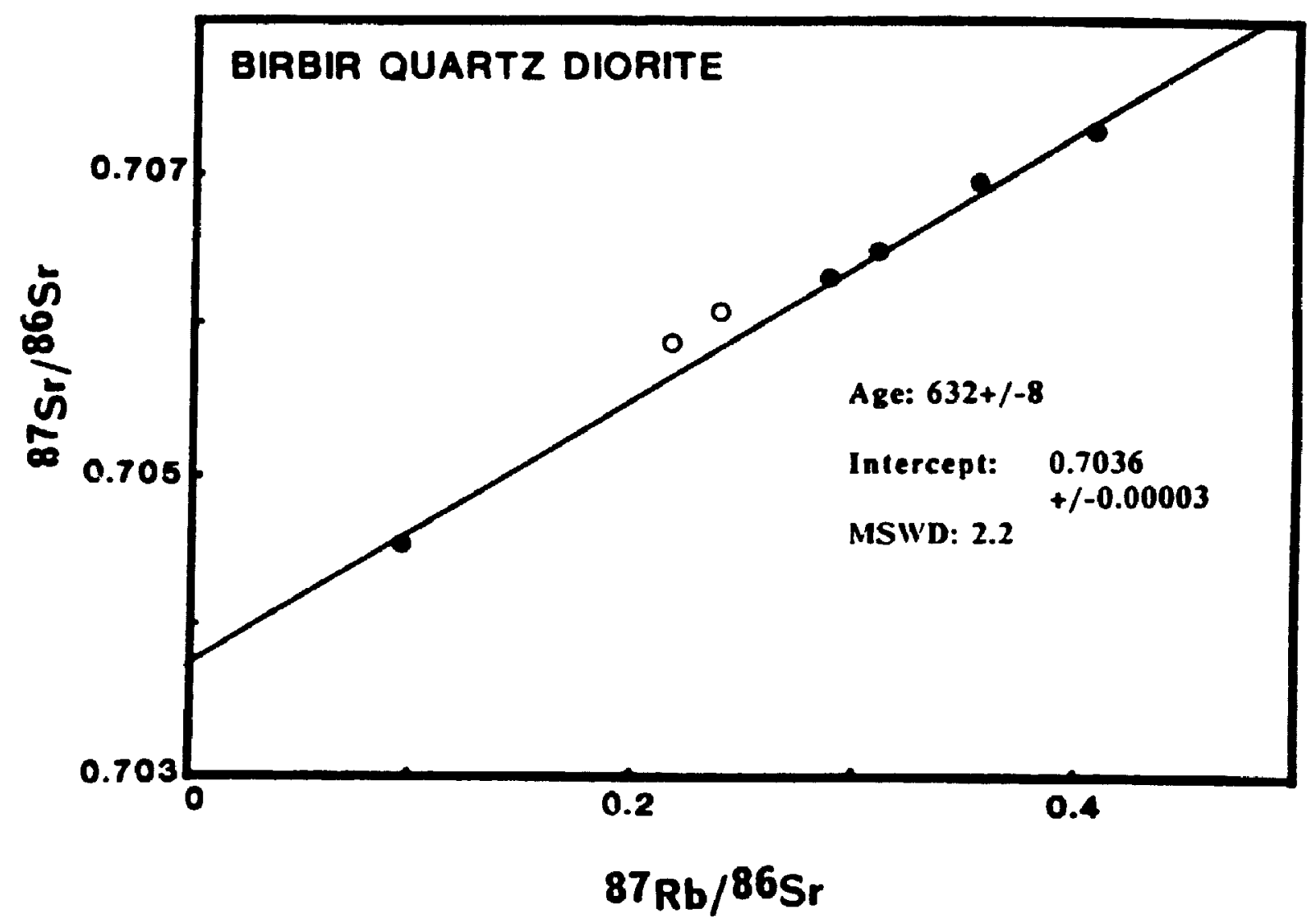

Figure 4.6: Isochron plot for Birbir quartz diorite. Open circles represent data points omitted from calculation. 
during major transcurrent movement along the Birbir Shear Zone.

\subsubsection{Goma granodlorite pluton}

Data from ten samples yield a scatterchron corresponding to a date of $677+/-12 \mathrm{Ma}$, an initial ratio of $0.70358+/-0.0001$, and an MSWD-20.6. The points do not fit the isochron within analytical errors, thus no simple interpretation is possible. The data points, however, can be used to define two different regression lines. The two groups of samples are not geographically related; they have four common data points: samples TIJ, T4J, TSJ and T23J, all of which display subhedral-granular texture and broadly can be classified as protomylonites.

The group that yields the older isochron date (Table 4.4), consists of the four common points together with samples T6J. T21J and T24J, that are protomylonitic. The seven data points yield a date of $750+/-17 \mathrm{Ma}$ with an intercept at $0.70281+/-0.0001$, and an MSWD=3.6. If sample T21J, which shows significant chloritization of biotite and sericitization of feldspar, is excluded then the remaining six points yield a figure of $759+/-18$, an initial ${ }^{87} \mathrm{Sr} /{ }^{86} \mathrm{Sr}$ ratio of $0.70277+/-0.0001$ and an MSWD=1.3 (Fig. 4.7a).

Grouping samples T3J and T8J, both of which are more highly deformed than the others, with the four common points however yields a younger isochron of $640+/-14 \mathrm{Ma}$ and an intercept of $0.70395+/-0.0001$ with an MSWD=2.3 (Fig. 4.7b).

The Rb-Sr isochron dates point to events significantly younger than the $814+2 /-2$ Ma event indicated by the concordant upper intercept $U-P b$ circon 

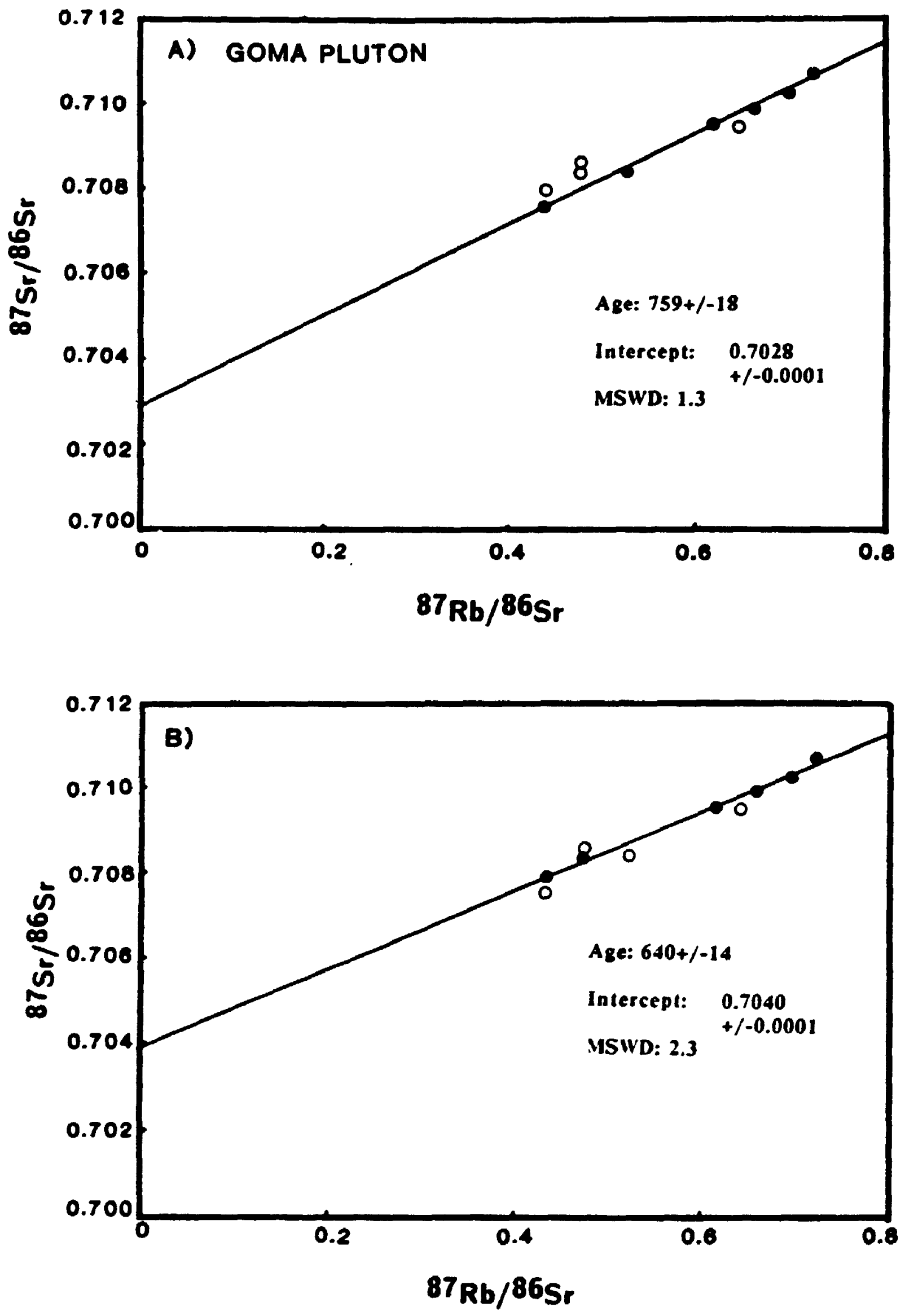

Figure 4.7 a,b: Two re-set isochron plots from the Goma pluton. Open circles represent data points omitted from calculation. 
age, which almost certainly represents an emplacement age. The two different Rb-Sr dates from the Goma pluton clearly reflect resetting of the isotope system. The two Rb-Sr isochrons may be related to variable degrees of deformation and recrystallization.

The $759+/-18 \mathrm{Ma}$ isochron date has a low MSWD of 1.3 and is based on data obtained from the protomylonite, those least affected by mylonitization associated with the Birbir Shear Zone. Isotopic re-equilibration is thought to represent an early thermal event within the Birbir Domain. Correlation of the Rb-Sr whole-rock date with a significant thermal event is supported by the zircon age of $783+19 /-14 \mathrm{Ma}$ from a presumed, syn-metamorphic leucogranite within the Baro Domain.

The second set of data points yields a significantly different slope and intercept, but the slope of the isochron is controlled mainly by the two data points from the mylonitic samples. Although the 640 Ma date may be spurious, it does coincide with the dates recorded by the more highly mylonitized samples from the Birbir quartz diorite (Fig. 4.10). 
4.4.4 Late- to post-klaematic plutons

Dates from the discordant Mao and Bonga plutons are in marked contrast to those of the Birbir quartz diorite sheets and the Goma granodiorite pluton discussed above. Data from 5 samples from the Mao pluton (Fig. 4.8) yield a Rb-Sr whole-rock isochron date of $552+/-41 \mathrm{Ma}$, an intercept of $0.70355+/-0.001$, and an MSWD-1.3. The large uncertainty attached to the calculated age is mainly due to a very small spread in ${ }^{87} \mathrm{Rb} /{ }^{86} \mathrm{Sr}$ ratios.

The near-concordant lower intercept U-Pb age of $550 \mathrm{Ma}$ and the Rb-Sr isochron date of $552 \mathrm{Ma}$ from the same pluton are interpreted as the best estimate of the age of intrusion of the Mao pluton. The pluton is later than the major shearing in the BSZ, because it cuts the main mylonitic fabric in the surrounding country rock. Because the pluton is, however, sheared along its eastern margin, the latest movements on the BSZ post-date ca. $550 \mathrm{Ma}$.

The granite rim of the Bonga pluton yielded a six point scatterchron of $540+/-10 \mathrm{Ma}$, an intercept of $0.70578+/-0.001$ and an MSWD=7.2 (Fig. 4.9). A U.Pb age of $571+11 /-3 \mathrm{Ma}$ was obtained from the quartz monzonite core of the same pluton. An intrusive contact of the granite into the quartz monzonite indicate that the rim is later than the core. Both varieties are undeformed, and straddle the boundary between the Birbir and Baro domains. Thus, the 571 Ma emplacement date clearly puts a minimum age limit on strain history along the border and perhaps on the timing of most transcurrent movement in the Birbir Domain. 


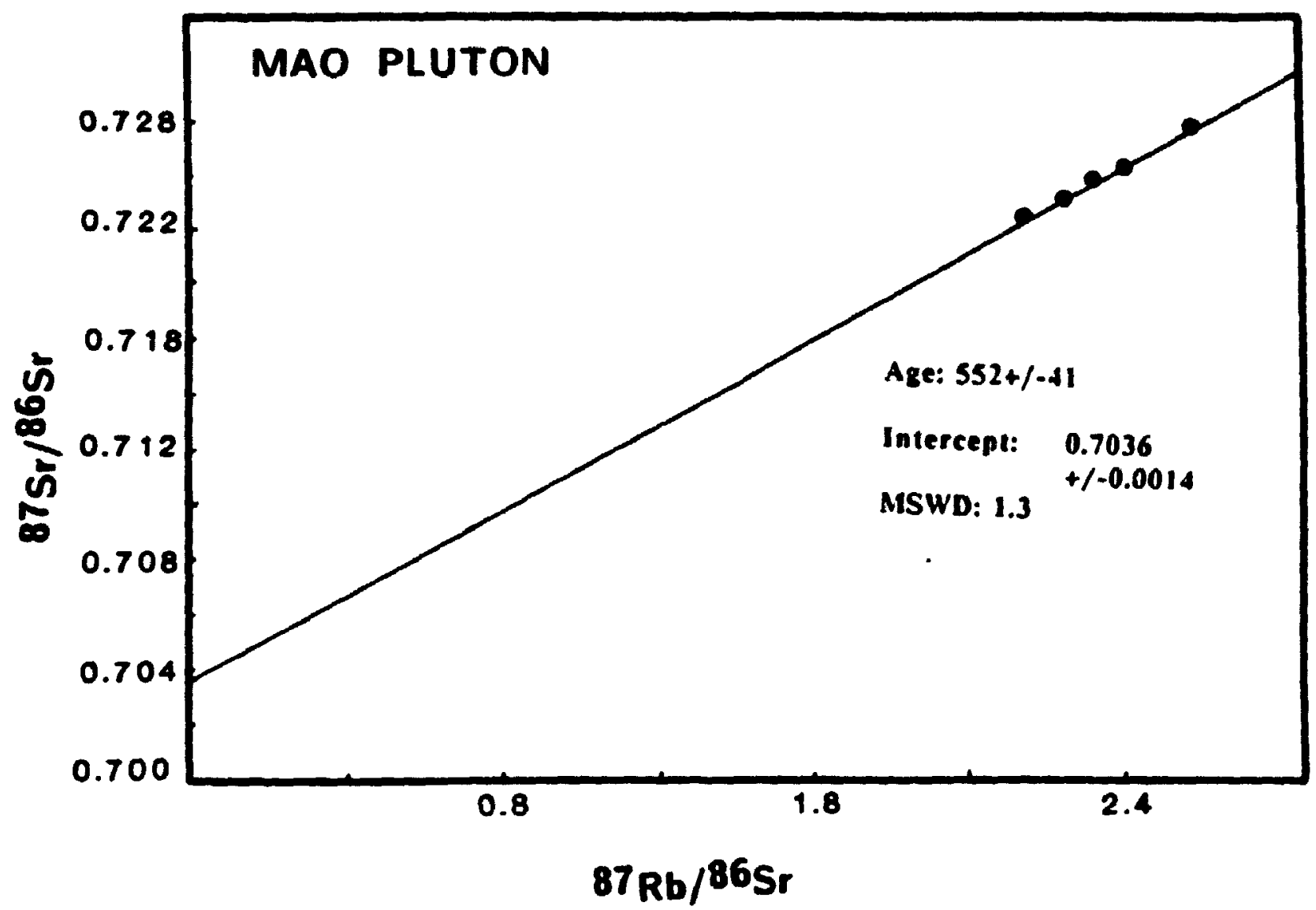

Figure 4.8: 1sochron flot for the Mao pluton. 


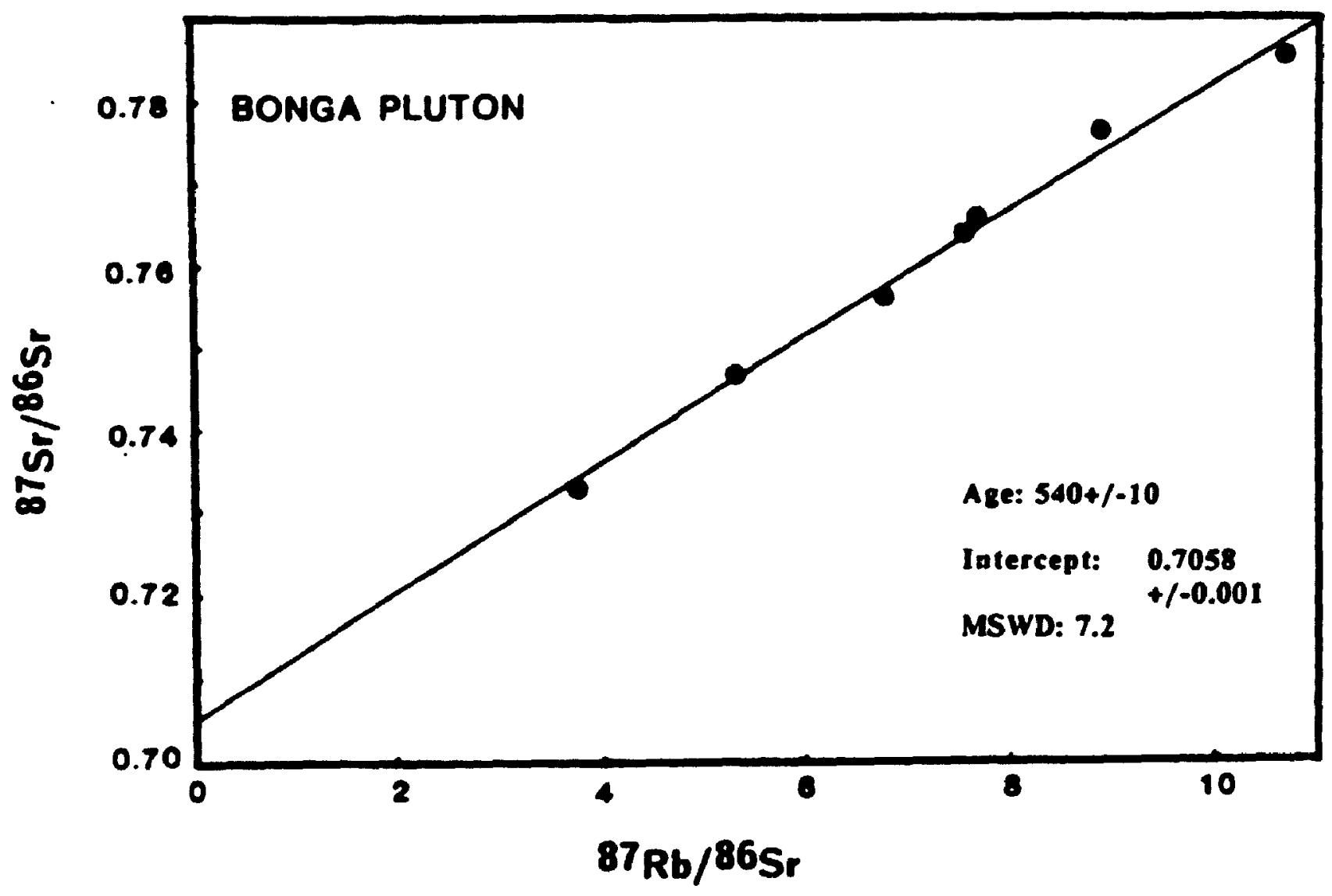

Figure 4.9: Isochron plot for the Bonga pluton. 


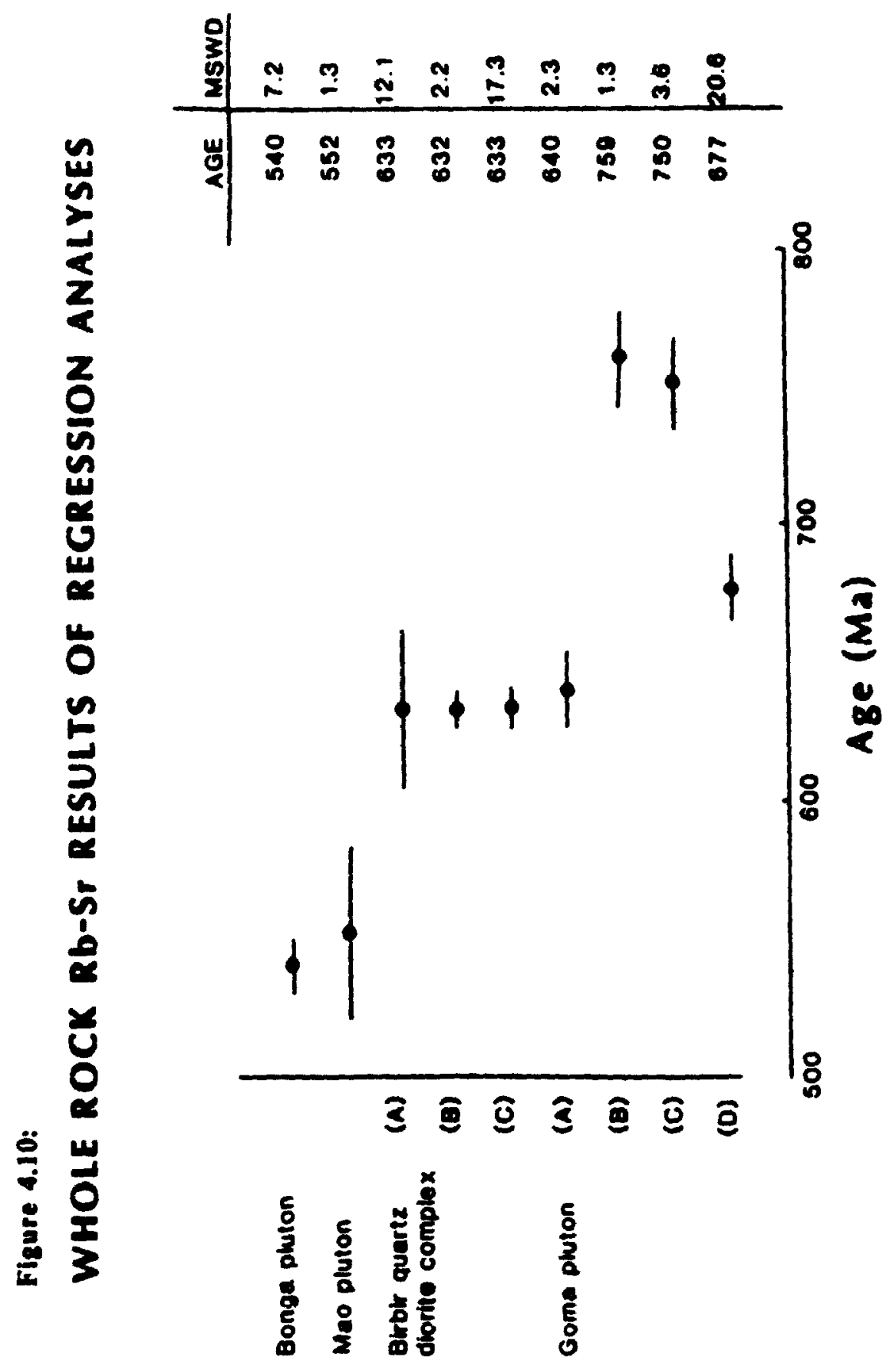




\subsubsection{Rb-Sr wiaeral dates}

Of all of the plutons, the Birbir quartz diorite complex is the most affected by the BSZ. The complex is made up of three major sheets, separated by schists and mylonites. One sample was selected from each of the sheets. and biotite separated for Rb-Sr analyses. Biotite and hornblende define a mylonitic foliation in these rocks. Biotite constitutes 8 to $12 \%$ of the mode and occurs as elongate flakes, 0.4 to $3 \mathrm{~mm}$ long and 0.1 to $1 \mathrm{~mm}$ wide.

Using the whole-rock and the biotite data from the same sample it was possible to calculate three two-point isochrons. Calculated dates are $426 \mathrm{Ma}$ (sample * TSG; sample locality shown in Fig. 2.3) from the western quartz diorite sheet, $543 \mathrm{Ma}$ (T3H) from the central sheet and $680 \mathrm{Ma}$ (T8I) from the eastern sheet. These dates represent the time at which the biotites became closed systems, i.e. marking the time since they dropped below the temperature at which radiogenic Sr stops diffusing and begins to accumulate in the system. Estimated blocking temperatures have been determined at 250 $311^{\circ} \mathrm{C}$ for biotites (Hoffmann and Gilletti, 1970). These dates are consistent with K-Ar and Rb-Sr mineral dates Irom rocks affected by the Pan-African thermal event of Kennedy and others (see Cahen et al., 1984).

The dates from the three biotite - whole-rock pairs decrease from east to west. This may result either from westward migration of shear strain in the BSZ with time, or progressive cooling of a heat source located to the west. provided by thickened continental crust of the Baro Domain.

\subsubsection{Rb and Sr coacentrations and Sr isotopic compositions}

Much use has been made of the petrogenetic application of Rb-Sr 
systematics (De Paolo and Johnson, 1979; Allegre and Othman, 1980). The $\mathrm{Rb} / \mathrm{Sr}$ ratios for the low-K suite (Bure and Haya plutons) range ' :tween $0.0 \mathrm{i}$ and 0.04 , in contrast to the ratios for the calc-alkaline suite that range between 0.11 and 0.17 . The trend in $\mathrm{Rb} / \mathrm{Sr}$ ratio of Group (1) pre-kinematic rocks is consistent with other field and chemical data suggesting that both low-K and calc-alkaline suites could be members of an evolving consanguineous series. if so, these data indicate that the low-K rocks are olde: than the eadi-a!kaline suite. $\mathrm{Rb} / \mathrm{Sr}$ ratios of the late to postkinematic, alkalı-ieldspar granites are generally higher than 0.8 (mean values for $\mathrm{MaO}=0.83$, Bonga $=2.4$ ). The increase in $\mathrm{Rb} / \mathrm{Sr}$ ratio also agrees with other chemical distinctions of the late- to post-kinematic plutons of Group (3) that reflect their derivation from much more evolved magmas than those of Group (1) plutons. The low Rb/Sr ratios (<7.2) which characterize the pre- to syn-kinematic plutonic units from the Birbir Domain resulted in high errors attached to whole rock isochron ages (see York. 1969).

${ }^{87} \mathrm{Sr} /{ }^{86} \mathrm{Sr}$ intercepts from the re-set isochrons are uniformly low: < $<0.704$ for Group (1) plutons, 0.7036 for the Mao pluton, and 0.7058 fur the Bonga pluton. Because the systems are re-set, their intercepts represent maximum values for the initial Sr isotope ratio of the magma. The re-set isochron intercept values therefore are considered to be maximum values for the initial ratios of the original magmas.

All of the calculated initial ${ }^{87} \mathrm{Sr} /{ }^{86} \mathrm{Sr}$ ratios are low, close to the late Proterozoic mantle alues (Powell and Faure, 1972), suggesting that the plutons are derived from a source with low $\mathrm{Rb} / \mathrm{Sr}$ ratio similar to that of 
the mantle or lower crust, or generation from a fairly young crustal segment. The $\mathrm{Rb} / \mathrm{Sr}$ and initial Sr ratios are sufficiently low to preclude any significant contribution from a long-lived, upper crustal source.

\subsection{SUMMARY}

The results of this geochronological study help to constrain the ages of the plutons and their subsequent history. No evidence of older basement to the oldest Pan-African rocks was obtained. A number of significant conclusions can be drawn from the isotopic data coupled with the geological and geochemical data provided in previous chapters. These are:

1- U-Pb zircon ages of $828+/-5$ and $814+/-2$ Ma were obtained from Group (1) pre-kinematic plutonic units, indicating two distinct ages of emplacement in what may be part of a continuum of magmatic events in the Birbir Domain. The low initial ${ }^{87} \mathrm{Sr} /{ }^{86} \mathrm{Sr}$ ratios $(0.7028$ and 0.7040$)$ from the same plutonic units denote values very close to that of the late Proterozoic mantle and thus indicate that there was no contribution to the magmas by crustal rocks substantially older than the age of isotopic redistribution. The ages date the earliest known igneous activity in the Birbir Domain.

The low-K suite could not be dated during this study because of unfavourable $\mathrm{Rb} / \mathrm{Sr}$ ratios and low zircon content.

2- The Baro leucogranite zircons yielded a mixing line on the concordia plot with an upper intersection of $783+19 /-14$ Ma and a lower irtersection at 582 $+29 /-33 \mathrm{Ma}$. The semi-concordant relationship with country rocks, presence of pelitic schieliern and overall aluminous chemistry suggest that the Baro 
granite resulted from large scale anatexis in the Baro Domain. The upper intersection date is inferred to represent the age of syntectonic intrusion of an anatectic melt. The re-set $\mathrm{Rb}-\mathrm{Sr}$ isochron corresponding to a date of $759+/-18 \mathrm{Ma}$, indicated by the less-deformed samples from the Goma pluton, points to a thermal event that postdates its emplacement but agrees within uncertainty with the time of intrusion of the Baro leucogranite. Emplacement of the Baro leucogranite denotes a high-grade regional metamorphic event that is also reflected in resetting of isotopic systems at ca. $760 \mathrm{Ma}$ in the Birbir Domain. If an anatectic origin for the Baro leucogranite is accepted. then the $783 \mathrm{Ma}$ zircon age represents an approximate time of high-grade metamorphism in the Baro Domain, and the ca. 783-760 Ma interval defines a $\therefore$ ariod of regional metamorphism across the Birbir and Baro domains. The metamorphism is represented by high-grade metamorphic mineral assemblages such as sillimanite, gedrite and $K$-feldspar, which formed contemporaneously with the development of gneissic foliation in the Baro Domain.

The timing of this metamorphism also correlates with the age of deformation and epizonal metamorphism at $761+/-22 \mathrm{Ma}$ of arc-related rocks from Abu Hamed, in the Southern Red Sea Hills of the Sudan (Ries et al., 1985), at $750+/-29$ Ma from the Bayuda desert in central Sudan (Meinhold. 1979), and in the Western Arabian Shield (Jackson and Ramsay, 1980). It also correlates with a metamorphic event loosely defined for Mozambiquian rocks of Kenya in the range of 750-850 Ma (Shibata, 1975; Suwa, 1979).

The $582+29 /-33 \mathrm{Ma}$ lower intersection is interpreted as the age of the latest high temperature metamorphic overgrowth of zircon. This event probably corresponds to the growth of large garnet porphyroblasts and 
randomly oriented sillimanite (fibrolite) in unit (8s8). The ca. $580 \mathrm{Ma}$ date correlates with the age of amphibolite facies metamorphism in the nearby Mozambique Belt of NW Kenya (Ries et al., usinublished).

3- The Rb-Sr isotope systems of the Group (1) pre-kinematic intrusive units show variable degrees of isotopic re-equilibration which can be attributed to heterogeneous deformation. The regressed values of different data sets from the Birbir quartz diorite and Goma pluton of the Birbir Domain cluster of about $635+/-8 \mathrm{Ma}$ (Fig. 4.10), providing evidence for significant isotopic homogenization during a late Proterozoic event. This event is probably associated with major transcurrent movement on the Birbir Shear Zone, age of mylonitization.

The ca. $635 \mathrm{Ma}$ time of isotopic homogenization in rocks of the Birbir Domain and the metamorphic age at ca. $580 \mathrm{Ma}$ inferred from rocks of the Baro Domain may represent parts of a protracted metamorphic event that affected rocks of both domains.

4- U-Pb data from the late-tectonic Mao granite, that cuts the main mylonitic fabric of the Birbir Shear Zone but is itself marginally deformed, also define a mixing line, in this case between pre-intrusion zircon cores and predominant igneous overgrowths. The lower intersection dates the time of intrusion at $541+10 /-16 \mathrm{Ma}$, and the poorly-constrained upper intersection indicates zircon of ca. $770 \mathrm{Ma}$, that may have been generated at the same time as the Baro leucogranites. The Bonga granite, intruded across the boundary zone of the Birbir and Baro domains, contains a concordant zircon population whose age is $571+11 /-3 \mathrm{Ma}$. Together the dates mark the 
termination of tectonic and intrusive activity at about $550 \mathrm{Ma}$.

5- Initial Sr isotope ratios for groups (1) and (3) plutons of the Birbir Domain are estimated at $<0.704$ and $<0.706$ respectively, implying no significant contribution of older crust to the generation of these rocks. The intercepts, obtained from re-set systems, are maximum values, thus they point to a mantle-like source. 


\section{CHAPTER 5}

\section{DISCUSSION AND INTERPRETATION}

\section{S.1 GENERAL STATEMENT}

Mapping at the scale of 1:50,000, supported by chemical studies, has indicated distinct periods of plutonism and tectonothermal activity within the Birbir and Baro Domains. Three generations of plutonic rocks are recognized. Group (1), the earliest generation, consists of pre- to synkinematic, mafic and intermediate intrusive complexes. A second group is made up of marginally peraluminous, probably anatectic granites and a third. younger, group comprises alkali-feldspar granites.

Because the area has been affected by regional metamorphism and shezring, it is not clear to what extent the rocks have remained as closed chemical systems. Systematic variation, however, in major and trace element distribution, including the REE, suggests restricted elemental mobility. The absence of significant retrograde metamorphic features, typical of many rocks affected by shearing, implies either a limited fluid circulation, an anhydrous environment, or perhaps cessation of shearing before drop in temperature.

The trace element variations and REE patterns of samples from Group (1) reflect are-type magmatism, while Groups (2) and (3) reflect intraplate activity. Chemical data from Group (1) define two distinct suites: a low-K suite of oceanic affinity and a calc-alkaline suite similar to that of an Andean-type arc. A steeply-dipping ductile transcurrent fault system, the Birbir shear zone (BSZ), transects the two suites of Group (1) rocks. The 
calc-alkaline suite possesses low ${ }^{87} \mathrm{Sr} /{ }^{86} \mathrm{Sr}$ initial ratios, less than 0.7037, implying little or no contribution from older continental crust.

The overall petrologic and chemical features suggest that the Group (1) rocks formed in a subduction-related tectonic setting.

\subsection{REGIONAL LITHOTECTONIC ASSEMBLAGES}

Although geological investigations of the Precambrian rocks in the Afro-Arabian region began in the first half of this century, an understanding of the stratigraphic, structural and tectonic features has remained elusive. It is possible however to recognize three types of regional lithostructural domain (Figs. 1.2 and 5.1 ) that are similar to those in western Ethiopia and the Geotraverse area. Recent geological investigations of the Precambrian rocks of NE Africa and Arabia are represented by the contributions to the International Geological Correlation Programme (IGCP. Project 164). Of particular importance are the contributions of Al Shariti and Mitchell (1976). Greenwood et al. (1976). Gass (1977, 1979), Kroner (1977), Shackleton (1977), Kazmin et al. (1979), Engel et al. (1980), Bokhari and Kramers (1981), de Wit and Chewaka (1981). Duyverman et al. (1982), Al Shanti and Gass (1983), Ries et al. (1983), Vail (1983, 1985), Harris et al. (1984), Kroner (1985), Jackson (1986) and Shackleton (1986). Their ideas are summarized in the following sections in an attempt to relate the domains in the study area to those found elsewhere in the region.

\subsubsection{Volcano-sedimentary terranes}

The volcano-sedimentary terranes contain calc-alkaline basalt, andesite 


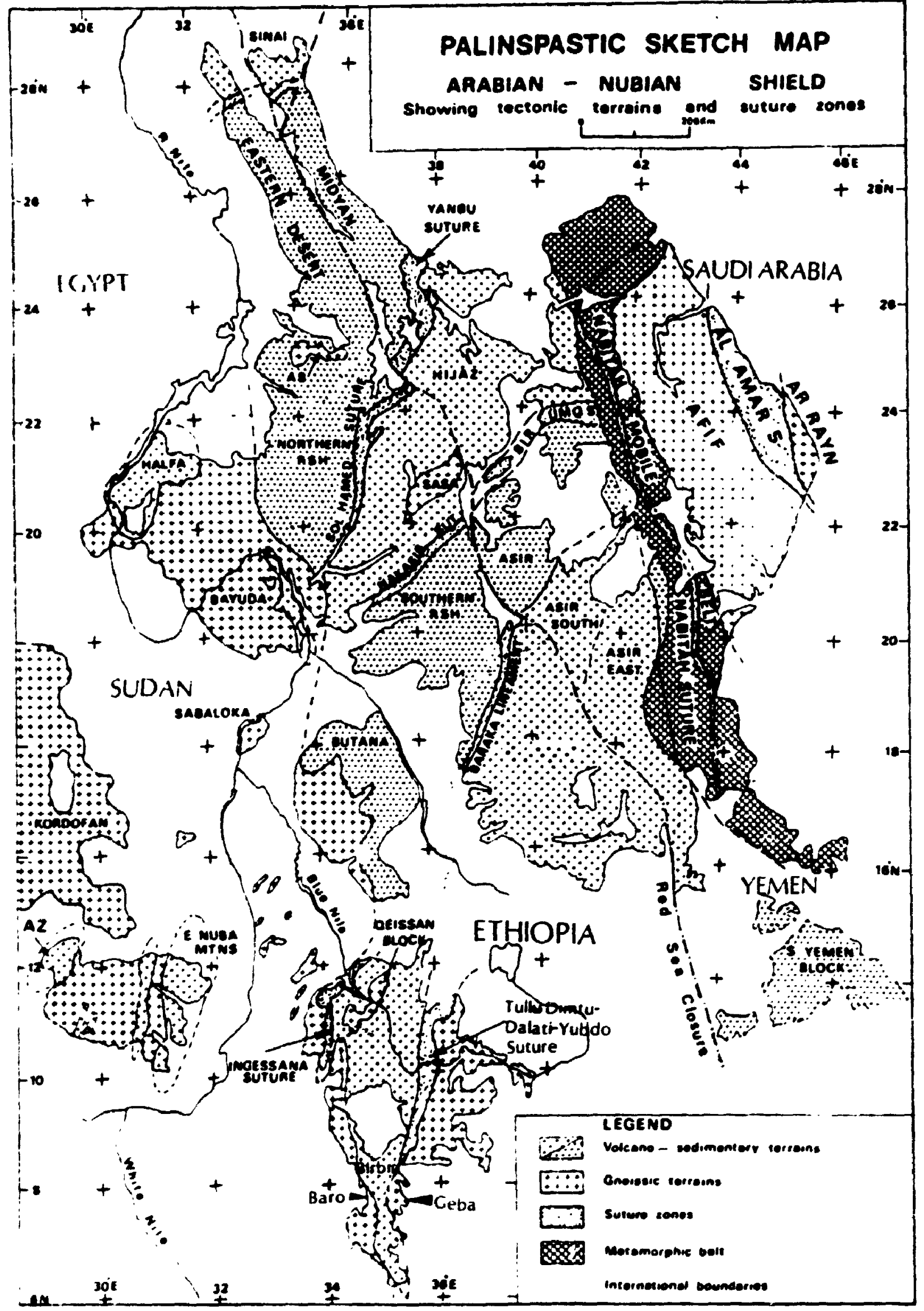

Figure 5.1: Palinspastic sketch map of the region showing main tectonic terranes. (Modified after Vail, 1985). 
and rhyolite flows, tuffs and pyroclastics. Voluminous sedimentary rocks are common and include wackes, thin layers of marble and quartzite, pebbly mudstones and conglomerates and rare ironstones. These units are characteristically at greenschist to lower amphibolite facies grade of metamorphism and are extensively intruded by plutons of mafic and intermediate to granitic composition.

At least five such belis can be identified in NE Africa and Arabia (Fig. 5.1); each seems to be geologically discrete and each appears to have evolved independently. It is now generally accepted that most of these terranes developed as island arc-ocean basin complexes < I Ga ago (Engel et al., 1980; Fleck et al., 1980; Bokhari and Kramers, 1981; Calvez and Kemp. 1982; Duyverman et al., 1982; Roobol et al., 1983; Stacey and Stoesser. 1984). To the north, these arc-ocean complexes appear to terminate in the gneissic terrane of northeastern Egypt and southern Sinai (Stern, 1979). These can be traced into Arabia where their origin is ascribed to a series of events called the "Hijaz cycle" (Ramsay, 1979). To the south they branch into Ethiopia and the Sudan, where they narrow and become truncated by a major fault system, the Surma mylonite zone (Fig. 1.3).

\subsubsection{Ophiolitic rocks}

Rocks that may be members of an ophiolite suite ("suture zones" in Fig.

5.1) are widespread throughout NE Africa, and have been described in Ethiopia (Kazmin, !976, 1978a, 1979; de Wit and Chewaka. 1981). Egypt (Shackleton, 1977; Shackleton et al., 1980), Sudan (Fitches et al., 1983) and Kenya (Vearncombe, 1981). Narrow discontinuous belts of ultramafic 
rocks, gabbros, serpentinites, rare sheeted dykes, pillowed tholeiitic basalts and associated sedimentary rocks such as turbidites, chert, marble and volcaniclastic rocks have been described. Because of their linear nature, the ophiolitic belts are considered to represent boundaries of convergence or suture zones developed between continental and island arc terranes (Gass, 1979; de Wit and Chewaka, 1981; Vail, 1983; Stoesser and Camp, 1985; Kroner, 1985).

The absence of well-defined accretionary prisms, ophiolitic melanges and high-pressure metamorphic assemblages led Kroner (op.cit.) to suggest that cither accretion did not occur along margins with deep ocean trenches. or extensive overthrusting took place so that the forearc segments were overriden and concealed. Fyfe (1979) commented on the lack, in the late Proterozoic rocks of NE Africa and Arabia, of low-temperature - high pressure metamorphic facies commonly associated with subduction environments, and concluded that this lack of blueschists reflects plate movements of only a few hundred kilometres. An ophiolite emplacement mechanism :clated to subduction processes seems nonetheless to be widely accepted by most investigators (see Vail, 1985; Jackson, 1986a).

\subsubsection{Gneissic terranes}

These consist of heterogeneous ortho- and paragneisses and migmatites of generally upper amphibolite to granulite grade of metamorphism. These terranes are thought to be older than the volcano-sedimentary terranes, but few rocks older than late Proterozoic have been conclusively identified. Although the data base is limited, there are a few dates from Sudan and 
Egypt that suggest Archean to a mid-Proterozoic foreland/basement underlying the western side of the Pan-African rocks in NE Africa (see section 4.1 ).

On a regional scale, some of the gneisses occur as isolated inliers within wide belts of the volcano-sedimentary terranes. These are now mostly interpreted as remnants of pre- Pan-African microcontinents, representing exotic terranes accreted by oblique collision and strike-slip translation (Kroner, 1985; Stacey and Agar, 1985).

\subsection{RELATIONSHIP OF THE BIRBIR DOMAIN TO THE PAN-AFRICAN ARC-TYPE ROCKS}

Rocks of the Birbir Domain are traceable northwards into the PanAfrican Asir, southern Red Sea Hills and Butana terranes of north-east Africa and Arabia (Figs. 1.2 and 5.1). The stratified rocks of these terranes are like those of the Birbir Domain are now generally in the lower amphibolite facies of metamorphism, and they have been extensively intruded by pre- and syn-kinematic, low-K and widespread calc-alkaline rocks of batholithic dimensions and by late alkalj-feldspar granites. The voluminous calc-alkaline magmatism is ascribed to subduction processes giving rise to a number of magmatic arcs, that have been accreted to one another and to oceanic and continsntal fragments. A magmatic are affinity is also suggested by trace element discriminant plots for the pre- and syn-kinematic rocks of the Birbir Domain. ${ }^{87} \mathrm{Sr} /{ }^{86} \mathrm{Sr}$ intercepts for the Birbir calc-alkaline suite indicate that they are unlikely to have been derived (rom much older crusta) sources. On the eastern border of the Birbir Domain, to the north of the study area, the linear Tullu Dimtu mafic/uitramafic belt, that is thought to 
be composed of dismembered ophiolitic rocks, can be traced into the ophiolitic rocks of the Baraka lineament of northeast Africa. If the basement were merely thinned underneath the Birbir Domain, there would not be widespread calc-alkaline rocks nor would oceanic rocks be associated. The evidence thus follows a cycle of ocean opening and closure, rather than an ensialic origin, for the Birbir Domain, similar to the model for the PanAfrican terranes to the north.

South of the study area, rocks of the Akobo Domain are continuous with those of the Birbir Domain and have a wedge-shaped configuration; they terminate at a major tectonic front, the Surma mylonite zone (Davidson. 1983). The narrowness of the Birbir Domain in the study area compared to its northerly extension, where it reaches a strike - normal width of over 200 $\mathrm{km}$. was probably due to a reduction in width of a proto-ocean basin at the latitude of the study area, and also possibly to increased shortening at this latitude. The boundary between the Birbir and the gneissic terrane to the west probably represents a mylonitic cryptic suture. To the north, where the wedge-shaped Pan-African rocks widen, ocean opening may have been considerable and plate convergence with subduction of oceanic crust could have continued for an extended period.

In conclusion, the Birbir Domain of western Ethiopia exhibits similarities in field relations and lithological, elemental and isotopic characteristics to the magmatic are systems of Pan-African rocks to the north in northeast Africa and Arabia. 


\subsection{RELATIONSHIP OF THE BARO AND GEBA DOMAINS TO TIIE MOZAMBIQUE BELT DF EAST AFRICA}

Rocks of the Mozambique Belt can be traced from NH senya through the Hamar Domain of the Omo Project area (Davidson, 1983) into the Geba Nomain of the Geotraverse area. Although the Baro Domain ean not be traced directly into the Mozambique Belt, its predominantly sialic lithology, metamorphic grade indicating mid-crustal level (medium-pressure, high-lemperature metamorphism), and apparently polyphase deformation sugzest that it may be the northward continuation of the Mozambique Belt in NW Kenya.

Field relations and chemical data from Group (2) rocks in the Baro Domain suggest anatexis of a sedimentary source. These rocks are interpreted as having been emplaced during folding and migmatization at ca. $780 \mathrm{Ma}$, initiated by thickening of a continental margin following the emplacement of the calc-alkaline suite. The Baro leucogranite yielded a U.Pb zircon lower intersection date of about $580 \mathrm{Ma}$, that clearly marks a later major thermal event contemporaneous with amphibolite facies metamorphism in NW Kenya. According to Gabert (1984), the Mozambiquian "event" should be restricted to a thermal event at about $550+/-100 \mathrm{Ma}$; this period includes the time of the ca. $580 \mathrm{Ma}$ high-grade metamorphic event in the Baro Domain. Thus the latest high-grade amphibolite facies metamorphism, without major contemporaneous deformation, in the Baro Domain of western Ethiopia can be correlated with the thermal event that affected rocks of the known Mozambique belt. This coincidence adds strength to the correlation of Baro Domain rocks with the Mozambique belt of NW Kenya. 


\subsection{RELATIONSHIP OF THE MOZAMBIQUE BELT ROCKS TO THE}

\section{PAN-AFRICAN ROCKS IN WESTERN ETHIOPIA}

There is as yet no geochronological evidence from the study area that supports the view that rocks of the Baro and Geba domains are older than those of the Bisbir Domain. Geochronological evideace from areas adjacent to the Mozambiquian rocks, not influenced by the Pan-African event, yield ages as old as 2900 and $2600 \mathrm{Ma}$ for the Dodoman System in the Tanzanian Craton (Bell and Dodson, 1981 ) and about $1900 \mathrm{Ma}$ for the Usagaran - Ubendian rold belt (Gabert. 1984). Detrital zircons from granulites at Sabaloka on the Nile north of Khartoum yiclded ages that range from ca. 2650 to $1000 \mathrm{Ma}$ (Kroner et al., 1987) that mark the involvement of Archean to late Proterozoic continental crust in the evolution of the high-grade rocks to the west.

Nd isotope studies have identified important differences in the character of the various crustal provinces across northeast and east Africa. Peraluminous granites (Marich granite) from an area of high metamorphic grade in Nh' Kenya, similar to Group (2) plutonic units, have negative " ${ }^{\prime}(T)$ values and suggest crustal precursors older than $1650 \mathrm{Ma}$ (Harris et al., 1984). Nearby lower-grade Pan-African rocks have positive ${ }_{\mathrm{E} d}(\mathrm{~T})$ values, suggesting a mantle-type source and little or no contamination by crustal rocks, and younger model ages than the rocks from the high grade metamorphic terrane. This interpretation supports the view that the rocks of the Birbir Domain, considered tc be Pan-African, aze younger than those of the Baro Domain in the western Ethiopian Shield. 
The ages obtained in this study however demonstrate that part of the plutonic and metamorphic evolution of the Baro Domain is synchronous with that of the Birbir Domain. At least two distinct metamorphic events with ages between $780-760$ and $635-580 \mathrm{Ma}$ have aftected both domains. Similar age relations were found in Pan-African rocks of the Bayuda desert in the northeast African shield (Fig. 5.1; Pohl, 1981).

Although field relationships are not conclusive, high-grade rocks of the Baro Domain appear to be overlain by wedges of metaclastic sedimentary rocks (unit ams) of continental derivation. These wedges are thought to have been formed at a plate margin, on the basis of the chemical characteristics of the associated plutonic rocks and the presence of a ductile transcurren: rault system, the Birbir Shear Zone (BSZ), that marks a tectonic contact between the contrasting Baro and Birbir domains. The Baro Domain is thus suggested to be a zone of tectonic reworking in the foreland to the Mozambique Be!t, during the Pan-African events. Kroner (1977) similarly regarded the gneissic terranes to the north, in Egypt and Sudan as indicating transformation of a passive continental margin into a tectonically-active belt along which ophiolites and magmatic arc rocks were thrust over each other and/or onto the gneisses.

The western boundary of the Birbir Domain contains plutonic units chemically similar to those of an active continental margin (Andean-type). The Baro Domain contains leucogranites whose petrology and chemistry implics a sedimentary source. The available ;idence fur the origin of these plutonic rocks suggests anatexis in a tectonically active continental margin on the eastern side of the Baro Domain. The eastern boundary of the Birbir 
Domain is also a tectonic one, marked by truncation of a major antiform in rocks of the Geba Domain.

In the western marginal zone of the Mozambique Belt of NW Kenya, Vearncombe (1983) reported ophiolitic rocks in the Sekerr area that may correlate with those in western Ethiopia. These features led Shackieton (1986) to conclude that the Mozambique Belt, at least as far south as NW Kenya, evolved as a result of continent-continent collision.

Penetrative deformation accompanied by migmatization and upper almandine amphibolite facies metamorphism may have obscured earlier structures and re-set isotopic systems within these high-grade metamorphic rocks. In order to better understand their h:story, precise U-Pb dating of mincrals such as zircon and monazite will be necessary. Although it can not yet be puven, the Baro and Geba domains appear to be older than the crust generated during the Pan-African event.

\subsection{AGE AND CORRELATION OF PLUTONIC AND METAMORPHIC EVENTS}

The age spectrum of plutonic units from the Gore - Gambella area is broadly similar to that established for Pan-African rocks to the north along strike in Sudan, Egypt and Saudi Arabia, and in the Mozambique Belt of East Africa (Table 5.1).

Calc-alkaline plutonic socks of the Birbir Domain are dated at ca. 830$815 \mathrm{Ma}$ and are probably related to subduction. The earlier presence of oceanic crust is supported by mafic/ultramafic rocks of probable ophiolitic affinity to the north (Fig. 5.1), in the Tullu Dimtu - Dallati - Yubdo Belt. The period ea. $760 \mathrm{Ma}$ is considered to be the age of earliest regional 
Table 5.1: Tentative age correlation of plutonic and metamorphic rocks from western Ethiopia with Pan-African rocks in the Sudan and Saudi Arabia, and known rocks of the Mozambique Belt from NW Kenya.

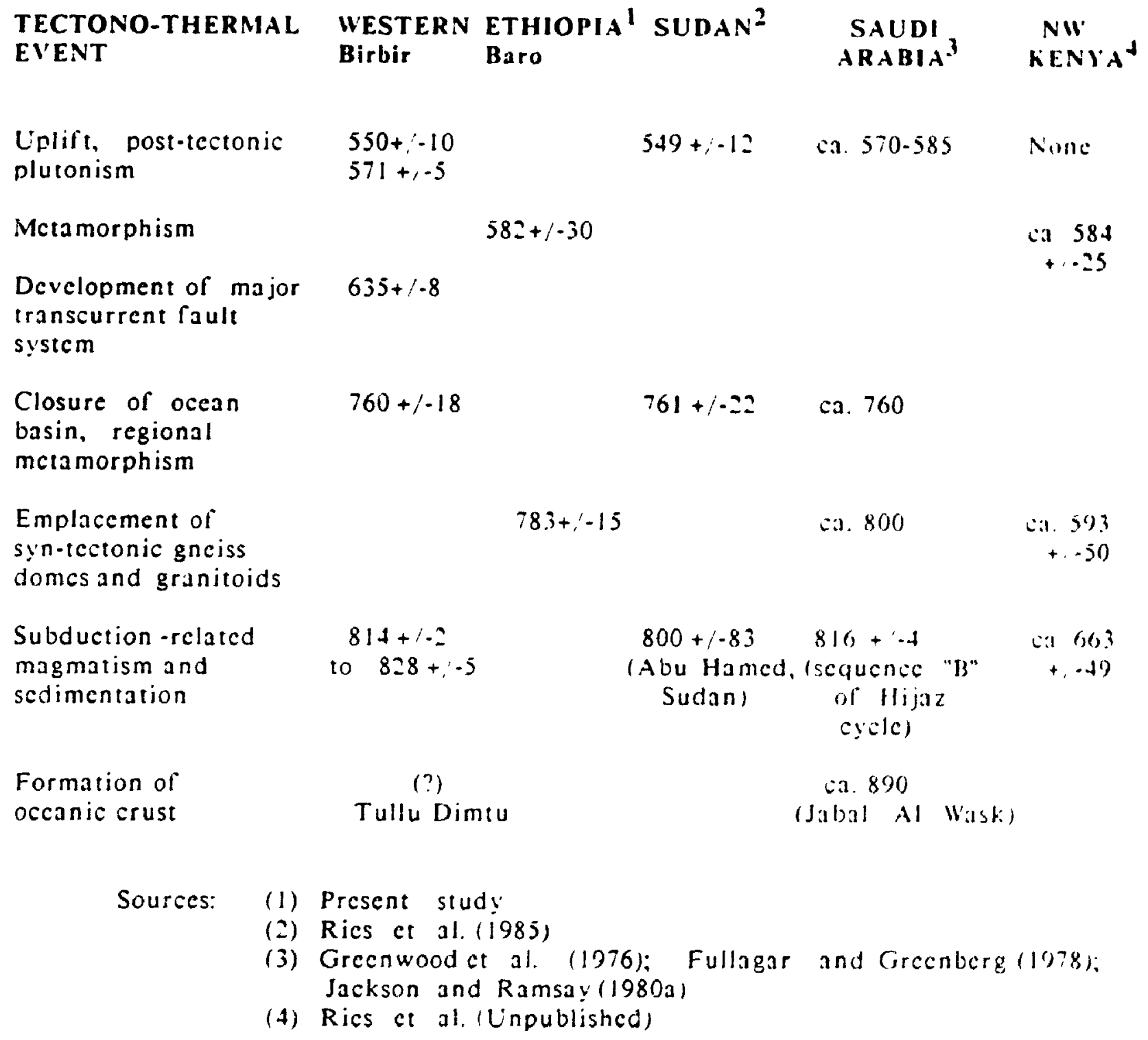


metamorphism in Pan-African rocks of western Ethiopia. This interval seems

to represent the time of juxtaposition of an intra-oceanic island arc.

represented by the low-K suite, with the calc-alkaline suite of continental

margin-type along the BSZ. High-grade metamorphism in the Baro Domain at ca.

$780 \mathrm{Ma}$ is also attributed to this event.

The timing of the regional metamorphism across the Birbir and Baro domains is similar in age to low-grade metamorphic activity associated with arc-related rocks at $761+/-22$ Ma from Abu Hamed, in the central part of northern Sudan (Ries et al., 1985) and 750+/-29 Ma from the Bayuda desert (Meinhold, 1979). It also correlates with a thermal event loosely defined for Mozambiquian rocks of Kenya in the range of ca. 750-850 Ma (Shibata, 1975: Suwa. 1979).

A later metamorphic event in the Birbir Domain may also be defined. at ca. $635 \mathrm{Ma}$. as the time of an isotopic readjustment probably related to major transcurrent movement along the Birbir Shear Zone. Metamorphic overgrowth of zircons in the Baro leucogranite at $582 \mathrm{Ma}$ is considered to represent the last metamorphic event recorded in Mozambiquian rocks in western Ethiopia. Thus a second distinct period of metamorphism, including onc or more events in adjacent, contrasting metamorphic domains, can be constrained to ca. $635-580 \mathrm{Ma}$. In NW Kenya, the $584 \mathrm{Ma}$ event from rocks of the Mozambique Belt also marks a second regional metamorphism younger than that of the Pan-African rocks in NE Africa (-760 Ma).

\subsection{TECTONIC MODEL}

The abrupt change in metamorphic grade from the Birbir into both the 
Baro and Geba domains, the tectonic contacts separating them and the chemical distinction of the plutonic units and all suggest tectonic juxtaposition of newly generated crustal material with pre- Pan-African continental crust. The model of shield microplate accretion that has been applied to the Afro-Arabian region (Gass, 1981; Vail, 1985) thus seems to fit the observations from the western Ethiopian Shield. A mylonitic cryptic suture is suggested to occupy the study area, containing are material represented by the low-K suite, welded between older continental masses: the Baro Domain to the west and Geba Domain to the east. Both the Baro and Geba domains are interpreted to represent continental crust.contiguous with the Mozambique Belt to the south. The Baro Domain is here interpreted as part of the basement system of the African foreland that has been affected by PanAf rican remobilization.

The proposed tectonic evolution of the western Ethiopian Shicld involved the following steps: (a) breakup of a continental mass and subsequent development of an ocean busin, (b) initiation of a short-lived marginal basin and/ur intra-oceanic subduction zone producing magmatic arcs both within the continental margins and on the oceanic crust, and (c) subsequent closure.

There is no evidence from this study concerning the nature and timing of continental rift and ocean development. The remainder of the evolutionary scheme can be broadly divided into three periods: pre-accretionary. accretionary and cratonization as shown in Figure 5.2. The pre-accretionary period started before ca. $830 \mathrm{Ma}$ (Fig. 5.2A; stage 1) and involved formation of an island arc and the subsequent destruction, through subducion, of oceanic lithosphere. As subduction continued this arc was accreted to the 


\section{(A) Pre-accretionary period}

1. Subduction: pre (?)830 $\mathrm{Ma}$

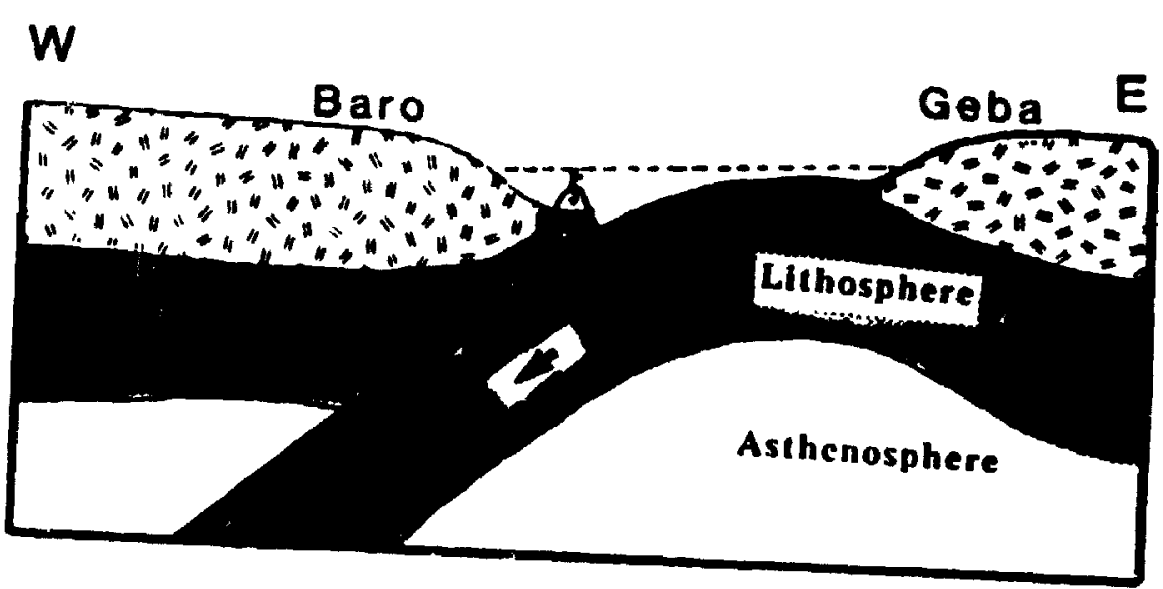

(B) Accretionary period (830-635 Ma)

2. Subduction ( $830-760 \mathrm{Ma})$

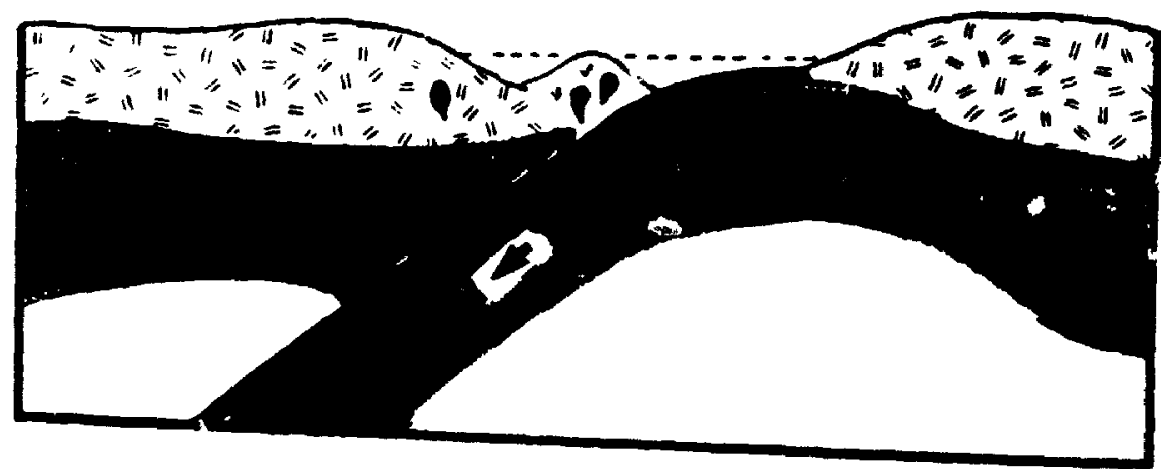

Continental crust

Oceanic crust
2 Volcanic and sedimentary rocks

Cranitoid rocks

Figure 5.2: Cartoon to

Litiopia during latc Protcrozoic.

tectonic crolution or westcrn 
3. Development of transcurrent fault system (765-635 Ma)

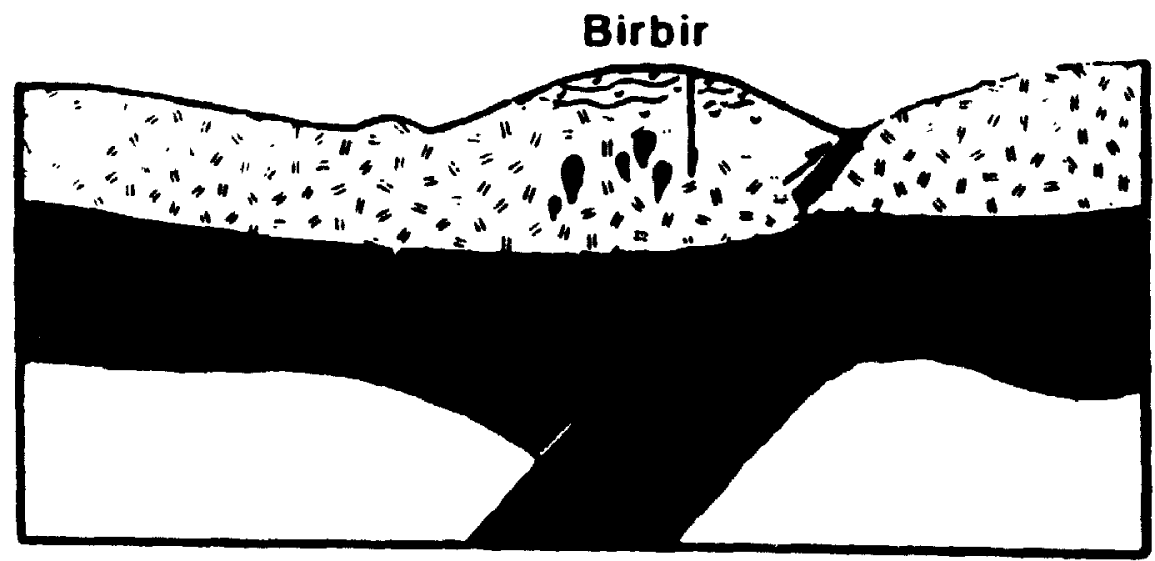

(C) Cratonization period (635-540 Ma)

4. Back-arc spreading (?)

5. Uplift and erosion

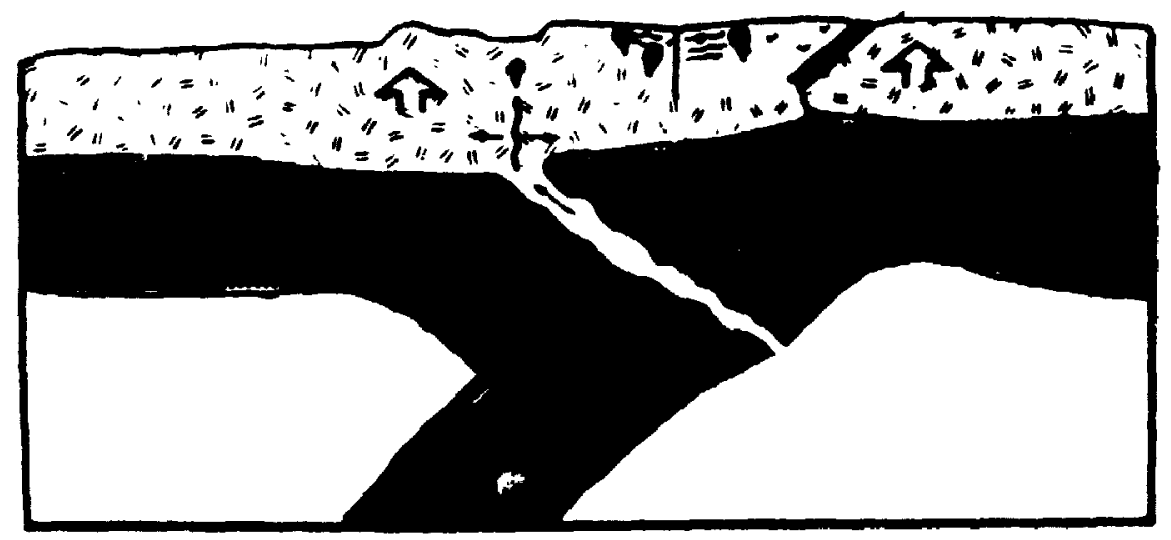

Figure 3.2 (conlinusd): 
continental margin (Fig. 5.2B; stage 2). A westerly dipping subduction zone is shown in Figure 5.2, based on a generalized westward tectonic transport direction including fold vergence suggested by de Wit and Chewaka (1981) and Shackleton (1986) for rocks along strike immediately north and south of the study area respectively. This arc-accretion model would also be consistent with an easicrly-dipping subduction zone, where the low-K suite was developed in a marginal basin that lay directly to the east of the subducting slab.

The accretionary period started about ca. 830 Ma with emplacement of the calc-alkaline suite and continued to about ca. $635 \mathrm{Ma}$. The steep mylonitic foliation and subhorizontal extension lineation of the BSZ together with syntectonic igneous emplacement suggest that final accretion was achieved through transcurrent movement (Fig. 5.2B; stage 3). The BSZ in this model represents a cryptic suture along which rocks of the low-K suite were tectonically accreted to the calc-alkaline suite and the pre-Pan-African gncissic complex represented by the Baro Domain.

Ultimately there was a collision between a continental fragment represented by the Geba Domain with the proto-African continental margin (Baro Domain) and arc-type rocks of the Birbir Domain. Upon collision, the subducting lithosphere was stripped from the oceanic crust and obducted on to the margin of the Geba Domain (Fig. 5.2B stage 3). Kazmin et al. (i979) and de Wit and Chewaka's (1981) observations of extensive serpentinization along west- dipping fault planes and sheared margins on the Tullu Dimtu rocks sipport the tectonic emplacement of the ophiolite and are consistent with this obduction model. The absence of ophiolitic rocks in the study area, as well as their searcity to the south, is probably related to the depth of plate 
underthrusting (Dewey and Bird, 1972).

The cratonization period (Fig. 5.2C) began after $635 \mathrm{Ma}$ with igneous emplacement and regional metamorphism across the sutured boundary. The mafic intrusions of unit ( $\mathrm{gb}$ ) in the Birbir Domain, directly west of rocks of the calc-alkaline suite, have potentially important implications in this respect. These mildly deformed rocks suggest late-kinematic mafic plutonism. Unfortunately these rocks have not yet been dated nor are their chemical characteristics known. Similar occurrences have been reported north of the study area along strike for over 200 kilometres (Amenti Aioraham, 1984. pers.comm.) associated with rocks similar to those of Group (1). In the absence of more rigorous evidence, they may be tentatively viewed as having $f=-m e d$ in a back-arc environment (stage 4). According to Bruhun el al. (1978). back-arc rifting can be explained in terms of the physical separation of an Andean-type are from a continent. This is followed by diapiric rise of partl! melted mantle material, initiated in response to subduction, together with release of horizontal compressive stresses across the destructive plate boundary causing back-are extension. Cratonization (Fig. 5.2C, stage 5) included emplacement of late- and post-tectonic granites together with minor reorganization of the accreted terrane by horizontal and vertical movements. uplift and erosion following collision.

The study has served to outline part of the tectonic history of the Ethiopian shield and to show that it is consistent with the Pan-African evolution determined elsewhere in the Afro-Arabian shield. The model is nos one of ensialic urogeny, as earlier proposed, but rather of plate convergence with suturing of oceanic and continental crust. 


\section{CHAPTER 6}

\section{PRECAMBRIAN STRATIGRAPHY AND TECTONICS OF ETHIOPIA}

\subsection{GENERAL STATEMENT}

Interpretation of the stratigraphy and tectonic setting of the Precambrian rocks of Ethiopia has been uncertain, mainly because of the lack of systematic dating and scattered nature of the exposures. Kazmin (1971, 1972, 1975) assigned the Precambrian rocks to Lower, Middle and Upper complexes. These divisions were based on the supposition of basement cover relationships and stratigraphic succession from one complex to the next. Kazmin's scheme, which is in general use in Ethiopia, has come under increasing criticism by many workers in the region who have recognized temporal and spatial overlap and transition among his divisions (Warden and Horkel, 1984; Kozyrev et al., 1985).

More critically, the present mapping has revealed that the relationship between some rocks formerly described as basement and cover is rather that of tectonic assembly. Geochemical and isotopic data for the so-called "cover" rocks also imply collision-related calc-alkaline magmatic suites, the development of which may have involved subduction of oceanic lithosphere. The discussion in Chapter 5 calls into yuestion the view that rocks of the Birbir Domain were ensialic mobile belts that formad within older continents.

The recognition of these relationships anong major lithostructural domains, regarded in earlier nomenclature as stratigraphic units, requires a critical review of the whole of the Precambrian stratigraphy of Ethiopia. 
In this chapter a new d: ision of the Precambrian rocks of Ethiopia is attempted.

\subsection{INTRODUCTION}

The greater part of the Ethiopian plateau is underlain by Precambrian rocks succeeded by Mesozoic sedimentary rocks and Tertiary volcanics. The Precambrian rocks are exposed in four separate areas. The northern area includes parts of Eritrea, Gondar and Tigrai administrative regious; the western area, parts of Wollega, Illubabor, Keffa, and Gojjam adminstrative regions; the southern area, parts of Sidamo and Gemu-Gofa adminstrative regions; and the eastern area is in Hararghe adminstrative region (Fig. 1.4). The stratigraphic and tectonic framework has been reviewed by Gilboy (1970), Chater (1971), Kazmin (1971, 1972 b and c, 1975b, 1976). Beyth (1971). Omo River Project Team (1973, 1976), Kazmin et al. (1978, 1979), de

Wit and Chewaka (1981), Davidson (1983), Warden and Horkel (1984), Kozyrev et al. (1985) and in numerous unpublished reports by the geologists of the Ethiopian Institute of Geological Surveys.

Gilboy and Chater divided the Precambrian rocks of southern Ethiopia into three units, referred to as the Lower, Middle and Upper Groups. The transition between the Lower and Middle Groups is gradual, and no major stratigraphic break is present (Chater, 1971). Gilboy described four phases of deformation, and two major regional metamorphic events at ca. 630-680 Ma and ca. 500-550 Ma. Chater recognized four tectonic events and three periods of metamorphic mineral growth in the Lower and Middle Groups. Sedimentar: structures, preserved in rocks of the Upper Group indicate that these 
rocks are the right way up stratigraphically and structurally overlie the Middle Group. Chater suggested that tectonism in the region ceased at least ca. $630 \mathrm{Ma}$ ago, and both Gilboy and Chater concluded that the Precambrian rocks of southern Ethiopia are typical of rocks of the Mozambique Belt elsewhere.

In view of the fact that traditionally the lower-grade rocks have been regarded as deposited unconformably on older gneissic basement, a regional stratigraphy erected on that basis is in common use. Kazmin (1971, 1972) adopted Gilboy and Chater's three-fold division of rocks in southern Ethiopia and extended it to all of the Precambrian rocks of Ethiopia. These divisions are reviewed and assessed below.

\subsubsection{Lower Complex}

The Lower Complex comprises gneisses and migmatites, regarded as reaciivated Archean basement and believed to have a widespread distribution in Sudan, Egypt and possibly Saudi Arabia (Almond, 1969; Kazmin, 1975). They were also considered similar to those found in Kenya. Uganda and Tanzania (Hepworth, 1972. 1979)). The basis for this view was the occurrence of east-west trending relict structures in mafic granulites from southern Ethiopia (Kazmin, 1972), and in the gneisses of upper amphibolite grade in the Geba Domain of western Ethiopia (Kazmin et al. 1979; Mengesha and Seife, unpubished manuscript). The Complex is represented by the Awata, Yavello, Alghe and Konso gneisses in southern Ethiopia and the high-grade metamorphic terranes in western and southwestern Ethiopia. 


\subsubsection{Middle Complex}

Rocks of this complex have been recognized in southern Ethiopia as the Wadera Group and in eastern Ethiopia as the Boye and Soka Groups (Kazmin, 1975b; Kazmin et al., 1978). Kazmin considered the Wadera Group as unconformably overlying the Lower Complex. Chater (197I) and Kozyrev et al. (1985) indicated, however, the absence of such an unconformity between the Yavello gneiss (Kazmin's Lower Complex) and the Wadera Group. According to Kozyrev et al. (1985), the Awata and Yavello gneisses both belong to the Middle Complex.

\subsubsection{Upper Complex}

The rocks assigned to this complex are the Birbir Group. Akobo Domain and ophiolitic rocks of the Tullu Dimtu - Dallati - Yubdo belt in western Ethiopia (Kazmin et al., 1978); the Awata and Mormora groups of southern Ethiopia (Kozyrev et al., 1985); and the Tsaliet and Tambien Groups in northern Ethiopia (Beyth, 1971). The Birbir Domain of the Geotraverse area forms part of this complex. In southern Ethiopia the interface between the Middle and Upper Complex is described as a tectonic contact (Kozyrev et al., 1985).

\subsubsection{Other Divisions: Omo River Project}

A large area in southwestern Ethiopia, as far north as the southern edge of the Gore - Gambella area, was described in geological maps and reports prepared by the Omo River Project (Omo River Project Team, 1073. 1976; Davidson, 1983). Davidson (1983) recognized three domains on the basis of marked lithological, metamorphic and structural contrasts; these are 
referred to as the Hamar, Akobo and Surma domains. Two major groups of rocks were identified, one probably much older than the other. Rocks of the Hamar Domain, part of the older group, have been metamorphosed twice and were intruded by plutonic rocks both before and after the first metamorphic cvent. Younger sedimentary and volcanic rocks of the Akobo Domain were deposited west of the Hamar domain and subsequently deformed and thrust toward the west, prior to the youngest period of metamorphic activity.

During the second metamorphic event, gneissic rocks of the Surma Domain were juxtaposed against rocks of both the Hamar Domain and the relatively lowgrade Akobo Domain along a major shear belt, the Surma mylonite zone.

\subsection{LITHOSTRUCTURAL UNITS}

Lithological, metamorphic and structural discontinuities in the Precambrian rocks of Ethiopia indicate that these rocks represent difierent lithostructural units. A new lithostructural subdivision and nomenclature are proposed here, based on the present mapping and a review of previously published information (Kazmin et al., 1979; de Wit and Chewaka, 1981; Warden, 1982; Davidson, 1983; Warden and Horkel, 1984; Kozyrev et al. 1985). A geological sketch map of the distribution of Precambrian rocks of Ethiopia, with the proposed names, is given in Figure 6.1. A generalized stratigraphic division, applicable only to western Ethiopia, and based mainly on the Gore - Gambella Geotraverse, is given in Table 6.1. For comparative purposes the earlier divisions are indicated in the text where appropriate, together with the newly proposed nomenclature. 


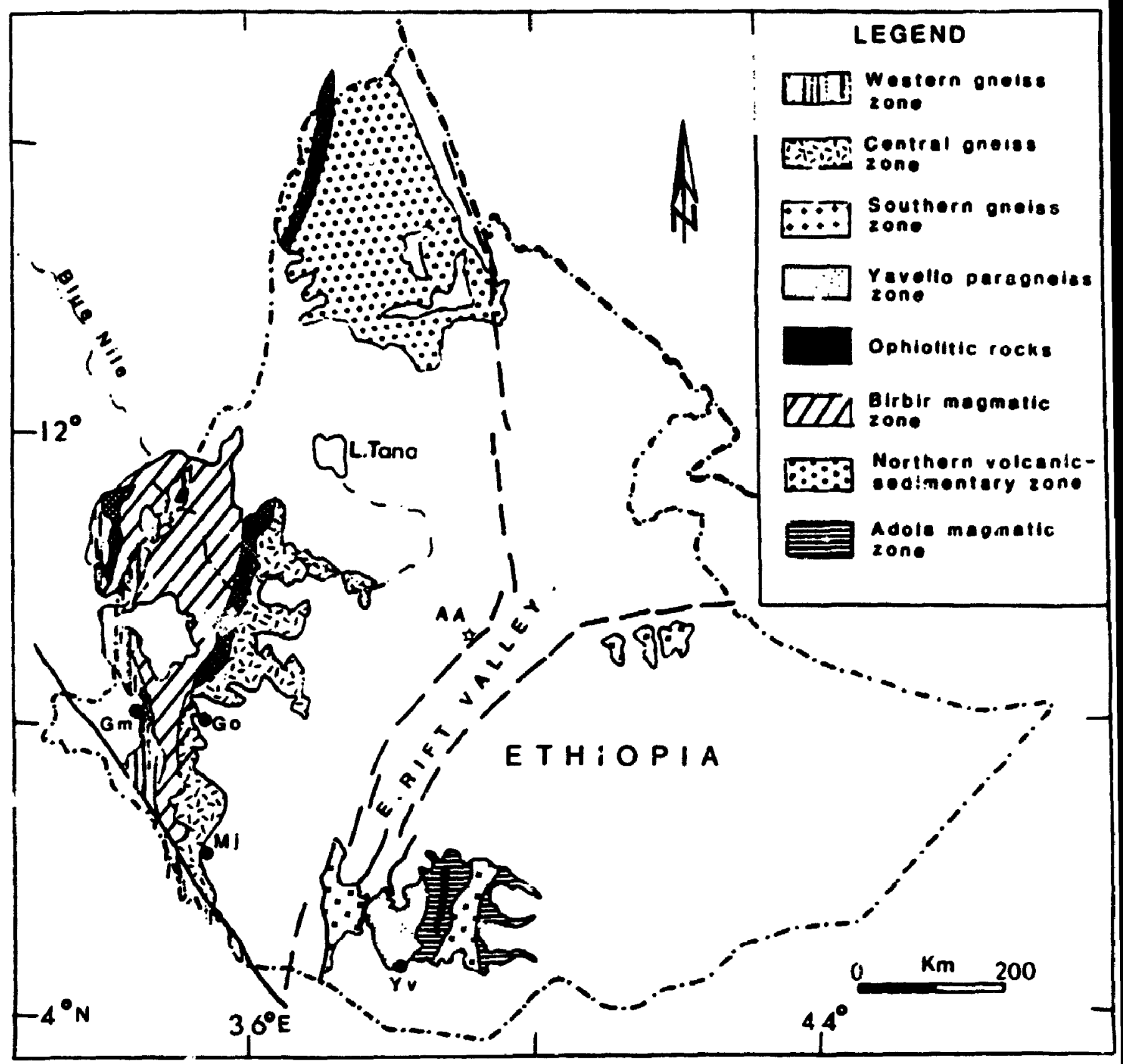

Figure 6.1: Sketch map of the Precambrian rocks of Ethiopia showing the distribution of the proposed lithostructural units. 

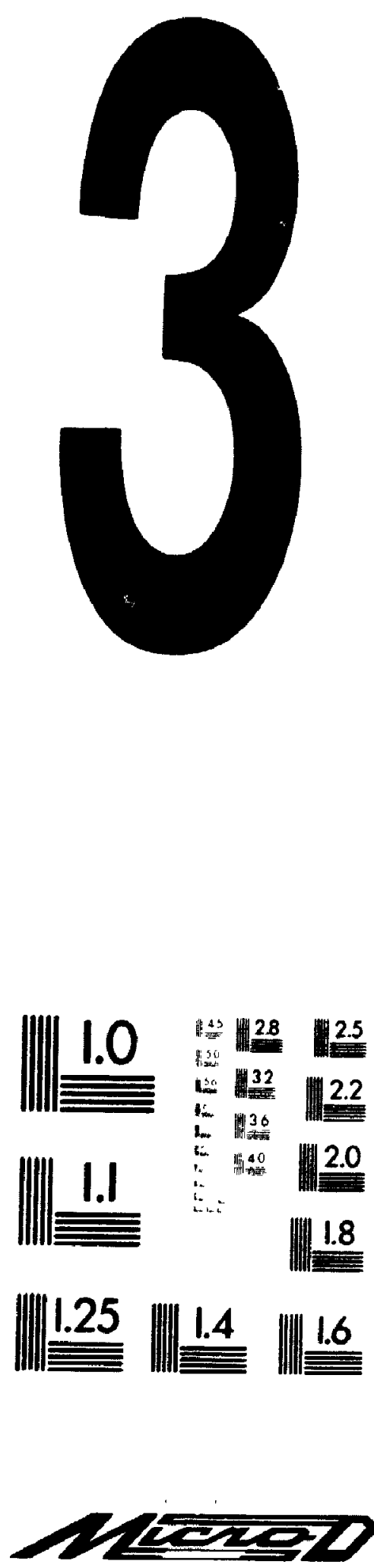
Table 6.1: IDEALIZED LITHOSTRATIGRAPHIC SEQUENCE IN WESTERN ETHIOPIA

Alluvium

QUATERNARY

1- Central-type volcanoes

(mainly basalt, trachyte \& phonolite)

TERTIARY

2- Fissural basalts

UNCONFORMITY

Birbir magmatic zone

qlkali-feldspar granite plutons, aplites

\& pegmatites (late- to post-kincmatic)

$550-570 \mathrm{Ma}$

maric plutons, dykes and sills

(latc-kincmatic gabbro \& hornblenditc)

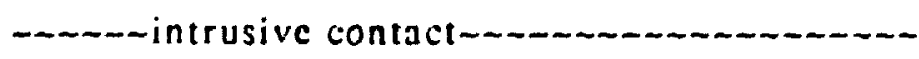

calc-alkaline intrusive rocks

(pre-kinematic; predominantly quartz

diorite \& granodiorite)

calc-alkaline volcanics \& volcanogenic

sediments (mainly andesite and minor

silicic flow, turbiditc \& volcaniclastic rocks

$810-830 \mathrm{MIa}$

LATE

PROTEROZOIC

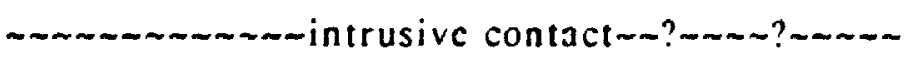

low-K intrusive rocks

(predominantly gabbro \& tonalite)

Tullu Dimtu ophiolitic rocks

uliramafic rock, gabbro, pillowed basalt

turbiditic sediments, chert \& marblc

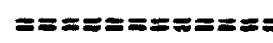

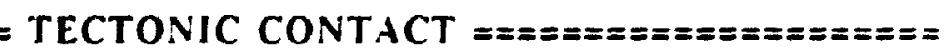

leucogranite shects

I.ATE

clastic sediments

(quartz-muscovite schist, quartzitc and

PROTEROZOIS

conglomerate layers)

OR OLDER (?)

paragneisscs, schists \& amphibolitc

(sillimanite-garnet schist and gnciss, and subordinatc calc-silicatc rocks)

$\sim \sim \sim \sim \sim$ probable unconformity $\sim-? \sim \sim \sim \sim \sim \sim$

Western gneiss zone

quartzo feldspathic gnciss with amphibolite bands and minor magnetite bcaring quartzite layers

laycred and flaggy hornblendebiotite gneiss, migmatite
Central gneiss zone

heterogeneous ortho- \& paragneiss, migmatitc 


\subsubsection{Western gneiss zone (WGZ)}

In parts of western and southwestern Ethiopia a high-grade gneissic complex, that contains the Baro Domain of the Geotraverse area and is correlated with rocks to the south in the Surma Domain of Davidson (1983), is defined as the Western gneiss zone. The Baro Domain consists of biotite ard hornblende gncisses, generally well-layered, with subordinate amphibolite and quartzite. It is similar to the Grey Gneiss Group of the Bayuda desert in the north-central Sudan (El-Nadi, 1987). A strong lithological similarity exists between the Baro and the Surma Domain to the south. The latter is separated by a major NW- trending shear zone from lower-grade rocks of the Akobo Domain to the east, in the same way that the Baro Domain is separated from the Birbir Domain rocks by the N-S trending Birbir Shear Zone. Mylonitic foliation is developed along the eastern contacts of both the Surma and Baro domains. Across both transcurrent fault systems, there is an abrupt change in metamorphic grade from upper amphibolite facies to epidote amphibolite facies grade of metamorphism (Davidson, 1983; Chapter 2).

The Baro Domain is characterized by widespread leucogranite sheets, such as the Baro leucogranite, that are strongly deformed into upright open folds with north - south axial traces and sub-horizontal axes. The sheets are interpreted as anatectic granites (see Chapter 2), although some may represent sills intruded parallel to gneissic layering. Davidson (1983) interpreted the granite sheets as highly-flattened slices, each associated with a folded, east-dipping thrust plane.

On the eastern edge of the Baro Domain, a wedge of high-grade 
metasedimentary schists and gneisses occurs. These rocks include pelites. calc-silicates and minor psammites, best exposed near Bonga. To the north, near Dembi Dollo, these rocks are layered, garnet-bearing, biotite gneisses with minor interlayers of quartzite. These rocks may represent shelf sediments, deposited along a continental margin.

\subsubsection{Central gneiss zone (CGZ)}

Rocks of the Geba Domain and the western half of the Hamar Domain, as well as the Didessa gneisses in west - central Ethiopia, make up the Central gneiss zone (Fig. 6.1). The CGZ occupies the area northeast of Lake Turkana and east of the Omo River, where it comprises the Hamar Domain of Davidson (1983) and its northward continuation along the Geba and Didessa valleys. The Hamar Domain consists of gneisses and granulites of both igneous and sedimentary origin, partly migmatized and cut by a suite of younger plutonic rocks (Davidson, 1983). Kazmin et al. (1979) described the gneisses of the Geba and Didessa valleys as biotite and amphibole - biotite banded gneisses, locally garnetiferous, that grade into homogeneous grano- dioritic and granitic rocks.

In the Geba valley, transposition of east-west, map-seale, recumbent isoclinal folds into north-south trending isoclinal folds has been reported (Kazmin et al., 1979; Mengesha and Seife, unpublished manuscript). The eastwest structures are similar to those found in the Archean East African cratons (Spooner et al. 1970; Leggo, 1971) that form the basement in Kenya, Tanzania, NE Uganda and SE Sudan (Kazmin, 1976; Vail, 1976; Almond, 1980). Kazmin also noted the abundance of large, late-tectonic granite bodies in 
the northern part of CGZ and the extensive migmatization in the southern part of the CGZ. He attributed the distribution of these rocks to uplift and erosion of progressively more deeply buried and metamorphosed rocks southwards.

\subsubsection{Southern gnelss zone (SGZ)}

This zone contains the Alghe and Konso gneisses that mainly occur in Sidamo and Gemu Gofa administrative regions of southern Ethiopia, and the inliers of Dengego gneiss in Hararghe administrative region. The Alghe gneiss consists of layered biotite - hornblende gneiss and migmatite; it is structurally overlain by the A wata mafic gneiss (Warden, 1982; Warden and Horkel, 1984). Chater (1971) described the Alghe gneisses in Megado region, referred to as the Lower Group, as forming a broad domal core that represents an east-west trending fold system, reworked ty the Pan-African event that produced north-south structures. Warden and Horkel (1984) supported Chater's view, and considered that the Alghe gneiss of the SGZ is the lowest structural unit in southern Ethiopia.

The Konso gneisses are made up mainly of granulites with subordinate amphibolite facies rocks of both sedimentary and igneous origin. The granulites and the amphibolite grade rocks within the SGZ are supposedly separated by Pan-African isograds, that cut across primary layering (Omo River Project Team, 1973; Davidson, 1983). The reported structural continuity in these rocks indicates that the isograds represent different structural levels in reactivated crust. Kazmin (1975b) arbitrarily assigned the granulites to his lowest stratigraphic unit, the Lower Complex. 
The Dengego gneiss mainly ronsists of migmatites; the relationship between these rocks and those of the Alghe and Konso gneisses is not clear.

\subsubsection{Yavello paragneiss zone (YPZ)}

The Yavello paragneiss zone represents the Awata, Yavello and Burji gneisses in addition to the Wadera Group of the Middle Cumplex of Kazmin (1975b, 1978b). Kozyrev et al. (1985) subdivided rocks of the YPZ into the Awala and Mormora groups. According to Kozyrev et al., rocks of the Awata Group lie unconformably on the Alghe gneiss of the SGZ in one locality (Awata River), but is faulted against it elsewhere. The Awata Group is represented by the Bora and Buluka Formations, that contain mainly amphibole and biotite-amphibole gneisses. The Mormora Group is represented by the Zembaba, Aflata and Kenticha Formations in ascending stratigraphic order. The Zembaba Formation (equivalent to Kazmin's Wadera Group) consists of quartzofeldspathic rocks with minor intercalations of biotite-hornblende gneiss and marble. The Aflata Formation consists of biotite gneisses alternating with amphibolites and thin beds of marble in the upper part. The Kenticha Formation is characterized by graphitic and micaceous schists and metapelites, containing kyanite, staurolite and garnet. The prevailing psammites and conglomerates have well-preserved sedimentary structures such as cross bedding and ripple marks clearly indicating a continentallyderived, metaclastic succession (Gilboy, 1970; Chater, 1971).

Although adequate structural constraints are lacking, Warden and Horkel (1984) suggested that the YPZ rocks were subaerially deposited in a blockfaulted graben system underlain by rocks of the SGZ. Contact relations 
between the YPZ and the structurally underlying rocks of the SGZ are masked by migmatization and intense shearing in the basal part of the Awata and Yavello gneisses. In the absence of any marked stratigraphic break, distinction between the YPZ and the SGZ is made on contrasting lithologic types and moderate changes in mriamorphic grade, from middle amphibolite to upper amphibolite and granulite grade respectively.

A Rb-Sr whole-rock isochron from a phyllite within the YPZ has yielded the oldest date in Ethiopia: $1030+/-40 \mathrm{Ma}$ (Chater, 1971), which places a minimum age on the time of sedimentation.

In castern Ethiopia, lithologically similar occurrences to those of the Mormora Group, known as the Boye and Soka Groups (Kazmin, 1975), appear to be a northward continuation of rocks of the YPZ. The Boye Group consists of quartzite, arkose, graphitic and stromatolitic marble that are overlain by the Soka Group of graphite, talc, and chlorite schists as well as phyllite.

\subsubsection{Tullu Dimtu ophiolitic rocks}

The Tullu Dimtu-Dallati-Yubdo mafic/ultramafic rocks of western Ethiopia are thought to be ophiolitic in nature (Kazmin, 1976; de Wit and Aguma, 1977; Shackleton, 1986). These are probably equivalent to those found in northern Ethiopia along the Baraka lineament, and to the south in subdomain 4 of the Akobo Domain in the Omo River project area (de Wit and Chewaka, 1981; Davidson, 1983).

The Tullu Dimtu ophiolitic rocks form a belt $10-15 \mathrm{~km}$ wide and $120 \mathrm{~km}$ long belt (Kazmin, 1976; de Wit and Aguma, 15 77) containing dunite, pyroxenite and gabbro with associated pillow lavas and breccia overlain by 
chert, limestone and black shale. The metasedimentary rocks are interlayered with thick units of mafic metavolcanics. Sheeted-dyke complexes rep.orted from the area look like vertical partings or fractures in metamorphosed mafic flows. Kazmin (1976) pointed out that the belt consists of numerous tectonic slabs separated by steep, westerly-dipping thrusts (overthrust to the east) and narrow shear zones. Davidson (1983) described elongate masses, lenses and slivers of mafic/ultramafic rocks in the Akobo and Alanga basins in Illubabor adminstrative region.

\subsubsection{Birbir magmatic zone (BMZ)}

Rocks of this zone occupy western and southwestern Ethiopia and are probably traceable northwards into the Butana and southern Red Sea Hills volcano-sedimentary terranes of Sudan. These are in turn traceable into the Asir volcano-sedimentary terrane in Arabia (the equivalent of the Jeddah terrane). The BMZ consists of cale - alkaline volcanic and plutonic rocks, and associated sedimentary rocks equivalent to the Birbir Group of Kazmin (1976, 1978). In s(,uthwestern Ethiopia, rocks of this zone can be traced as far south as latitude $6^{\circ} \mathrm{N}$, where they form subdomains 1 and 3 of the Akobo Domain (Davidson, 1983). The zone extends to the north across the GoreGambella Geotraverse area, where plutonic rocks make up three-quarters of the rocks in the area. The present study provides a basis for sub-dividing the BMZ into four types using geochemistry and geochronology of the Llutonic rocks.

The first consists of strongly-deformed gabbro, diorite, tonalite and granodiorite, referred to as the low-K suite; the second comprises quartz 
diorite to granodiorite and minor granite assigned to the calc-alkaline suite. According to the present mapping and also further north (Kazmin et al., 1979), rocks associated with the low-K suite include metamorphosed andesitic to rhyolitic volcanics, wacke, pelite, and $m \quad$ intercalations of coarse volcaniclastic rock, Fe-rich quartzite, intraformational conglomerate, marble and chert. In the preceding chapters, it is proposed that the low-K suite formed on oceanic crust in an island arc environment.

The strongly-deformed, elongate bodies of the calc-alkaline suite have been attributed on chemical and isotopic grounds to continental margin arctype magmatism. The metasedimentary rocks associated with the group include wackes, pelites, volcaniclastic rocks and subordinate marble and chert.

The third group of plutonic bodies, the alkali-feldspar granite suite, is late- to post-kinematic, while the fourth, and least known group of plutonic rocks, on the west side of the $B M Z$, is characterized by massive to slightly deformed gabbro, diorite and hornblendite in the Geotraverse area. Undeformed, circular gabbros intruding abundant mafic volcanics, interlayered graphitic schist and quartzite were described to the north along strike (Kazmin et al., 1979, Amenti Abraham, pers.comm., 1984). These seemingly late-kinematic gabbros imply that mafic magmatism was repeated late in the tectonic evolution of the BMZ, perhaps in an episode of back-arc spreading.

\subsubsection{Northern volcanic-sedimentary terrane (NVST)}

The northern volcanic-sedimentary terrane (NVST) occupies a large part of north and northeastern Ethiopia, in Tigray and Eritrea administrative 
regions. The NVST is traceable into the full width of the Asir south (Abha) and Asir east volcanic-sedimentary terranes (Stoesser and Camp, 1985) along the Red Sea in Arabia (Fig. 1.2). The NVST consists of the Tsaliet Group that grades into rocks of the Tambien Group, which is in turn unconformably overlain by the Didikama, Shiraro and Matheos Formations (Beyth, 1971. Morton, 1975).

The Tsaliet Group consists of meta-andesite and tuff, tuffaceous slate, greywacke and rhyolitic breccia. Morton (1975) described the Tsalict Group of the Enticho area as a succession of interbedded mudstone and intraformational conglomerate, greywacke, limestone and volcanic and pyroclastic rocks. Pillow structures in voleanies and sedimentary structures such as ripple marks have been reported. Morton also interpreted the Tsaliet Group as indicating deposition within both marine and subacrial environments. Syn-and post-tectonic plutons, that range from ultrabasic to granitic in composition, cut the Group. K/Ar dates of $690+/-4 \mathrm{Ma}$ (Miller et al., 1967), and 800 Ma (Metal Mining Agency of Japan, 1974) were obtained from post-tectonic granites and granodiorites.

The Tambien Group consists of slate and dolomitic and algal limestonc. The Didikama, Shiraro and Matheos Formations comprise a succ. -ion of saccharoidal, stromatolitic limestones that alternate with thin beds of clastic sedimentary rocks.

\subsubsection{Adola magmatic zone (AMZ)}

The Adola magmatic zone occurs in southern Ethiopia and corresponds to the "Upper Group" of Gilboy and Chater (1970), later described as the Adola 
Group that consists of the Chakata and Finkilcha Formations and Kajimiti beds (Kozyrev et al., 1985). The Chakata Formation makes up the lower part of the Adola Group and consists of strongly sheared, discontinuous ultramafic lenses associated with amphibolite, schist, mafic plutons and volcanics showing relict pillow structures, considered parts of an ophiolite complex. The upper part consists of graphitic phyllite and argillaceous rocks forming the Finkilcha Formation. Rocks of the Chakata Formation can be divided into narrow, parallel tectonic zones, considered to be easterly-thrusted nappes (Kazmin, 1976). The Kajimiti beds lie unconformably on rocks of the Chakata and Finkilcha Formations and consist of psammite, biotite schist and calcareous sedimentary rocks. The sedimentary rocks of the Finkilcha Formation and Kajimiti beds have been interpreted as products of sedimentation within the Megado graben-syncline (Kozyrev et al., 1985).

$\mathrm{Rb} / \mathrm{Sr}$ whole-rock isochron dates of $680+/-30,450+/-10$ and $505+/-10$ Ma Ma (Gilboy, 1970; Chater, 1971)) were reported from post-tectonic granites intruded into the $A M Z$.

\subsection{SUMMARY}

The lithostructural units described above appear to be representative of both the pre- Pan-African crust and Pan-African rocks. The portion of the pre- Pan-African crust reactivated during the late Proterozoic compris : the Mozambique Belt in east Africa. The Mozambique Belt has a complex history of superposed deformation and metamorphism, and reworked rocks as old as Archean have been identified within it (Kroner, 1977; Almond, 1982; 
Shackleton, 1986). The Pan-African rocks, on the other hand, exhibit a more restricted set of events and have evolved mainly in the interval ca. 1000$550 \mathrm{Ma}$ (Greenwood et al., 1976; Ries et al., 1985). This study as well as more recent publications (e.s. de Wit and Chewaka. 1981; Kozyrev et a1., 1985; Shackleton, 1986) have supported an accretionary history more consistent with the emerging views concerning the surrounding region. Thus the eight lithostuctural units described above may be grouped into iwo broad categorics:

\subsubsection{Reactivated Pre- Pan-African rocks}

The reactivated pre- Pan-African rocks of Ethiopia include the Baro and Geba Domains of the Geotraverse and comprise the Western. Central, and Southern gneiss zones. These are high-grade polycyclic rocks with more than one generation of metamorphism and structure (Gilboy, 1970; Chater, 1971: Davidson, 1983; Kozyrev et al. 1985). Relict east-west - trending recumbent isoclinal folds are preserved in the high-grade gneissic terranes of western (Kazmin et al. 1978) and southern Ethiopia (Chater, 1971; Warden, 1984; Warden and Horkel, 1984). In western Ethiopia, along the frontier zone between Ethiopia and the Sudan, the presence of large east-west - Irending folds is reported from satellite imagery (Warden and Horkel, 1984). These folds represent probable remnants of pre- Pan-African basement structure. similar to those described from the besement rocks of Kenya and Uganda (Hepworth, 1972, 1979). The Pan-African event, however, reworked and largely obliterated the east-west structures. This event superimposed foliation and gneissic layering on earlier structures and these strike NNE to NNW. 


\subsubsection{Pan-African recks}

Rocks of Pan-African age within Ethiopia include ophiolitic rocks, calc-alkaline volcanic and plutonic units and associated sediments. In Ethiopia, the Pan-African rocks include the Yavello paragaeiss zone, the Tullu Dimtu ophiolitic rocks, the Birbir magmatic zone, the northern volcanic-sedimentary terrane and the Adola magmatic zone. In western Ethiopia, these rocks have been considered as wedges of oceanic crust associated with rifted zones, early igneous activity and later crustal thickening during ocean closure and collision (Kazmin et al., 1978; A yalew et al., 1987). The lithologic association, grade of metamorphism and style of deformation are similar to those described in other NE African and Arabian Pan-African rocks. These can be traced directly in a palinspastic reconstruction of the NE African-Arabian Shield, into two branching systems extending from within Ethiopia (Vail, 1985; Fig. 5.1). The eastern belt, comprising the northern volcanic-sedimentary terrane (NVST) and possibly the Adola magmatic zone (AMZ) to the south, joins the Asir south (Abha) and Asir east terranes within the Arabian peninsula. The western belt of the Birbir magmatic zone (BMZ) is traceable into the southern Red Sea Hills and the Jeddah terrane or Asir volcano-sedimentary terranes in Sudan and Saudi Arabia respectively. This extrapolation suggests that the two diserete belts each result from more than one phase of island arc formation.

\subsection{RELATIONSHIP OF PRE- PAN-AFRICAN AND PAN-AFRICAN ROCKS IN WESTERN ETHIOPIA \\ There seems little doubt that early east-west trending structures in the Geba gneisses and Konso granulites of the CGZ (Teferra and Berhe,}


unpublished; Kazmin, 1975b) are overprinted by north-south - trending structures of Fan-A frican age. South of the Western Ethiopian Shicld similar structures have been documente, in rocks of the known Mozambique Belt, that are known to be older than late Proterozoic (for example: Sanders, 1965: Hepworth, 1972; Shackleton, 1986). In the foreland zone to the west of the Mozambique Belt, the north-south structures are absent anc rocks that have been dated yield Archean and early Proterozoic ages. Rocks of WGZ and CGZ have yet to be dated; however, they contain mineral assemblages typical of high temperature and medium pressure metamorphism. Most isotope systematics are casily disturbed under these physical conditions, so it is difficult to establish the true age of these rocks by conventional methods. Older ages may have been obliterated or distorted by the Pan-Africa.a event.

The chemical character of rocks of the Birbir magmatic zone and its association with ophiolitic rocks imply that it originated through both ensimatic and ensialic processes. These rocks appear to be disposed in a major steeply-dipping ductile transcurrent shear zone interpreted as a plate boundary. This boundary, marked by the presence of ophiolitic rocks, is continuous as far north as Saudi Arabia and defines a suture between prePan-African rocks and Pan-African rocks. The subduction model that has been proposed in Chapter $S$ clearly explains the tectonic juxtaposition of lowirgrade and high-grade rocks in western Ethiopia. The model of tectonic assembly virtually negates Kazmin's stratigraphic model based on basement cover relationships. Much more geochronological work will be needed, however, in order to rigorously test this new tectonic model. 


\section{CHAPTER 7}

\section{CONCLUSIONS}

\subsection{GEOLOGY}

The Gore-Gambella area straddles the boundary between three geologic domains. The Baro and Geba domains consist of heterogeneous ortho- and paragneisses and migmatites while the Birbir domain consists of metasedimentary and calc-alkaline volcanic and plutonic rocks. There is an abrupt increase in metamorphic grade across the domain boundaries. Ma: imum P-T conditions of metamorphism inferred from rocks of the Baro and Birbir domains are $6.5 \mathrm{~kb}$, $700^{\circ} \mathrm{C}$ and $3.5-4 \mathrm{~kb}, 525-545^{\circ} \mathrm{C}$ respectively.

Field relations of the seven plutonic units studied suggest three groups: 1) pre- 10 syn-kinematic mafic and intermedinte intrusive complex, 2) syn-kinematic leucogranite sheets, and 3) late to post-kinematic alkalifeldspar granite. Rocks of Group (1) occupy the Birbir Domain, and are metamorphosed and deformed to variable degrees within a major north-south, ductile, transcurrent fault system, the Birbir Shear Zone (BSZ). Deformation is most extreme in rocks of Group (1). Protomylonites and mylonites alternate with narrow, heterogeneous mylonitic units and show steep to vertical mylonitic foliation and sub-horizontal stretching lineation. Group (2) rocks are strongly-deformed, elongate plutons with long axes and internal foliation parallel to the foliation found in the enclosing gneissic rocks of the Baro Domain. Pli tons of Group (3) are more equidimensional, discordant and generally undeformed; they have intruded the western Birbir and Birbir/Baro boundary zone. 


\subsection{CHEMISTRY}

Group (1) rocks are div:ded into two genetically distinct suites, a low-K gabbro-tonalite suite and calc-alkaline suite that ranges from diorite to granodiorite. REE in the low-K suite show low absolute abundance (4075ppm), no Eu anomaly (Eu/Sm:0.31-0.32) and La/Lu(cn)=5.3. The calc-alkaline suite has high absolute REE abundance (99-121ppm), a slight Eu anomaly (Eu/Sm:0.23-0.27) and $\mathrm{La} / \mathrm{Lu}(\mathrm{cn})=5.1-7.5 . \mathrm{Rb} / \mathrm{Sr}$ ratios for the low-K suite range from 0.01 to 0.04 whereas for the calc alkaline suite they are significantly higher and range from 0.11 to 0.17 . On the basis of trace element data (Hf, $\mathrm{Nb}, \mathrm{Rb}, \mathrm{Ta}, \mathrm{Y}$ and $\mathrm{Yb}$ ) Group (1) rocks are considered to be the product of magmatic are activity, whereas Groups (2) and (3) reflect intraplate activity. Major and trace element data also suggest that the low. $K$ suite is oceanic in affinity, whereas the calc-alkaline suite resembles the continental margin type.

Major and some trace element data for samples from groups (2) and (-3) are very similar but the two groups have distinct REE patterns. Group (2) plutonic units are products of large scale anatexis, resulting from crustal thickening along the eastern part of the Baro domain. Group (3) rocks are thought to have been formed by partial melting of the evolved arc, related to post-collisional uplift.

\subsection{GEOCHRONOLOGY}

Five U-Pb zircon and four $\mathrm{Rb}-\mathrm{Sr}$ isochron dates constrain the ages of the plutons and their subsequent history. The data show plutonic activity between 830 and $540 \mathrm{Ma}$, similar to the time span established for the Pan- 
African rocks of the Southern Red Sea Hills of the Sudan and the Jeddah

terrane of Saudi Arabia. U-Pb zircon ages of $828+/-5$ and $2 / 4+/-2 \mathrm{Ma}$, obtained from Group (1) rocks, date the time of their emplacement. One of these plutons, the Goma pluton, also yielded a whole-rock Rb-Sr isochron date of $759+/-18 \mathrm{Ma}$. Granite sheets of Group (2) within the high-8rade Baro domain, that are believed to be anatectic in origin, were dated by $\mathrm{U}-\mathrm{Pb}$ at $782+/-15 \mathrm{Ma}$. The 780-760 Ma event is interpreted as the period of PanAfrican regional metamorphism in western Ethiopia. This event also correlates with the age of low-grade metamorphism of arc-related rocks elsewhere in NE Africa. The Birbir domain, therefore, represents a southward extension of the Pan-African crust of NE Africa and Arabia. Other reset RbSr whole rock isochrons that cluster around $635+/-8$ Ma provide evidence of significant isotopic homogenization, probably associated with major transcurrent movement parallel to a plate margin undergoing obiique collision. A U-Pb lower intercept age of $582 \mathrm{Ma}$ from rocks of Group (2) denotes a second high-grade metamorphic event and correlates with the age of the Mozambiquian amphibolite facies metamorphism in NW Kenya. The Baro domain is here interpreted as a continental margin to the Mozambiquian basement system to which juvenile crust accreted.

U-Pb ages of $571+/ .5$ and $550+/-10 \mathrm{Ma}$ were obtained from the Group (3) late- to post-kinematic plutons. Rb-Sr biotite dates from Group (1) prekinematic plutons indicate resetting of mineral systems until about $540 \mathrm{Ma}$ ago.

\subsection{CONCLUDING NOTES}

The principal geolneic features of western Ethiopia are consistent with 
a plate tectonic mode of development. The geology, chemistry and isotopic data presented above show distinct and separate episodes of plutonism. Chemical characteristics of plutons from the Birbir domain suggest a subduction model for magma generation. The presence of ophiolitic rucks in :he Tullu Dimtu belt immediately north of the study area supports such a model. The inferred tectonic evolution of the area is summarized below:

1. The chemical and isotopic characteristics of rocks of the Birbir Domain imply both ensimatic and ensialic processes of origin. The Birbir Domain was developed and aggregated through processes of magmatism, sedimentation and tectonism that accompanied closure of an ocean basin.

2- The pe.aluminous plutonic units are restricted to the Baro Domain that may be related to crustal thickening and large scale anatexis along a tecto ically active continental margin.

3- The Birbir Shear Zone (BSZ) is evidence for major translation during tectonic assembly of the Birbir and Baro domains. The transcurrent movement on the BSZ was initiated as dextral displacement, possibly parallel to an active plate margin undergoing oblique subduction, and subsequently changed to sinistral movement during the terminal stages of collision. The BSZ represents a mylonitic cryptic suture. The suture hetween the Geba and Birbir domains is marked to the north of the study area by the Tullu Dimtu ophiolitic rocks. 
4- A culminating event at about $580 \mathrm{Ma}$, probably a continental collision, generated high-grade metamorphism and granitic plutonism during 580-550 Ma.

In conclusion, the recognition in this study of contrasting genetic types of plutonic rocks, represented by Group (1) on one hand and Group (2) on the other, and the identification of a wide zone of intervening mylonites lends support to an hypothesis for the existence of two distinct rock suites. The association of ophiolitic rocks (occurring north and south of the Geotraverse area but not mapped during this study) and the primitive Sr isotope ratios indicate the close association of oceanic crust in the region at the time. Rocks of the Birbir magmatic zone were apparently accreted to the eastern margin of the pre- Pan-African crust during a relatively long span of time, ca. $830-630 \mathrm{Ma}$. The zone presumably represents one or more suspect terranes, but the extent of the individual terranes and the processes through which they were accreted are essentially unknown. Considerable progress has been made in understanding the nature of the contact between the lower grade and high-grade rocks in western Ethiopia. There are no data yet that define the original age of the high-grade metamorphic rocks, seen in the Baro and Geba domains and elsewhere in Ethiopia, that appear to be continental erust to which the are rocks have been accreted. Further chemical and isotopic studies of the plutonic and volcanic rocks, detailed geochronologic studies of selected critical samples, and detailed analysis of structural and metamorphic history are required to test the tectonic model in its entirety. 


\section{REFERENCES}

Abbey, S. 1977. Studies in standard samples for use in the sencral analysis of silicate rocks and minerals. Geological Survey of Canada, Paper 77-34, 31 p.

Abdel Monem, A., and Hurley, P.M. 1979. U-Pb dating of zircons from psammitic gneisses, Wadi Abu Rosheid - Wadi Sikait area, Egypt. Proceedings of a symposium convened by Ahmad M.S. Al. Shanti. Institute of Applied Geology, Jeddah. 3, pp. 265-270.

Allègre, C.J., and Ben Othman, D. 1980. Nd - Sr isotopic relationship in granitoid rocks and continental crust development: a chemical approach to orogenesis. Nature, 286, pp. 335-342.

Almond, D.C. 1969. Structure and metamorphism of the basement complex of northeast Uganda. Overseas Geology and Mineral Resources, 10 , pp. $146-153$.

Almond, D.C., 1980. Precambrian events at Sabaloka, near Khartoum. and their significance in the chronology of the basement complex of north-east Africa. Precambrian Research, 13. pp. 43-62.

Almond, D.C., 1982. New ideas on the geological history of the basement complex of NE Sudan. Notes and Records, Geology and Mineral Resources, Sudan, 59, pp. 106-136.

Almond, D.C., 1984. The concepts of "Pan-African Episode" and "Mozambique Belt" in relation to the geology of east and north-cast Africa. In: A. Al Shanti (ed.). Evolution and Mineralization of the Arabian-Nubian Shield. Institute of Applied Geology Bulletin. Pergamon Press, Jeddah. 6, pp. 7187.

Al Shanti, A.M.S. 1979. The aims, objectives and scope of IGCP Project 164 "Pan-African crustal evolution in the Arabian-Nubian Shield". Newsletter, IGCP Project 164, G. Cooray (ed.). 2. pp. 9-13.

Al Shanti, A.M.S., and Gass, I.G. 1983. The upper Proterozoic ophiolite melange zones of the easternmost Arabian Shicld. Journal of the Geological Society of London, 140, pp. 867. 876. 
Al Shanti, A.M.S., and Mitchell, A.H.G. 1976. Late Precambrian subduction and collision in the Al Amar - Idsas region, Arabian Shield, Kingdom of Saudi Arabia. Tectonophysics, 30. pp. 41-47.

Anderson, J.L., and Cullers, R.L. 1978. Geochemistry and evolution of the Wolf River batholitih, a Late Precambrian rapakivi massif in north Wisconsin, USA. Precambrian Research, 7, pp. 287 324.

Arth, J.G., and Barker, F. 1976. Rare earth partitioning between hornblende and dacitic liquid and implication for the genesis of trondhjemitic - tonalitic magmas. Geology, 4, pp. 534-536.

Atherton, M.P., McCourt, W.J., Sanderson, L.M., and Taylor, W.P., 1979. The geochemical character of the segmented Peruvian coastal batholith and associated volcanics. In: Atherton, M.P. and Tarney, J. (eds.). Origin of Granitic Batholiths Geochemical Evidence. Shiva publishing, UK. pp. 65-75.

Augustithis, S.S. 1966. Micrographic (granophyric) textures in quartzitic pebbles of the granitised conglomerate of Buri Rashitcha, Ula Ulo, Adolo district, southern Ethiopia. Contributions to Mineralogy and Petrology, 13, 75-82.

Ayalew, T., Bell, K. and Moore, J.M. 1987. Magmatic arc intrusive complexes in the Birbir Domain, western Ethiopia. In: $G$. Matheis and H. Schandelmeier, (eds.), Current Research in

African Earth Sciences. Balkema, Rotterdam/Boston. pp. 113116.

Baines, T.V., and Duesing, C.M. 1966. Report on specimens from Adola, Yubdo, Daletti and Adi Rassi. (unpublished report).

Ball, R.F. 1971. Ula Ulo and Kilta, Geology and Geochemistry. International Nickel Company. (unpublished report)

Barker, F. 1979. Trondhjemite - definition, environment and hypothesis of origin. In: Trondhjemites, Dacites, and Related Rocks. Barker. F. (ed,), Elsevier, Amsterdam. pp. 2-5.

Barker, F., and Arth, J.G. 1976. Generation of trondhjemitic tonalitic liquids and Archaean bimodal trondhjemite-basalt suites. Geology, 4, pp. 596-600.

Bateman, P.C. and Dodge, F.C.W. 1970. Variations of major chemical constituents across the central Sierra Nevada batholith. Geological Society of America Bulletin, 81, $409-420$. 
Bell, K., and Dodson, M.H. 1981. The geochronology of the Tanzanian Shisld. Journal of Geology, 89, pp. 109-128.

Bell, K., and Blenkinsop. J. 1978. Reset Rb/Sr whole-rock systems and chemical control. Nature, 273, pp. 532-34.

Bell, K., Blenkinsop, J., Kwon, S.T., Tilton, G.R., and Sagge, P..P. 1987. Age and radiogenic isotopic systematics of the Borden carbonatite complex, Ontario, Canada. Canadian Journal of Earth Sciences, 24, pp. 24-30.

Berthe, D., Choukroune, P. and Jegouzo, P., 1979. Orthogneiss, mylonite and non-coaxial deformation of granites: the example of the South Armorican shear zone. Journal of Structural Geology, 1, pp. 31-42.

Best, M.G. 1975. Migration of hydrous fluids in the upper mantle and potassium variation in calc-alkaline rocks. Geology 3, 429-32.

Beyth, M. 1971. Geology of Central and Western Tigre. Unpublished Report. Ethiopian Institute of Geological Surveys.

Black, R. 1984. The Pan-African event in the geological framework of Africa. Pangea, 2, pp. 6-16.

Brown, G.C. 1982. Cale alkaline intrusive rocks - their diversity. evolution and relation to volcanic arcs. In: Thorpe, R.S. (ed.) Andesites. John Wiley, New York. pp. 437-461.

Bruhun, R.L., Stern, C.R. and de Wit, M.J., 1978. The bearing of new field and geochemical data on the origin and development of a Mesozoic tectonic rift zone and back-arc basin in southernmost South America. Earth and Planetary Scicnce Letters, 41, pp. 32-46.

Bokhari, F.Y., and Kramers, J.D. 1981. Island arc character and late Precambrian age of volcanics at Wadi Shwas, Saudi Arabia: geochemical, Sr and Nd isotopic evidence. Earth and Planetary Science Letters, 54, pp. 409-522.

Burke, K.C., and Dewey, J.F., 1973. An outline of Precambrian plate development. In: D.H. Tarling and S.K. Runcorn (eds.). Implications of continental drift to the Earth Sciences. Academic Press, London, 2, pp. 1035-1045.

Burnham, C.W. 1979. Magmas and hydrothermal fluids. In: H.L. Barnes (ed.), Geochemistry of hydrothermal ore deposits. $2^{\text {nd }}$ ed. Wiley, New York, pp. 71-136. 
Cahen, L. 1961. Review of geochronological knowledge in middle and northern Africa. In: Geochronology of rock systems. Annals. New York Academy of Science, 91, 535-566.

Cahen, L. and Snelling. N.J. 1966. Geochronology of Equatorial Africa. North-Holland Publishing Company, Amsterdam. 195 p.

Cahen, L., Snelling, N.J., Delhal, J., and Vail, J.R. 1984. The Geochronology and Evolution of Africa. Clarendon Press, Oxford. 512p.

Camp, V.E., Jackson, N.J., Ramsay, C.R., Roobol, M.J., Stoesser, D.B., and White, D.L. 1984. Discussion of The Upper Proterozoic ophiolite melange zones of the easternmost Arabian Shield. Journal of Geological Society of London, 141, pp. 1083-87.

Carmichael, D. M. 1985. Lecture notes on P-T petrogenetic grid for part of the model metapelitic system $\mathrm{SiO}_{2}-\mathrm{Al}_{2} \mathrm{O}_{3}-\mathrm{FeO}-\mathrm{MgO}$ $-\mathrm{Na}_{2} \mathrm{O}-\mathrm{K}_{2} \mathrm{O}$ (unpublished).

Chater, A.M. and Gilboy, C.F., 1970. Stratigraphic and structural relations in the Shakisso-Arero region of southern Ethiopia. Annual Report, Research Institute of African Geology. Leeds University, 14, pp. 8-11.

Chater, A.M. 1971. The Geology of the Megado area of Southern Ethiopia. Unpublished Ph.D. thesis, Leeds University. England.

Chappell, B.W. and White, A.J.R. 1974. Two contrasting granite types. Pacific Geology, 8, pp. 173-174.

Clark, A.M.S. 1978. Chemical and mineralogical development of the Sidamo Nickeliferous Serpentinites, Ethiopia. Mineralium Deposita, 13, 221-234.

Clarke, D.B. and Halliday, A.N. 1980. Strontium isotope geology of the South Mountain batholith, Nova Scotia, Geochimica et Cosmochimica Acta, 44, pp. 1045-1058.

Clarke, D.B. 1981. The mineralogy of peraluminous granites: a review. Canadian Mineralogist, 19, pp. 3-17.

Clemens, J.D. and Wall, V.J. 1981. Origin and crystallization of some peraluminous (S-type) granitic magmas. Canadian Mineralogist, 19, pp. 111-131. 
Clifford, T.N. 1970. The structural framework of Africa. In: T.N. Clifford and Gass, I.G. (eds.), African Magmatism and Tectonics. Edinburgh, Oliver and Boyd, pp. 1-26.

Coleman, R.G., and Peterman, Z.E. 1975. Oceanic plagiogranite. Journal of Geophysical Research, 80, pp. 1099-1108.

Coleman, R.G., and Donato, M.M. 1979. Oceanic plagiogranite revisited. In: Barker, F. (ed.). Trondhjemites, Dacites, and Related Rocks. Elsevier, Amsterdam. pp. 149-68.

Collins, W.J., Beams, S.D., White, A.J.R., and Chappell, B.W. 1982. Nature and origin of A-type granites with particular reference to southeastern Australia. Contributions 10 Miners.logy and Petrology, 80, pp. 189-200.

Condie, K.C., and Hunter, D.R. 1976. Trace element geochemistry of Archacan granitic rocks from the Barberton region, South Africa. Earth and Planetary Science Letters, 29, pp. 389-400.

Coolen J.J.M., Priem, H.N.A., Verdurmen, A.E., and Verschure, R.A. 1982. Possible zircon U-Pb evidence for Pan-African granulite facies metamorphism in the Mozambique Belt of southern Tanzania, Precambrian Research, 17, pp. 31.40.

Cullers, R.L., and Graf, J.L. 1986. Rare earth elements in igneous rocks of the continental crust: Intermediate and silicic rocks -ore petrogenesis. In: Henderson, P. (ed.). Rare Earth Element Geochemistry. Elsevier, Amsterdam, pp. 275-316.

Dainelli, G. 1943. Geologia dell Africa Orientale. Realc Academia d'Italia. 3 vols. text and one vol. maps.

Davidson, A. (Compiler) 1983. The Omo River Project Reconnaissance Geology and Geochemistry of parts of Illubabor, Kefa, Gemu Gofa and Sidamo, Ethiopia. Omo River Pruject, Canadian International Development Agency, 89p.

DePaolo, D.J. and Johnson, R.W. 1979. Magma genesis in the New Britain island arc: constraints from $\mathrm{Nd}$ and $\mathrm{Sr}$ isotopes and trace element patterns. Contributions to Mineralogy and Petrology. 70, pp. $367-379$.

Dewey, J.F. and Bird, J.M. 1971. Origin and emplacement of the ophiolite suite: Appalachian ophiolites in Newfoundland. Journal of Geophysical Research, 76, pp. 3179-3206. 
de Wit, M.J., 1977. Notes on the Geology of Part of Sheet NC-3616 (Gore). Ethiopian Institute of Geological Surveys. Note 56.

de Wit, M.J. and Berg, R. 1977. Nickel, Platinium and Chromium Mineralization at Tullu Dimtu, Wollega. Ethiopian Institute of Geological Surveys. Note 58.

de Wit, M.J. and Aguma, A. 1977. Geology of the Ultramafic and Associated Rocks of Tullu Dimtu, Wollega. Ethiopian Institute of Geological Surveys. Note 57.

de Wit, M.J., and Chewaka, S. 1981. Plate tectonic evolution of Ethiopia and the origin of its mineral deposits: An overview. In: Chewaka, S. and de Wit, M.J. (eds.), Plate Tectonics and Metallogenesis: Some Guidelines to Ethiopian Mineral Deposits. Ethiopian Institute of Geological Surveys, Bulletin 2, pp. 115-119.

Dixon, T.H. 1981. Age and chemical characteristics of some pre- Pan African rocks in the Arabian Shield. Precambrian Rescarch. 14, pp. 119-133.

Duyverman, H.J., Harris. N.B.W., and Hawkesworth, C.J. 1982. Crustal accretion in the Pan African: Nd and Sr isotope evidence from the Arabian Shield. Earth and Planetary Science Letters, 59. pp. 315-326.

Engel, A.E.J., Dixon, T.H., and Stern, R.J. 1980. Late Precambrian evolution of Afro - Arabian crust from ocean arc to crator. Geological Society of America Bulletin, 91, pp. 699-706.

England, P.C. and Thompson, A. 1986. Some thermal and tectonic models for crustal melting in continental collision zones. In: M.P. Coward and A. C. Ries (eds.), Collision Tectonics. Geological Society Special Publication. Blackwell Scientific Publications, London, 19, pp. 83-94.

Evensen, N.M., Hamilton, P.J. and O'Nions, R.K., 1978. Rare-earth abundances in chondritic meteorites. Geochimica et Cosmochimica Acta, 12, pp. 1199-1212.

Faure. G. 1986. The Principles of Isotope Geology, $2^{\text {nd }}$ ed., Wiley, New York, 589p.

Ficld, D., and Raheim, A. 1979. A geologically meaningless Rb-Sr total rock isochron. Nature, 282, pp. 497-499. 
Fitches, W.R., Graham, R.H., Hussein, I.M., Ries, A.C., Shackleton, R.M., and Price, R.C. 1983. The late Proterozoic ophiolite of Sol Hamed, N.E. Sudan. Precambrian Research, 19, pp. 385-411.

Fleck, R.J., Greenwood, W.R., Hadley, D.G., Anderson, R.E., and Schmidt, D.L. 1980. Age and evolution of the southern part of the Arabian Shield. In: Evolution and Mineralization of the Arabian-Nubian Shield, Institute of Applied Geology. Jeddah. Pergamon press, Oxford, 4, pp. 1-17.

Floyd, P.A. and Winchester, J.A. 1983. Element mobility associated with meta-shear zones within the Ben Hope amphibolite suite. Scotland. Chemical Geology, 39, pp. I-15.

Fourcade, S., and Allegre, C.J. 1981. Trace clement behaviour in granite genesis: a case study. The calc-alkaline plutonic association from the Querigut complex (Pyrenees. France). Contributions to Mineralogy and Petrology, 76. pp. 177.95.

Frazier, S.B. 1970. Adjacent structures of Ethiopia: that portion of the Red Sea coast including Dahlak - Kebir Island and the Gulf of Zula. Royal Socicty of London, Philosophical Transactions, A267, 131-141.

Froese, E. 1973. The assemblage quartz-K feldspar-biotite-garnetsillimanite as an indicator of $\mathrm{PH}_{2} \mathrm{O}$ - $\mathrm{T}$ conditions. Canadian Journal of Earth Sciences, 10, pp. 1575-1579.

Fullagar, P.D., and Greenberg. J.K. 1978. Egyptian younger granites: A single period of plutonism? Precambrian Research, 6, p. 22.

Fyfe, W.S. 1979. Comment on I.G. Gass, Evolutionary model for the Pan-African crystalline basement. In: A. Al Shanti (ed.). Evolution and Mineralization of the Arabian-Nubian Shicld. Institute of Applied Geology Bulletin. Pergamon Press. Jeddah. 1, pp. 11-2\%.

Gabert, G. 1984. Structural-lithologic units of Proterozoic rocks in East Africa, their base, cover and mineralization. In: African Geology, J. Klerkx and J. Michot (eds.). Musee Royal de l'Afrique Centrale - Tervuren. pp. 11-22.

Gamechu, D. 1977. Aspects of elimate and water budget in Ethiopia. Addis Abeba University Press.

Gass, I.G. 1977. The evolution of the Pan-African crystalline basement in NE Africa and Arabia. Journal of Geological Socicty of London, 134, pp. 129-38. 
Gass, 1.G. 1979. Evolutionary model for the Pan-African crystalline basement. In: Evolution and Mineralization of the Arabian Nubian Shield. Institute of Applied Geology Bulletin, Jeddah. Pergamon Press. 1, pD. II-29.

Gass, I.G. 1981. Pan-African (Upper Proterozoic) plate tectonics of the Arabian-Nubian Shield. In: Precambrian Plate Tectonics. A. Kroner (ed.). pp. 388-405.

Gerasimovskii, V.T. 1956. Geochemistry and mineralogy of nepheline syenite intrusions. Geochemistry, 5, 494-510.

Gherardi, D. 1951. Preliminary geological survey of Eritrea. Mining Magazine, 84, pp. 265-276.

Gilboy. C. 1970. The Geology of the Gariboro Region of Southern Ethiopia. Unpublished Ph.D. thesis, Leeds University, Egland.

Gilboy, C., and Chater, A.M. 1970. Stratigraphic and structural relations in the Shakisso-Arero region of southern Ethiopia. $4^{\text {th }}$ Anaual Report, of Research Institute of African Geology. Leeds University.

Gill. J.B. 1981. Orogenic Andesites and Plate Tectonics. SpringerVerla8, New York. 390p.

Gill, J.B., and Stork, A.L. 1979. Miocene low-K dacites and trondhjemites of Fiji. In: Barker, F. (ed.), Trondhjemites. Dacites and Related Rocks. Elsevier, Amsterdam. pp. 629-49.

Glikson, A.Y. and Sheraton, J.W. 1972. Early Precambrian evidence of a primitive ocean crust and island nuclei of sodic granite. Geological Society of America Bulletin, 83, 3323-3344.

Goldich, S.S. and Mudrey, M.J., Jr. 1972. Dilatancy model for U-Pb zircon ages. In: Contribution to recent geochemistry and analytical chemistry. Vinogradov volume, A.L. Tagarinov (ed.), Moscow. pp. 415-418.

Greene. T.H., and Ringwood, A.E. 1968. Genesis of the calc alkaline igneous rock suite. Contributions to Mineralogy and Petrology. 18, pp. 105-62.

Greenwood, W.R., Hadley, D.G., Anderson, R.E., Fleck, J.R., and Schmidt, D.L. 1976. Late Proterozoic cratonization in southwestern Saudi Arabia. Royal Society of London Philosophical Transactions, A280, pp. 517-527. 
Gromet, L.P. and Silver, L.T. 1983. Rare earth element distributions among minerals in granodiorite and their petrogenetic implications. Gcochimica et Cosmochimica Acta, 47, pp. 925. 939.

Hanson, G.N. 1980. Rare earth elements in petrogenetic studies of igneous systems. Annual Review of Earth and Planetary Sciences, 8, 371-406.

Harris, N.B.W. 1982. The petrogenesis of alkaline intrusives from Arabia and Northwest Africa and their implications for withinplate magmatism. Tectonophysics, 83, pp. 243-258.

Harris, N.B.W., Hawkesworth, C.J., and Ries, A.C. 1984. Crustal evolution in north-east and east Africa from model Nd ages. Nature, 309, pp. 773-776.

Harris, N.B.W., Pearce, J.A., and Tindle, A.G. 1986. Geochemical characteristics of collision-zone magmatism. In: Coward, M.P. and Ries. A.C. (eds.), Collision Tectonics. Geological Society Special Publication, 19, pp. 67-81.

Hepworth, J.V. 1972. The Mozambique orogenic belt and its foreland in north-east Tanzania - a photogeologically-based study. Quarterly Journal of the Geological Socicty of London, 128. 461-500.

Hepworth, J.V. 1979. Does the Mozambique orogenic belt continue into Saudi Arabia? In: Evolution and Mincralization of the Arabian-Nubian Shield. Institute of Applied Geology, Jeddah, 3, pp. 39-51.

Hepworth, J.V. 1980. Letter to the editor, In: Cooray, G. (ed.). Newsletter, IGCP Project 164, 3, pp. 41-42.

Hietanen, A., 1963. Idaho batholith near Pierce and Bungalow. Clearwater county, Idaho: United States Geological Survey. Professional Pafer, 344-A, 116p.

Hine, R., Williams, I.S., Chappell, B.W and White, A.J.R. 1978. Contrasts between I- and S-type granitoids of the Kosciusko batholith. Geological Society of Australia Journal, 25, 219234.

Hoffmann, A. and Gilletti, B.J. 1970. Diffusion of geochronologically important nuclides under hydrothermal conditions. Eclogac Geologii Helvetiae, 63, 141-150. 
Holmes, A.B., 1951. The sequence of Precambrian orogenic belts in south and central Africa. 18th International Geological Congress, 14, pp. 254-269.

Husscin, I.M, Kroner, A., and Durr S. 1982. Wadi Onib: a dismembered Pan-African ophiolite in the Red Sea Hills of Sudan. Precambrian Research, 16, pp. 52-74.

Ishihara, S. 1977. The magnetite-series and ilmenite-series granitic rocks. Mining Geology, 27, pp. 293-305.

Jackson, N.J. 1986. Petrogenesis and evolution of Arabian plutonic rocks. Journal of African Earth Sciences, 4, pp. 47-59.

Jackson, N.J., and Ramsay, C.R. 1979. What is the Pan-Arrican? A consensus is needed. Geology, pp. 210-211.

Jackson, N.J., and Ramsay, C.R. 1980. Time - space relationships of Upper Precambrian volcanics and sedimeniary units in the central Arabian Shield. Journal of the Geological Society of London, 137, pp. 617-628.

Jelenc, D. 1966. Mineral occurrences of Ethiopia. Ministry of Mines. Addis Abeba, Ethiopia.

Kazmin, V. 1971. Precambrian of Ethiopia. Nature, Physical Science, 230(16), pp. 176-177.

Kazmin, V. 1972a. Geological map of Ethiopia. Lat. $4^{\circ} 00^{\circ}$ to $18^{\circ} 00^{\prime}$. Long. $34^{\circ} 00^{\circ}$ to $48^{\circ} 00^{\circ}$, Scale 1:2,000,000. Ethiopian Institute of Geological Surveys.

Kazmin, V. 1972b. Some aspects of Precambrian development in east Africa. Nature, 237, pp. 160.

Kazmin, V. 1972c. Geology of Ethiopia. Ethiopian Institute of Geological Surveys. Unpublished.

Kazmin, V. 1975a. Explanation of the geological map of Ethiopia. Ethiopian Institute of Geological Surveys. Bulletin, 1.

Kazmin, V. 1975b. The Precambrian of Ethiopia and some aspects of the geology of the Mozambique Belt. Geophysical Observatory Bulletin, Addis Ababa, 15, pp. 27-43.

Kazmin, V. 1976. Ophiolites in the Ethiopian basement. Ethiopian Institute of Geological Surveys. Note 35, 16p. 
Kazmin, V. 1978a. Geology of the Tullu Dimtu area. Ethiopian Institute of Geological Surveys. Note 90.

Kazmin, V. 1978b. Geology of the Ethiopian basement and the possible relationship between the Mozambique and the Red Sea fold belts. Egypt Journal of Geology, 22(1), pp. 73-86.

Kazmin, V. 1979. Relationship between Rifts and Precambrian basement in East Africa. Annals of Geological Survey of Egypt, 9, pp. 54-60.

Kazmin, V., Shiferaw, A., and Balcha, T. 1978. The Ethiopian basement: stratigraphy and possible manner of evolution. Geologische Rundschau, 67(2), pp. 531-546.

Kazmin, V., Tefera, M. Berhe, S.M. and Chewaka, S. 1979. Precambrian structure and metallogeny of western Ethiopia. Annals. Geological Survey of Egypt, 9, pp. 1-18.

Kennedy, W.Q. 1964. The structural differentiation of Africa in the Pan-African (+/-500 m.y.) tectonic episode. Annual Report. Institute of African Geology, Leeds University, 8, pp. 48-49.

Kennan, P.S. and Murphy, F.C. 1987. Tectonically reset Rb-Sr system during Late Ordovician terrane assembly in Iapetus, western Ireland. Geology, 15, 1155-1158.

Kistler, R.W., 1974. Phanerozoic batholiths in western North America: a summary of some recent work on variations in time, space, chemistry and isotopic compositions. Annual Reviews of Earth and Planetary Sciences, 2, pp. 403-418.

Klerkx, J. and Deutsch, S. 1977. Resutats preliminaires obtenus par la methode Rb/Sr sur l'age des formations precambricnnes de is region d' Uweinat (Libya). Rapport Annuel, Musec Royal de l'Afrique Centrale, Tervuren.

Kozyrev, V. and others, 1985. Adola Gold Exploration Project, Part 2, Regional geological mapping and prospecting. Unpublished report. Ethiopian Institute of Geological Surveys.

Kretz, R. 1985. Calculation and illustration of uncertainty in Geochemical Analyses. Journal of Geological Fducation, 33. pp. $41-45$.

Krogh, T.E. 1982. Improved accuracy of U-Pb ages by the creation of more concordant systems using an air abrasion techniquc. Geochimica et Cosmochimica Acta, 46, pp. 637-649. 
Krogh, T.E. and Davis, G.L. 1973. The significance of inherited zircons on the age and origin of igneous rocks - an investigation of the Labrador adamellites: Carnegie Institution Washington Yearbook, 72, 610-613.

Kroner, A. 1977. Precambrian mobile belts of southern and eastern Africa - ancient sutures or sites of ensialic mobility? A case for crustal evolution towards plate tectonics. Tectonophysics, 40, pp. 101-135.

Kroner, A. 1979. Pan-African mobile belts as evidence for a transitional tectonic regime from intraplate orogeny to plate margin orogeny. In: Evoluition and mineralization of the Arabian - Nubian Shield. Institute of Applied Gealogy, Jeddah, 1, pp. 21-38.

Kroner, A. 1985. Ophiolites and the evolution of tectonic boundaries in the late Proterozoic Arabian-Nubian Shicld of northeastern Africa and Arabia. Precambrian Research, 27, pp. 277-300.

Kroner, A., Roobol, M.J., Ramsay, C.R., and Jackson, N.J. 1979. Pän African ages of some gneissic rocks in the Saudi Arabian Shield. Journal of the Geological Socicty of London, 136, pp. 455-461.

Leggo, P.J. 1971. Discordant U-Pb ages from Uganda basement. Nature 231, pp. $81-86$.

Leggo. P.J. 1974. A geochronological study of the basement complex of Uganda. Journal of the Geological Society of London, 130, pp. 263-278.

Le Maitre, R.W. 1976. The chemical variability of some common igneous rocks. Journal of Petrology, 17, pp. 589-637.

Levitte, D. and Kent, G. 1968. Nickeliferous Laterites of Sidamo. (unpublished report).

Libling, G., and Nowack, E. 1939. Geologische Forschungen im Tschertscher Gebirge, Ost Abessiniens. Neues Jahrbuch fur Mineralogie, 10, Beilage Band 81 .

Loiselle, M.C. and Wones, D.R. 1979. Characteristics of anorogenic granites. Abstracts, Geological Society of America, Annual Meeting, 1979, p. 539.

Ludington, S. 1978. The biotite-apatite geothermometer revisited. American Mineralogist, 63, pp. $551-553$. 
Ludwig, K. 1980. Calculation of uncertainties of U-Pb isotope data: Earth and Planetary Science Letters, 46, 212-220.

Maaloe, S. and Wyllie, P.J. 1975. Water content of granite magma deduced from the sequence of crystallization determined experimentally with water-undersaturated conditions. Contributions to Mineralogy and Petrology, 52, pp. 175-191.

Martin, H. and Porada, H. 1977. The intracratonic branch of the Damara Orogen in southwest Africa. 1. Discussion of geodynamic models. Precambrian Research, 5, pp. 311.

Meinhold, K.D. 1979. The Precambrian basement complex of the Bayuda Desert, northern Sudan. Revue de Geologie Dynamique, 21, DP. 395-401.

Merla, G., Abbate. E., Canuti, P., Sagu, M. and Tacconi, P. 1973. Geological map of Ethiopia and Somalia. Explanatory notes (1979). Consiglio Nazionale delle Ricerche, Firenze, Italy.

Metal Mining Agency of Japan. 1974. Report on the Geological Survey of Wollega Area, western Ethiopia. Unpublished report.

Miller, J.A., Mohr, P.A., and Rogers, A.S. 1967. Some new K/Ar age determinations of basement rocks from Eritrea. Geophysical Observatory Bulletin, Addis Abeba, 10, pp. 53-57.

Mitchelle, A.H.G., and Reading, H.G. 1978. Sedimentation and tectonics. In: H.G. Reading (ed.), Elsevier, pp. 439-476.

Miyashiro, A. 1973. Metamorphism and Metamorphic Belts. New York, Halsted Press. 492p.

Mohr, P.A., 1962 (reprinted in 1971). The geology of Ethiopia. Haile Sellassie 1 University, Ethiopia, 264p.

Molly, E.W. 1959. Platinium deposits of Ethiopia. Economic Geology, 54, no. 3.

Moore, J.M. Morgan, J., Teferra, $M$ and Teklay, $M$ 1987. Geology of the Gore-Gambella geotraverse, western Ethiopia. In: G. Matheis and H. Schandelmeier (eds.), Current Research in African Earth Sciences. Balkema, Rotterdam/Boston. pp. 109. 112.

Moorhouse, W.W. 1968.The study of rocks in thin section. Harper Geoscience series, New York. p. 514. 
Morton, W.H. 1975. The Geology of Enticho, Tigre. Geophysical Observatory Bulletin, Addis Ababa. 15, pp. 1-14.

Mottana, A., Church, W.R. and Edgar, A.D., 1968. Chemistry, mineralogy and petrology of an eclogite from the type locality (Sualpe, Austria). Contributions to Mineralogy and Petrology, 18, pp. 338-346.

Mysen, B.O. 1979. Trace element partitioning between garnet peridotite minerals and water-rich vapour: experimental data from 5 to 30Kb. American Mineralogist, 64, pp. 274-87.

Naney, M.T. 1983. Phase equilibria of rock forming ferromagnesian silicates in granitic systems. American Journal of Science, 283, pp. 993-1033.

Norrish, K. and Hutton, J.l. 1969. An accurate X-ray spectrographic method for the analysis of a wide range of geological samples. Geochimica et Cosmocinimica Acta, 33, pp. 431-453.

O'Connor, J.T. 1965. A classification for quartz-rich igneous rocks based on feldspar ratios. U.S.Geological Survey Professional Paper, 525-B, pp. 79-84.

Omo River Project Team 1973. Preliminary Report on the Geology and Geochemistry of Parts of Sidamo, Gemu Gofa, and Kefa Provinces. Ministry of Mines, Omo River Project, Report, 1, Addis Abeba, 2 I p.

Omo River Project Team 1976. Preliminary Report on the Geology and Geochemistry of Parts of Gemu Gofa, Kefa, and Illubabor Provinces. Ministry of Mines, Omo River Project, Report, 2. Addis Abeba, 28p.

Parrish, R., and Roddick, J.C. 1985. Geochronology and isotope geology for the geologist and explorationist. Geological Society of America, Cordilleran Section. Short course No. 4, Notes.

Parrish, R.R., Roddick, J.C., Loveridge, W.D., and Sullivan, R.W. 1987. Uranium - lead analytical techniques at the geochronology laboratory. Geological Survey of Canada, Paper, 87-2, pp. 3-6.

Pearce, J.A., Lippard, S.J. and Roberts, S. 1984. Characteristics and tectonic significance of supra-subduction zone (ssz) ophiolites. In: B.P. Kokelaar, and M.F. Howells (eds.), Ophiolites and Oceanic Lithosphere.Geological Society Special Publication, 16, pp. 77-94. 
Pearce, J.A., Herris, N.B.W., and Tindle, A.G. 1984. Trace element discrimination diagrams for the tectonic interpretation of granitic rocks. Journal of Petrology, 25, pp. 956-983.

Peccerillo, A., and Taylor, S.R. 1976. Geochemistry of Eocene calc alkaline volcanic rocks from the Kastamonu area, northern Turkey. Contributions to Mineralogy and Petrology, 58, pp. 63-81.

Peterman, Z.E. 1979. Strontium isotope geochemistry of late Archean 10 late Cretaceous tonalites and trondhjemites. In: Barker, F. (ed). Trondhjemites, dacites and related rocks. Elsevicr. pp. 133-147.

Petro, W.L., Vogel, T.A. and Wilband, J.T. 1979. Major-element chemistry of plutonic rock suites from compressional plate boundaries. Chemical Geology, 26, 217-235.

Pitcher, W.S. 1978. The anatomy of a batholith. Journal of the Geological Society of London, 135, pp. 157-182.

Pitcher, W.S. 1983. Granite type and tectonic environment. In: Mountain Building Processes, K. Hsu (ed.). Academic Press. pp. 19-40.

Pohl, W. 1981. Is the Kashebib Group older basement to the Greenschist assemblage? In: A.M. Al-Shanti (ed), Newsletter, IGCP Project 164. Institute of Applied Geology, Jeddah. 4, pp. 4448.

Presnall, D.C., Bateman, P.C. 1973. Fusion relations in the system $\mathrm{NaAlSi}_{3} \mathrm{O}_{8}-\mathrm{CaAlSi}{ }_{2} \mathrm{O}_{8}-\mathrm{KAISi}_{3} \mathrm{O}_{8}-\mathrm{H}_{2} \mathrm{O}$ and generation of granitic magmas in the Sierra Nevada batholith. Geological Society of America Bulletin, 84, 3181-3202.

Ramberg,H. 1952. The origin of metamorphic and metasomatic rocks. University of Chicago. Chicago.

Ramsay, C.R. 1979. In defense of the Pan-African - In: Cooray, G. (ed.) Newsletter, IGCP - Project 164. Institute of Applied Geology, Jeddah. 2, pp. 22-23.

Ries, A.C., Shackleton, R.M., Gratiam, R.H., and Fitches, W.F. 1983. Pan-African structures, ophiolites and melanges in the Eastern Desert of Egypt. Journal of the Geologicai Society of London. 
Ries, A.C., Shackleton, R.M. and Dawoud, A.S. 1985. Geochronology, geochemistry and tectonics of the NE Bayuda Desert, N. Sudan: implications for the Western Margin of the Late Proterozoic fold belt of NE Africa. Precambrian Research, 30, pp. 43-62.

Ries, A.C., Vearncombe, J.R., Price, R.C., and Shackleton, R.M. 1986. Geochronology, geochemistry and structure of the rocks associated with a late Proterozoic ophiolite in West Pokot, NW Kenya. (unpublished manuscript).

Ringwood, A.E. 1974. The petrological evolution of island arc systems: Journal of the Geological Society of London, 130, pp. 183-204.

Rogers, A.S., Miller, J.A., and Mohr, P.A. 1965. Age determinations on some Ethiopian basement rocks. Nature, 206, pp. 1021-1023.

Roobol M.J., Ramsay, C.R., Jackson, N.J., and Darbyshire, D.P.F. 1983. Late Proterozoic lavas of the central Arabian Shicldevolution of an ancient volcanic arc system. Journal of the Geological Society of London, 140, pp. 185-202.

Sanders, D.D. 1965. Geology of the contact between the Nyanza shield and the Mozambique Belt in western Kenya. Geological Survey of Kenya Bulletin, 7.

Shackleton, R.M. 1976. Pan-African structures. Royal Society of London, Philosophical Transactions, A280, pp. 491.

Shackleton, R.M. 1977. Possible late-Precambrian ophiolites in Africa and Brazil. 20th Annual Report, Research Institute of African Geology, Leeds University, pp. 3-7.

Shackleton, R.M. 1986. Precambrian collision tectonics in Africa. In: M.P. Coward and A. C. Ries (ed.), Collision Tectonics. Geological Society Special Publication, 19. Blackwell Scientific Publications, London, pp. 329-352.

Shackleton, R.M., Ries, A.C., Graham, R.H., and Fitches, W.R., 1980. Late Precambrian ophiolitic melange in the eastern desert of Egypt. Nature, 285, pp. 472-474.

Shand, S.J. 1951. Eruptive Rocks. Wiley, New York, 488p.

Shibata, K. 1975. Preliminary geochronological study on metamorphic rocks from the Taita Hills, southern Kenya. 1st Preliminary Report, African Studies, Nagoya University, pp. 72-75.

Sibson, R.H. 1977. Fault rocks and fault mechanisms. Journal of the Geological Society of London, 133, pp. 191-213. 
Speer, J.A. 1982. Zircon. In: P.H. Ribbe (ed), Orthosilicates Mineralogical Society of America, Reviews in Mineralogy, S, pp. 67-106.

Spooner, C.M., Hepworth, J.V., and Fairbairn, H.W. 1970. Whole-rock Rb-Sr isotopic investigation of some African granulites. Geological Magazine, 107, pp. S11-521.

Stacey, J.S., Stoesser, D.B., Greenwood, W.R., and Fischer, L.B. 1984. U-Pb zircon geochronology and seologic evolution of the Halaban-Al Amar region of the eastern Arabian Shield. Journal of the Geological Society of London, 141, pp. 1043. 1055.

Stacey, J.S., and and Hedges, C.E. 1984. Geochronologic and isotopic evidence for early Proterozoic continental crust in the eastern Arabian Shield. Geology, 12, pp. 310-313.

Stacey, J.B., and Agar, A. 1985. U-Pb isotopic evidence for the accretion of a continental microplate in the Zalm region of the Saudi Arabian Shield. Journal of the Geological Society of London, 142, pp. 1189-1204.

Steiger, R.H., and Jager, E., 1977. Subcommission on Geochronology: convention and use of decay constants in geo- and cosmochronology. Earth and Planetary Science Letters, 35, pp. 359-362.

Stern, R.J. 1979. Late Precambrian ensimatic volcanism in the central Eastern Desert of Egypt. Unpublished Ph.D. thesis, University of California, San Diego.

Stoesser, D.B., and Camp, V.E. 1985. Pan African microplate accretion of the Arabian Shield. Geological Society of America Bulletin.

Stormer, J.C. 1975. A practical two-feldspar geothermometer. American Mineralogist, 60, pp. 667-674.

Stormer, J.C. and Carmichael, I.S.E. 1971. Fluorine - hydroxyl exchange in apatite and biotite: $A$ potential igneous geothermometer, Contributions to Mineralogy and Petrology, 31, 121-131.

Streckeisen, A. 1976. To each plutonic rock its proper name. Earth Science Reviews, 12, pp. 1-33.

Suwa, K. 1979. Precambrian of the African continent. Mem. Nat. Inst. Polar Research, Tokyo, 14, pp. 93-105. 
Taylor, S.R. 1979. Chemical composition and evolution of the continental crust. American Geophysical Union, Maurice Ewing Series, 1, pp. 325-335.

Taylor, S.R. and Mclennan, S.M. 1985. The continental crust: its composition and evolution. Blackwell Scientific Publications, Oxford. 312p.

Teferra, M. and Berhe S.M. 1987. Geology of sheet NC $36-16$ (Gore sheet). Ethiopian Institute of Geological Surveys. Unpublished manuscript.

Tuttle, O.F., and Bowen, N.L. 1958. Origin of granite in the light of experimental studies in the system $\mathrm{NaAlSi}_{3} \mathrm{O}_{8} \cdot \mathrm{KAlSi}_{3} \mathrm{O}_{8}$. $\mathrm{SiO}_{2}-\mathrm{H}_{2} \mathrm{O}$. Geological Society of America, Memoir, 74, pp. $1-152$.

United Nations Development Program 1972. Mineral Survey in Two Selected Areas. United Nations, New York.

Usoni, L. 1952. Risorse minerarie dell'Atrica Orientale, Ethiopia, Somalia, Jandi Sapi, Roma, 553 p.

Vail, J.R. 1976. Outline of the geochronology and tectonic units of the basement complex of northeast Africa. Proceedings of Royal Society of London, A350, pp. 127-141.

Vail, J.R. 1982. Distribution and tectonic setting of post-kinematic igneous complexes in the Red Sea Hills of Sudan and the Arabian and Nubian Shicld. Precambrian Research, 16, pp. 41 42.

Vail, J.R. 1983. Pan-African crustal accretion in north-east Africa. Journal of African Earth Sciences, 1, pp. 285-294.

Vail, J.R. 1984. The nature of the basement complex of the Nubian Shield in northeast Africa: Addendum. Journal of African Earth Sciences, 2(4), pp. 389-390.

Vail, J.R. 1985. Relationship between tectonic terrains and favourable metallogenic domains in the Central Arabian-Nubian Shield. Institute of Mining and Metallurgy Transactions. Section B, Applied Earth Sciences, 94, pp. 1-6.

Vearncombe 1981. Possible ophiolites from the Pan-African of west Pokot, Kenya. I1th colloquium of African Geology, Milton Keynes, Abstracts, pp. 9. 
Warden, A.J. 1982. The northeast branch of the Mozambique Belt. Precambrian Research, 16, pp. 41-42.

Warden, A.J. and Horkel, A.D. 1984. The geological evolution of NEbranch of the Mozambique Belt (Kenya, Somalia, Ethiopia) Mitteilungen Osterreich Geol. Ges., 77, pp. 161-184.

Wetherill, G. 1956. Discordant uranium-lead ages. Transactions, American Geophysical Union, 37, pp. 320-326.

Wendt, I., Besang, C., Harre, W., Kreuzer, H., Lenz, H. and Muller. P. 1972. Age determinations of granitic intrusions and metamorphic events in the Early Precambrian of Tanzania. 24th International Geological Congress, Montreal, Section 1, pp. 295-314.

White, A.J.R., and Chappell, B.W. 1977. Ultrametamorphism and granitoid genesis. Tectonophysics, 43, pp. 7-22.

White, A.J.R., and Chappell, B.W. 1983. Granitoid types and their distribution in the Lachlan Fold Belt, southeastern Australia. Geological Society of America, Memoir 159, pp. 21 34.

Whitney, J.A. and Stormer, J.C. 1977. Two-feldspar geothermometry. geobarometry in mesozonal granitic intrusions: Three examples from the Piedmont of Georgia. Contributios to Mineralogy and Petrology, 63, pp. 51-64.

Whitten, E.T.H. 1966. Struetural geology of folded rocks: RandMeNally, SkoKie, Illinois.

Winchester, J.A. and Floyd, P.A. 1976. Geochemical magma type discrimination: application to a'tered and metamorphosed basic igneous rocks. Earth planetary Science Letters, 28, pp. 459-469.

Winchester, J.A. and Max, M.D. 1984. Element mobility associated with syn-metamorphic shear zones near Scotchport, NW Mayo, Ireland. Journal of Metamorphic Geology, 2, pp. 1-11.

Winkler, H.G.F. 1979. Petrogenesis of metamorphic rocks. Spriuger. verlag, Berlia. 254p.

Wood, D.A. 1979. A variably veined sub-oceanic upper mantle - genetic significance for mid-oceanic ridge basalts from geochemical evidence. Geology, 7, pp. 499-503. 
Wright, J.B. 1969. A simple alkalinity ratio and its application to questions of non-orogenic granite genesis. Geological magazine, 106, pp. 370-384.

Wyllie, P.J., Huang, W., Stern, C.R. and Maaloe, S. 1976. Granitic magmas: Possible and impossible sources, water contents, and crystallization sequences. Canadian Journal of Earth Sciences, 13, 1007-1019.

Wyllie, P.J. 1977. Crustal anatexis: an experimental review. Tectonophysics, 43, pp. 41-71.

York. D. 1969. Least squares fitting of a straight line with correlated errors. Earth and Planctary Science Letters, 2, pp. 320-324.

Zen, E-an. 1985. Implications of magmatic epidote-bearing plutons on crustal evolution in the accreted terranes of northwestern North America. Geology, 13, pp. 266-269.

Zen, E-an and Hammarstrom, J. 1984. Magmatic epidote and its petrologic significance. Geology. 12, pp. 515-518.

Zen, E-an and Hammarstrom, J. 1986. "Implications of magmatic epidotebearing plutons on crustal evolution in the accreted terranes of northwestern North America" and "Magmatic epidote and its petrologic significance" - REPLY. Geology, 14, pp. 188-189. 


\section{APPENDIX 1}

\section{PETROGRAPHY}

Typical modes of intrusive units were determined in part using a point counting procedure and these are listed in Table 2.1. Those obtained from metsmorphosed sedimentery and volcanic rocks and gneisses are given in Table 2.2. Brief mineralogical and textural descriptions are provided here for representative samples from the Birbir, Goma, Haya, Bure, Baro. Bonga and Mao plutonic units. Sample localities are given in Figure 2.3.

Birblr: Sample * T3G. Quartz diorite

Mesoscopic features:

- fine-grained, strongly foliated: foliation defined by compositional layering of biotite and hornblende between layers approximately $0.5 \mathrm{~cm}$ thick.

Microscopic features:

Quartz: commonly as anhedral microcrystalline aggregatcs (recrystallized with mosaic microstructure), some flattened; few ribbons up to $2 \mathrm{~mm}$ by $0.2 \mathrm{~mm}$ and as matrix less than $0.5 \mathrm{~mm}$ across, straight grain boundaries, uniform to undulose extinctior. Minor K-feldspar occurs as anhedral interlocking grains with quartz.

- Plagioclase: subhedral-euhedral laths up to $5 \mathrm{~mm}$ by $1.5 \mathrm{~mm}$ occur as porphyroclasts, and $0.5 \mathrm{~mm}$ in the matrix; some show concentric zoning, deformation twins, mantled by very fine-grained recrystallized plagioclase; slightly altered alcng cleavage traces and edges to epidote and calcite.

- Biotite: subhedral-euhedral plates, dark brown to light greenishbrown pleochroism, wrapped around hornblende porphyroclasts, define mylonitic foliation by their orientation.

- Hornblende: cuhedral-subhedral crystals, strong pleochruism from light green to dark green, show preferred orientation 
- Accessory miacrals: euhedral titanite, euhedral zircon commonly included in biotite: abundent apatite generally included in quartz and reldspar.

- Matrix minerals approx. 60-70\%, composed of fine-grained continuous layers quartz- plagioclase and biotitehornblende-epidote

Goma: Sample * T6J. Granodiorite

Mesoscopic features:

- uniform, medium-grained, subhedral-granular, weakly developed planar rabric

Microscopic features:

- Quartz: commonly as fine-grained anhedral matrix and less commonly as stubby phenocrysts, 1 to $3 \mathrm{~mm}$ across, with strain features, including undulose extinction and microfractures penetrated by stringers or irregular patches of secondary minerals, mainly epidote.

- K-feldspar: mainly microcline with subordinate orthoclase, microcline occurs as subhedral perthite phenocrysts, 3 to $5 \mathrm{~mm}$ in diameter, often clouded by sericite alteration.

- Plagioclase: subhedral laths, 2 to $5 \mathrm{~mm}$ in diameter, straight to somewhat embayed grain boundaries, oligoclase (An 12-20), some filled with granular aggregates of epidote and minor calcite, particularly along cleavage traces.

- Biotite: anhedral to subhedral grains, ragged to curved edges, pleochroic: greenish brown to brownish green, strongly altered and intergrown with sagenitic rutile and chlorite.

- Accessory minerals include allanite, titanite, zircon and apatite.

Haya: Sample * T4A. Tonalite

Mesoscopic features:

- Fine-grained, pale grey, strong foliation defined by about $5 \mathrm{~mm}$ to 1 $\mathrm{cm}$ scale compositional layering of biotite and muscovite 
Microscopic features:

- Plagioclase: anhedral, slightly rounded to elongate laths, up to $4 \mathrm{~mm}$ in length, curved to slightly embayed grain boundaries, often sericitized, and containing abundant epidote and calcite.

- Quartz: anhedral, equant to elongate habit, some form long rods. often embayed boundaries. some with undulose extinction. associated with rather rare $K$-feldspars.

- Biotite and muscovite flakes, subhedral laths with straight grain boundaries, straight extinction; planar orientation defines the foliation plagioclase and quartz crystals.

- Accessory minerals are very rare: apatite, titanite.

Bure: Sample * TSD. Hornblende gabbro

Mesoscopic features:

- Fine-grained, strongly deformed, lenticular hornblende-rich layers alternate with plagioclase-rich layers.

Microscopic features:

- Hornblende : abundant, often rimmed by fibrous actinolitic amphibole.

- Plagioclase: lath-shaped, filled with very fine-grained epidote and calcite especially along the edges.

- Accessory minerals include titanite. apatite and abundant opaques.

Baro: Sample * T8F. Biotite granite

Mesoscopic features:

- medium-grained, weakly deformed; leucocratic: colour index $<10$.

Microscopic features:

- Alkali-feldspar: mainly microcline and some perthitic microcline. pervasive sericitization

- Plagioclase: subhedral, predominantly albite, some are myrmekitic 
- Quartz: mainly recrystallized matrix; forms interlocking grains with feldspars, some with undulose extinction; and some occur as fracture fillings.

- Biotite: pale yellow to rusty brown pleochroism, some show chloritization with extensive hematite staining, numerous pleochroic haloes - radiation damage.

- Accessory minerals: zircon, apatite, titanite, and opaque oxides.

Bonga pluton - core: Sample * T8L. Quartz monzonite

Mesoscopic features:

- massive grey to pinkish grey, colour index of about 35; coarse K-feldspar and minor quartz megacrysts; some feldspars are as large as $5 \mathrm{~cm}$ with plagioclase rims about $1 \mathrm{~mm}$ thick (rapakivi texture), fine-grained melanocratic matrix; shows a significant variation in quartz content and the relative proportion of feldspars as well as textural differences (hybrid feature).

\section{Microscopic features:}

Microcline: large subhedral phenoctysts (1 to $4 \mathrm{~cm}$ ) often mantled by plagioclase, slightly altered to sericite; also less commonly enclose plagioclase

- Plagioclase: subhedral-euhedral laths, both as large phenocrysts and matrix, some zoned (An 40-28).

- Quartz with anhedral, sub-rounded or globular habit.

Biotite: subhedral - euhedral plates and laths; poikilitically enclose allanite and zircon. Allanite occurs as non-metamict, euhedral reddish brown zoned crystals.

Subhedral, prismatic hornblende pleochroic: dark green to light green is generally associated with biotite

Plagioclase, quartz, biotite, hornblende together with ubiquitous accessory minerals (allanite, apatite, zircon and titanite) constitute the matrix grains, about 0.5 to $1 \mathrm{~mm}$ in size. 
Bonga pluton - rim: sample * T8K. Alkali-feldspar granite

\begin{abstract}
Alkali-feldspar granite that cuts the megacrystic feldspar quartzmonzonite consists of compositionally homogeneous rock compared to T8L. A slight mineralogical variation with a general decrease in the biotite and hornblende content. The major part of the light minerals are represented by interlocking grains of microcline, quartz and plagioclase. Compared to sample * T $8 \mathrm{~L}$, contains less mafic minerals and more abundant accessory minerals, biotite in large poikilitic form or in small crystals included in other minerals, hornblende as dark green to bluish. green pleochroic, as isolated subhedral crystal.
\end{abstract}

Mao: Sample * T90

Sample, from the eastern margin of the pluton, shows shear band foliation; colour index of about 20; composed of quartz, microcline, plagioclase (sodic oligoclase), biotite and hornblende, and ubiquitous zircon, allanite, apatite and titanite. Most samples contain stilpnomelane and chloritized biotite, and slightly sericitized feldspar. 


\section{APPENDIX 2}

\section{MAJOR- AND TRACE ELEMENT ROCK ANALYSES,}

\section{ANALYTICAL PROCEDURES AND ACCURACY}

Major elements, Ba, Cr, Nb, Ni, Rb, Sr, V, Y, Zn and $\mathrm{Zr}$ were determined by XRF spectrometry using a Philips PW 1410/20 AHP instrument at University of Ottawa. Fused-glass pellets were prepared according to the methods of Norrish and Hutton (1969). One gram of powdered sample was mixed with $5 \mathrm{gm}$ of $\mathrm{Li}_{2} \mathrm{~B}_{7} \mathrm{O}_{4}$ and $0.3 \mathrm{gm} \mathrm{LiF}$ and rused to a glass pellet within a platinum holder. Analyses were undertaken using the wavelength-dispersive method.

The precision of XRF data produced in the laboratory, expressed as percent relative standard deviation is approximately as follows (standard deviation/concentration) * $100:-\mathrm{SiO}_{2}(0.9), \mathrm{TiO}_{2}, \mathrm{Al}_{2} \mathrm{O}_{3}$, FeO, $\mathrm{CaO}$ (0.8), $\mathrm{K}_{2} \mathrm{O}$ (1.2), $\mathrm{MgO}$ (2.0), $\mathrm{Na}_{2} \mathrm{O}$ (2.5), MinO (4), trace elements $(-10)$. Hence 95 percent confidence limits $(+/-25)$ to all data may be calculated. Fur example, $63.52 \% \mathrm{SiO}_{2}$ should read 63.52 $+/-1.14$, or $63.5+/-1.2$. Similarly, 243 ppm Ba should read $243+/-$ 48, or $240+/-50$. There are, therefore only two significant figures in the tabulated analyses; the first is fixed and the second is doubtful. The third figure may be retained for calculations, and the fourth, where given, is meaningless.

Geochemical analyses invariably exhibit uncertainty due to systematic error (inaccuracy). random error (imprecision or precision error), and occasionally to other causes such as impurity (Kretz, 1985). The uncertainty due to systematic error or inaccuracy of the 
XRF analyses was estimated by co-analysing two reference standards, DR-N (Diorite) and GS-N (Granite); their preferred composition (R.V.) values on a dry basis were given by Abbey (1983). These values together with means (X) and standard deviations (S.D.) for these reference standards determined in this study, are tabulated below (Table A2.1). The standard deviation is also given as a percentage of the mean, known as the relative standard deviation (coefficient of variation) or relative error (R.E.). Standard error for most major elements is within $+i-1 \%\left(+/-10 \%\right.$ for $\mathrm{P}_{2} \mathrm{O}_{5}, \mathrm{MnO}$ and trace elements). XRF analytical data are given in Table A2.2, together with CIPW norms, calculated by computer at University of Ottawa are expressed in weight percent. $\mathrm{FeO}_{(\mathrm{T})}$ is total iron, and $\mathrm{DI}=$ Differentiation Index. Sample localities are given in Figure 2.2 . 
Table A3.1: Accuracy determlaed for XRF major- and trace element analyses of reference standards (N: aumber of analyses; $\mathrm{Fe}_{2} \mathrm{O}_{3}$ : total Iroe as $\mathrm{Fe}_{2} \mathrm{O}_{3}$.
ANRT - DR-N(Diorite) $N=11$
ANRT 2 - GS-N (Granite)
N=8

R.V. $\quad \mathrm{X}^{\mathrm{N}=11}$ S.D. $\underset{(\%)}{\text { R.E. }}$

R.V. $\quad \mathbf{X}$

$\mathrm{SiO}_{2} \quad 52.98 \quad 52.56$

$\mathrm{Al}_{2} \mathrm{O}_{3} \quad 17.56 \quad 17.42$

$\mathrm{Fe}_{2} \mathrm{O}_{3} \quad 9.72 \quad 9.64$

$\mathrm{MgO} \quad 4.41$

4.30

0.15

0.28

0.06

0.35

0.10

1.07

0.03

0.78

6.97

0.03

0.50

0.07

2.35

0.01

0.42

0.02

2.06

0.02

9.85

$\begin{array}{ll}- & 0.06\end{array}$

0.05

3.81

0.05

4.65

0.01

0.63

0.01

0.29

0.02

0.01

14.14

0.22

$390 \quad 338$

112.4

33.27

1400

1436

8.40

0.63

$\mathrm{Cr}$

42

46

$5.13 \quad 11.16$

55

64

2.12

3.31

$\mathrm{Zr}$

125

130

6.27

4.82

240

219

1.58

0.72

Sr $\quad 400 \quad 399$

2.1

0.55

570

608

3.81

0.63

Rb $\quad 70$

67

2.80

$4.18 \quad 190$

181

1.00

0.55

$\mathbf{Y}$

30

29

1.73

5.97

19

1.23

6.45

Nb 6

$\mathrm{Zn} \quad 145$

Ni

145

4

1.47

7.36

144

10.09

7.01

4.45

34.53

10.72

4.87

$230 \quad 220$

220

19

1.73

9.12

48

54

7.21

13.35

22

1.58

7.19

v

230

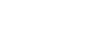


TABLE A 2.2

WHOLE-ROCK CHEMICAL DATA AND CIPW NORMS

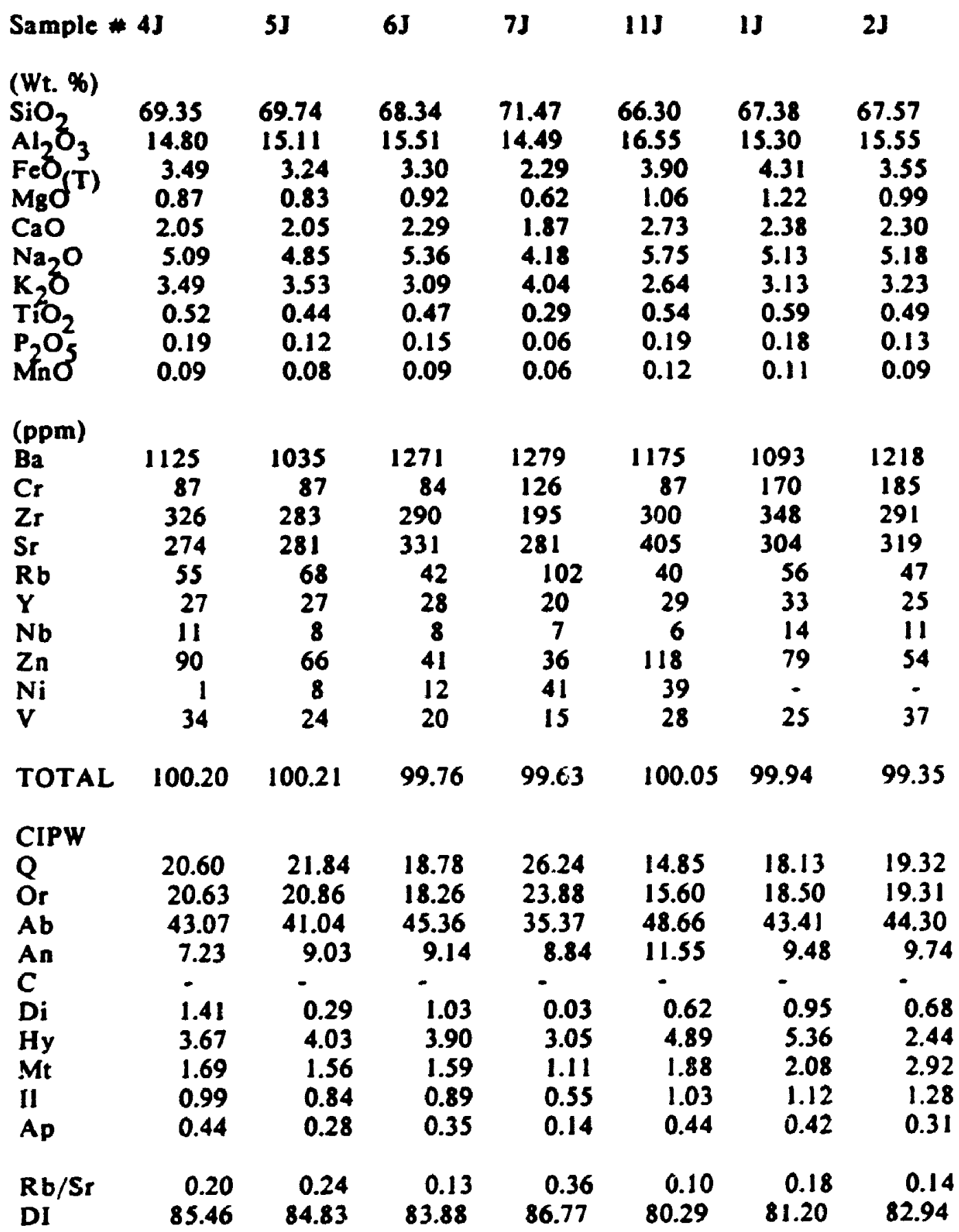

FeO $(T$ is total iron.

DI is Differentiation Index 


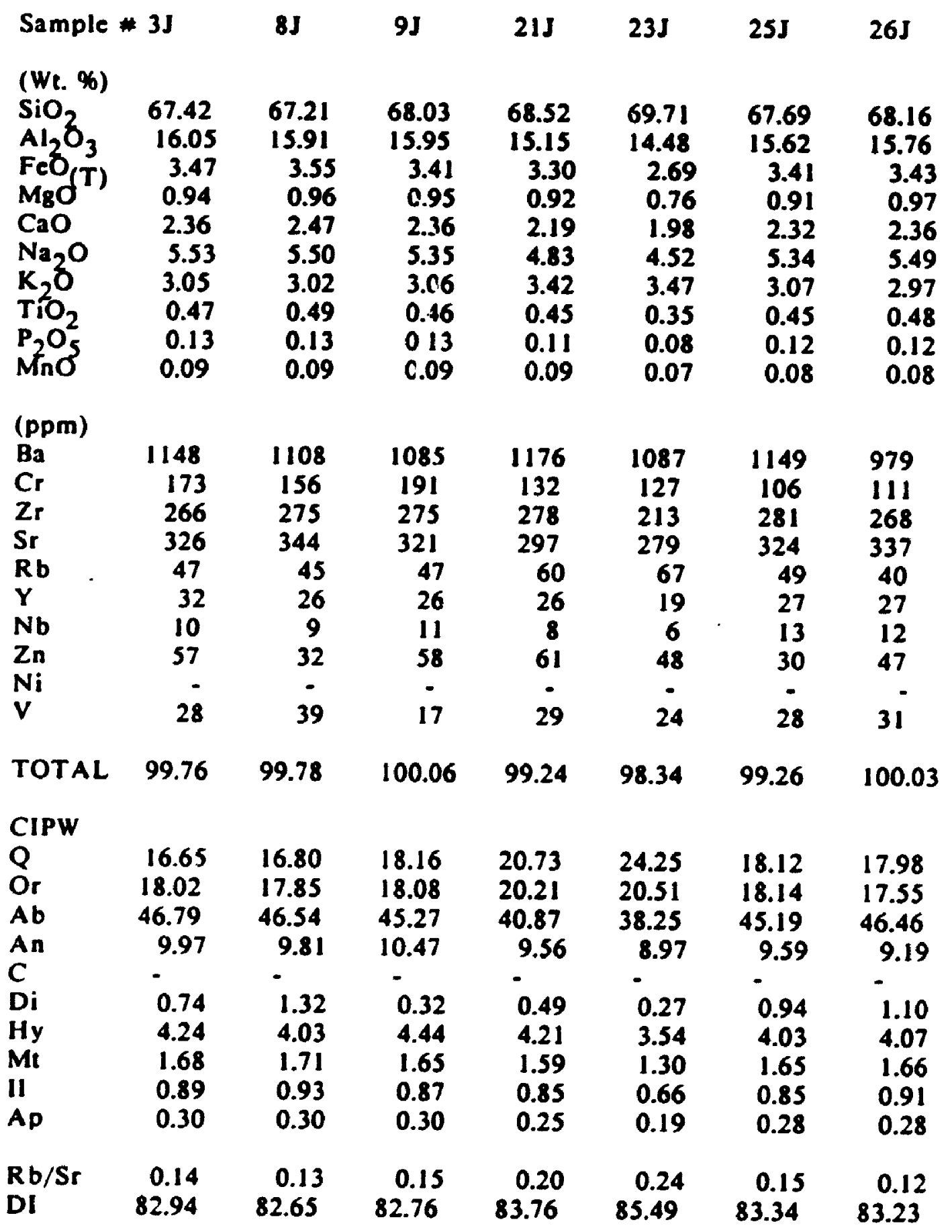




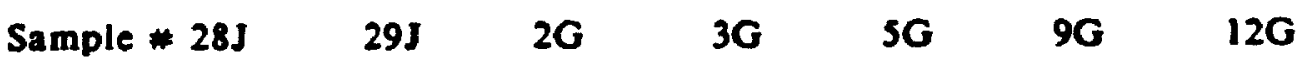

(Wt. \%)

$\begin{array}{lccccccr}\mathrm{SiO}_{2} & 68.64 & 69.14 & 56.67 & 61.75 & 62.08 & 60.27 & 63.89 \\ \mathrm{Al}_{2} \mathrm{O}_{3} & 15.17 & 15.52 & 18.11 & 17.09 & 16.94 & 16.63 & 16.46 \\ \mathrm{FeO}(\mathrm{T}) & 3.34 & .3 .27 & 7.85 & 7.36 & 6.28 & 7.35 & 5.61 \\ \mathrm{MgO} & 0.89 & 0.89 & 3.58 & 2.55 & 2.06 & 2.72 & 1.98 \\ \mathrm{CaO} & 2.12 & 1.95 & 7.22 & 5.34 & 4.97 & 5.62 & 4.67 \\ \mathrm{Na}_{2} \mathrm{O} & 5.02 & 5.36 & 3.92 & 3.37 & 3.80 & 3.58 & 3.61 \\ \mathrm{~K}_{2} \mathrm{O} & 3.39 & 3.40 & 1.50 & 2.49 & 2.62 & 2.36 & 2.79 \\ \mathrm{TiO}_{2} & 0.45 & 0.43 & 0.71 & 0.70 & 0.61 & 0.67 & 0.53 \\ \mathrm{P}_{2} \mathrm{O}_{5} & 0.12 & 0.12 & 0.22 & 0.16 & 0.14 & 0.17 & 0.14 \\ \mathrm{MnO}^{2} & 0.09 & 0.08 & 0.14 & 0.13 & 0.11 & 0.13 & 0.10\end{array}$

(ppm)

$\begin{array}{lrrrrrrr}\mathrm{Ba} & 1132 & 1116 & 767 & 1328 & 1666 & 1091 & 1068 \\ \mathrm{Cr} & 110 & 132 & 65 & 74 & 87 & 81 & 79 \\ \mathrm{Zr} & 268 & 251 & 102 & 212 & 186 & 124 & 241 \\ \mathrm{Sr} & 283 & 293 & 905 & 546 & 591 & 518 & 497 \\ \mathrm{Rb} & 56 & 58 & 29 & 59 & 64 & 51 & 69 \\ \mathrm{Y} & 28 & 29 & 21 & 28 & 24 & 32 & 29 \\ \mathrm{Nb} & 10 & 11 & - & 2 & - & - & 1 \\ \mathrm{Zn} & 35 & 60 & 74 & 76 & 68 & 86 & 65 \\ \mathrm{Ni} & - & - & 22 & 3 & - & - & 12 \\ \mathrm{~V} & 27 & 25 & 133 & 120 & 88 & 120 & 104\end{array}$

$\begin{array}{llllllll}\text { TOTAL } & 99.47 & 100.40 & 100.18 & 101.24 & 99.96 & 99.76 & 100.05\end{array}$

$\begin{array}{lccccccc}\text { CIPW } & & & & & & & \\ \text { Q } & 20.13 & 18.94 & 6.45 & 15.45 & 15.14 & 13.06 & 18.42 \\ \text { Or } & 20.03 & 20.09 & 8.86 & 14.67 & 15.48 & 13.95 & 16.49 \\ \text { Ab } & 42.48 & 45.36 & 33.17 & 28.40 & 32.15 & 30.29 & 30.55 \\ \text { An } & 8.85 & 8.25 & 27.39 & 24.05 & 21.43 & 22.34 & 20.47 \\ \text { C } & - & - & - & - & - & - & - \\ \text { Di } & 0.73 & 0.53 & 5.73 & 0.60 & 1.90 & 3.65 & 1.46 \\ \text { Hy } & 4.04 & 4.10 & 12.69 & 11.93 & 8.54 & 10.88 & 7.77 \\ \text { Mt } & 1.61 & 1.58 & 3.20 & 3.18 & 3.06 & 3.15 & 2.94 \\ \text { Il } & 0.85 & 0.82 & 1.35 & 1.34 & 1.16 & 1.27 & 1.01 \\ \text { Ap } & 0.28 & 0.28 & 0.51 & 0.37 & 0.32 & 0.39 & 0.32 \\ \text { Rb/Sr } & 0.19 & 0.19 & 0.03 & 0.08 & 0.11 & 0.10 & 0.14 \\ \text { DI } & 84.37 & 85.34 & 48.89 & 58.52 & 63.37 & 57.97 & 65.89\end{array}$


$\begin{array}{lllllll}\text { Sample } * 4 G \quad 6 G & 7 G & 10 G & 11 G & 1 H & 3 H\end{array}$

(Wt. \%)

$\begin{array}{lccccccc}\mathrm{SiO}_{2} & 60.88 & 60.12 & 59.40 & 62.48 & 56.64 & 55.22 & 58.89 \\ \mathrm{Al}_{2} \mathrm{O}_{3} & 17.01 & 16.89 & 17.30 & 16.42 & 16.78 & 18.96 & 17.23 \\ \mathrm{FeO}_{(\mathrm{T})} & 7.41 & 7.28 & 7.20 & 5.98 & 8.77 & 7.58 & 7.45 \\ \mathrm{Mg} & 2.53 & 2.74 & 2.63 & 2.37 & 4.35 & 3.61 & 3.32 \\ \mathrm{CaO} & 5.26 & 5.94 & 6.11 & 4.56 & 7.79 & 7.10 & 5.61 \\ \mathrm{Na}_{2} \mathrm{O} & 3.56 & 3.36 & 3.80 & 4.06 & 3.54 & 4.67 & 3.63 \\ \mathrm{~K}_{2} \mathrm{O} & 2.72 & 2.05 & 1.79 & 2.86 & 1.48 & 1.38 & 2.45 \\ \mathrm{TiO}_{2} & 0.65 & 0.56 & 0.59 & 0.70 & 0.69 & 0.91 & 0.80 \\ \mathrm{P}_{2} \mathrm{O}_{5} & 0.13 & 0.13 & 0.13 & 0.19 & 0.24 & 0.31 & 0.21 \\ \mathrm{MnO}_{n} & 0.13 & 0.13 & 0.12 & 0.10 & 0.18 & 0.14 & 0.13\end{array}$

(ppm)

$\begin{array}{lrrrrrrr}\mathrm{Ba} & 1306 & 826 & 790 & 896 & 676 & 633 & 775 \\ \mathrm{Cr} & 149 & 150 & 143 & 155 & 145 & 77 & 71 \\ \mathrm{Zr} & 173 & 106 & 119 & 236 & 87 & 203 & 132 \\ \mathrm{Sr} & 532 & 574 & 639 & 609 & 898 & 959 & 466 \\ \mathrm{Rb} & 63 & 42 & 44 & 80 & 27 & 28 & 70 \\ \mathrm{Y} & 29 & 23 & 21 & 25 & 17 & 23 & 24 \\ \mathrm{Nb} & 1 & 2 & 3 & 8 & 4 & 4 & 8 \\ \mathrm{Zn} & 73 & 71 & 74 & 77 & 64 & 103 & 92 \\ \mathrm{Ni} & - & - & 7 & 1 & 8 & 35 & 34 \\ \mathrm{~V} & 145 & 125 & 124 & 99 & 181 & 137 & 143\end{array}$

$\begin{array}{llllllll}\text { TOTAL } & 100.58 & 99.44 & 99.32 & 99.96 & 100.72 & 100.17 & 99.96\end{array}$

CIPW

$\begin{array}{lrrrrrrr}\text { Q } & 13.03 & 14.23 & 12.07 & 14.27 & 6.62 & 2.04 & 10.14 \\ \text { Or } & 16.13 & 12.12 & 10.58 & 16.90 & 8.75 & 8.16 & 14.48 \\ \text { Ab } & 30.20 & 28.43 & 32.15 & 34.35 & 29.95 & 39.52 & 30.72 \\ \text { An } & 22.46 & 24.95 & 24.86 & 18.13 & 25.53 & 26.70 & 23.49 \\ \text { C } & - & - & - & - & - & - & - \\ \text { Di } & 1.30 & 3.03 & 3.79 & 2.64 & 9.47 & 5.29 & 2.43 \\ \text { Hy } & 12.13 & 11.57 & 10.64 & 8.08 & 14.44 & 11.73 & 12.61 \\ \text { Mt } & 3.13 & 2.99 & 3.03 & 3.19 & 3.18 & 3.49 & 3.33 \\ \text { II } & 1.26 & 1.06 & 1.12 & 1.33 & 1.31 & 1.73 & 1.52 \\ \text { Ap } & 0.30 & 0.30 & 0.30 & 0.44 & 0.56 & 0.72 & 0.49 \\ \text { R b/Sr } & 0.14 & 0.07 & 0.07 & 0.13 & 0.03 & 0.03 & 0.15 \\ \text { DI } & 59.36 & 55.60 & 55.70 & 66.02 & 45.49 & 50.11 & 55.85\end{array}$




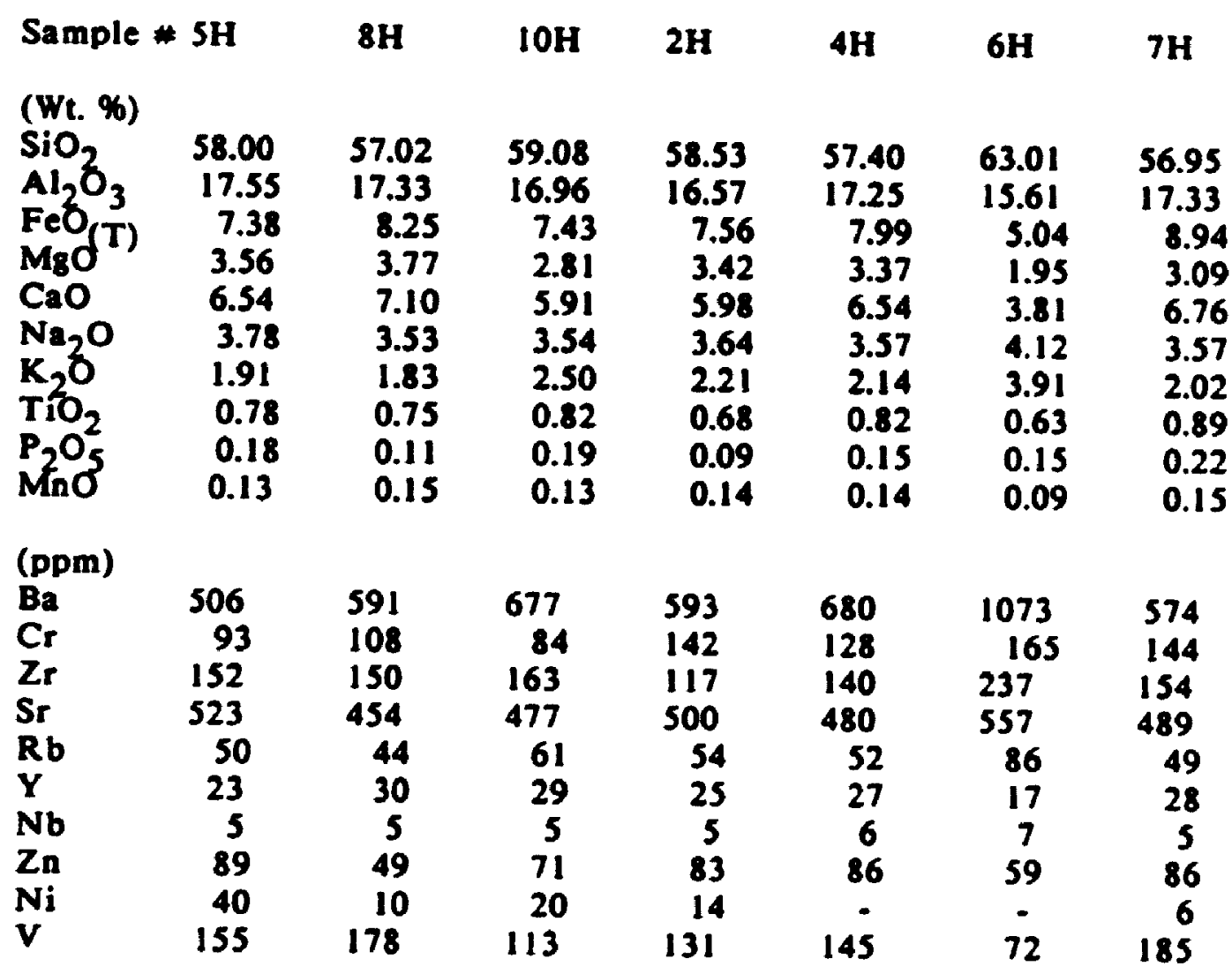

$\begin{array}{llllllll}\text { TOTAL } & 100.03 & 100.04 & 99.58 & 99.04 & 99.60 & 98.60 & 100.14\end{array}$

$\begin{array}{lrrrrrrr}\text { CIPW } & & & & & & & \\ \text { Q } & 8.68 & 7.56 & 11.23 & 9.86 & 8.39 & 13.0 & 8.09 \\ \text { Or } & 11.29 & 10.81 & 14.77 & 13.06 & 12.65 & 23.11 & 12.04 \\ \text { Ab } & 31.99 & 29.87 & 29.95 & 30.80 & 30.21 & 34.86 & 30.44 \\ \text { An } & 25.28 & 26.04 & 23.01 & 22.35 & 24.73 & 12.55 & 25.49 \\ \text { C } & - & - & - & - & - & - & - \\ \text { Di } & 4.88 & 6.94 & 4.16 & 5.51 & 5.53 & 4.39 & 5.66 \\ \text { Hy } & 11.99 & 13.08 & 10.37 & 12.04 & 12.04 & 6.01 & 12.52 \\ \text { Mt } & 3.31 & 3.26 & 3.36 & 3.16 & 3.36 & 2.43 & 3.49 \\ \text { II } & 1.48 & 1.42 & 1.56 & 1.29 & 1.56 & 1.20 & 1.70 \\ \text { Ap } & 0.42 & 0.25 & 0.44 & 0.21 & 0.35 & 0.35 & 0.51 \\ \text { Rb/Sr } & 0.09 & 0.09 & 0.13 & 0.11 & 0.11 & 0.15 & 0.09 \\ \text { DI } & 52.38 & 48.69 & 56.68 & 54.75 & 51.94 & 73.05 & 50.57\end{array}$




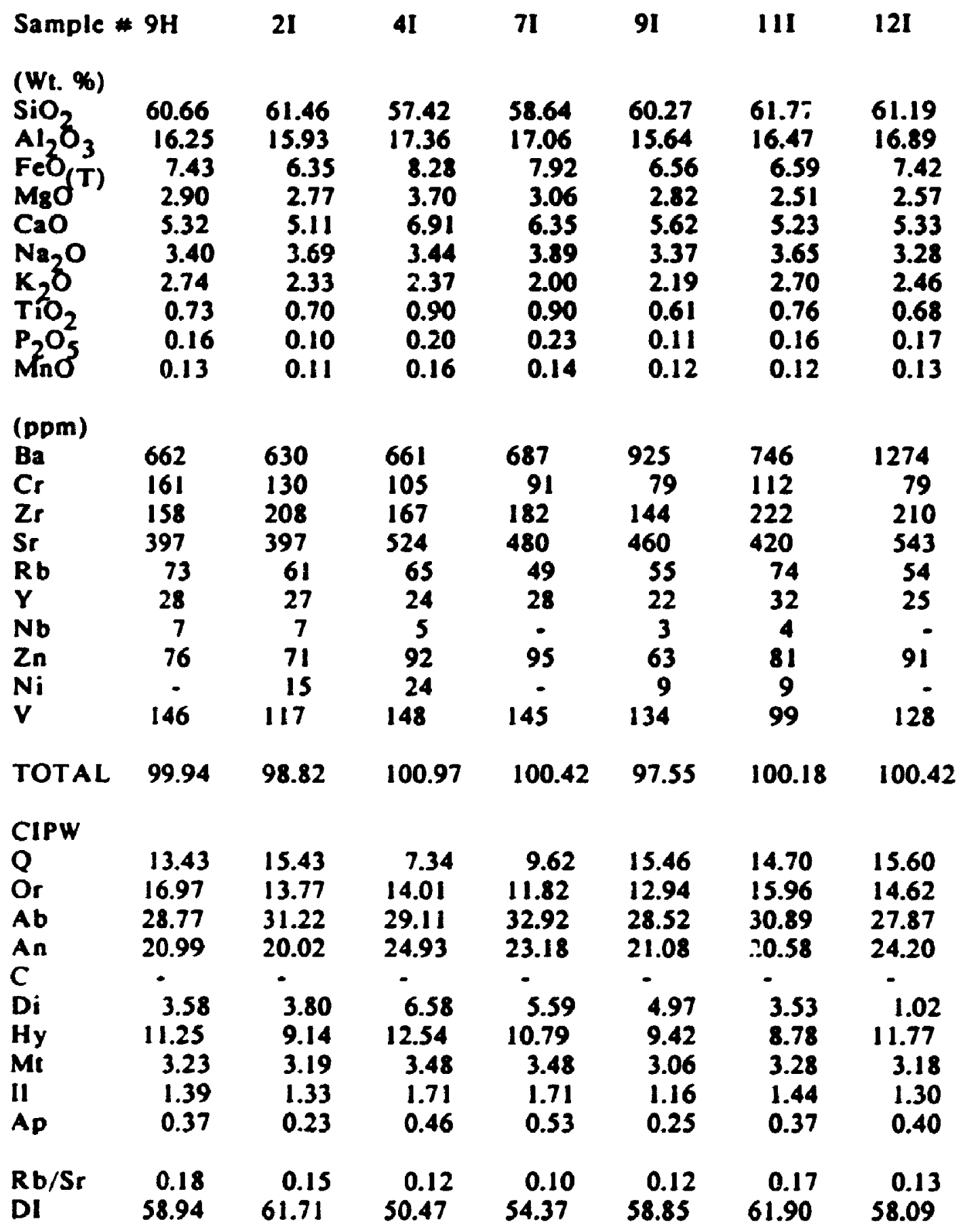




\begin{tabular}{|c|c|c|c|c|c|c|c|}
\hline Sample & $5 I$ & ID & 2D & $3 D$ & 4D & SD & 6D \\
\hline 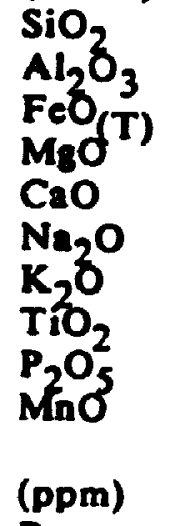 & $\begin{array}{c}58.20 \\
17.65 \\
8.35 \\
3.88 \\
7.31 \\
3.53 \\
1.87 \\
0.76 \\
0.08 \\
0.15\end{array}$ & $\begin{array}{c}46.17 \\
17.75 \\
11.87 \\
6.60 \\
12.31 \\
2.23 \\
0.55 \\
1.06 \\
0.11 \\
0.18\end{array}$ & $\begin{array}{c}48.09 \\
12.21 \\
8.47 \\
9.68 \\
19.44 \\
0.81 \\
0.03 \\
0.30 \\
- \\
0.15\end{array}$ & $\begin{array}{r}50.55 \\
18.88 \\
7.32 \\
8.66 \\
9.71 \\
2.61 \\
0.24 \\
0.46 \\
- \\
0.12\end{array}$ & $\begin{array}{c}55.29 \\
16.91 \\
8.29 \\
5.27 \\
6.54 \\
3.94 \\
1.61 \\
1.23 \\
0.21 \\
0.15\end{array}$ & $\begin{array}{c}47.27 \\
22.13 \\
4.52 \\
10.11 \\
9.90 \\
2.64 \\
0.37 \\
0.07 \\
- \\
0.06\end{array}$ & $\begin{array}{l}49.58 \\
10.34 \\
11.77 \\
11.86 \\
12.39 \\
1.48 \\
0.43 \\
0.63 \\
0.03 \\
0.23\end{array}$ \\
\hline $\begin{array}{l}\mathrm{Ba} \\
\mathrm{Cr} \\
\mathrm{Zr} \\
\mathrm{Sr} \\
\mathrm{R} \mathbf{b} \\
\mathbf{Y} \\
\mathrm{Nb} \\
\mathbf{Z} \mathbf{n} \\
\mathrm{Ni}\end{array}$ & $\begin{array}{c}654 \\
114 \\
117 \\
463 \\
43 \\
28 \\
4 \\
87 \\
16 \\
191\end{array}$ & $\begin{array}{r}246 \\
69 \\
102 \\
999 \\
3 \\
17 \\
3 \\
84 \\
25 \\
364\end{array}$ & $\begin{array}{c}92 \\
608 \\
12 \\
311 \\
- \\
12 \\
1 \\
8 \\
93 \\
322\end{array}$ & $\begin{array}{c}141 \\
298 \\
28 \\
475 \\
11 \\
- \\
60 \\
159 \\
110\end{array}$ & $\begin{array}{r}453 \\
140 \\
124 \\
633 \\
21 \\
19 \\
5 \\
83 \\
69 \\
129\end{array}$ & $\begin{array}{r}147 \\
202 \\
8 \\
573 \\
8 \\
3 \\
- \\
45 \\
372 \\
28\end{array}$ & $\begin{array}{r}180 \\
231 \\
41 \\
412 \\
3 \\
22 \\
- \\
105 \\
109 \\
141\end{array}$ \\
\hline TOTAL & 01.99 & 99.18 & 99.52 & 98.79 & 99.66 & 97.25 & 98.98 \\
\hline $\begin{array}{l}Q \\
\text { Or } \\
A \mathbf{b} \\
\text { An }\end{array}$ & $\begin{array}{r}7.91 \\
10.94 \\
29.53 \\
26.49\end{array}$ & $\begin{array}{c}3.32 \\
19.28 \\
37.61\end{array}$ & $\begin{array}{r}2.26 \\
23.07 \\
49.00\end{array}$ & $\begin{array}{r}1.45 \\
23.12 \\
39.53\end{array}$ & $\begin{array}{c}4.32 \\
9.63 \\
33.72 \\
23.97\end{array}$ & $\begin{array}{r}2.26 \\
23.07 \\
49.00\end{array}$ & $\begin{array}{r}4.03 \\
2.54 \\
12.52 \\
20.30\end{array}$ \\
\hline $\begin{array}{l}\text { C } \\
\text { Di } \\
\text { Hy } \\
\text { Mt } \\
\text { II } \\
\text { Ap }\end{array}$ & $\begin{array}{r}- \\
7.24 \\
12.97 \\
3.24 \\
1.43 \\
0.18\end{array}$ & $\begin{array}{c}19.57 \\
13.41 \\
3.79 \\
1.52 \\
0.26\end{array}$ & $\begin{array}{c}1.36 \\
18.99 \\
2.35 \\
0.14 \\
\cdot\end{array}$ & $\begin{array}{c}7.65 \\
22.60 \\
2.90 \\
0.89 \\
-\end{array}$ & $\begin{array}{c}5.98 \\
15.39 \\
4.00 \\
1.72 \\
0.49\end{array}$ & $\begin{array}{c}1.35 \\
21.56 \\
2.35 \\
0.14 \\
\end{array}$ & $\begin{array}{c}30.89 \\
15.22 \\
3.77 \\
0.49 \\
0.07\end{array}$ \\
\hline $\mathrm{b} / \mathrm{Sr}$ & $\begin{array}{r}0.09 \\
48.38\end{array}$ & $\begin{array}{r}0.01 \\
22.60\end{array}$ & 6.76 & 24.56 & $\begin{array}{r}0.03 \\
47.66\end{array}$ & $\begin{array}{r}0.01 \\
25.33\end{array}$ & $\begin{array}{r}0.01 \\
19.09\end{array}$ \\
\hline
\end{tabular}


Sample *7D $\quad 8 D \quad 9 D \quad$ IOD $\quad 110 \quad 120 \quad 1 A$

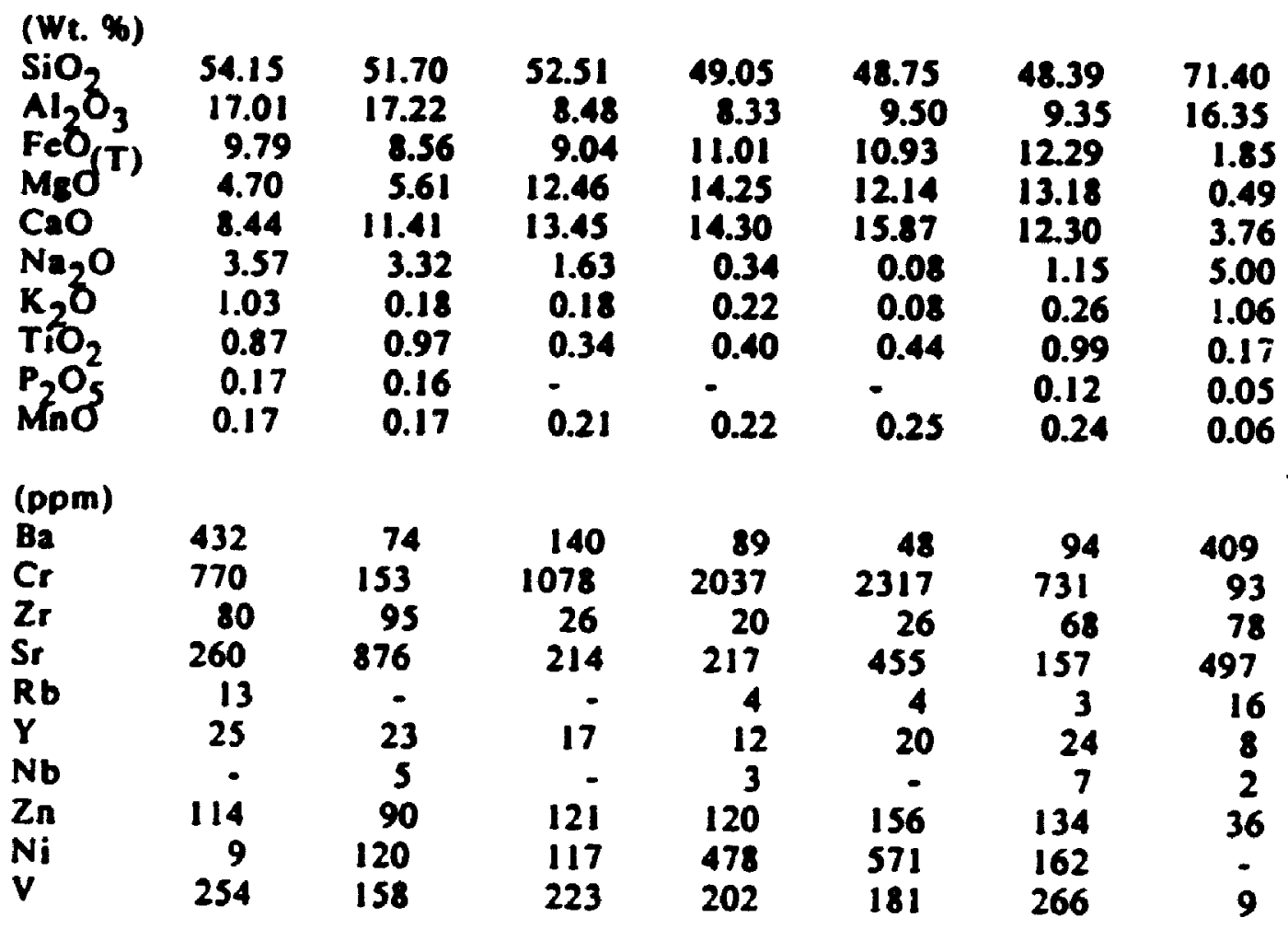

$\begin{array}{llllllll}\text { TOTAL } 100.11 & 99.51 & 98.59 & 98.58 & 98.57 & 98.49 & 100.34\end{array}$

$\begin{array}{lccccc}\text { CIPW } & & & & & \\ \text { Q } & 7.73 & 4.52 & 6.03 & 5.23 & 28.99 \\ \text { Or } & 6.09 & 1.06 & 1.06 & 1.30 & 6.26 \\ \text { Ab } & 30.21 & 28.09 & 13.79 & 2.88 & 42.31 \\ \text { An } & 27.35 & 31.55 & 15.29 & 20.55 & 18.33 \\ \text { C } & - & - & - & - & 0.26 \\ \text { Di } & 8.60 & 16.58 & 29.76 & 28.81 & - \\ \text { Hy } & 12.72 & 10.29 & 22.65 & 27.49 & 2.58 \\ \text { Mt } & 4.79 & 4.56 & 9.04 & 11.01 & 0.89 \\ \text { II } & 0.36 & 0.36 & 0.45 & 0.47 & 0.32 \\ \text { Ap } & 0.39 & 0.37 & 0.25 & - & 0.12 \\ \text { Rb/Sr } & 0.03 & - & - & 0.02 & 0.03 \\ \text { DI } & 44.03 & 33.67 & 20.88 & 9.41 & 77.56\end{array}$




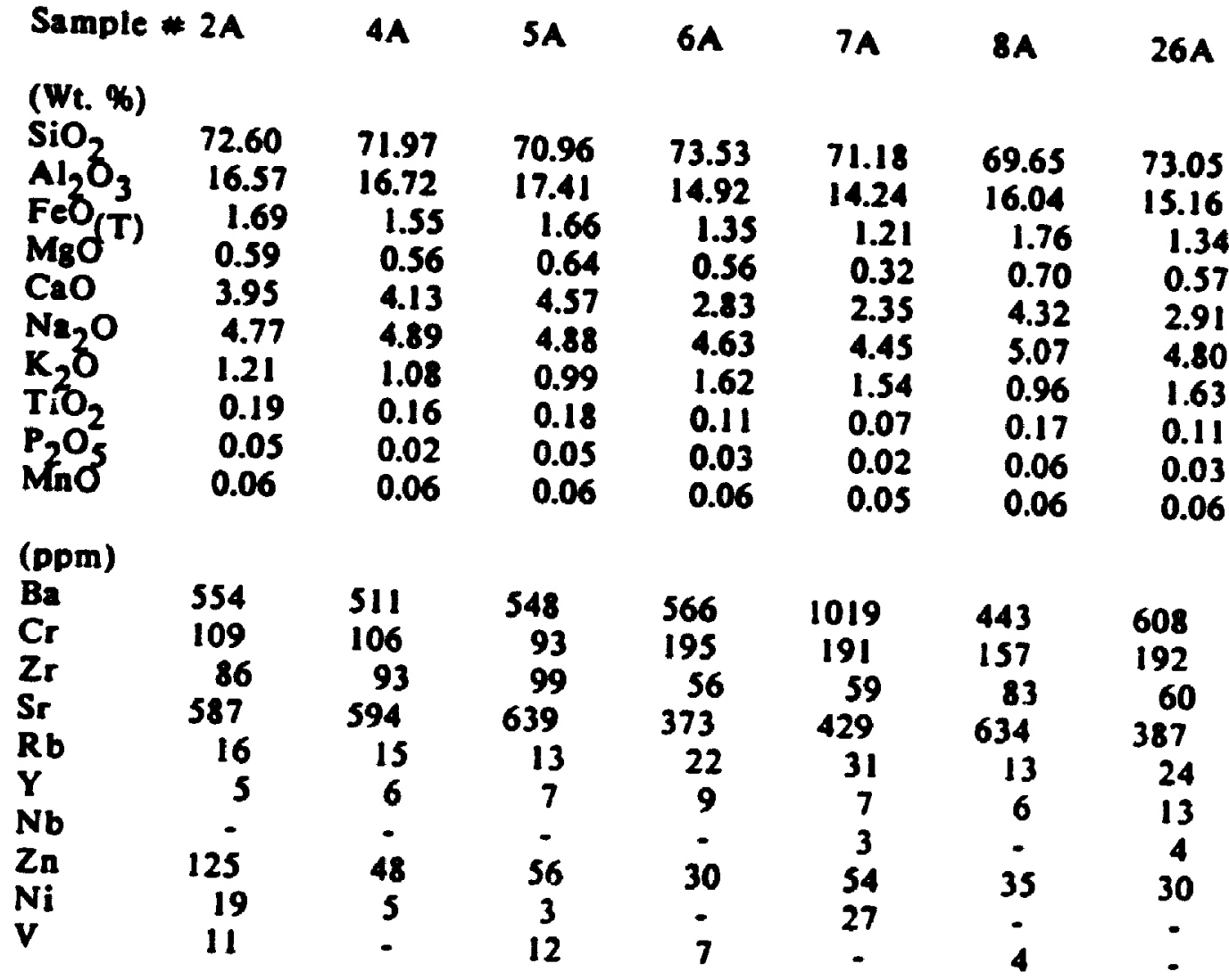

$\begin{array}{llllllll}\text { TOTAL } & 101.86 & 101.30 & 101.57 & 97.80 & 96.85 & 99.95 & 99.83\end{array}$

$\begin{array}{lccccccc}\text { CIPW } & & & & & & & \\ \text { Q } & 30.47 & 29.25 & 27.64 & 33.11 & 33.70 & 26.39 & 31.42 \\ \text { Or } & 7.15 & 6.38 & 5.85 & 9.57 & 9.10 & 5.67 & 9.63 \\ \text { Ab } & 40.36 & 41.38 & 41.29 & 39.18 & 37.66 & 42.90 & 40.62 \\ \text { An } & 19.27 & 20.36 & 2.35 & 13.84 & 11.53 & 18.18 & 14.24 \\ \text { C } & 0.35 & 0.05 & 0.12 & 0.48 & 1.03 & - & 0.28 \\ \text { Di } & - & - & - & - & - & 2.35 & - \\ \text { Hy } & 2.67 & 2.52 & 2.78 & 2.44 & 1.78 & 1.88 & 2.46 \\ \text { Mt } & 0.82 & 0.75 & 0.80 & 0.65 & 0.58 & 0.85 & 0.65 \\ \text { II } & 0.36 & 0.30 & 0.34 & 0.21 & 0.13 & 0.32 & 0.21 \\ \text { Ap } & 0.12 & 0.05 & 0.12 & 0.07 & 0.05 & 0.14 & 0.07\end{array}$

$\begin{array}{lrrrrrrr}\mathrm{Rb} / \mathrm{Sr} & 0.03 & 0.03 & 0.02 & 0.06 & 0.07 & 0.02 & 0.06 \\ \mathrm{DI} & 77.98 & 77.04 & 74.78 & 81.86 & 80.46 & 74.96 & 81.67\end{array}$




\begin{tabular}{|c|c|c|c|c|c|c|c|}
\hline \multicolumn{8}{|c|}{$\begin{array}{l}\text { Sample \#27A } \\
(W t . \%)\end{array}$} \\
\hline $\begin{array}{l}\mathrm{SiO}_{2} \\
\mathrm{Al}_{2} \mathrm{O}_{3} \\
\mathrm{FeO}_{3}(\mathrm{~T}) \\
\mathrm{Mg}_{8} \mathrm{O} \\
\mathrm{CaO} \\
\mathrm{Na}_{2} \mathrm{O} \\
\mathrm{K}_{2} \mathrm{O} \\
\mathrm{TiO}_{2} \\
\mathrm{P}_{2} \mathrm{O}_{5} \\
\mathrm{MnO}^{-}\end{array}$ & $\begin{array}{l}74.11 \\
14.74 \\
1.17 \\
0.32 \\
2.41 \\
4.71 \\
1.58 \\
0.07 \\
0.02 \\
0.06\end{array}$ & $\begin{array}{l}71.59 \\
14.66 \\
4.06 \\
0.60 \\
1.115 \\
3.19 \\
4.80 \\
0.49 \\
0.13 \\
0.49\end{array}$ & $\begin{array}{r}70.33 \\
14.38 \\
4.18 \\
0.62 \\
1.88 \\
3.73 \\
4.84 \\
0.48 \\
0.15 \\
0.08\end{array}$ & $\begin{array}{r}73.09 \\
14.16 \\
2.20 \\
0.19 \\
0.81 \\
5.14 \\
4.18 \\
0.13 \\
0.01 \\
0.06\end{array}$ & $\begin{array}{r}69.16 \\
14.31 \\
4.24 \\
0.67 \\
2.14 \\
3.91 \\
4.64 \\
0.52 \\
0.12 \\
0.08\end{array}$ & $\begin{array}{r}71.08 \\
14.24 \\
4.06 \\
0.52 \\
1.78 \\
3.89 \\
4.80 \\
0.45 \\
0.10 \\
0.08\end{array}$ & $\begin{array}{r}69.18 \\
14.12 \\
4.20 \\
0.67\end{array}$ \\
\hline \multicolumn{8}{|l|}{ (ppm) } \\
\hline $\begin{array}{l}\mathrm{Ba} \\
\mathrm{Cr} \\
\mathrm{Zr} \\
\mathrm{Sr} \\
\mathrm{R} \mathbf{b}\end{array}$ & $\begin{array}{r}1038 \\
180 \\
59 \\
436 \\
30\end{array}$ & $\begin{array}{l}921 \\
117 \\
379 \\
207 \\
170\end{array}$ & $\begin{array}{r}1000 \\
92 \\
361 \\
215 \\
172\end{array}$ & $\begin{array}{c}333 \\
81 \\
244 \\
170 \\
211\end{array}$ & $\begin{array}{l}960 \\
98 \\
386 \\
222 \\
172\end{array}$ & $\begin{array}{r}1032 \\
110 \\
361 \\
200\end{array}$ & $\begin{array}{l}904 \\
165 \\
354 \\
209 \\
163\end{array}$ \\
\hline $\mathbf{Y}$ & 7 & 67 & 59 & 59 & 62 & $\begin{array}{r}184 \\
61\end{array}$ & $\begin{array}{c}103 \\
6 n\end{array}$ \\
\hline $\begin{array}{l}\text { Nb } \\
\mathrm{Zn}_{\mathbf{n}}\end{array}$ & $29^{3}$ & $\begin{array}{l}25 \\
91\end{array}$ & $\begin{array}{l}22 \\
65\end{array}$ & $\begin{array}{l}55 \\
62\end{array}$ & $\begin{array}{l}25 \\
58\end{array}$ & $\begin{array}{l}28 \\
72\end{array}$ & $\begin{array}{l}25 \\
91\end{array}$ \\
\hline $\mathbf{N i}$ & - & 22 & 18 & 10 & 24 & 22 & . \\
\hline $\mathbf{V}$ & 5 & 7 & 27 & - & 10 & 25 & 3 \\
\hline
\end{tabular}

$\begin{array}{llllllll}\text { TOTAL } & 99.41 & 102.31 & 100.91 & 100.12 & 100.05 & 101.27 & 99.76\end{array}$

$\begin{array}{lrrrrrrr}\text { CIPW } & & & & & & & \\ \text { Q } & 31.99 & 25.69 & 24.89 & 25.37 & 23.39 & 25.23 & 23.14 \\ \text { Or } & 9.67 & 27.88 & 28.50 & 24.74 & 27.57 & 28.17 & 28.65 \\ \text { Ab } & 40.74 & 31.48 & 31.42 & 43.52 & 33.23 & 32.65 & 33.57 \\ \text { An } & 14.28 & 8.18 & 8.15 & 3.21 & 7.81 & 7.15 & 6.67 \\ \text { C } & 0.28 & 0.17 & - & - & - & - & - \\ \text { Di } & - & - & 0.13 & 0.58 & 1.68 & 0.79 & 1.45 \\ \text { Hy } & 1.42 & 2.52 & 2.77 & 0.21 & 2.05 & 2.07 & 2.24 \\ \text { Mt } & 1.34 & 2.83 & 2.86 & 2.04 & 2.94 & 2.81 & 2.86 \\ \text { II } & 0.09 & 0.91 & 0.92 & 0.25 & 0.99 & 0.85 & 0.88 \\ \text { Ap } & 0.07 & 0.29 & 0.35 & 0.02 & 0.28 & 0.23 & 0.37 \\ \text { Rb/Sr } & 0.06 & 0.82 & 0.80 & 1.24 & 0.77 & 0.92 & 0.78 \\ \text { DI } & 81.39 & 85.05 & 84.88 & 93.64 & 84.18 & 86.05 & 85.36\end{array}$




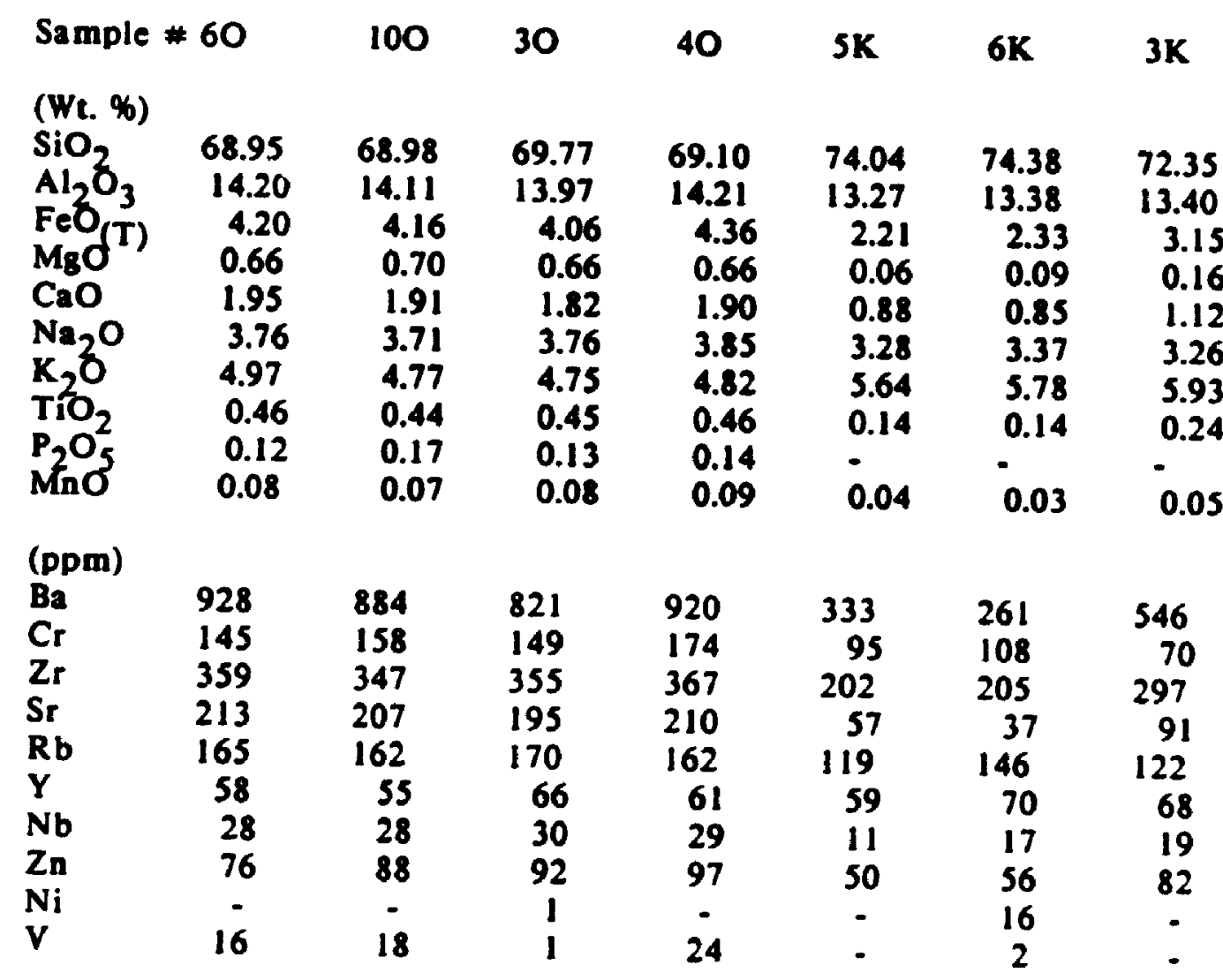

$\begin{array}{llllllll}\text { TOTAL } & 99.59 & 99.26 & 99.70 & 99.83 & 99.67 & 100.46 & 99.83\end{array}$

$\begin{array}{lccccccc}\text { CIPW } & & & & & & & \\ \text { Q } & 23.15 & 24.25 & 25.03 & 23.24 & 29.81 & 30.59 & 28.62 \\ \text { Or } & 29.66 & 28.56 & 28.31 & 28.70 & 33.54 & 34.09 & 35.17 \\ \text { Ab } & 32.09 & 31.77 & 32.06 & 32.79 & 30.81 & 28.43 & 27.56 \\ \text { An } & 7.24 & 7.84 & 7.26 & 7.29 & 2.62 & 4.21 & 4.10 \\ \text { C } & - & - & - & - & - & 0.03 & - \\ \text { Di } & 1.41 & 0.51 & 0.79 & 1.04 & 0.53 & - & 1.15 \\ \text { Hy } & 2.38 & 2.93 & 2.48 & 2.82 & 0.42 & 0.22 & 0.40 \\ \text { Mt } & 2.87 & 2.85 & 2.85 & 2.86 & 1.06 & 1.58 & 2.48 \\ \text { II } & 0.88 & 0.85 & 0.86 & 0.88 & 0.26 & 0.27 & 0.45 \\ \text { Ap } & 0.28 & 0.40 & 0.30 & 0.33 & 0.02 & - & 0.02 \\ \text { Rb/Sr } & 0.77 & 0.79 & 0.87 & 0.77 & 2.12 & 1.32 & 1.36 \\ \text { DI } & 84.90 & 84.58 & 85.40 & 86.73 & 94.15 & 93.10 & 91.35\end{array}$


$\begin{array}{llllllll}\text { Sample } & 4 \mathrm{~K} & 7 \mathrm{~K} & 8 \mathrm{~K} & 10 \mathrm{~K} & 11 \mathrm{~K} & 2 \mathrm{~L} & 6 \mathrm{~L}\end{array}$

(Wt. \%)

$\begin{array}{lccccccc}\mathrm{SiO}_{2} & 79.10 & 76.70 & 76.05 & 75.63 & 76.53 & 68.92 & 67.02 \\ \mathrm{Al}_{2} \mathrm{O}_{3} & 10.41 & 13.56 & 12.51 & 13.15 & 12.61 & 13.53 & 13.98 \\ \mathrm{FeO}_{(\mathrm{T}} \mathrm{T} & 1.72 & 2.27 & 1.98 & 1.93 & 1.62 & 5.36 & 5.68 \\ \mathrm{Mg} & 0.09 & 0.08 & 0.07 & 0.11 & 0.09 & 0.66 & 0.98 \\ \mathrm{CaO} & 0.69 & 0.81 & 0.77 & 0.96 & 0.73 & 2.20 & 2.49 \\ \mathrm{Na}_{2} \mathrm{O} & 2.74 & 3.40 & 3.38 & 3.60 & 3.29 & 3.30 & 3.58 \\ \mathrm{~K}_{2} \mathrm{O} & 4.14 & 5.94 & 5.07 & 5.17 & 5.35 & 4.80 & 4.53 \\ \mathrm{TiO}_{2} & 0.10 & 0.15 & 0.11 & 0.12 & 0.10 & 0.68 & 0.74 \\ \mathrm{P}_{2} \mathrm{O}_{5} & - & - & - & - & - & 0.29 & 0.25 \\ \mathrm{MnO}^{2} & 0.03 & 0.03 & 0.03 & 0.03 & 0.02 & 0.09 & 0.09\end{array}$

$\begin{array}{lccccccc}\text { (ppm) } & & & & & & & \\ \mathrm{Ba} & 296 & 294 & 175 & 240 & 275 & 954 & 1120 \\ \mathrm{Cr} & 140 & 98 & 107 & 108 & 123 & 65 & 57 \\ \mathrm{Zr} & 226 & 239 & 193 & 207 & 196 & 338 & 442 \\ \mathrm{Sr} & 38 & 52 & 32 & 45 & 42 & 227 & 245 \\ \mathrm{Rb} & 92 & 129 & 119 & 118 & 120 & 101 & 89 \\ \mathrm{Y} & 52 & 56 & 45 & 53 & 37 & 68 & 70 \\ \mathrm{Nb} & 12 & 10 & 12 & 12 & 9 & 26 & 23 \\ \mathrm{Zn} & 49 & 55 & 56 & 58 & 27 & 96 & 98 \\ \mathrm{Ni} & - & - & - & - & 13 & 29 & 30 \\ \mathrm{~V} & 11 & 2 & - & 6 & - & 9 & 20\end{array}$

$\begin{array}{llllllll}\text { TOTAL } & 99.12 & 99.44 & 100.07 & 100.12 & 100.46 & 100.05 & 99.61\end{array}$

$\begin{array}{lccccccc}\text { CIPW } & & & & & & & \\ \text { Q } & 46.11 & 31.40 & 36.28 & 32.51 & 35.07 & 25.72 & 22.18 \\ \text { Or } & 24.68 & 34.15 & 29.62 & 30.37 & 31.53 & 28.54 & 27.07 \\ \text { Ab } & 23.78 & 27.96 & 27.99 & 30.25 & 27.74 & 28.06 & 30.60 \\ \text { An } & 3.25 & 3.91 & 3.72 & 4.41 & 3.61 & 7.96 & 8.78 \\ \text { C } & 0.11 & 0.06 & 0.06 & - & 0.07 & - & - \\ \text { Di } & - & - & - & 0.25 & - & 0.92 & 1.63 \\ \text { Hy } & 0.24 & 0.19 & 0.34 & 0.16 & 0.22 & 3.63 & 4.35 \\ \text { Mt } & 0.07 & 1.31 & 0.50 & 0.54 & - & 3.18 & 3.28 \\ \text { II } & 0.19 & 0.28 & 0.21 & 0.23 & 0.02 & 1.30 & 1.42 \\ \text { Ap } & 0.05 & 0.03 & - & - & - & 0.68 & 0.59 \\ \text { Rb/Sr } & 2.29 & 2.53 & 3.85 & 2.68 & 2.86 & 0.45 & 0.36 \\ \text { Di } & 94.56 & 99.44 & 93.89 & 93.13 & 94.34 & 82.31 & 79.86\end{array}$




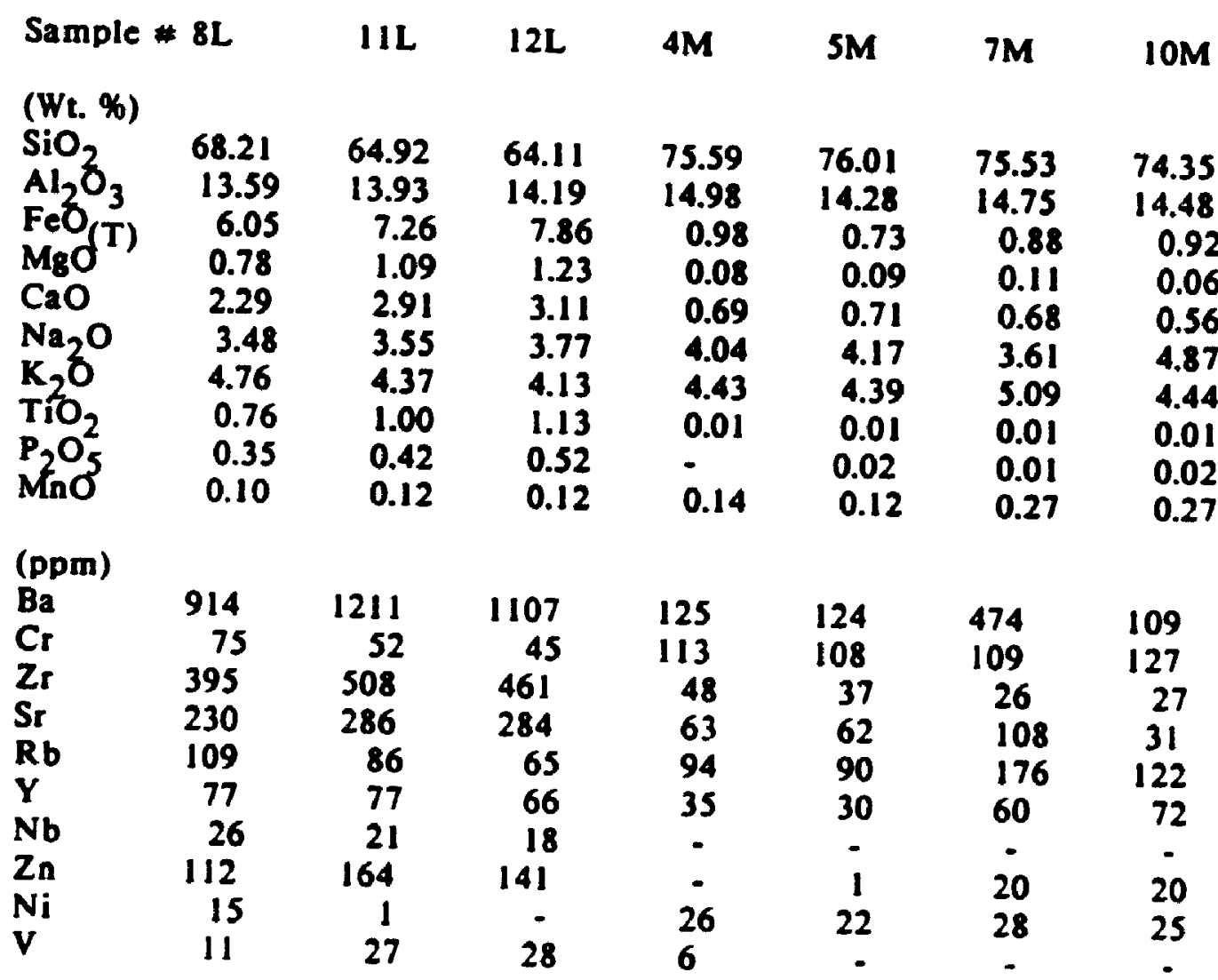

$\begin{array}{llllllll}\text { TOTAL } 100.62 & 99.86 & 98.93 & 100.99 & 100.59 & 101.07 & 100.81\end{array}$

$\begin{array}{lccccccc}\text { CIPW } & & & & & & & \\ \text { Q } & 23.54 & 19.64 & 17.68 & 33.20 & 33.14 & 33.12 & 27.79 \\ \text { Or } & 28.17 & 26.09 & 24.43 & 25.95 & 25.82 & 29.82 & 26.28 \\ \text { Ab } & 29.45 & 30.32 & 31.87 & 33.85 & 35.09 & 30.25 & 41.18 \\ \text { An } & 7.39 & 9.24 & 9.62 & 3.39 & 3.37 & 3.28 & 2.65 \\ \text { C } & - & - & - & 2.26 & 1.41 & 2.07 & 0.75 \\ \text { Di } & 1.40 & 2.14 & 2.00 & - & - & - & - \\ \text { Hy } & 3.47 & 5.97 & 6.86 & - & - & - & - \\ \text { Mt } & 3.28 & 3.66 & 4.11 & 0.34 & 0.27 & 0.76 & 0.55 \\ \text { II } & 1.44 & 1.92 & 2.16 & 0.02 & 0.02 & 0.02 & 0.01 \\ \text { Ap } & 0.81 & 0.98 & 1.21 & - & 0.05 & 0.02 & 0.04 \\ \text { Rb/Sr } & 0.48 & 0.30 & 0.23 & 1.50 & 1.48 & 1.64 & 3.95 \\ \text { DI } & 81.16 & 76.06 & 73.99 & 93.01 & 94.06 & 93.19 & 95.25\end{array}$




\begin{tabular}{|c|c|c|c|c|c|c|c|}
\hline Sample & I IM & $12 M$ & $13 \mathrm{M}$ & $16 M$ & $18 \mathrm{M}$ & $19 \mathrm{M}$ & IF \\
\hline (Wt. \%) & & & & & & & \\
\hline $\begin{array}{l}\mathrm{SiO}_{2} \\
\mathrm{Al}_{2} \mathrm{O}_{3} \\
\mathrm{FeO}_{(\mathrm{T})} \\
\mathrm{M}_{8} \mathrm{O} \\
\mathrm{CaO} \\
\mathrm{Na}_{2} \mathrm{O} \\
\mathrm{K}_{2} \mathrm{O} \\
\mathrm{TiO}_{2} \\
\mathrm{P}_{2} \mathrm{O}_{5} \\
\mathrm{MnO}^{-}\end{array}$ & $\begin{array}{c}75.41 \\
14.54 \\
0.72 \\
0.04 \\
0.41 \\
4.48 \\
4.39 \\
0.01 \\
0.04 \\
0.11\end{array}$ & $\begin{array}{r}74.61 \\
14.68 \\
0.99 \\
0.18 \\
0.67 \\
4.19 \\
4.14 \\
0.01 \\
0.04 \\
0.32\end{array}$ & $\begin{array}{r}73.76 \\
14.68 \\
1.01 \\
0.17 \\
0.74 \\
4.11 \\
4.14 \\
0.01 \\
- \\
0.32\end{array}$ & $\begin{array}{c}73.43 \\
14.97 \\
0.92 \\
0.17 \\
0.64 \\
3.94 \\
4.51 \\
0.01 \\
0.01 \\
0.12\end{array}$ & $\begin{array}{r}74.70 \\
13.87 \\
0.39 \\
0.19 \\
0.72 \\
3.87 \\
4.65 \\
0.03 \\
0.02 \\
0.01\end{array}$ & $\begin{array}{r}74.49 \\
13.85 \\
1.03 \\
0.20 \\
0.63 \\
3.59 \\
4.96 \\
0.07 \\
0.01 \\
0.02\end{array}$ & $\begin{array}{r}75.56 \\
12.25 \\
1.59 \\
0.17 \\
0.45 \\
3.88 \\
5.00 \\
0.10 \\
0 \\
0.04\end{array}$ \\
\hline (ppm) & & & & & & & \\
\hline $\mathrm{Ba}$ & 112 & 91 & 94 & 134 & 450 & 245 & 215 \\
\hline $\mathrm{Cr}$ & 128 & 142 & 153 & 148 & 158 & 136 & 197 \\
\hline $\mathbf{Z r}$ & 30 & 35 & 25 & 40 & 83 & 101 & 162 \\
\hline Sr & 10 & 20 & 24 & 61 & 145 & 38 & 15 \\
\hline $\mathbf{R b}$ & 194 & 100 & 101 & 94 & 114 & 197 & 90 \\
\hline $\mathbf{Y}$ & 16 & 86 & 80 & 27 & 153 & 77 & 30 \\
\hline $\mathbf{N b}$ & 6 & $\therefore$ & - & - & - & 32 & 9 \\
\hline $\mathbf{Z n}$ & 13 & 25 & 7 & 21 & 10 & 30 & 46 \\
\hline $\mathbf{N i}$ & - & - & - & - & 7 & - & - \\
\hline $\mathbf{V}$ & - & 6 & - & - & $\cdot$ & - & - \\
\hline
\end{tabular}

$\begin{array}{llllllll}\text { TOTAL } & 100.23 & 99.88 & 98.99 & 98.79 & 98.59 & 98.95 & 99.15\end{array}$

CIPW

$\begin{array}{lccccccc}\text { Q } & 34.38 & 32.84 & 32.49 & 32.04 & 33.11 & 33.36 & 42.56 \\ \text { Or } & 25.65 & 24.52 & 24.74 & 27.02 & 27.93 & 29.67 & 31.17 \\ \text { Ab } & 34.80 & 35.50 & 35.14 & 33.76 & 33.25 & 30.72 & 20.91 \\ \text { An } & 1.74 & 3.07 & 3.71 & 3.15 & 3.49 & 3.09 & 0.87 \\ \text { C } & 2.27 & 2.18 & 2.11 & 2.50 & - & 1.47 & 0.32 \\ \text { Di } & - & - & - & - & - & - & - \\ \text { Hy } & - & - & - & 0.43 & 0.48 & 0.50 & 0.15 \\ \text { Mt } & 0.23 & 0.98 & 0.99 & 0.33 & - & - & 2.43 \\ \text { Il } & 0.02 & 0.02 & 0.01 & 0.02 & - & 0.02 & 0.36 \\ \text { Ap } & 0.07 & 0.09 & - & 0.02 & 0.05 & 0.02 & - \\ \text { Rb/Sr } & 7.18 & 5.00 & 4.40 & 1.57 & 0.79 & 5.19 & 6.52 \\ \text { DI } & 94.83 & 92.86 & 92.37 & 92.82 & 94.29 & 93.76 & 94.63\end{array}$




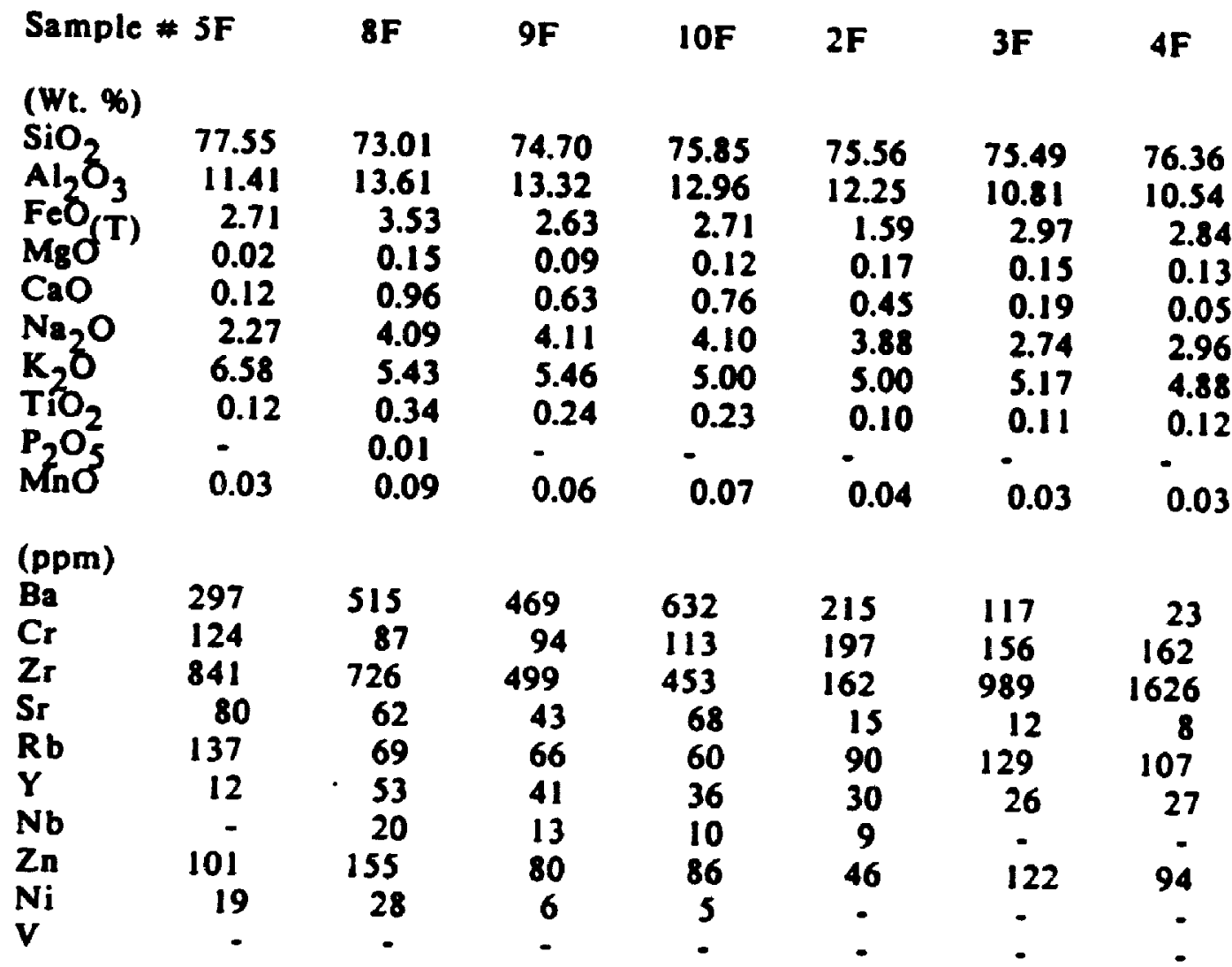

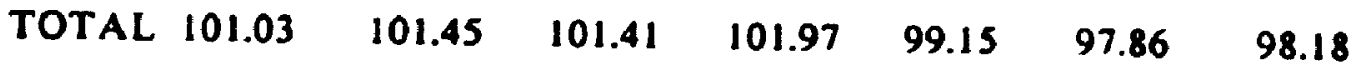
CIPW

$\begin{array}{lccccccc}\text { Q } & 38.46 & 25.95 & 28.36 & 30.85 & 33.14 & 39.76 & 40.82 \\ \text { Or } & 38.64 & 31.78 & 31.93 & 29.08 & 29.85 & 31.35 & 29.52 \\ \text { Ab } & 19.07 & 34.24 & 34.38 & 34.11 & 33.14 & 23.77 & 25.61 \\ \text { An } & 0.59 & 2.70 & 1.74 & 2.14 & 1.24 & 0.97 & 0.25 \\ \text { C } & 0.33 & - & - & - & - & 0.37 & 0.30 \\ \text { Di } & - & 0.58 & 0.48 & 0.63 & 0.79 & - & - \\ \text { Hy } & 0.28 & 0.32 & - & - & - & 0.43 & 0.83 \\ \text { Mt } & 2.33 & 2.64 & 2.01 & 2.31 & - & 2.39 & 2.40 \\ \text { II } & 0.23 & 0.64 & 0.45 & 0.43 & 0.06 & 0.21 & 0.23 \\ \text { Ap } & - & 0.02 & - & - & - & - & - \\ \text { Rb/Sr } & 1.72 & 1.13 & 1.58 & 0.89 & 6.42 & 10.76 & 15.33 \\ \text { DI } & 96.18 & 91.98 & 94.66 & 94.04 & 96.13 & 94.88 & 95.94\end{array}$




\begin{tabular}{lcc} 
Sample * & \multicolumn{1}{c}{ IIF } \\
(Wt. \%) & & \\
$\mathrm{SiO}_{2}$ & 73.47 & 75.27 \\
$\mathrm{Al}_{2} \mathrm{O}_{3}$ & 12.83 & 12.25 \\
$\left.\mathrm{FeO}_{\mathrm{f}} \mathrm{T}\right)$ & 2.91 & 2.19 \\
$\mathrm{MgO}$ & 0.16 & 0.15 \\
$\mathrm{CaO}$ & 0.49 & 0.42 \\
$\mathrm{Na}_{2} \mathrm{O}$ & 3.15 & 3.41 \\
$\mathrm{~K}_{2} \mathrm{O}$ & 5.63 & 5.30 \\
$\mathrm{TiO}_{2}$ & 0.20 & 0.12 \\
$\mathrm{P}_{2} \mathrm{O}_{5}$ & - & - \\
$\mathrm{MnO}$ & 0.06 & 0.03 \\
& & \\
$(\mathrm{ppm})$ & & \\
$\mathrm{Ba}$ & 443 & 247 \\
$\mathrm{Cr}$ & 145 & 186 \\
$\mathrm{Zr}$ & 513 & 315 \\
$\mathrm{Sr}$ & 54 & 28 \\
$\mathrm{Rb}$ & 77 & 86 \\
$\mathrm{Y}$ & 35 & 45 \\
$\mathrm{Nb}$ & 3 & 3 \\
$\mathrm{Zn}$ & 59 & 76 \\
$\mathrm{Ni}$ & - & - \\
$\mathrm{V}$ & 2 & -
\end{tabular}

TOTAL $\quad 99.06 \quad 99.26$

\section{CIPW}

$Q$

$32.53 \quad 34.31$

$\begin{array}{lll}\text { Or } & 33.71 & 3.1 .63\end{array}$

Ab $\quad 26.98 \quad 29.11$

An $\quad 2.46 \quad 2.10$

$\begin{array}{lll}\text { C } & 0.67 & 0.14\end{array}$

$\mathrm{Di} \quad-\quad$ -

$\begin{array}{lll}\text { Hy } & 0.74 & 0.38\end{array}$

$\begin{array}{lll}\text { Mt } & 2.50 & 1.36\end{array}$

$\begin{array}{lll}\text { II } & 0.39 & 0.23\end{array}$

Ap

$\begin{array}{lll}\mathrm{Rb} / \mathrm{Sr} & 1.42 & 3.06\end{array}$

DI $\quad 93.22 \quad 95.06$ 
TABLE A 2.3

TRACE ELEMENT DATA

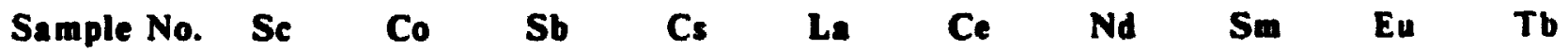
$\begin{array}{lllllllllll}\text { T4D } & 19.9 & 29 & 0.08 & 0.83 & 14.7 & 31 & 15.9 & 3.7 & 1.15 & 0.55\end{array}$ $\begin{array}{lllllllllll}\text { TIA } & 2.8 & 2.4 & 0.1 & 0.27 & 9.6 & 17.2 & 7.5 & 1.44 & 0.46 & 0.18\end{array}$ $\begin{array}{lllllllllll}\text { T3G } & 16.9 & 15.4 & 0.11 & 1.59 & 19.2 & 41 & 22 & 4.8 & 1.23 & 0.75\end{array}$ $\begin{array}{lllllllllll}\text { TIH } & 18 & 17.8 & 0.20 & 0.85 & 23 & 50 & 25 & 5.4 & 1.47 & 0.80\end{array}$

$\begin{array}{lllllllllll}\text { T111 } & 16.3 & 13.2 & 0.42 & 2.5 & 24 & 53 & 25 & 5.1 & 1.17 & 0.85\end{array}$

$\begin{array}{lllllllllll}\text { T6J } & 6.8 & 4 & 0.15 & 0.84 & 25 & 50 & 23 & 4.6 & 1.20 & 0.70\end{array}$

$\begin{array}{lllllllllll}\text { T4M } & 7.8 & 0.32 & 0.1 & 1.80 & 15.7 & 29 & 12.5 & 2.4 & 0.22 & 0.56\end{array}$

$\begin{array}{lllllllllll}\text { T8F } & 4.1 & 1.11 & 0.1 & 0.2 & 104 & 215 & 96 & 17.4 & 1.68 & 2.4\end{array}$

$\begin{array}{lllllllllll}\text { T9O } & 7.2 & 4.3 & 0.08 & 1.57 & 68 & 142 & 59 & 11.3 & 1.65 & 1.86\end{array}$

$\begin{array}{lllllllllll}\text { T8K } & 1.21 & 0.69 & 0.09 & 0.83 & 51 & 120 & 57 & 11.4 & 0.75 & 1.60\end{array}$

$\begin{array}{lllllllllll}\text { T8L } & 10.3 & 7.4 & 0.17 & 1.32 & 103 & 224 & 100 & 18.5 & 2.6 & 2.8\end{array}$

Sample No. Dy Ho Er Yb Lu Hf Ta w

$\begin{array}{lcccccccccc}\text { T4D } & 3.7 & 0.72 & 1.6 & 1.70 & 0.29 & 2.6 & 0.60 & 2 & 2.8 & 1.06 \\ \text { TIA } & 1.4 & 0.18 & 0.72 & 0.60 & 0.10 & 2.3 & 0.28 & 2 & 1.5 & 0.27 \\ \text { T3G } & 4.5 & 0.79 & 2.8 & 2.3 & 0.39 & 4.3 & 0.34 & 2 & 1.16 & 0.58 \\ \text { TIH } & 4.4 & 0.82 & 2.3 & 1.94 & 0.32 & 4.1 & 0.50 & 2 & 1.25 & 0.68 \\ \text { TIII } & 5.5 & 0.98 & 2.4 & 2.7 & 0.47 & 5.4 & 0.76 & 2 & 5.9 & 2.1 \\ \text { T6J } & 4.0 & 0.83 & 1.9 & 2.7 & 0.44 & 6.7 & 0.92 & 2 & 3.8 & 1.59 \\ \text { T4M } & 4.6 & 1.13 & 3.3 & 4.3 & 0.72 & 2.3 & 0.43 & 2 & 4.1 & 1.60 \\ \text { T8F } & 12.3 & 2.1 & 5.3 & 5.7 & 0.98 & 15.6 & 1.28 & 2 & 12.4 & 1.82 \\ \text { T90 } & 10.7 & 2.16 & 5.1 & 5.6 & 0.91 & 10.2 & 3 & 2 & 18.2 & 2.9 \\ \text { T8K } & 8.6 & 1.74 & 4 & 4.4 & 0.70 & 7.1 & 1.52 & 2 & 10.6 & 2.6 \\ \text { T8L } & 14.7 & 2.9 & 7.3 & 7.6 & 1.22 & 11.1 & 2.2 & 2.5 & 13.2 & 2.9\end{array}$




\section{APPENDIX 3 \\ MICROPROBE ANALYSES OF MINERALS}

BIOTITE

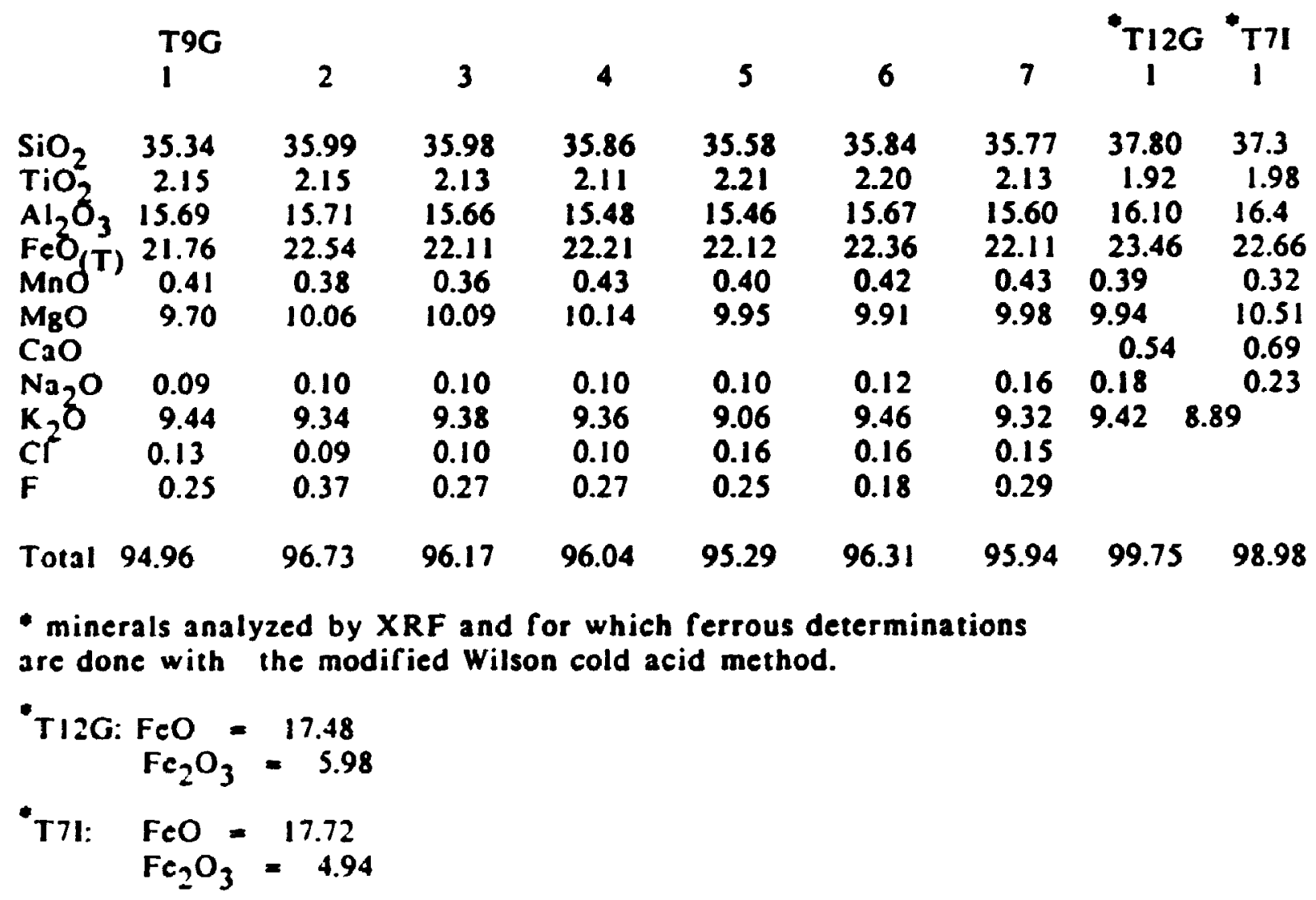


HORNBLENDE

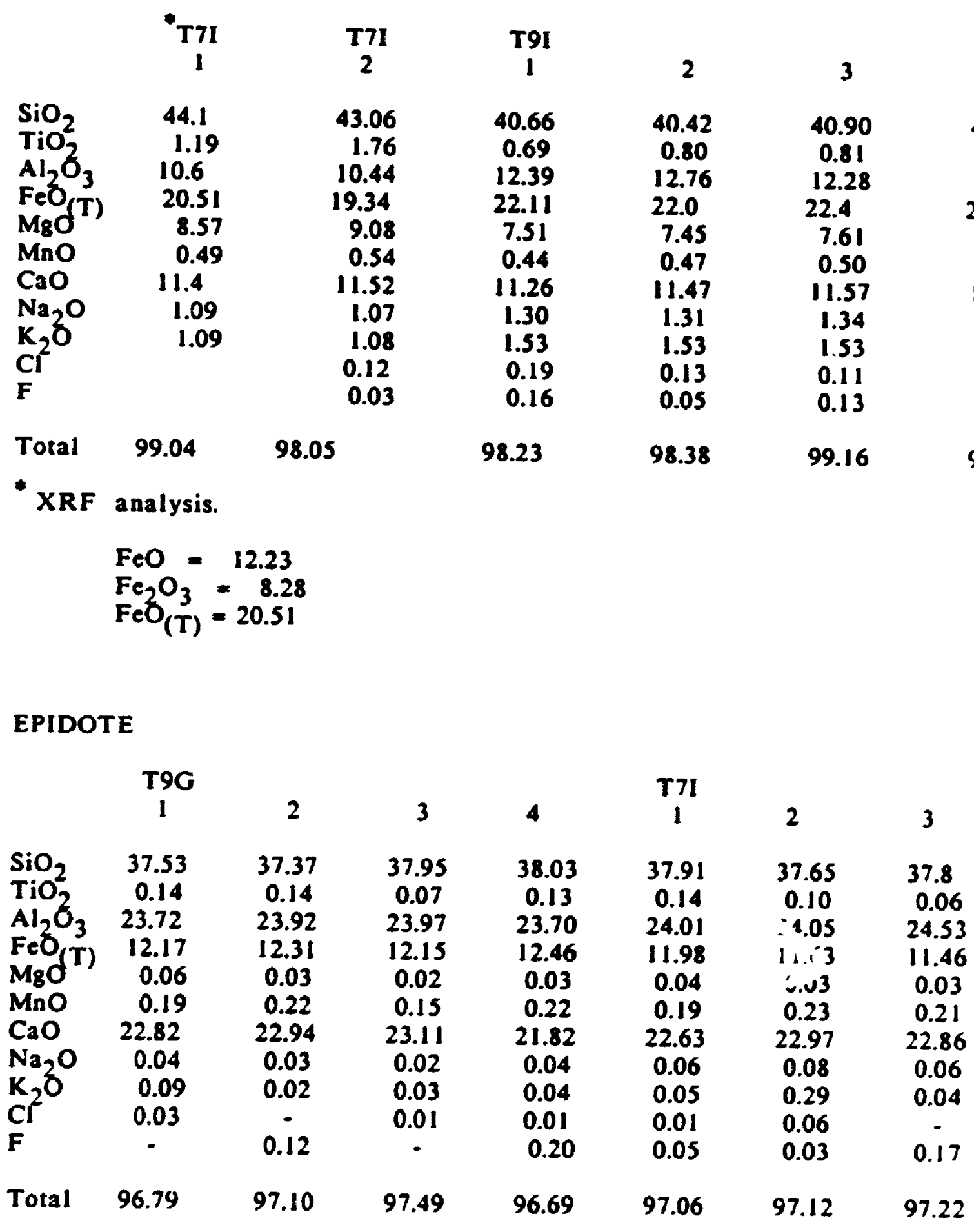


Plagioclase

\begin{tabular}{|c|c|c|c|c|c|c|c|c|}
\hline & $\begin{array}{c}\text { T9G } \\
1\end{array}$ & 2 & 3 & 4 & 5 & 6 & 7 & 8 \\
\hline $\begin{array}{l}\mathrm{SiO}_{2} \\
\mathrm{Al}_{2} \mathrm{O} \\
\mathrm{CaO}_{3} \\
\mathrm{Na}_{2} \mathrm{O} \\
\mathrm{K}_{2} \mathrm{O}\end{array}$ & $\begin{array}{c}59.45 \\
25.71 \\
7.34 \\
7.41 \\
0.16\end{array}$ & $\begin{array}{c}59.28 \\
24.98 \\
6.78 \\
7.60 \\
0.15\end{array}$ & $\begin{array}{c}59.18 \\
25.75 \\
7.44 \\
7.31 \\
0.19\end{array}$ & $\begin{array}{c}59.35 \\
25.20 \\
6.94 \\
7.52 \\
0.19\end{array}$ & $\begin{array}{c}59.34 \\
25.58 \\
7.26 \\
7.46 \\
0.10\end{array}$ & $\begin{array}{l}59.73 \\
25.48 \\
7.08 \\
7.3 \\
0.19\end{array}$ & $\begin{array}{l}59.95 \\
25.15 \\
6.76 \\
7.75 \\
0.10\end{array}$ & $\begin{array}{l}59.09 \\
25.34 \\
7.12 \\
7.49 \\
0.08\end{array}$ \\
\hline Total & 100.08 & 98.78 & 99.87 & 99.20 & 99.75 & 100.02 & 99.72 & 99.11 \\
\hline
\end{tabular}

Plagioclase

T9G

9

$\begin{array}{lr}\mathrm{SiO}_{2} & 59.47 \\ \mathrm{Al}_{2} \mathrm{O}_{3} & 25.22 \\ \mathrm{CaO}^{2} & 6.93 \\ \mathrm{Na}_{2} \mathrm{O} & 7.56 \\ \mathrm{~K}_{2} \mathrm{O} & 0.17\end{array}$

Total $\quad 99.36$
10

59.31

25.47

7.18

7.46

0.15
11

59.96

25.77

7.27

7.58

0.08

$99.57 \quad 100.06$

Plagioclase

12

59.07
25.36

7.14

7.44

0.14
T71

60.83
24.61
6.11
8.21

$99.14 \quad 99.75$

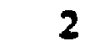

3

4

$\begin{array}{ccc}58.07 & 59.52 & 59.42 \\ 26.14 & 25.86 & 25.10 \\ 8.02 & 7.45 & 6.85 \\ 7.02 & 7.49 & 7.70\end{array}$

99.24

100.32

99.06

MICROCLINE

T7I

5

6

T7M

$\begin{array}{lcccccccc} & 5 & 6 & 1 & 2 & 3 & 4 & 1 & 2 \\ \mathrm{SiO}_{2} & 59.34 & 54.09 & 64.53 & 64.70 & 65.97 & 65.84 & 64.19 & 64.48 \\ \mathrm{Al}_{2} \mathrm{O}_{3} & 25.15 & 27.50 & 21.67 & 21.53 & 22.13 & 21.75 & 18.22 & 18.23 \\ \mathrm{CaO}_{3} & 6.90 & 10.07 & 2.82 & 2.67 & 2.86 & 2.58 & 0.05 & - \\ \mathrm{Na}_{2} \mathrm{O} & 7.66 & 5.58 & 10.07 & 10.15 & 10.07 & 10.21 & 1.06 & 0.80 \\ \mathrm{~K}_{2} \mathrm{O} & & & & & 0.34 & 0.26 & 15.12 & 15.64\end{array}$

Total $\quad 99.05 \quad 97.24$

99.09

$99.05 \quad 101.38$

100.65

98.64

99.15

MICROCLINE

T7M

3
4

64.35

18.24

0.03

0.81

15.56

98.99

\section{Plagioclase}

T8F

$8 F$

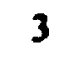

\subsection{1}

19.74

0.23

11.63

0.16

67.83

20.08

0.74

11.29

0.14

$100.57 \quad 100.08$
66.21

20.5

1.47

10.75

0.17

99.
4
67.05
20.75
1.47
10.90
0.17

$\begin{array}{lll}99.1 & 100.34 & 100.29\end{array}$

\section{6}

$\begin{array}{cc}67.25 & 66.96 \\ 20.61 & 21.09 \\ 1.31 & 1.78 \\ 10.99 & 10.79 \\ 0.12 & 0.12\end{array}$

Tolal 98.86

100.75 
MICROCLINE

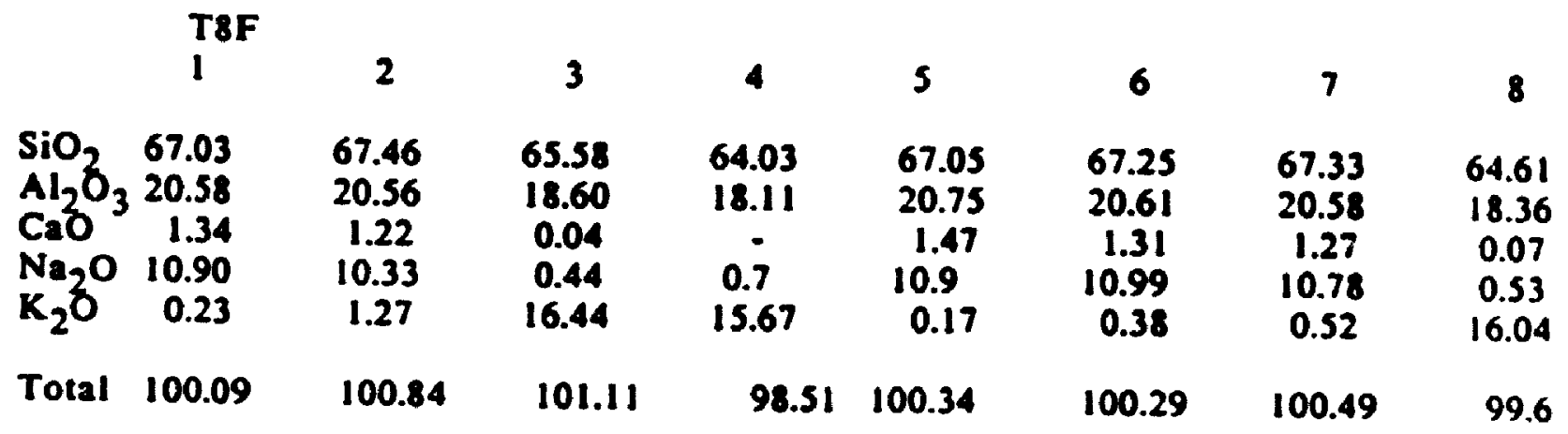

PLAgioclase

MICROCLINE

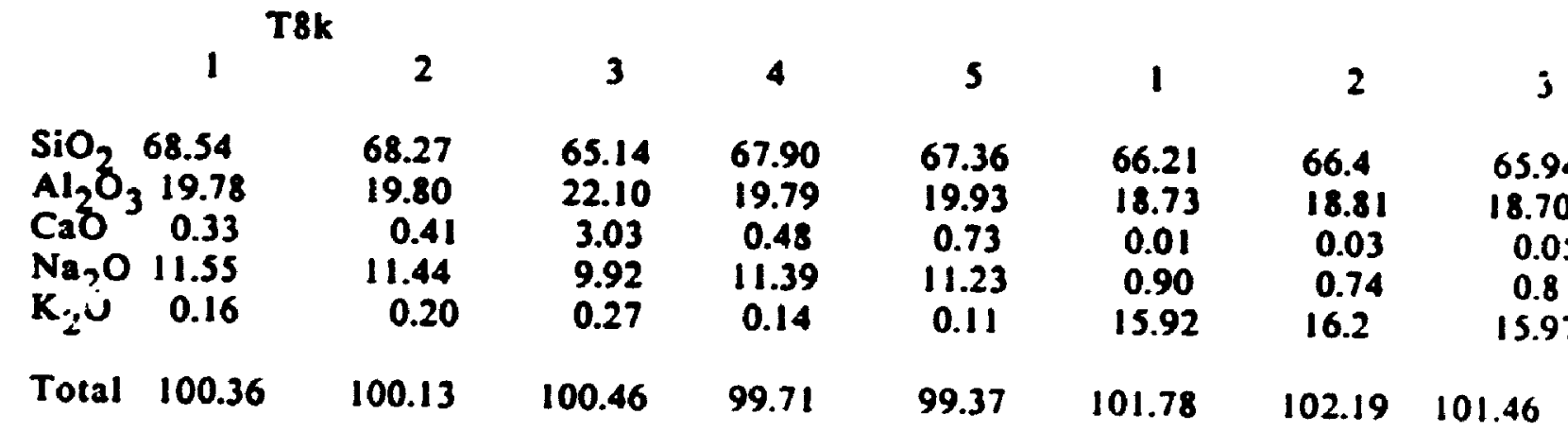

MICROCLINE

T8K 45

$\begin{array}{lcc}\mathrm{SiO}_{2} & 65.77 & 65.36 \\ \mathrm{Al}_{2} \mathrm{O}_{3} & 18.72 & 18.48 \\ \mathrm{CaO}_{2} & 0.10 & - \\ \mathrm{Na}_{2} \mathrm{O} & 0.68 & 0.59 \\ \mathrm{~K}_{2} \mathrm{O} & 16.10 & 16.19\end{array}$

Total $\quad 101.36 \quad 100.61$ 


\section{MUSCOVITE}

T7M

12

GARNET

$\begin{array}{cc}3 & 4 \\ 45.23 & 45.76 \\ 33.06 & 32.13 \\ 4.36 & 4.28 \\ 0.54 & 0.52 \\ - & - \\ 0.03 & - \\ 0.41 & 0.27 \\ 10.36 & 11.0 \\ 0.24 & -\end{array}$

94.27

93.96

94.21

$\begin{array}{ccc}46.08 & 36.29 & 36.32 \\ 31.65 & 20.83 & 20.83 \\ 4.70 & 25.61 & 25.83 \\ 0.50 & 1.21 & 1.24 \\ - & 0.84 & 0.89 \\ -. & 14.86 & 14.75 \\ 0.17 & - & - \\ 11.11 & - & - \\ - & - & -\end{array}$

Total 94.65

94.81

APATITE

T9G

1

2

3

$\mathrm{CaO}$
$\mathrm{P}_{2} \mathrm{O}_{5}$

55.34
42.58
0.10
3.49

55.37

42.71

0.13

3.48

53.99

41.75

0.08

3.27

Total

101.51

101.69

99.09 


\section{APPENDIX}

\section{U-Pb ANALYTICAL METHODS}

U-Pb zircon geochronology laboratory procedures employed at the geochronology laboratory of the Geological Survey of Canada are given in Parrish et al. (1987). These include mineral preparation and selection, addition of tracer (spiking), chemical dissolution, chemical separation and purification, mass spectrometry, crror analysis, and linear regressions.

Zircons were separated from 1-2 $\mathrm{kg}$ specimens by standard crushing. grinding. heavy liquid, and magnetic separator, followed by sieving in ethyl alcohol into a number of size fractions. All minerals were selected for analysis by handpicking in ethyl alcohol. The criteria used in mineral selectior, pastirularly zircon, optimize the clarity and diagnostic morphology of the crystals. the lack of cracks and inclusions, and the general absence of cored grains unless these are specifically of interest. A portion of some zircon mineral separales was mounted in FEP Teflon or epoxy grain mounts, polished to an optical finish, and etched in HF vapour to reveal details of the internal structure. Optical microscopy, photomicrography, and scanning electron phntomicrography were utilized to observe the morphological aspects which assist in the interpretation of U-Pb zircon results. The zircon fractions were then air abraded following the technique of Krogh (1982) using pyrite as a medium in the abrasion cells. Abraded zircons were leached 15 minutes in luke warm $3 \mathrm{~N} \mathrm{HNO}_{3}$ lo remove abrasion residues prior to the final mineral selection stage. 
The clean chemistry laboratory for $\mathrm{U}-\mathrm{Pb}$ has a source of high efricicncy particulate filtered air. Critical chemical work and weighing was done in specially designed, mainly polypropylene, hoods with their own separate source of the high efficiency particulate air filtered room. Laboratory air is not recirculated, and the laboratory has a minimum of exposed metal. Minerals are weighed using aluminim boats in a micro-balance which has a quoted precision of $+/-0.2$ micrograms. In practice when weighing samples, experience indicates the uncertainity to be $+/-0.5-1.0$ micrograms. Tracer solution is dispensed into Teflon dissolution crucibles and weighed by difference using $a$ balance which has a quoted precision of $t /-0.02$ mg. Following chemical separation and purification, $P b$ and $U$ solutions are collected and evaporated in $30 \mathrm{ml}$ polymethylpentene beakers. The collection beakers are pre-cleaned by boiling in reagent grade $6 \mathrm{~N} \mathrm{HCl}$ followed by refluxing for at least $1-2$ hours on a hot plate using $6.8 \mathrm{~N} \mathrm{HCl}$ which was double distilled in a quartz sub-boiling still.

Zircon is dissolved in 0.1 to $0.5 \mathrm{ml}$ of high purity $48 \% \mathrm{HF}$ and 0.01 : I of high purity $70 \% \mathrm{HNO}_{3}$ are added; capsules are ihen sealed and heated in an oven at $230-240^{\circ} \mathrm{C}$ for $30-60$ hours. Following dissolution is evaporation to fluorides and the salts are dissolved by heating in an oven at $210^{\circ} \mathrm{C}$ overnight. Subsequent element separation employs $3.1 \mathrm{~N} \mathrm{HCl}$ anion exchange resin column chemistry outlined by Roddick et al.1987. Isotopic composition of $\mathrm{Pb}$ and $\mathrm{U}$ are measured on a Finnigan-MAT 261 variable multicollector mass spectrometer in the static mode as described by Roddick et al. 1987. Roddick (1987) has 
detailed a numerical procedure for propagating the uncertaititics in all the relevant components in the data reduction of the isotupic ratios and ages. Blanks for typical sample amounts of 0.01 to $1 \mathrm{mg}$ are less than $10 \mathrm{Dg} U$ and 6-40 $\mathrm{Pg} \mathrm{Pb}$. Discordant $\mathrm{U}-\mathrm{Pb}$ results are assessed on concordia plots using regression techniques. Criteria for assigning a U-Pb age in the case of zircon inheritance with scattered data arc based on the convergence of data of nearly concordant analyses near the lower intercept of the concordia curve; otherwise linear regression is used on data with least inheritance or where very nearly concordant relative to other data and defines the lower intercept. 
APPENDIX 5

Rb-Sr ANALYTICAL METHODS

\section{A5.1 DISSOLUTION AND PREPARATION OF THE WHOLE-ROCK POWDERS FOR Rb-Sr GEOCHRONOLOGY}

$\mathrm{Rb}$ and $\mathrm{Sr}$ concentrations were determined by $\mathrm{X}_{\mathbf{g}} \mathrm{g}$ y fluoresgence for whole-rock samples, and by isotope dilution using ${ }^{87} \mathrm{Rb}$ and ${ }^{84} \mathrm{Sr}$ spikes for minerals. Separations were carried out by conventional ion exchange techniques as follows:

1) $200 \mathrm{mg}$ of rock powder is taken into solution in a Teflon evaporating dish using $20 \mathrm{ml}$ of $\mathrm{HF}$ and 3-4 drops of $\mathrm{HClO}_{4}$.

2) The sample is taken to dryness on a hot plate at low temperature setting $\left(100^{\circ} \mathrm{C}\right)$.

3) The sample is heated strongly (about $250^{\circ} \mathrm{C}$ ) to drive off any remaining acid.

4) After the dish has cooled, the sample is taken into solution with about $5 \mathrm{ml}$ of $2.5 \mathrm{~N} \mathrm{HCl}$.

5) The sample is taken into solution with $5 \mathrm{ml}$ of $2.5 \mathrm{~N} \mathrm{HCl}$, transferred into a centrifuge tube and is centrifuged for approximately 10 minutes.

6) The solution is then transferred to a disposable beaker and taken to dryness at $100^{\circ} \mathrm{C}$.

7) Then $2 \mathrm{ml}$ of $2.5 \mathrm{~N} \mathrm{HCl}$ is added to the dried sample and the solution is centrifuged again for 10 minutes.

The sample is now ready to be loaded on to the columns.

\section{AS.2 SEPARATION OF Rb AND ST FROM WHOLE-ROCK POWDERS FOR MASS SPECTROMETRY}

Apparatus: Tefion tube $22 \mathrm{~cm}$ in length with an internal diameter of $1.1 \mathrm{~cm}$. Bio-Rad AG50W-X8 cation exchange resin (200-400 mesh, hydrogen form). The resin is equilibrated with $2.5 \mathrm{~N} \mathrm{HCl}$. The columns are packed with $13 \mathrm{ml}$ of the resin, cleaned with $100 \mathrm{ml}$ of $6 \mathrm{~N}$ followed by $2.5 \mathrm{~N}$ HCl. 
8) The prepared sample (after step 7 above) is loaded directly on top of the resin.

9) After the sample is completely absorbed into the resin, it is washed with $5 \mathrm{ml}$ of $2.5 \mathrm{~N} \mathrm{HCl}$ in $1 \mathrm{ml}$ portions to ensure that the sample begins to pass through the res:n.

10) When all of the acid is absorbed, the resin is washed with $30 \mathrm{ml}$ of $2.5 \mathrm{~N} \mathrm{HCl}$ in clean, labelled disposable beakers.

11) $\mathrm{Rb}$ is then collected with $10 \mathrm{ml}$ of $2.5 \mathrm{~N} \mathrm{HCl}$ in clean, labclled disposable beakers.

12) The columns are washed with $25 \mathrm{ml}$ of $2.5 \mathrm{~N} \mathrm{HCl}$.

1:) The $\mathrm{Sr}$ is eluted with $15 \mathrm{ml}$ of $6.2 \mathrm{~N} \mathrm{HCl}$.

14) The resin is then washed with $20 \mathrm{ml}$ of $2.5 \mathrm{~N} \mathrm{HCl}$.

15) The resin is also washed with $15 \mathrm{ml}$ of $6.2 \mathrm{~N} \mathrm{HCl}$.

16) The collected solutions are put on the hot plate.

17) When the $R b$ and $S r$ aliquots are evaporated to $1-2 \mathrm{ml}$, they are transferred into clean, small Tefion dishes and taken to dryness. These samples are now ready $f_{c}$ analyses in the mass spectrometry laboratory.

\section{Summary}

$\begin{array}{lrll}\text { Load sample } & 2 \mathrm{ml} & 2.5 \mathrm{~N} \mathrm{HCl} \\ \text { wash } & 5 \mathrm{ml} & 2.5 \mathrm{~N} \mathrm{HCl} \\ \text { wash } & 30 \mathrm{ml} & 2.5 \mathrm{~N} \mathrm{HCl} \\ \text { collect } & 10 \mathrm{ml} & 2.5 \mathrm{~N} \mathrm{HCl} \mathrm{Rb} \\ \text { wash } & 25 \mathrm{ml} & 2.5 \mathrm{~N} \mathrm{HCl} \\ \text { collect } & 15 \mathrm{ml} & 2.5 \mathrm{~N} \mathrm{HCl} \mathrm{Sr}\end{array}$




\section{AS.3 MASS SPECTROMETRY}

Isotopic analyses were made on a Finnigan-MAT 261 multicollector. solid source mass spectrometer operated in the static mode. The sample is taken into solution with $0.1 \mathrm{ml}$ of high purity doubly distilled water (DDW). This solution is loaded on the outgassed filament for analysis. Sr was loaded with phosphoric acid on a Ta single filament, and $\mathrm{Rb}$ was run as chloride on Re double filaments. Masses ${ }^{86} \mathrm{Sr},{ }^{87} \mathrm{Sr}$ and ${ }^{88} \mathrm{Sr}$ were measured simultaneously on three different channels, and the observed intensities were corrected for the gain of the amplifier and the baseline readings.

A typical analysis, which requires about 60 to 90 minutes, has a 2 sigma of about $0.002 \%$ (Bell et al., 1987). The reproducibilty of the isotopic ratios, estimated on the basis of replicate analyses of samples and chemical standards, is about $+/-0.004 \%$ of the quoted values. The Eimer and Amend $\mathrm{Sr}$ standard gives a value for ${ }^{87} \mathrm{Sr} /{ }^{86} \mathrm{Sr}$ of $0.70802+/-0.00002$; and the NBS $987 \mathrm{Sr}$ standard, $0.71023+/-0.00003$. Sr ratios are normalized to ${ }^{86} \mathrm{Sr} /{ }^{88} \mathrm{Sr}=0.1194$. Blanks for typical analyses averaged $2 \mathrm{ng}$ for $\mathrm{Sr}$, and $0.01 \mathrm{ng}$ for $\mathrm{Rb}$. 

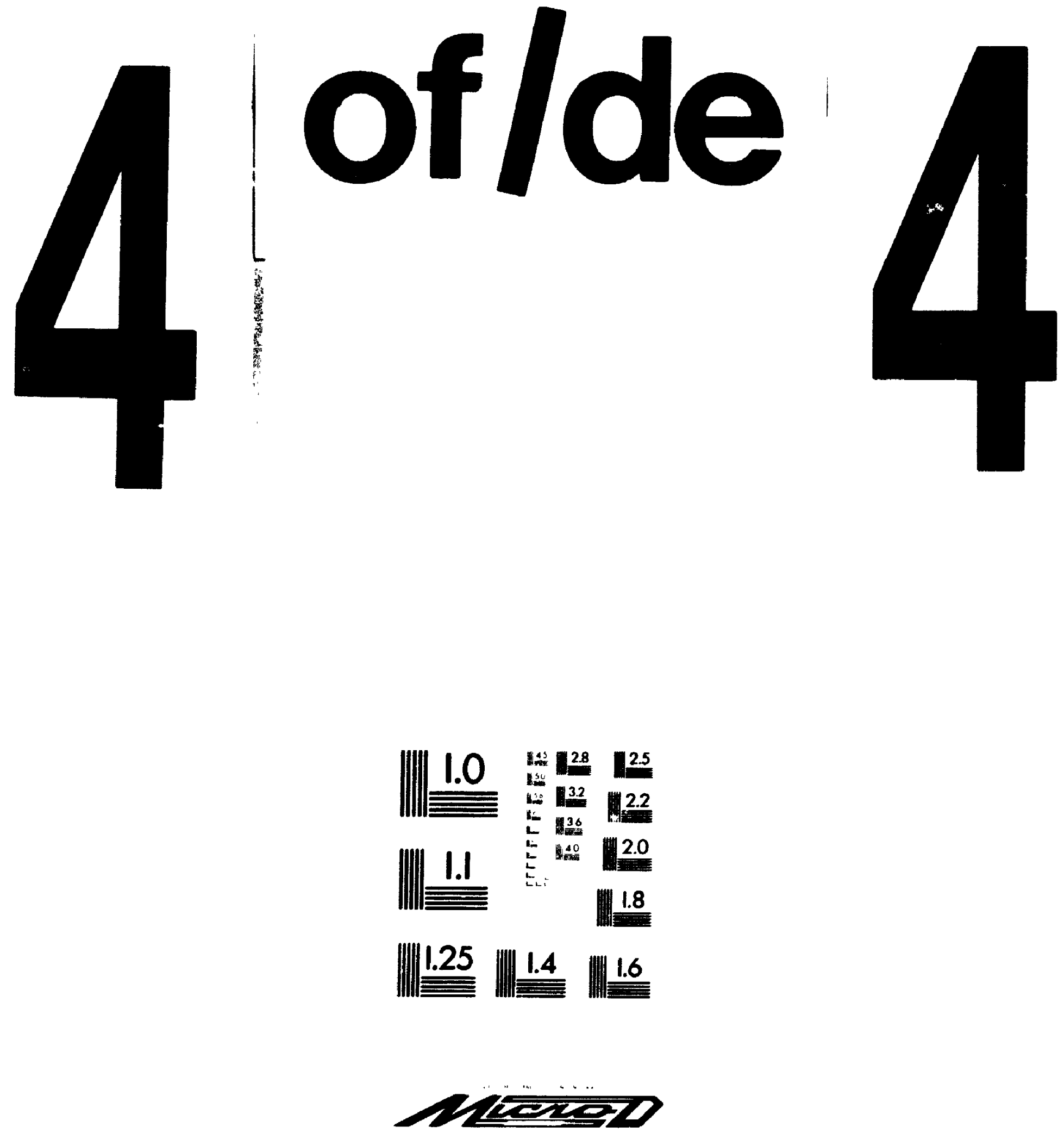


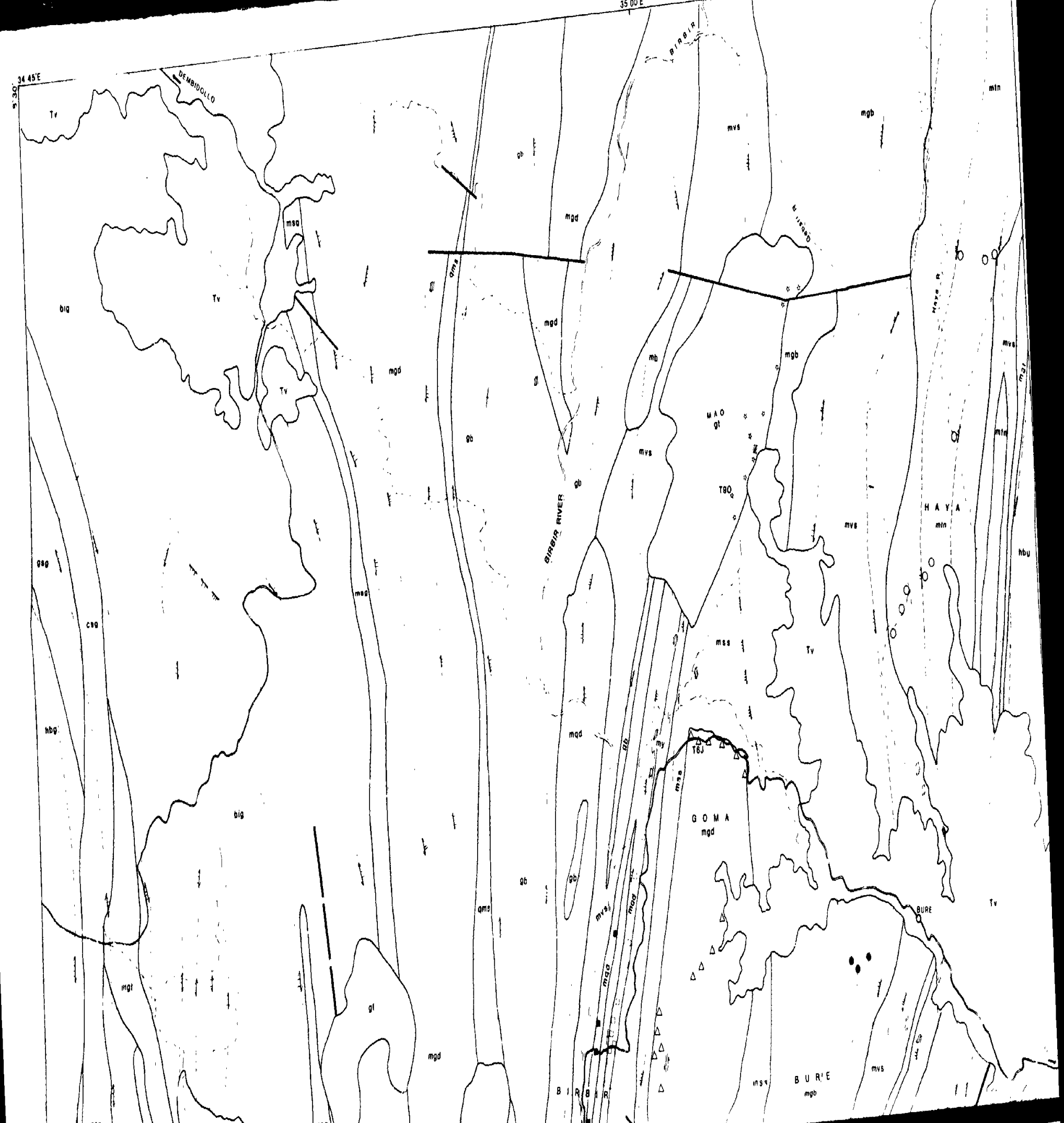



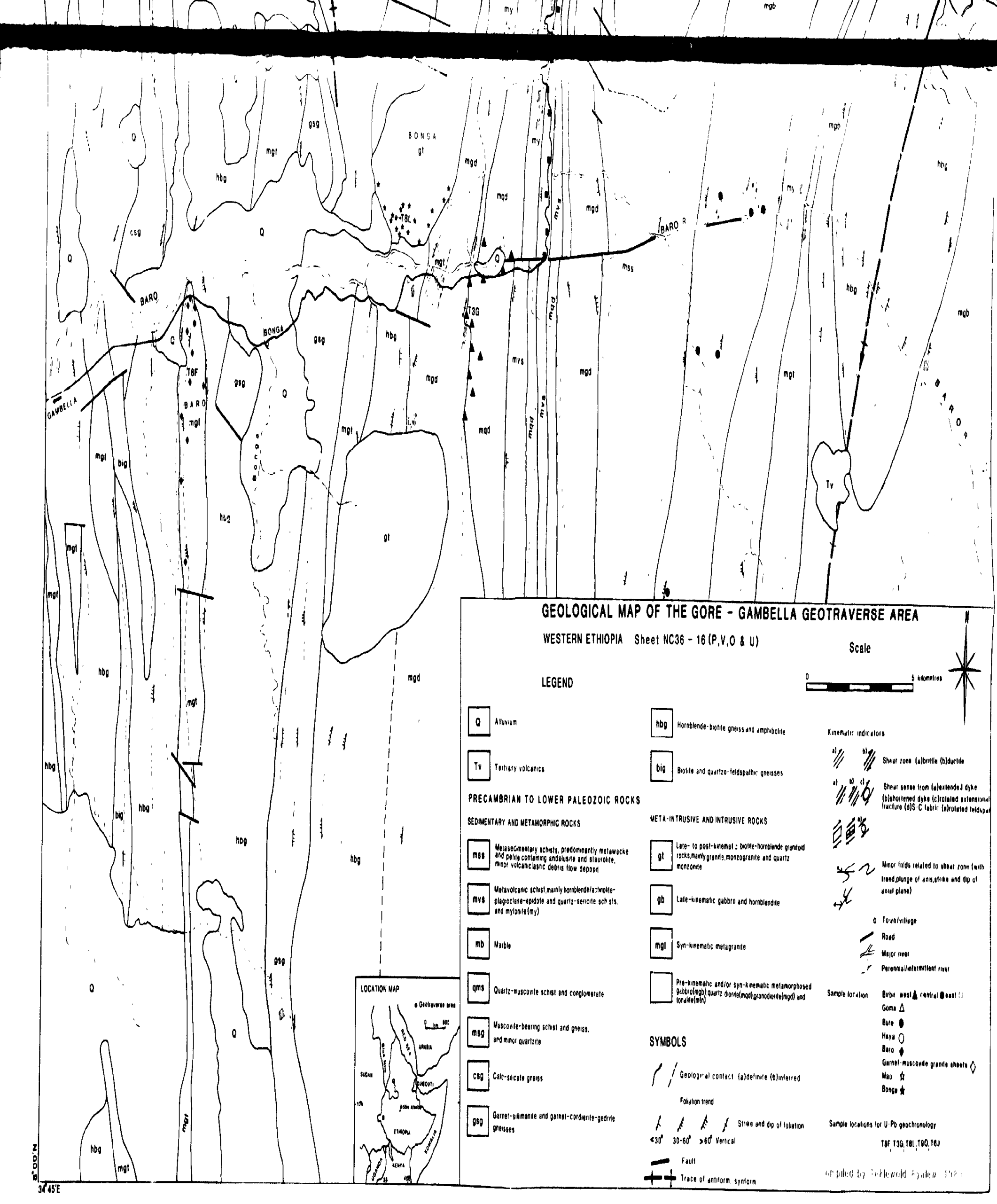


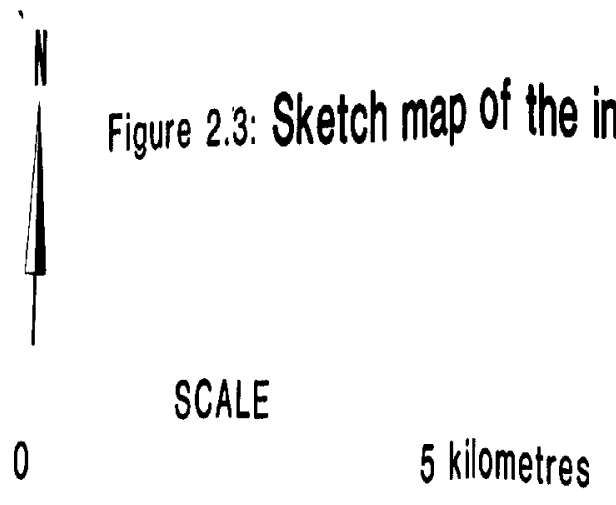

\section{$35^{\circ} \mathrm{E}$}

Figure 2.3: Sketch map of the intrusive units and sample localities

SCALE

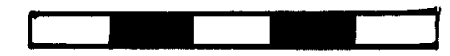




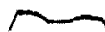
is

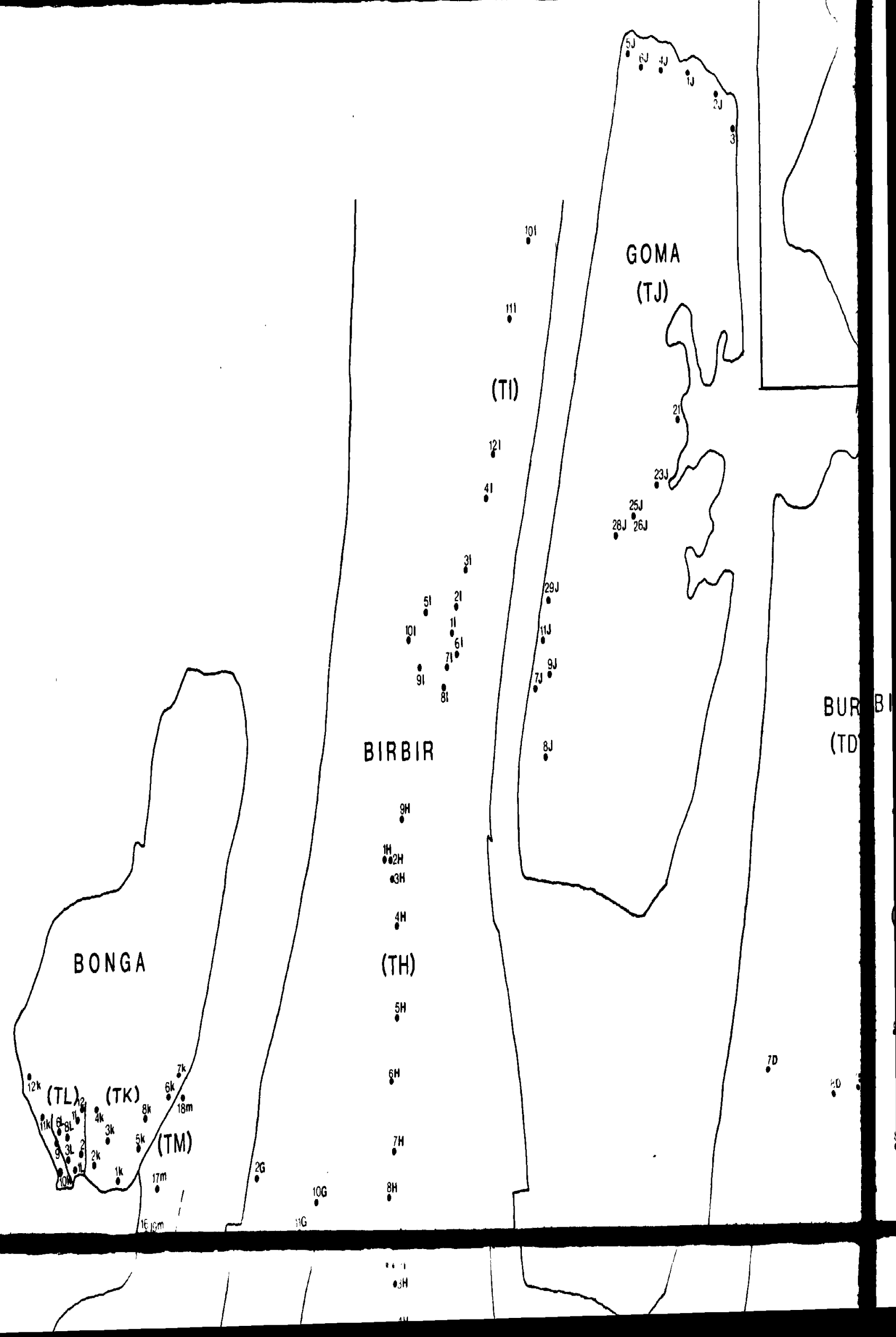



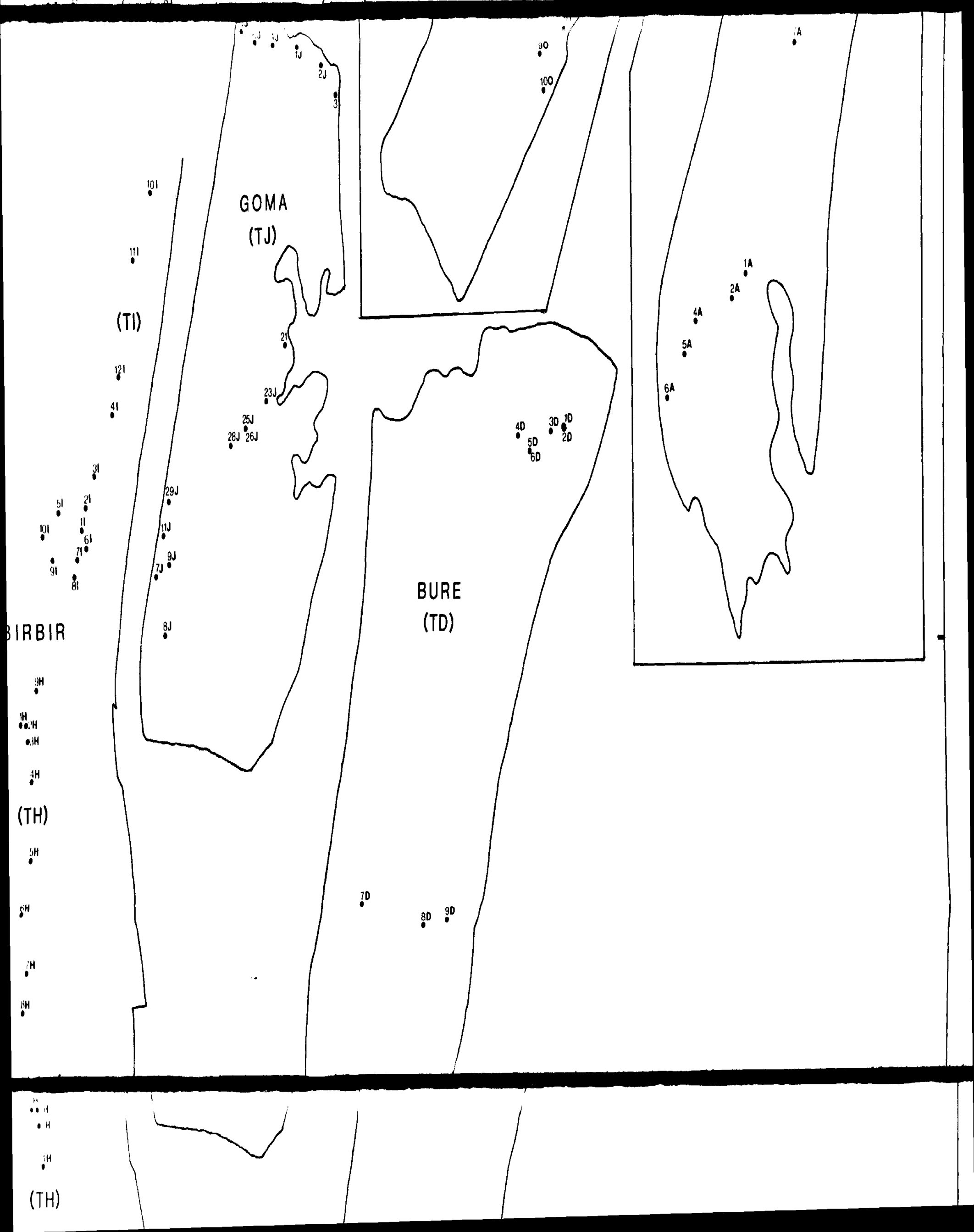


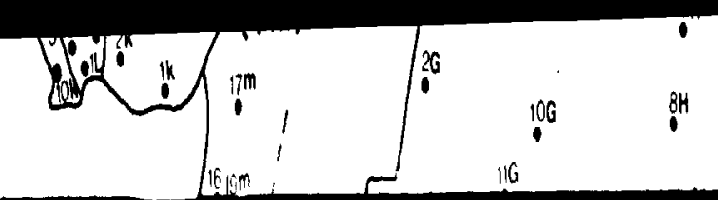



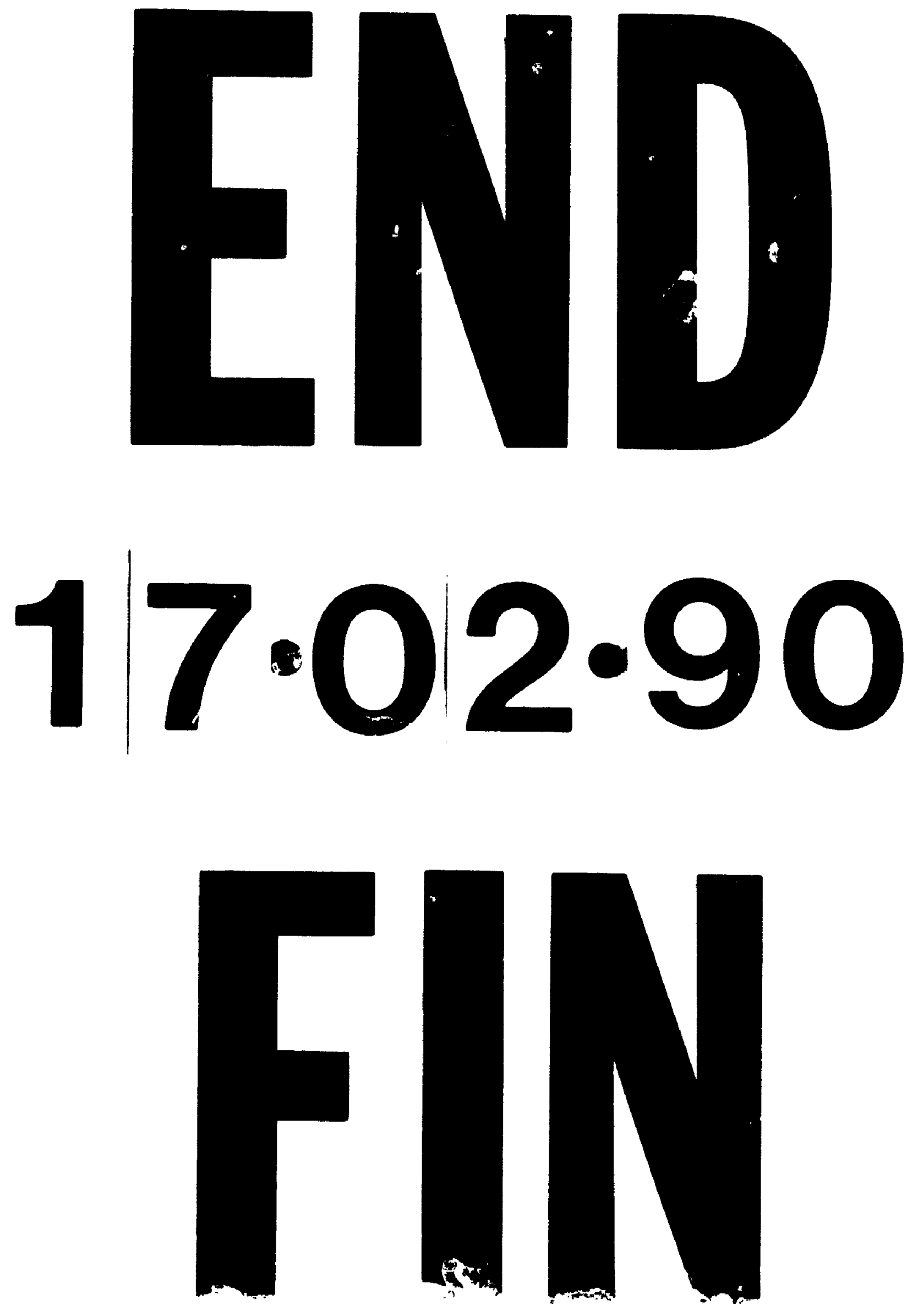